\title{
SMALL
}

FRENCH BUILDINGS LEWIS A.COFHIN, JR, HENRY M.POLHEMUS AND ADDISON E. WORTHINGTON

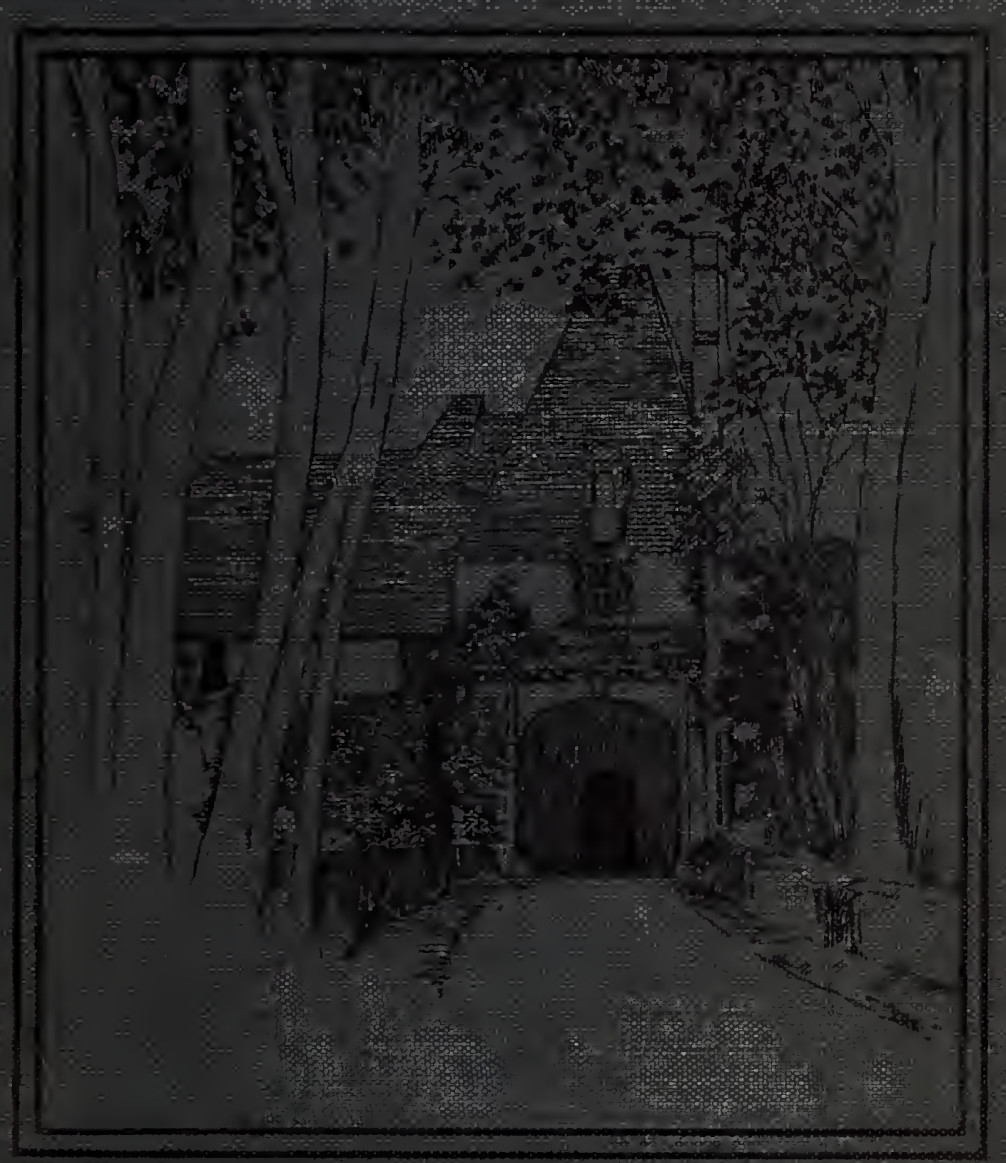


Cooper-Hewitt Museum Library

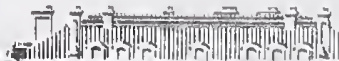

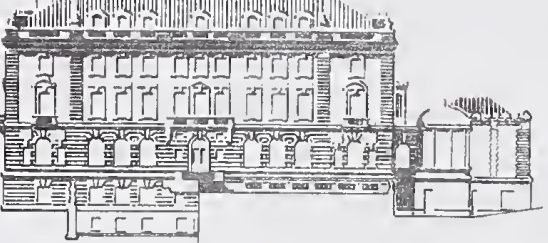



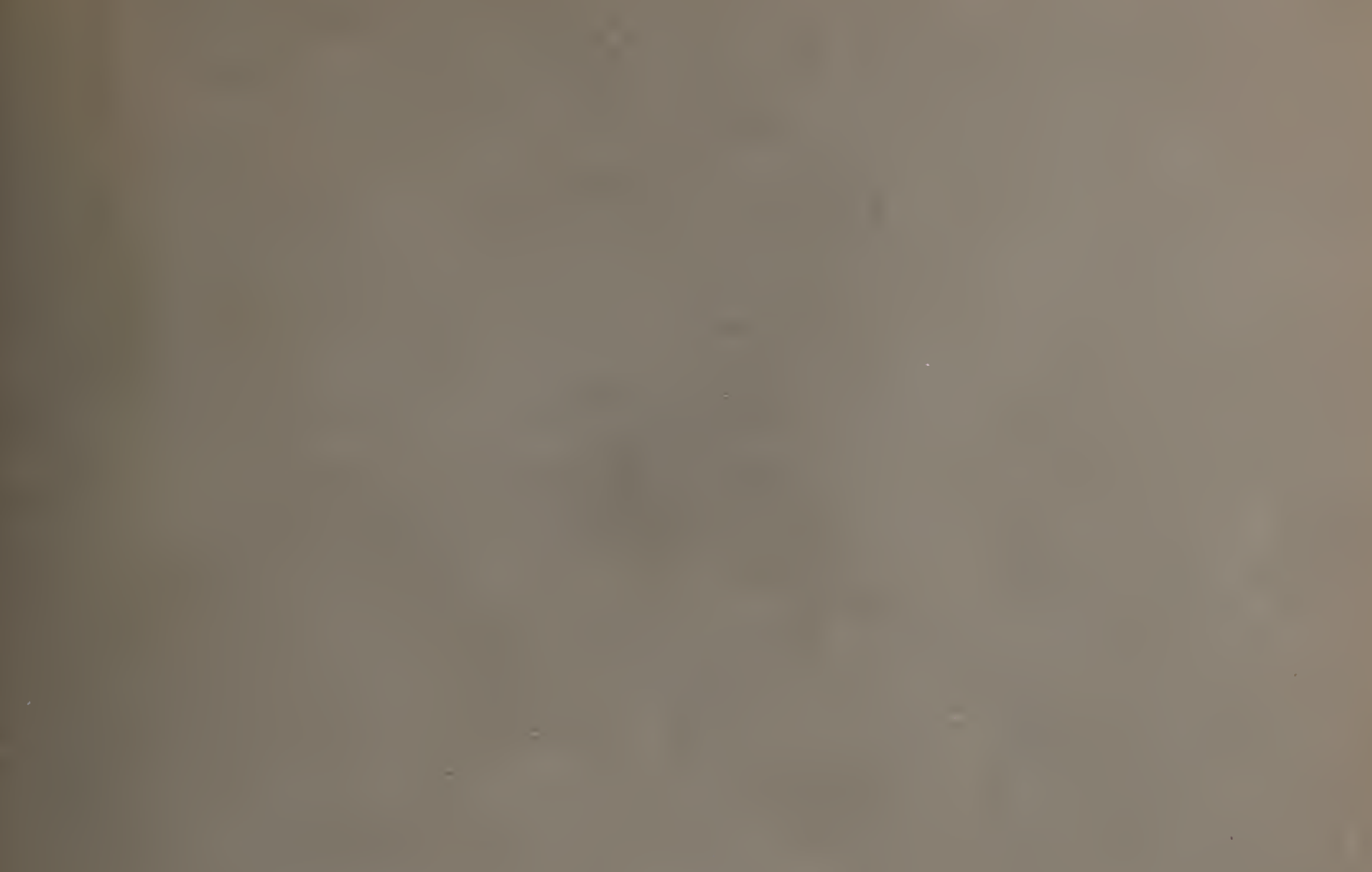

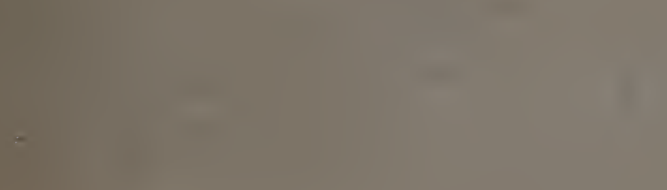



SMALL FRENCH BUILDINGS 




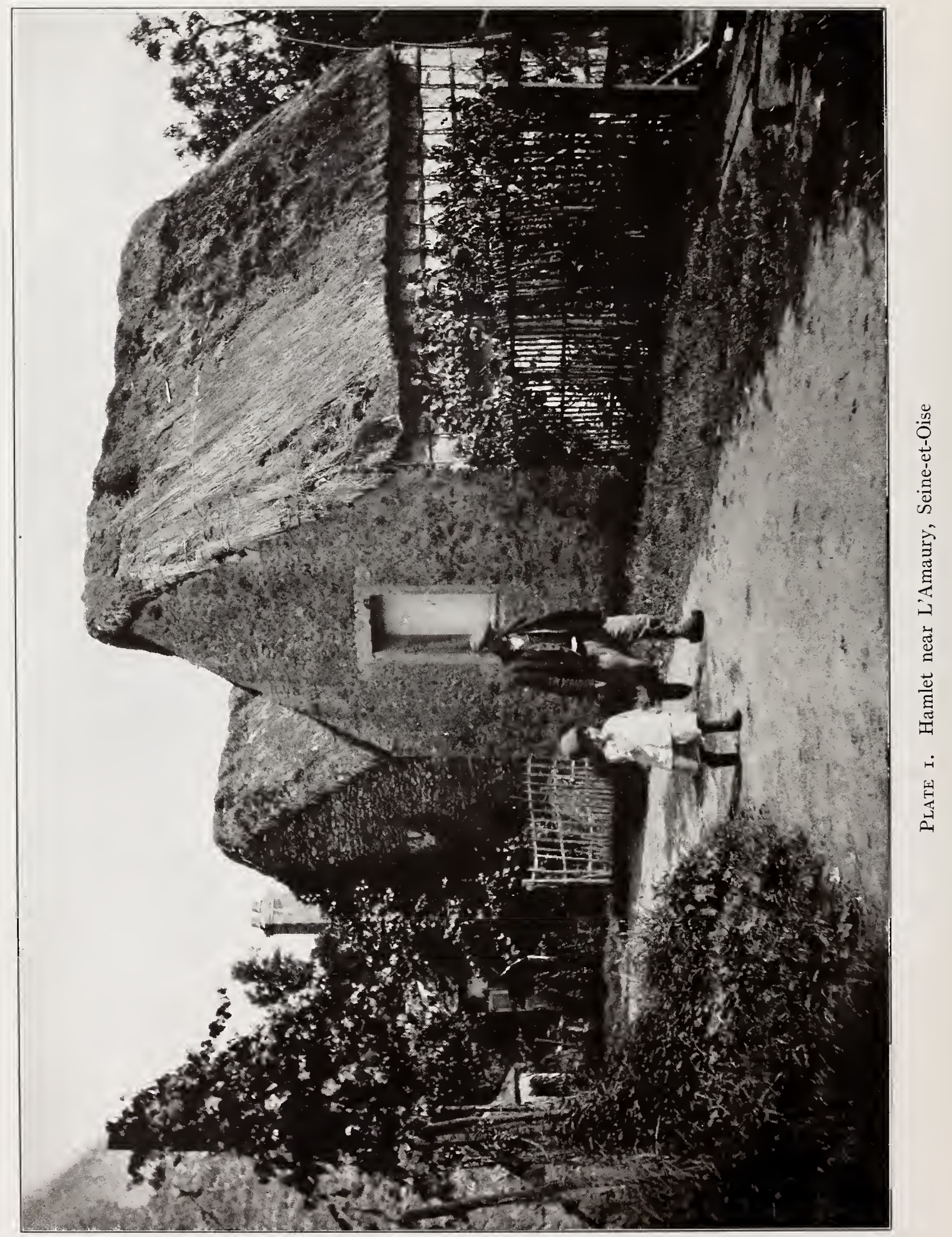




\section{SMALL \\ FRENCH BUILDINGS}

THE ARCHITECTURE OF TOWN AND COUNTRY

COMPRISING COTTAGES, FARMHOUSES, MINOR CHATEAUX OR MANORS

WITH THEIR FARM GROUPS

SMALL TOWN DWELLINGS, AND A FEW CHURCHES

BY

LEWIS A. COFFIN, JR., HENRY M. POLHEMUS AND ADDISON F. WORTHINGTON

NEW YORK

CHARLES SCRIBNER'S SONS

I92I 
Cooper Hewitt munseum

4. C C Corxacert 192, , ax Copyright, 1921, By
CHARLES SCRIBNER'S SONS

NA
OHI
CGL
CHM.

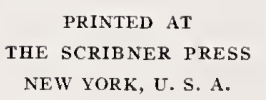




\section{O N T E N T S}

Small French Buildings . . . . . . . . . . . . . . . I

Cottages . . . . . . . . . . . . . . . . . . . . . . . . . . 5

Churches and Chapels . . . . . . . . . . . . . . . . . 6 .

Town Houses . . . . . . . . . . . . . . . . . . . 73

Châteaux, Manors, and Farm Groups . . . . . . . . . . II5

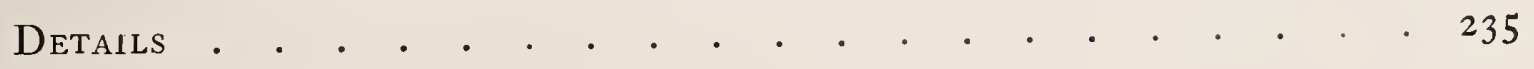





\section{L L U S T R A T I O N S}

\section{COTTAGES}

Plate I. Hamlet near L'Amaury, Seine-et-Oise . . . . . . . . . . . Frontispiece

Plate 2. Shop at Concarneau, Finistère . . . . . . . . . . . . . . . . 7

Plate 3. Brittany cottage . . . . . . . . . . . . . . . . . . . . . 9

Plate 4. Typical old Brittany cottage . . . . . . . . . . . . . . . . II

Plate 5. Cottage near Freulleville, Seine-Inférieure _ . . . . . . . . . . I 3

Plate 6. Farmer's cottage near Dieppe, Seine-Inférieure . . . . . . . . . . I5

Plate 7. Stone cottages at Conches, Eure . . . . . . . . . . . . . . . . . I7

PLAte 8. Roadside cottage near Beuzeville, Eure . . . . . . . . . . . . 19

Plate 9. Cottage at Luneray, Seine-Inférieure . . . . . . . . . . . . . 19

Plate 10. Thatched roof Normandy cottage in typical setting . . . . . . . . . 2 I

Plate il. Cottage near Tôtes, Seine-Inférieure . . . . . . . . . . . . . 23

Plate 1 2. Cottage near 'Tôtes, Seine-Inférieure . . . . . . . . . . . . . 23

Plate 13. Farm cottage near Beaufay, Sarthe . . . . . . . . . . . . . 25

Plate I4. Cottage near Tôtes, Seine-Inférieure . . . . . . . . . . . . . 25

Plate 15. Farm cottage near Beaufay, Sarthe . . . . . . . . . . . . . 27

Plate 16. Roadside cottage near Lisieux, Calvados . . . . . . . . . . . . 29

Plate 17. Thirteenth-century house at La Saussaye . . . . . . . . . . . . 3I

Plate i 8. Hamlet near L’Amaury, Seine-et-Oise . . . . . . . . . . . . . 33

Plate 19. Cottage near Amfreville, Eure . . . . . . . . . . . . . . 33

Plate 20. Farm at Bieville-en-Ange, Calvados . . . . . . . . . . . . . 35

Plate 21. Roadside cottage near Authon, Eure-et-Loir . . . . . . . . . . 35

Plate 22. Hamlet near Yerville, Seine-Inférieure . . . . . . . . . . . . 37

Plate 23. Cottage near Quiévercourt, Seine-Inférieure . . . . . . . . . . . 37 


\section{ILLUSTRATIONS}

Plate 24. Cottage near Mélamare, Seine-Inférieure .

Plate 25. Village near Authon, Eure-et-Loir . . . . . . . . . . . . . 4 I

Plate 26. Cottage on the Dordogne, near St. Cyprien . . . . . . . . . . . 43

Plate 27. An entrance to Montfort, Seine-et-Oise . . . . . . . . . . . . 45

Plate 28. Village street, Montfort, Seine-et-Oise . . . . . . . . . . . . . 45

Plate 29. Cottage near Damville, Eure . . . . . . . . . . . . . . . 47

Plate 30. Cottage of Savigny, Manche . . . . . . . . . . . . . . . 49

Plate 3r. Cottage near St. Jacques, Plomb du Cantal . . . . . . . . . . . 5 r

Plate 32. Farmhouse at Marolles, Calvados . . . . . . . . . . . . . . 53

Plate 33. House in the Dordogne Valley . . . . . . . . . . . . . . 53

Plate 34. A southern village . . . . . . . . . . . . . . . . . 55

Plate 35. Cottage near Ste. Foy-la-Grande, Gironde . . . . . . . . . . . 57

Plate 36. Cottage near Bergerac, Dordogne . . . . . . . . . . . . . . 57

\section{CHAPELS}

Plate 37. Chapel at Romorantin, Loir-et-Cher . . . . . . . . . . . . . 6I

Plate 38. Farm chapel near Brécy, Calvados . . . . . . . . . . . . . 6I

Plate 39. Château chapel at Millançay, Loir-et-Cher . . . . . . . . . . . 63

Plate 40. St. Léger-en-Yvelines, Seine-et-Oise . . . . . . . . . . . . . 63

Plate 4I. Hamlet near Concarneau, Finistère . . . . . . . . . . . . . 65

Plate 42. Church at Vaucelle, Calvados . . . . . . . . . . . . . . . . . 67

Plate 43. Church at Daoulas, Finistère . . . . . . . . . . . . . . . . . . 67

Plate 44. Pont Audemer, Eure . . . . . . . . . . . . . . . . . . . . . . 69

Plate 45. Chapel at Château Gratot, near Coutances, Manche . . . . . . . . 69

Plate 46. Church at Noisy-sur-Oise . . . . . . . . . . . . . . . . $7 \mathrm{r}$

\section{TOWN HOUSES}

Plate 47. Shop at Landerneau, Finistère . . . . . . . . . . . . 75

Plate 48. House at Landerneau, Finistère . . . . . . . . . . . . . . 77

Plate 49. House at Landerneau, Finistère . . . . . . . . . . . . . . 79 


\section{ILLUSTRATIONS}

Plate 50. Hôtel des Trois Piliers, Landerneau, Finistère . . . . . . . . . . . 79

Plate 5 r. House at Hennebont, Morbihan . . . . . . . . . . . . . . 8I

Plate 52. Auray, Morbihan. . . . . . . . . . . . . . . . . . . 83

Plate 53. Le Mans, Sarthe . . . . . . . . . . . . . . . . . . 85

Plate 54. On the ramparts, Mont St. Michel, Manche _. . . . . . . . . . 87

Plate 55. Nogent-le-Rotrou, Eure-et-Loir . . . . . . . . . . . . . . 87

Plate 56. Houses at Conches, Eure-et-Loir . . . . . . . . . . . . . . 89

Plate 57. House at Compiègne, Oise . . . . . . . . . . . . . . . . 9 I

Plate 58. Old house at Mennetou-sur-Cher, Loir-et-Cher . . . . . . . . . . 93

Plate 59. House at Verneuil, Eure . . . . . . . . . . . . . . . . . 95

Plate 60. An old town house . . . . . . . . . . . . . . . . . . . . . 97

Plate 6r. Restaurant at Étampes, Seine-et-Oise . . . . . . . . . . . . . 99

Plate 62. House at Beaulieu, Corrèze . . . . . . . . . . . . . . . . IoI

Plate 63. House at Couches-les-Mines, Saône-et-Loire . . . . . . . . . . . 103

Plate 64. House at Arnay-le-Duc, Côte-d'Or . . . . . . . . . . . . . . 105

Plate 65. Pont Audemer, Eure . . . . . . . . . . . . . . . . . . 105

Plate 66. Caudebec-en-Caux, Seine-Inférieure . . . . . . . . . . . . . . 107

Plate 67. House between church buttresses, La Charité, Nièvre . . . . . . . . 107

Plate 68. Street at Conches, Eure . . . . . . . . . . . . . . . . . . . IO9

Plate 69. House at Arnay-le-Duc, Côte-d'Or . . . . . . . . . . . . . . . 109

Plate 7o. House at Arnay-le-Duc, Côte-d'Or . . . . . . . . . . . . . . Ii I

Plate 7i. House at Arnay-le-Duc, Côte-d'Or . . . . . . . . . . . . . . II3

\section{CHÂTEAUY, MANORS, AND FARM GROUPS}

Plate 72. Entrance to manor farmyard near Demigny, Saone-et-Loire . . . . . . I I9

Plate 73. Pigeon-house, manor near Demigny, Saône-et-Loire . . . . . . . . . I2I

Plate 74. Garden-house near Hennebont, Morbihan . . . . . . . . . . . I23

Plate 75. Château Gratot, near Coutances, Manche . . . . . . . . . . . I 25

Plate 76. Garden-house near Hennebont, Morbihan . . . . . . . . . . I25

Plate 77. Le manoir de Rouazle, Finistère . . . . . . . . . . . . . . I27 


\section{ILLUSTRATIONS}

Plate 78. Farm on Blaret River above Hennebont, Morbihan .

Plate 79. House at Guiscard

Plate 80. House near Mercœur, Corrèze

Plate 8I. Farmhouse near St. Cyprien, Dordogne Valley

Plate 82. House at Brion, Saône-et-Loire.

Plate 83. Farmhouse at St. Pierre-le-Viger, Seine-Inférieure

Plate 84. Manor at Sainte-Marie-aux-Anglais, Calvados

Plate 85. House at Esclarelles, Seine-Inférieure .

Plate 86. Manor near Freulleville, Seine-Inférieure .

Plate 87. Farmyard near Freulleville, Seine-Inférieure

Plate 88. Entrance to farm near Neufchâtel .

Plate 89. Manor farmyard near Freulleville, Seine-Inférieure

Plate 90. Farmhouse near Lisieux, Calvados . . . . . . . . . . . . . . . . I45

Plate 9i. Farmyard side of manor near Bures, Seine-Inférieure . . . . . . . . I47

Plate 92. Manor gate near Bures, Seine-Inférieure . . . . . . . . . . . . 147

Plate 93. Farmyard, manor near Bures, Seine-Inférieure . . . . . . . . . . I49

Plate 94. Farm buildings, manor near Bures, Seine-Inférieure . . . . . . . . . I49

Plate 95. Farm group near Neufchâtel, Seine-Inférieure . . . . . . . . . . I5I

Plate 96. Horse farm near Nogent-le-Rotrou, Eure-et-Loir . . . . . . . . . I 5 I

Plate 97. Manor stables at Arques-la-Bataille, Seine-Inférieure . . . . . . . . I53

Plate 98. Manor at Esclarelles, Seine-Inférieure . . . . . . . . . . . . . I 53

Plate 99. Manor at Croixdalle, Seine-Inférieure . . . . . . . . . . . . . I55

Plate ioo. Inn near Bourdamville, Seine-Inférieure . . . . . . . . . . . . I55

Plate ioi. Château de Bémécourt, Eure . . . . . . . . . . . . . . . . . . I57

Plate 102. Sixteenth-century manor, Monteille, Calvados . . . . . . . . . . I57

Plate I03. Gateway, Manoir d’Ango, Varengeville, Seine-Inférieure . . . . . . . I59

Plate 104. Entrance to courtyard, Manoir d’Ango, Varengeville, Seine-Inférieure . . . $\quad$ I59

Plate I05. Farmhouse near Yerville, Seine-Inférieure . . . . . . . . . . . I6I

Plate io6. Manor near Lintot, Seine-Inférieure . . . . . . . . . . . . . I6 I

Plate 107. Manor at Omverville, Seine-et-Oise . . . . . . . . . . . . . 163 


\section{ILLUSTRATIONS}

Plate 108. Stables near Brécy, Calvados.

Plate iog. Farmyard near Brécy, Calvados

Plate i io. Farmyard, St. Jean-de-Follerville, Seine-Inférieure . . . . . . . . . I67

Plate I I I. Farm building near St. Léger, Saône-et-Loire . . . . . . . . . . 167

Plate i i2. Farmyard near Brézolles, Eure-et-Loir . . . . . . . . . . . . 169

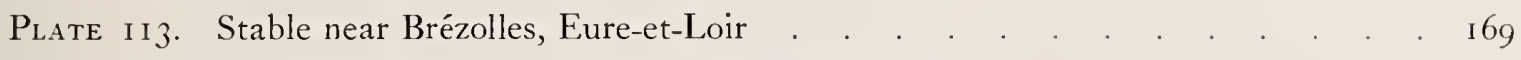

Plate I I4. Farmhouse at St. Pierre-le-Viger, Seine-Inférieure . . . . . . . . . I7I

Plate I I5. Farm building near Brézolles, Eure-et-Loir _ . . . . . . . . . I7I

Plate rr6. Entrance court façade, Château de Brécy, near Bayeux, Calvados . . . . I73

Plate i I7. Entrance, Château de Brécy, near Bayeux, Calvados . . . . . . . . I75

Plate i i 8. General plan of Château de Brécy, near Bayeux, Calvados . . . . . . 177

Plate i ig. Château de Brécy, near Bayeux, Calvados . . . . . . . . . . . I79

Plate I 20. Farm near St. Léger, Saône-et-Loire . . . . . . . . . . . . . I79

Plate i2 I. Château le Pin, Calvados . . . . . . . . . . . . . . . . . . . I8 I

Plate I22. Stables of the Château Cheverny . . . . . . . . . . . . . . I $8_{3}$

Plate I23. Stable building, Château du Bouissard, near Brézolles . . . . . . . . I 85

Plate 1 24. Château de Saint-Germain-de-Livet, Calvados . . . . . . . . . . I87

Plate 125. Château de Cantepie-Lisieux . . . . . . . . . . . . . . . . I89

Plate I26. Entrance to Château at Couchey, Côte-d'Or . . . . . . . . . . IgI

Plate 127. Stable-yard, Millançay, Loir-et-Cher . . . . . . . . . . . . . IgI

Plate 128. Farmhouse at Monthelon, Saône-et-Loire . . . . . . . . . . . 193

Plate I29. Farmhouse near Le Neubourg, Eure . . . . . . . . . . . . . 195

Plate izo. Farmhouse at Monthelon, Saône-et-Loire . . . . . . . . . . . 195

Plate I3I. Château near Millançay, Loir-et-Cher . . . . . . . . . . . . . 197

Plate 132. Horse-farm courtyard near Nogent-le-Rotrou, Eure-et-Loir . . . . . . 197

Plate 133. Château de Villepreaux, Creuse . . . . . . . . . . . . . . . . . . . 199

Plate i34. Farm near St. Léger, Saône-et-Loire . . . . . . . . . . . . . 20 I

Plate 135. Farm near St. Léger, Saône-et-Loire . . . . . . . . . . . . . 203

Plate I36. House near Vic-sur-Cère, Cantal . . . . . . . . . . . . . . 205

Plate 137. Farm near Gourdon, Lot . . . . . . . . . . . . . . . . 207 


\section{ILLUSTRATIONS}

Plate i38. Manoir Duval near Freulleville, Seine-Inférieure . . . . . . . . . 207

Plate i39. Farm near Gourdon . . . . . . . . . . . . . . . . . 209

Plate I 4O. Farm group near Rambouillet, Seine-et-Oise . . . . . . . . . . 2I I

Plate I 4I. Stable-yard near Demigny, Saône-et-Loire . . . . . . . . . . . 2i I

Plate I42. Farm near La Remuée, Seine-Inférieure . . . . . . . . . . . . 213

Plate i43. Mill near Murat, Cantal . . . . . . . . . . . . . . . . 2I3

Plate i 44. Farm near Domme, Dordogne . . . . . . . . . . . . . 215

Plate 145. Farm group near Gourdon, Lot . . . . . . . . . . . . . 215

Plate 146. Farmhouse near St. Cyprien, Dordogne Valley . . . . . . . . . . 217

Plate 147. Manor at Vaucelles, Calvados . . . . . . . . . . . . . . 219

Plate I48. Gatehouse of Château de Royalhen, South Compiègne . . . . . . . 221

Plate I 49. House at St. Symphories, Tours . . . . . . . . . . . . . . 223

Plate I 50. House at St. Symphories, Tours . . . . . . . . . . . . . . 223

Plate i5i. Plan of manor near Libourne, Gironde . . . . . . . . . . . 225

Plate I 52. Garden elevation of manor near Libourne, Gironde . . . . . . . . 227

Plate 153. Section and details of manor near Libourne, Gironde . . . . . . . 229

Plate I 54. Farm entrance, manor near Demigny, Saône-et-Loire . . . . . . . . 23I

Plate I55. Stable near St. Emilion, Gironde . . . . . . . . . . . . . . 23 I

Plate i 56 . Manor at Arques-la-Bataille . . . . . . . . . . . . . . . 233

\section{DETAILS}

Plate i 57. Farm-gate near La Remuée, Seine-Inférieure . . . . . . . . . . 237

Plate 158. Pigeon-house at La Grande Verrière, Saône-et-Loire . . . . . . . . 239

Plate I 59. Pigeon-house, Manoir Duval, near Freulleville, Seine-Inférieure . . . . . 239

Plate i6o. Pigeon-house near Brézolles, Eure-et-Loir . . . . . . . . . . . 24 I

Plate i6i. Pigeon-house near Chartres . . . . . . . . . . . . . . . 243

Plate 162. An octagonal pigeon-house . . . . . . . . . . . . . . . . 245

Plate i63. Balustrade at Billom, Puy-de-Dôme . . . . . . . . . . . . . 247

Plate 164. Window grille, Manoir d'Ango, Varengeville, Seine-Inférieure . . . . 247

Plate 165. Loggia, Manoir d'Ango, Varengeville, Seine-Inférieure . . . . . . . 249 


\section{ILLUSTRATIONS}

Plate I66. Detail, house at Verneuil, Eure . . . . . . . . . . . . . . 249

Plate i67. Bridge at Vendôme, Loir-et-Cher . . . . . . . . . . . . . . 25 I

Plate i68. Garden-gate, Château de Sorel, Dreux, Eure . . . . . . . . . . 253

Plate i69. Farm-gate near St. Jean-de-Follerville, Seine-Inférieure . . . . . . . 255

Plate 170. Gate from garden to farm, Château de Brécy, near Bayeux . . . . . . 255

Plate i7i. Farmhouse doors, Monthelon, Saône-et-Loire . . . . . . . . . 257

Plate 172. Gate near Evreux, Eure . . . . . . . . . . . . . . . . 259

Plate I73. Farm-gate near St. Jean-de-Follerville, Seine-Inférieure . . . . . . . 259

Plate I74. Farm-gate near La Remuée, Seine-Inférieure . . . . . . . . . . 26 I

Plate 175. Doorway at Le Mans, Sarthe . . . . . . . . . . . . . . . 263

Plate i76. Doorway at Arnay-le-Duc, Côte-d'Or . . . . . . . . . . . . . . 263

Plate 177. Door at Billom, Puy-de-Dôme . . . . . . . . . . . . . . 265

Plate 178. Church entrance at Honfleur, Seine-Inférieure . . . . . . . . . . 267

Plate 179. Farm entrance near Lintot, Seine-Inférieure . . . . . . . . . . 267

Plate I80. Detail of stone garden-gate of house at Brion, Saône-et-Loire . . . . . 269

Plate i 8I. Garden-gate, Arnay-le-Duc, Côte-d'Or . . . . . . . . . . . . 27 I

Plate 182. Garden-gate, Montfort, Seine-et-Oise . . . . . . . . . . . 273

Plate I83. Entrance to Château de St. Georges, Montagne, Gironde . . . . . . . 275 



\section{S M A L L F R E N C H B U I L D I N G S}

THE minor architecture of France, of which this book can unfortunately cover but a small part, comprises a field worthy, we believe, of further study and attention. It is astonishing that these small buildings have received so little attention as compared with similar types of other countries, notably of I taly and of England, in regard to which a considerable number of books are available. Why these buildings of France have not been more sought out and preserved in publication, it is difficult to say. Perhaps it is because France seems so distinctly a country of monumental architecture, that its lesser and more modest buildings of the country and the provinces have come little to the attention of the student; perhaps because the finer examples are quite widely scattered, so that any collection of such material must of necessity be difficult. In gathering the pictures and other data, we covered, on foot and cycle, the sections of France that seemed most full of promise: Normandy, Brittany, the Côte-d'Or, the Dordogne section, and the fertile valleys of the interior. Of course it was impossible to reap the full harvest even of the parts visited, and we know that a vast mass of excellent material remains untouched as yet. It is hoped that some time soon most of it may be gathered together in published form, for much that is worth while disappears year by year.

In choosing our material, we have purposely avoided the châteaux, particularly those familiar ones of the Loire valley, as well as the larger and better-known buildings in general. Our idea has been to include only the smaller châteaux, quite unfamiliar ones off the beaten track, the manors, the farm groups, and the cottages of the peasants. At first there was every intention to omit all churches, but in Normandy and often elsewhere it was quite impossible to resist photographing the quaint little churches and chapels that fit in so well with the country, the people, and the surrounding hamlets. And now it is as impossible to refrain from including a few of these. The majority of the photographs we took ourselves, so for their quality we can hold to account only ourselves and the fickle weather of France. A few pictures we bought and a few very interesting ones have been contributed by Mr. Philip L. Goodwin, to whom our thanks are given.

There is no truer mirror of a people and a civilization than their informal architecture. In it there has been no attempt at artificial effect and very small obeisance to the passing fashions. The buildings of the French farmer, the small landowner, and the peasant, are as indigenous to their soil as the poplar-trees and poppies in the fields. The Frenchman is and always has been a lover of fine words, of gay colors, of flowered gardens, of piquancy, and of originality. So, too, are his 


\section{SMALL FRENCH BUILDINGS}

buildings: original, full of piquant interest, often gay of color, and invariably set around with hedge and flowers.

The variety of types- the châteaux, the manors, farms, and peasant cottages -reflect the state of society in the past, those widely divergent conditions of wealth which existed and still exist to a lesser extent. Then, too, we can discern the influences that the bordering states have had, where the sections were once under the control of some neighbor country, as, for instance, in Normandy, where the rural types of buildings are distinctly English in character and material; and on the southern slopes, where the influence of Italy can everywhere be seen. The path of the Renaissance remains clearly visible, where it swept up from Italy and Spain, fading out in the less accessible regions, until in the remote sections of Brittany the earlier or Gothic forms remain clearly predominant.

We are hopeful of the utility and of the pleasant savor of this material to any lover of good building-for its very freshness and playful originality, if for nothing else. There are a great many suggestions of value in these old types, most important perhaps in the roof shapes, the compositions of masses, and the fitness of house for setting. Color, unfortunately, cannot be reproduced, and many of the buildings are particularly of interest in their color and the tones of their materials. In the introductory notes before each group, an attempt has been made to convey as much as possible of the effect of the materials and of noteworthy details. Most particularly the thick stone walls, dry, buttered, or stuccoed, the broken masses of the roofs, the placing of chimneys and dormers, the fenestration, and the use of casements are features worthy of careful note. The usual French house has little to offer in the way of valuable suggestion for modern house arrangement, so we have thought best to omit any study of such plans from the material. However, two plans are included, both very interesting in their general scheme. That of the Château Brécy shows an excellent use of a sloping site for a walled garden in a series of ascending terraces; and that of a manor near Libourne, by the use of a grassed terrace, moat, and four immense linden-trees, has made very effective use of a practically flat site. Regarding detail, we have omitted any serious presentation, realizing that one of the most important suggestions we find in the minor French buildings, is that detail of elaborateness and quantity has not been needed.

Any one viewing a French village from a point of vantage, must remark on the manner in which it nestles into the surrounding country, forming a part and parcel of the land, and not staring out from the green earth like a blotch on the landscape. Age, of course, has had much to do with this quiet and agreeable result, but even more important are the materials that have been used in construction. In most cases they are strictly local: the stone from the near-by field or brook, thatch from the meadow, or slate from the hillside quarry close by. Therefore, it is quite natural that the buildings are but a more definitized, more human- 


\section{SMALL FRENCH BUILDINGS}

ized form of the country about, built in to rambling, picturesque shapes peculiarly suited to their sites, and in time covered with moss and vine. Then, too, the small towns and isolated buildings have not suffered from the disadvantages of eclecticism, except in a few unfortunate places; and all seem to go very pleasantly together, mildly ruled by tradition, no matter their age. Any student of town planning would do well to see in these French towns what variety may be attempted, what controlled spontaneity of design employed, and yet what a congruous whole, obtained.

The farm group is also particularly suggestive; to-day we have much of this sort of building. The typical French farm group, comprising numerous buildings, was almost invariably built around a court, very wide, walled about and planted with "espalier" fruit-trees. The informality of the grouping of the various buildings, the roof masses, walls, and entrance-gateways have many suggestions to offer. For country houses, the smaller, more informal châteaux, the manors as well as the larger farm buildings, are valuable for ideas of mass, materials, and details.

It is our hope that others may appreciate these little buildings and find in them some freshness and inspiration. And we can recommend, from pleasant and profitable experience, this simple sort of architecture to any one who may find himself in France, as being not so impressive as cathedrals or as magnificent as palaces, but very worth while. For in its quest, one learns to love the people, their songs and laughter, their wheat-fields and poppies, quite as fully as their buildings. We hope that this book may bring something new and refreshing and stimulate an enlivened interest in a field rather neglected and yet very worthy of study. 


\section{O T T A G E S}

UNDER this head have been grouped the small cottages of the peasant farmer, which have little architectural detail of any sort but the charm of utter simplicity, of wonderful color, and exact fitness for their settings. Along the white roads of France and through the fields, these little cottages snuggle down behind their hedges and flower-gardens, so old and softened in line and color that they seem a very part of the land itself. The roof lines are long and soft, and the buildings seldom more than one story and a half in height. The most usual arrangement consists of two main rooms:- a combination living-room and kitchen, and a bedroom--or maybe two-while the loft above is accessible only from an outside stairway and opening, and is chiefly for storage. Each room has an ample fireplace, and the kitchen contains the large bake-oven.

The materials of construction are in general strictly local, and the resulting uniformity is largely accountable for the artistic charm of the small French village. In the north are found the thatched roofs and half-timber construction along the farm roads, while nearer the towns there are more cottages of brick with pan-tile roofs. In Brittany there are many picturesque little cottages of stone, or stone podged over with stucco, with gabled, thatched, or slate roofs, and the small amount of detail more Gothic than aught else. The forms of the thatched cottages seem almost to have been inspired by the long, soft, hipped lines of the carefully stacked haymows; and the roofs themselves, often green with moss or with the ridges a growing mass of fleurs-de-lis, of course, blend beautifully with the landscape.

In central France are found many brick or white walled cottages with tile or thatch roofs, while in the southern parts most buildings have the flavor and suggestion of Italy or Spain, with large expanses of white stucco walls, symmetrically placed openings, and roll tile roofs with wide overhangs at the eaves, as illustrated in Plates 35 and 36.

Among the illustrations, Plate 3 shows a Brittany cottage of roughly faced local stone and thatched roof, as does Plate 30 . The thatch ridge has blossomed forth in flowers, and though the wall has been patched out, the effect is snug and pleasing in line. Plate 5 is an example of a brick cottage set down behind its garden and buried in vines. The hipped end of the roof is carried down nearly to the ground in a shed roof. Plates 8, 9, I4, and 17 are examples of half-timbered cottages, the half-timber frieze in the cottages near Beuzeville and Tôtes being often seen in such little buildings. The cottage at Quiévercourt on Plate 23 has an unusual treatment of the chimney, buttresses flanking its base, while Plate 29 shows a decorated brick-and-stone treatment of the chimney. The overhanging eaves at the end shelter the stairway to the loft. 



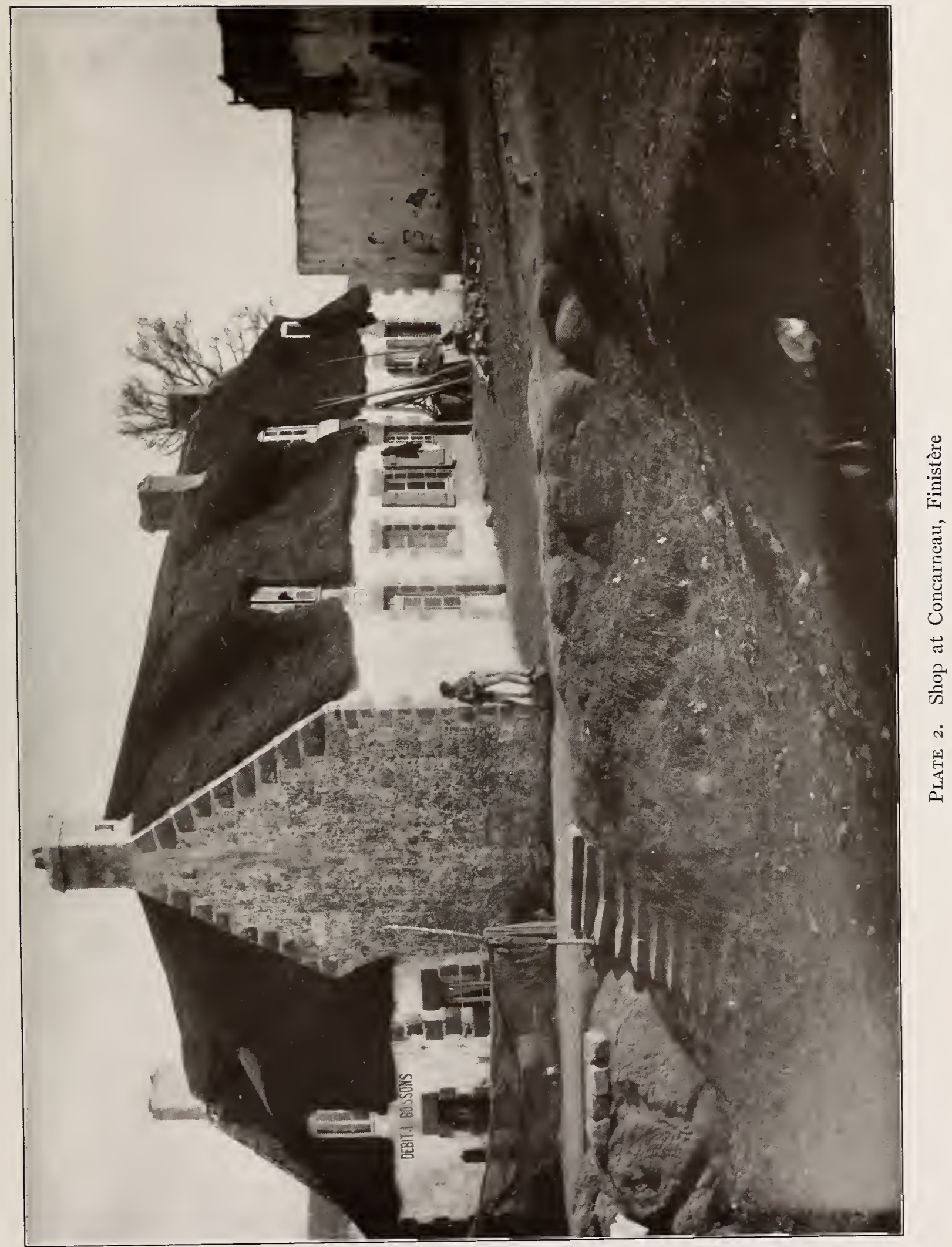





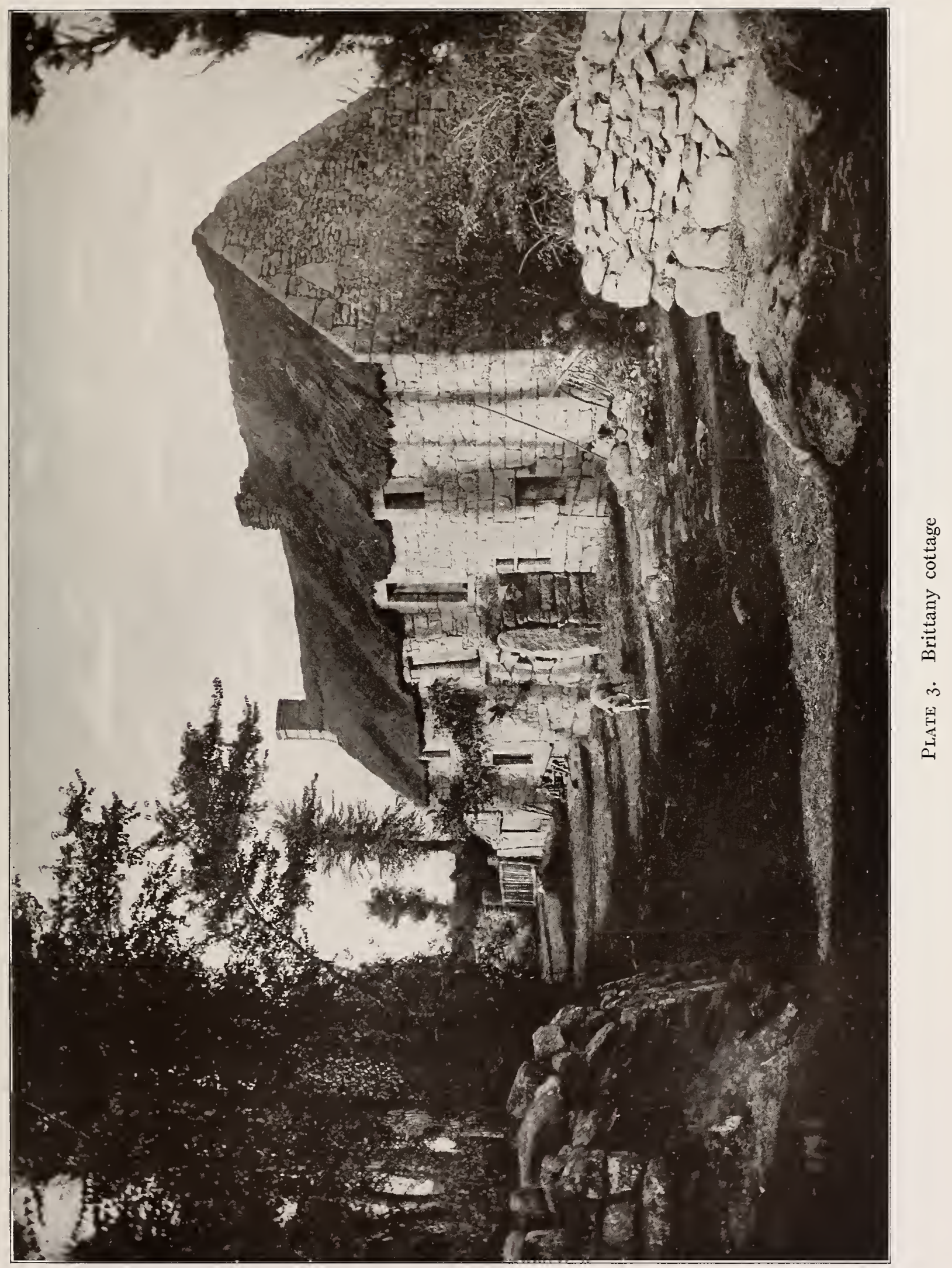





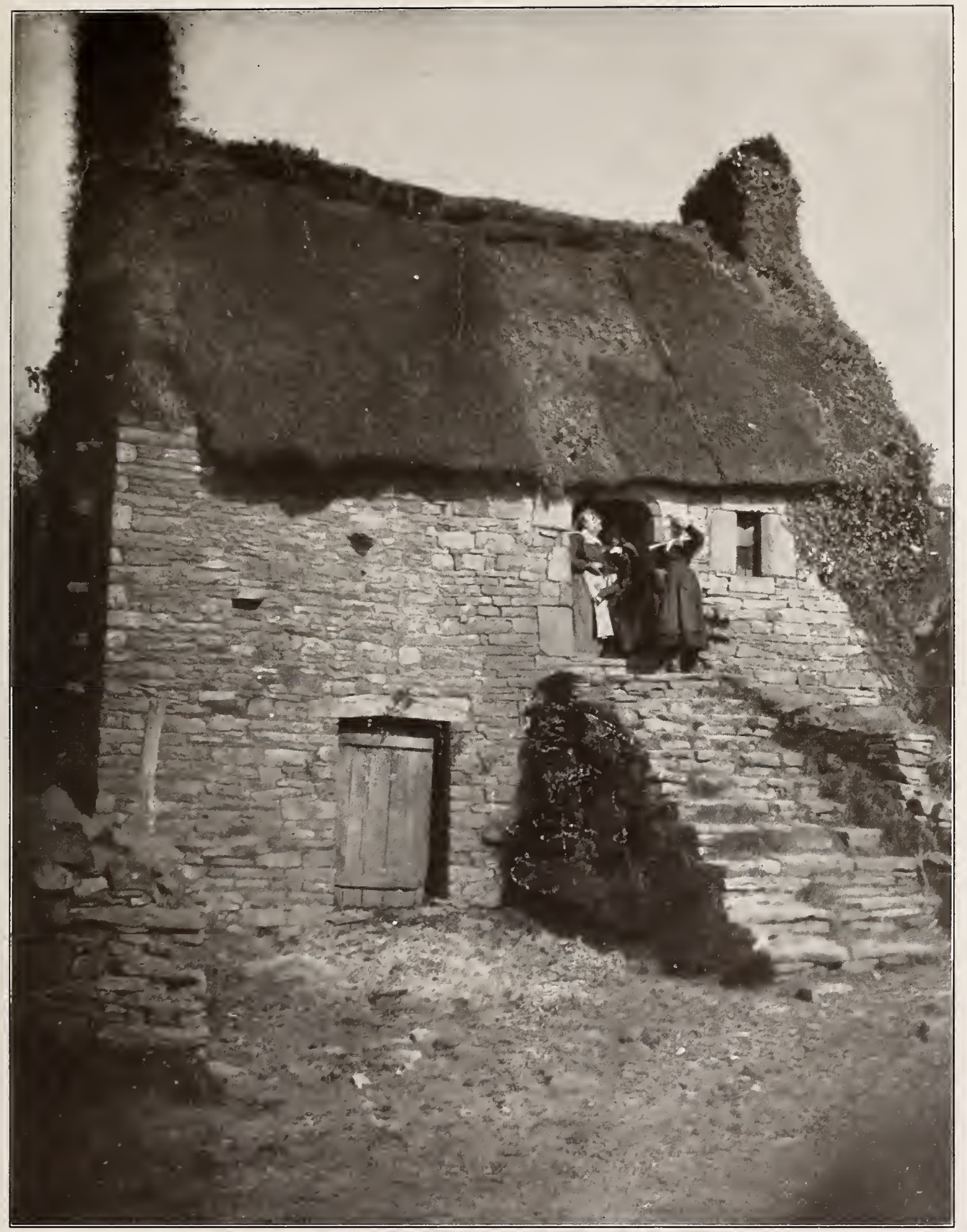

Plate 4. Typical old Brittany cottage 



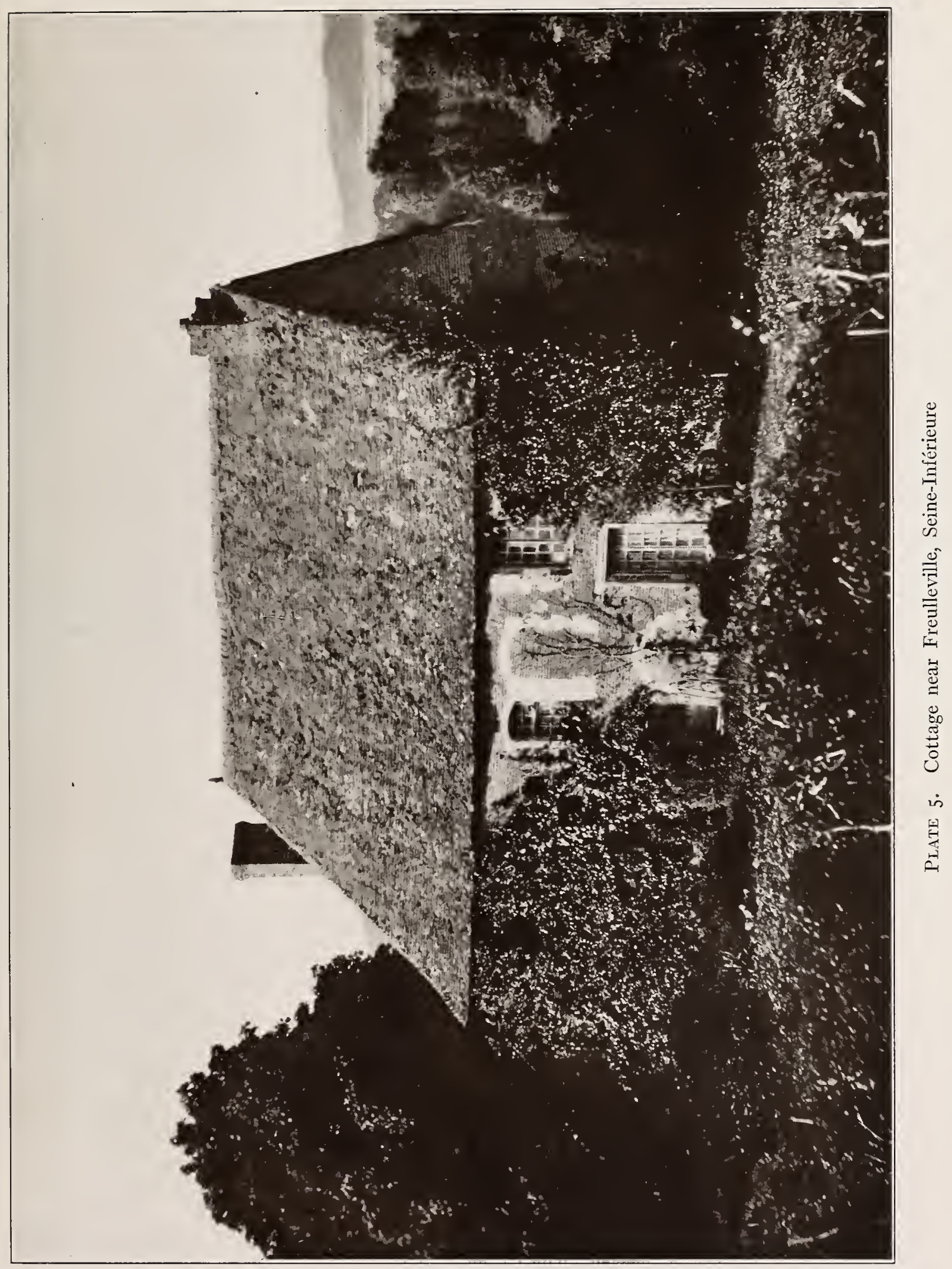





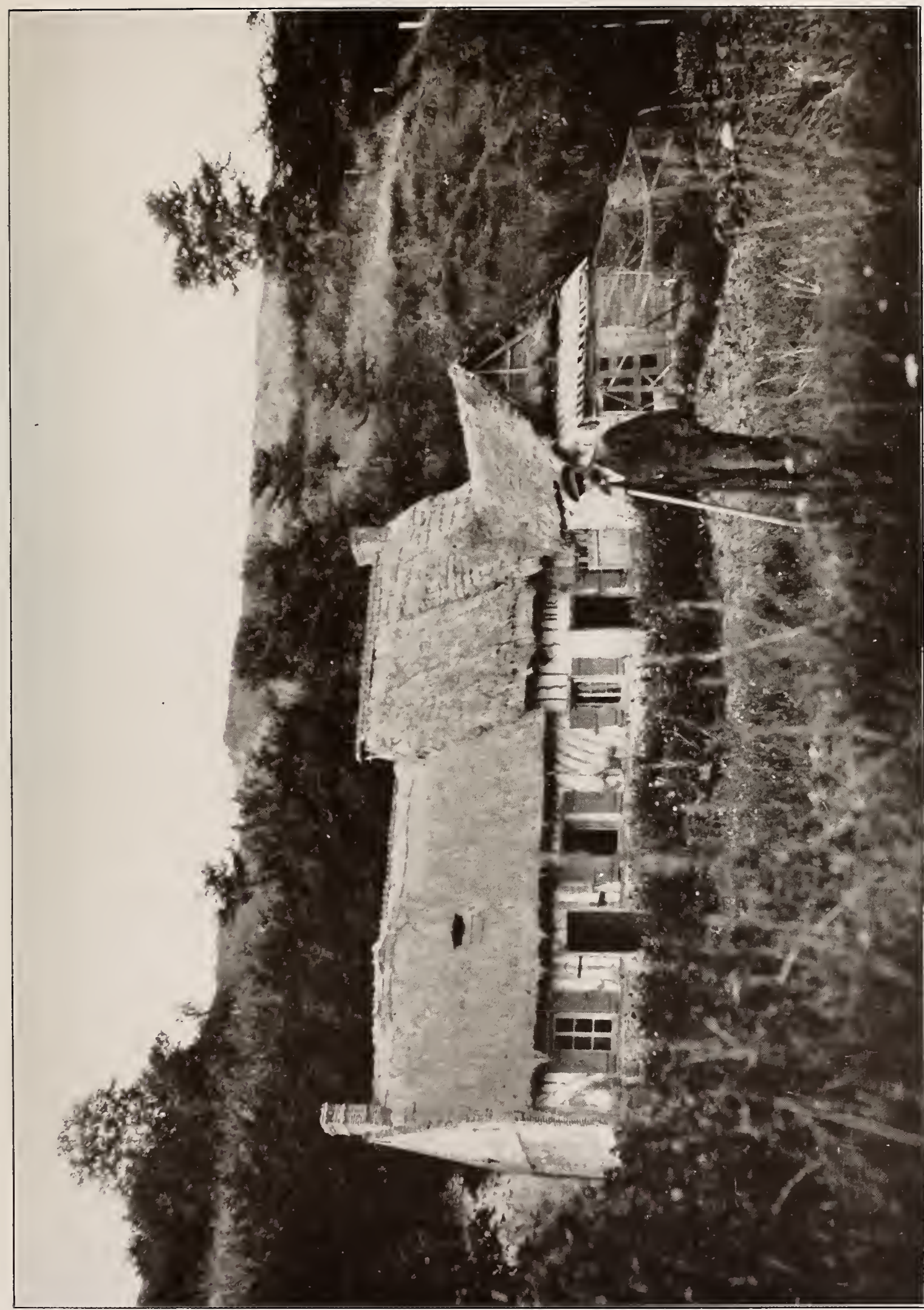

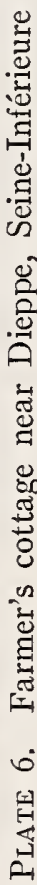





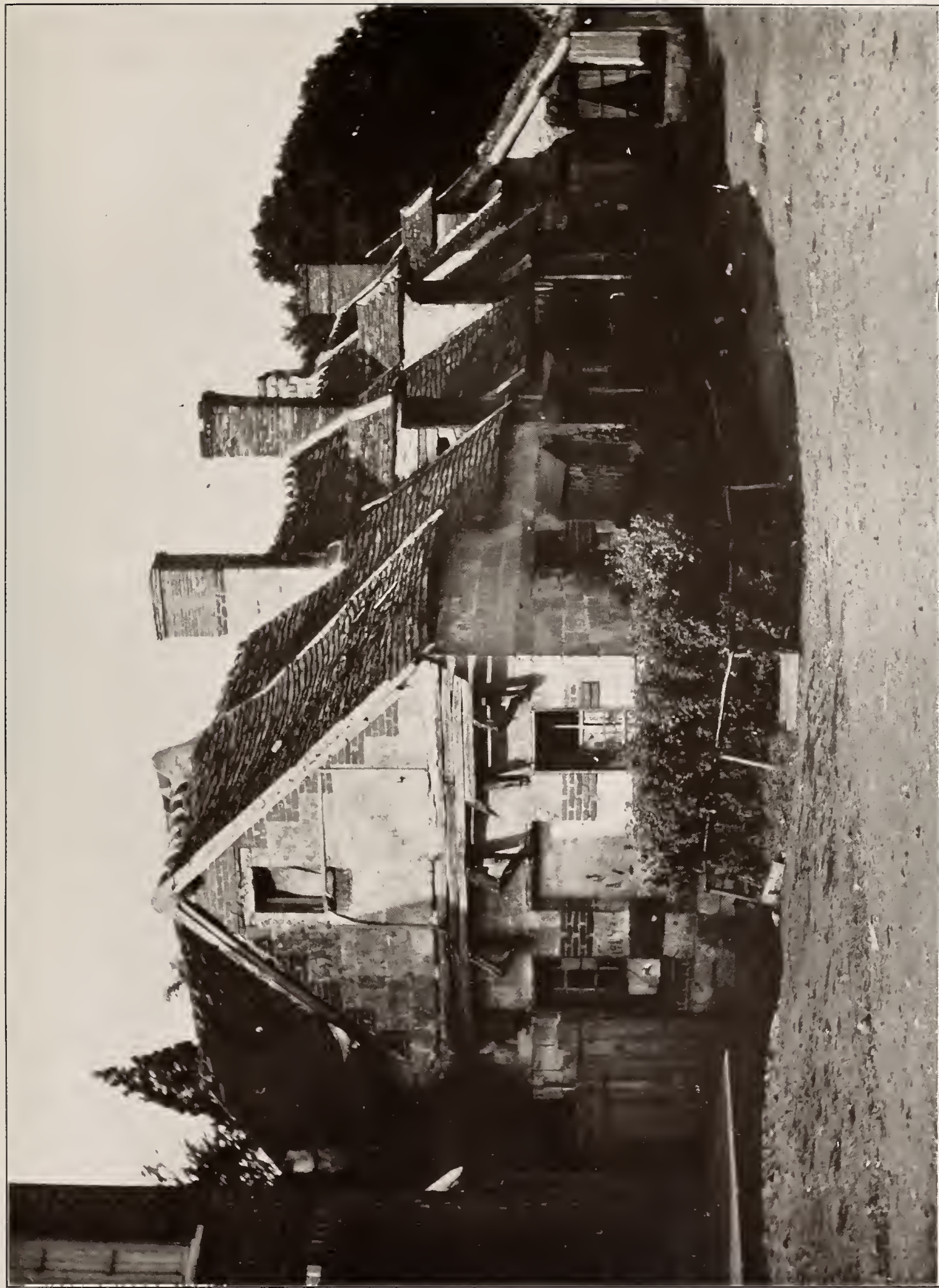

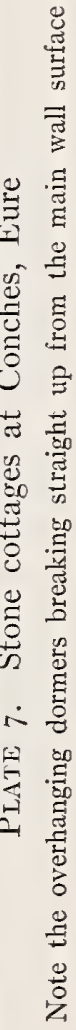





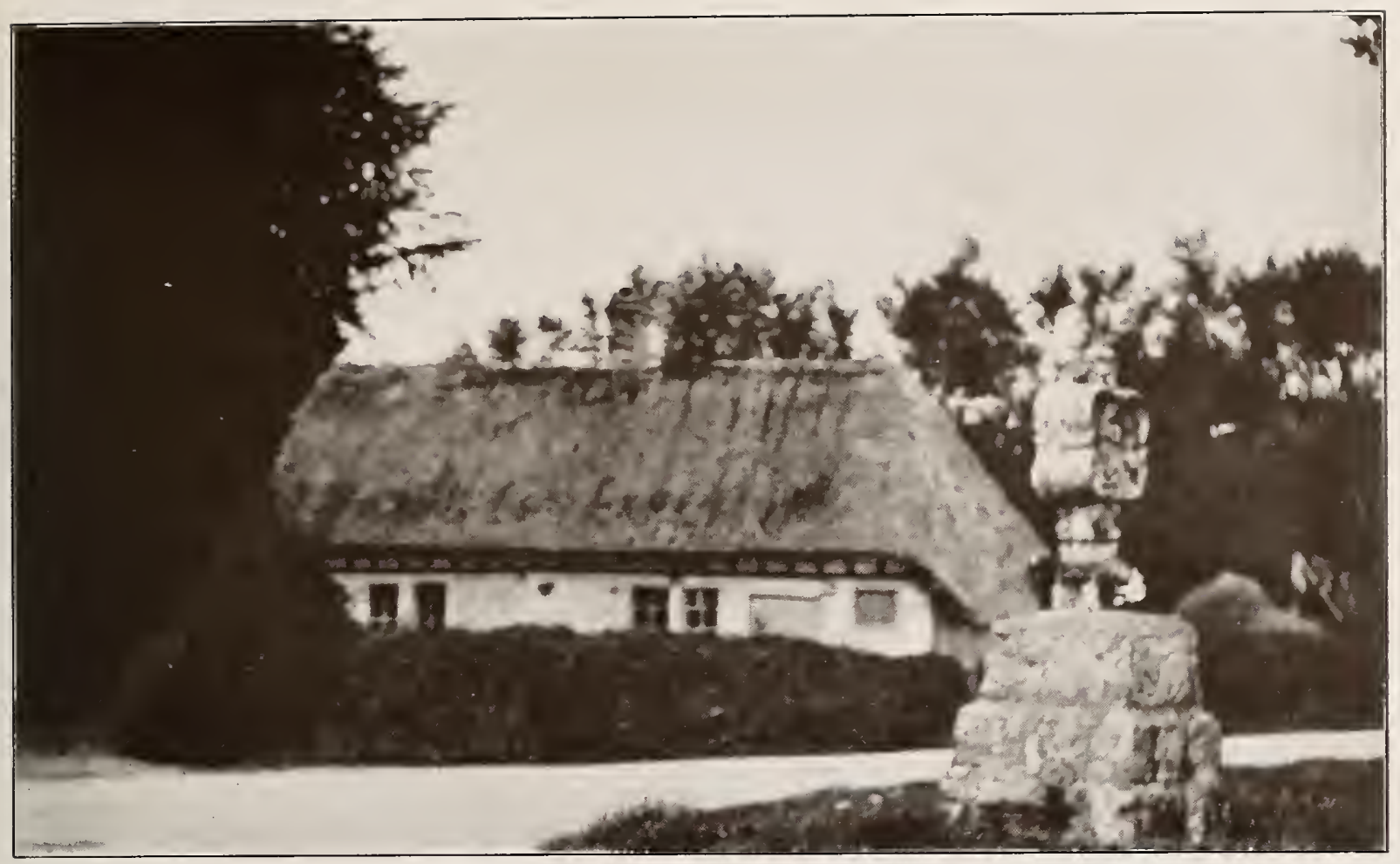

Plate 8. Roadside cottage near Beuzeville, Eure

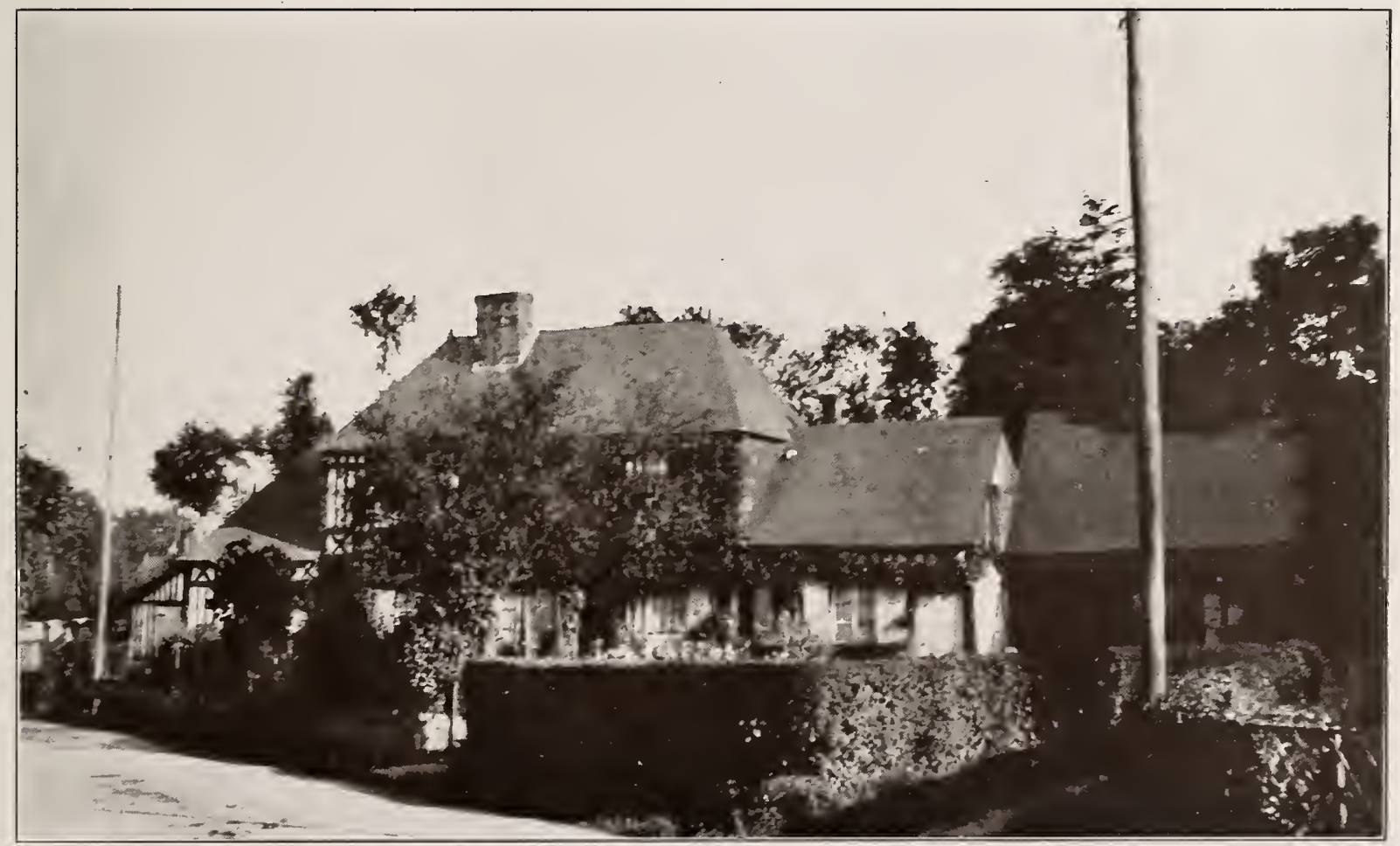

Plate 9. Cottage at Luneray, Seine-Inférieure 



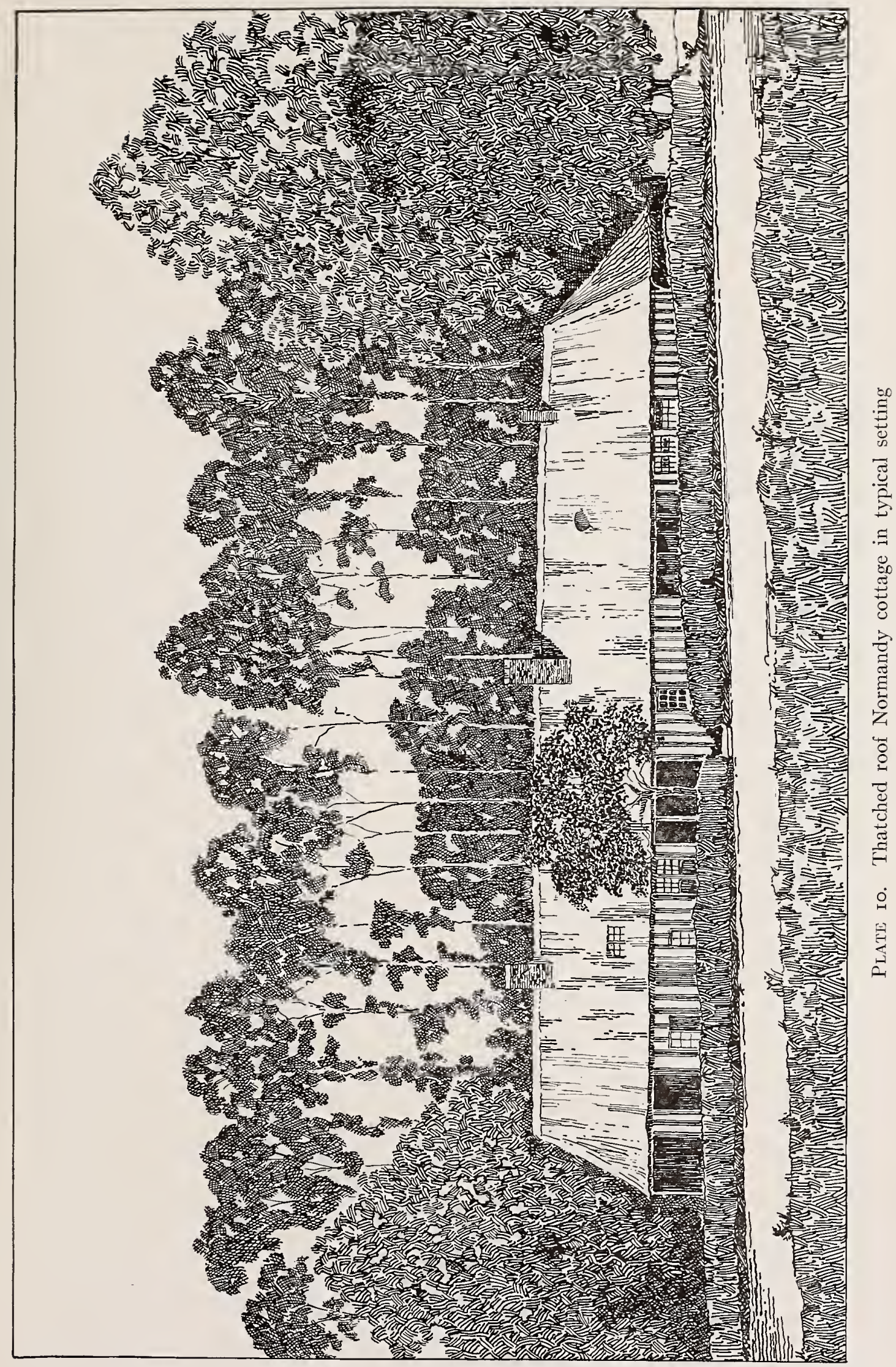





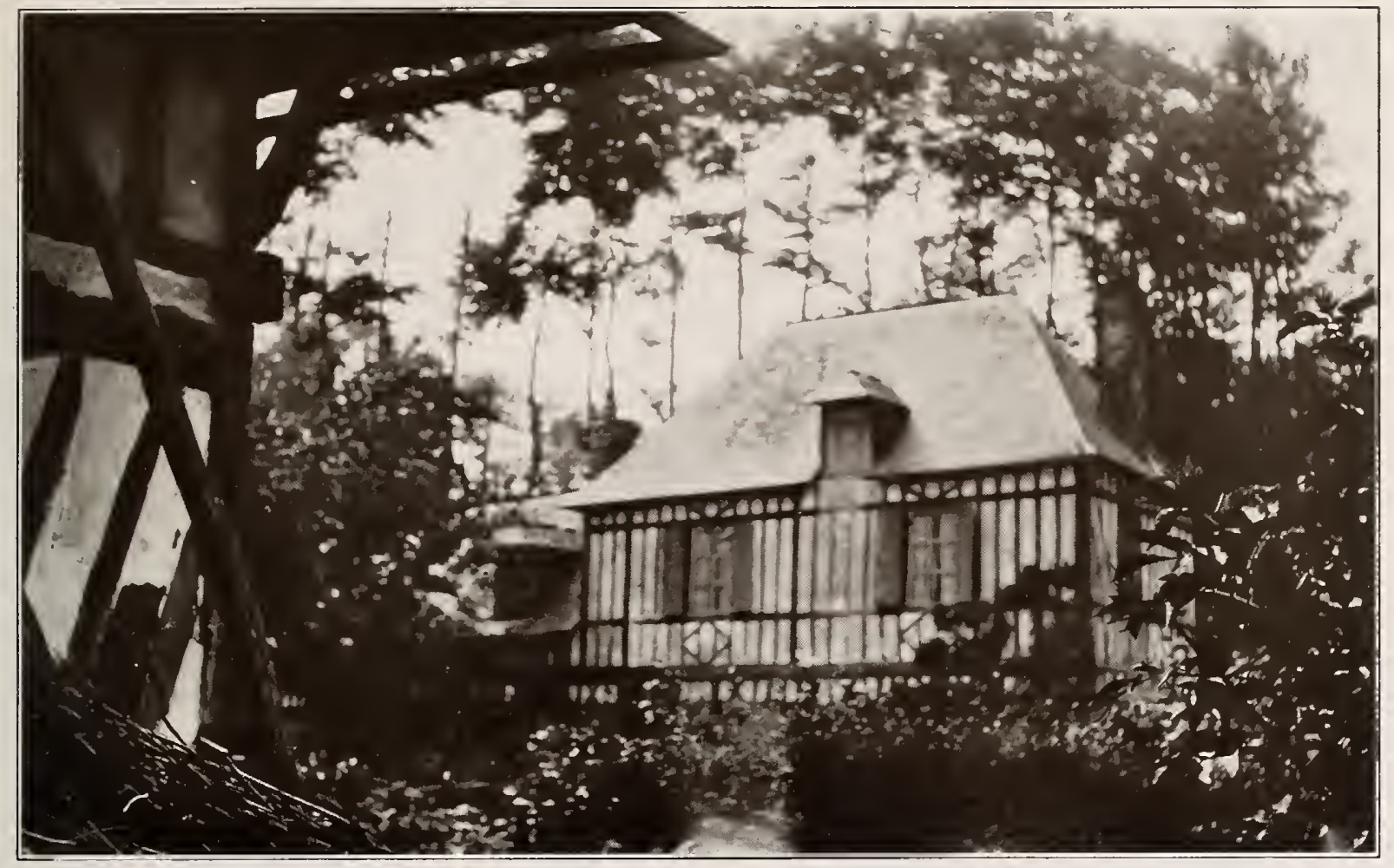

Plate ir. Cottage near Tôtes, Seine-Inférieure

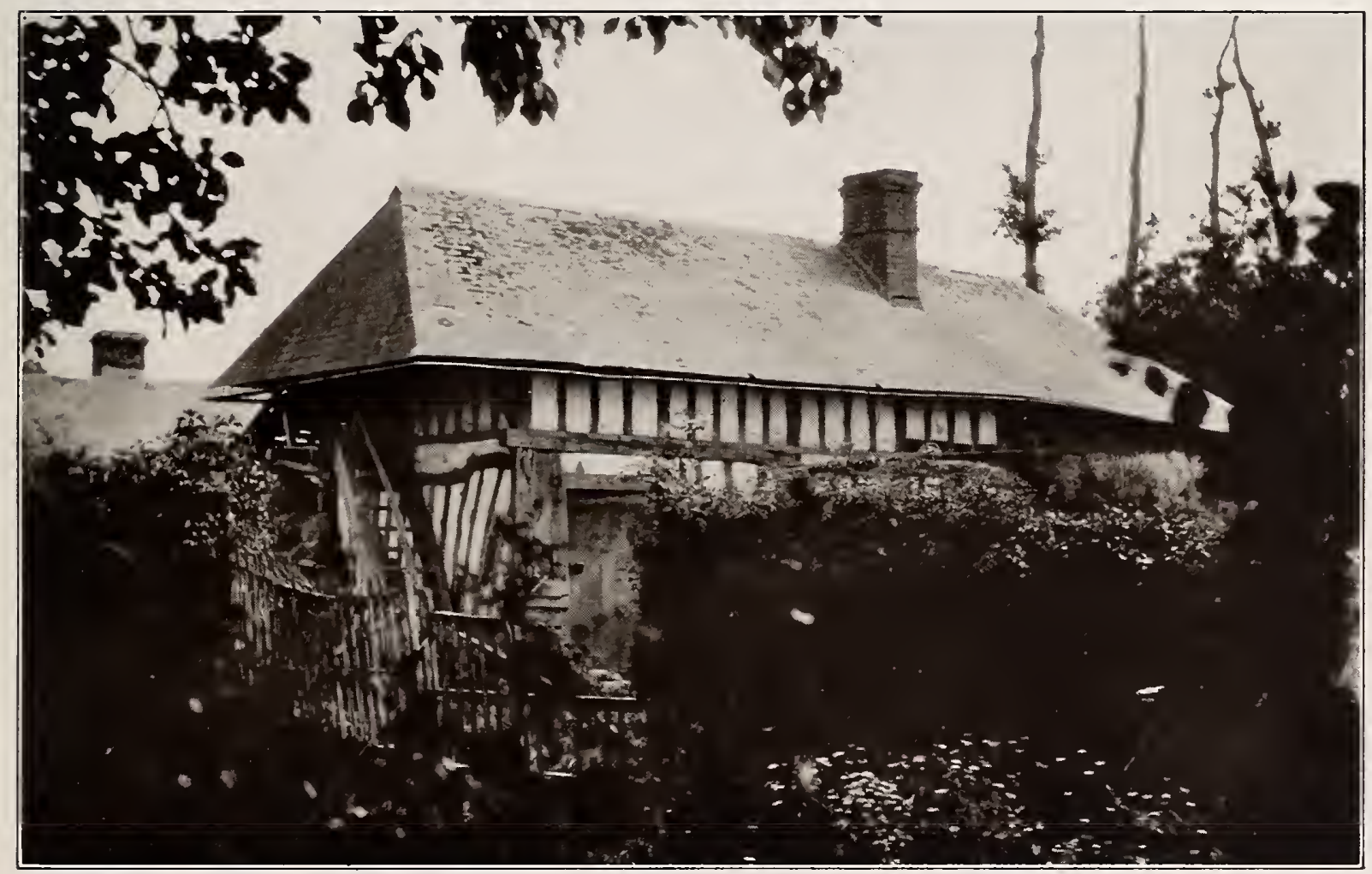

Plate i2. Cottage near Tôtes, Seine-Inférieure 



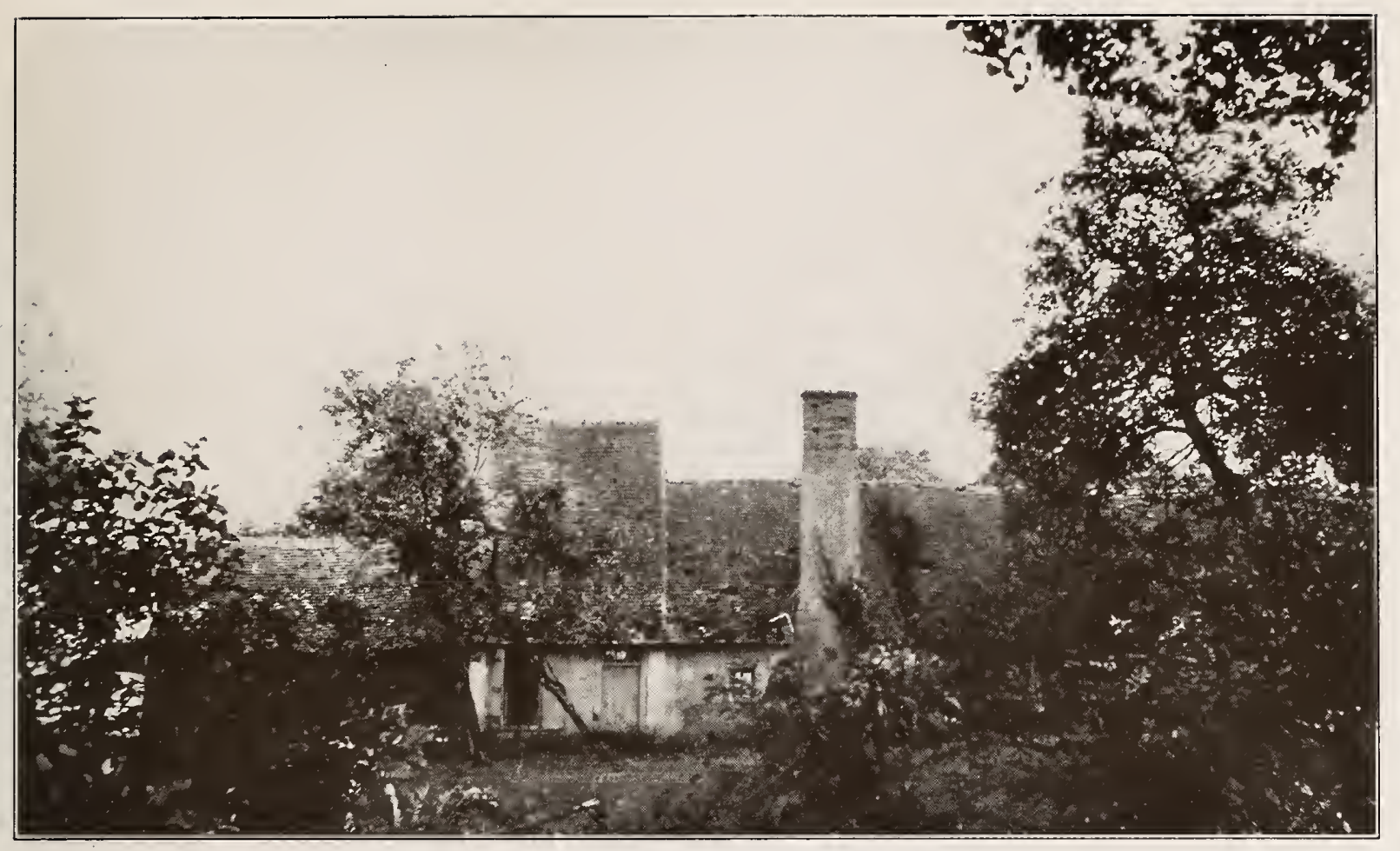

Plate 13. Farm cottage near Beaufay, Sarthe

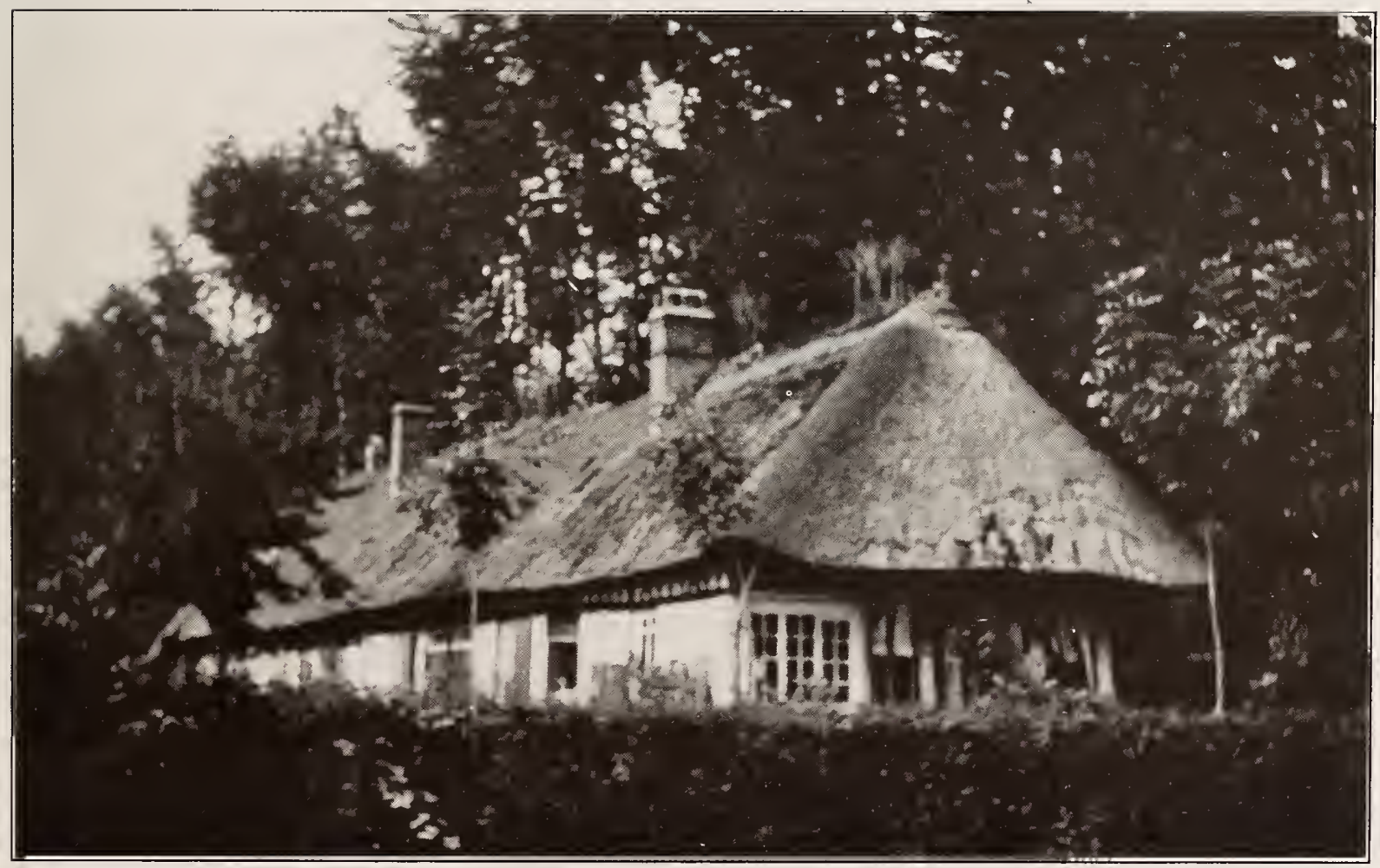

Plate I4. Cottage near Tôtes, Seine-Inférieure

A typical thatched-roof cottage of Normandy with hedge in the foreground and background of slender poplars 



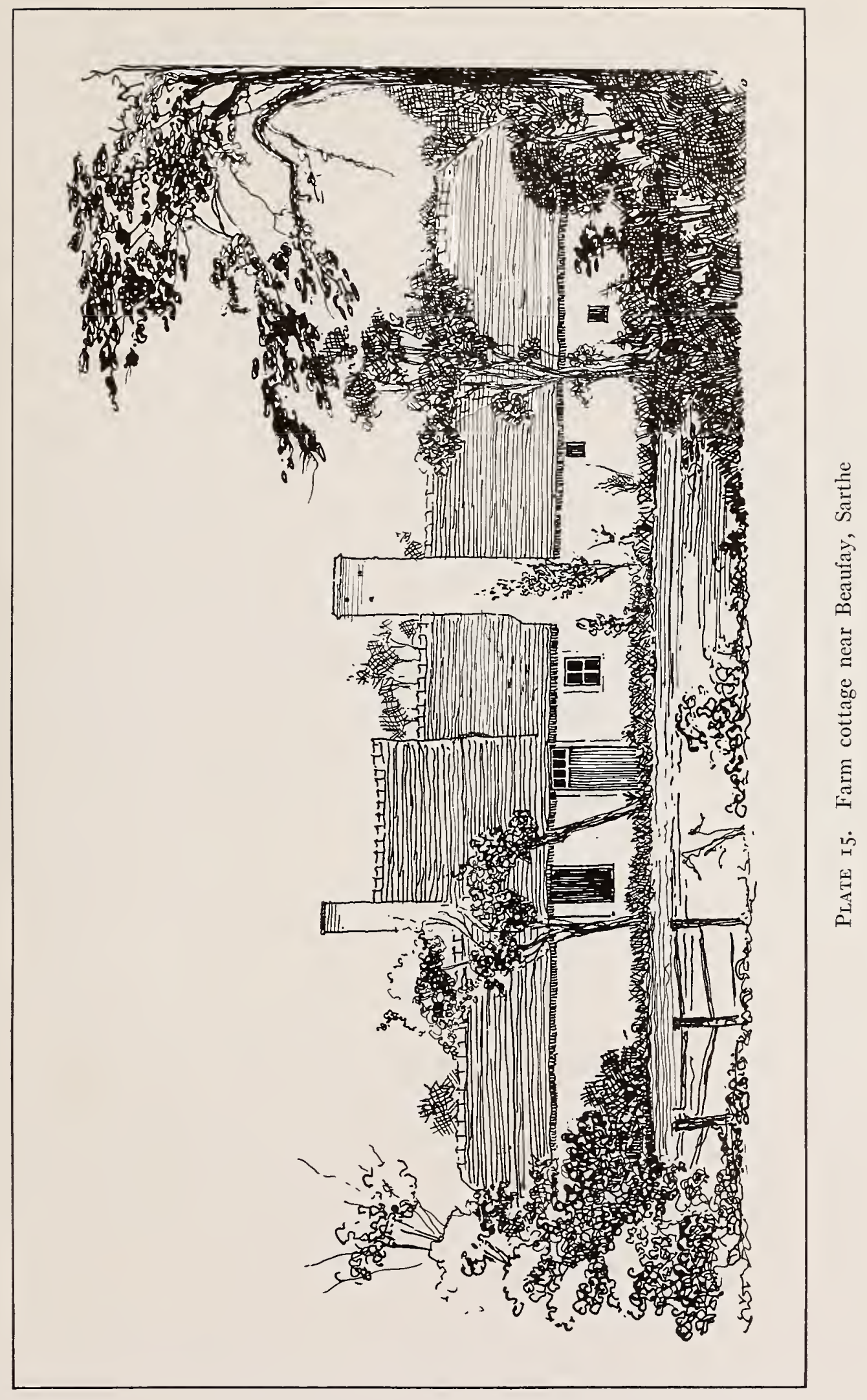





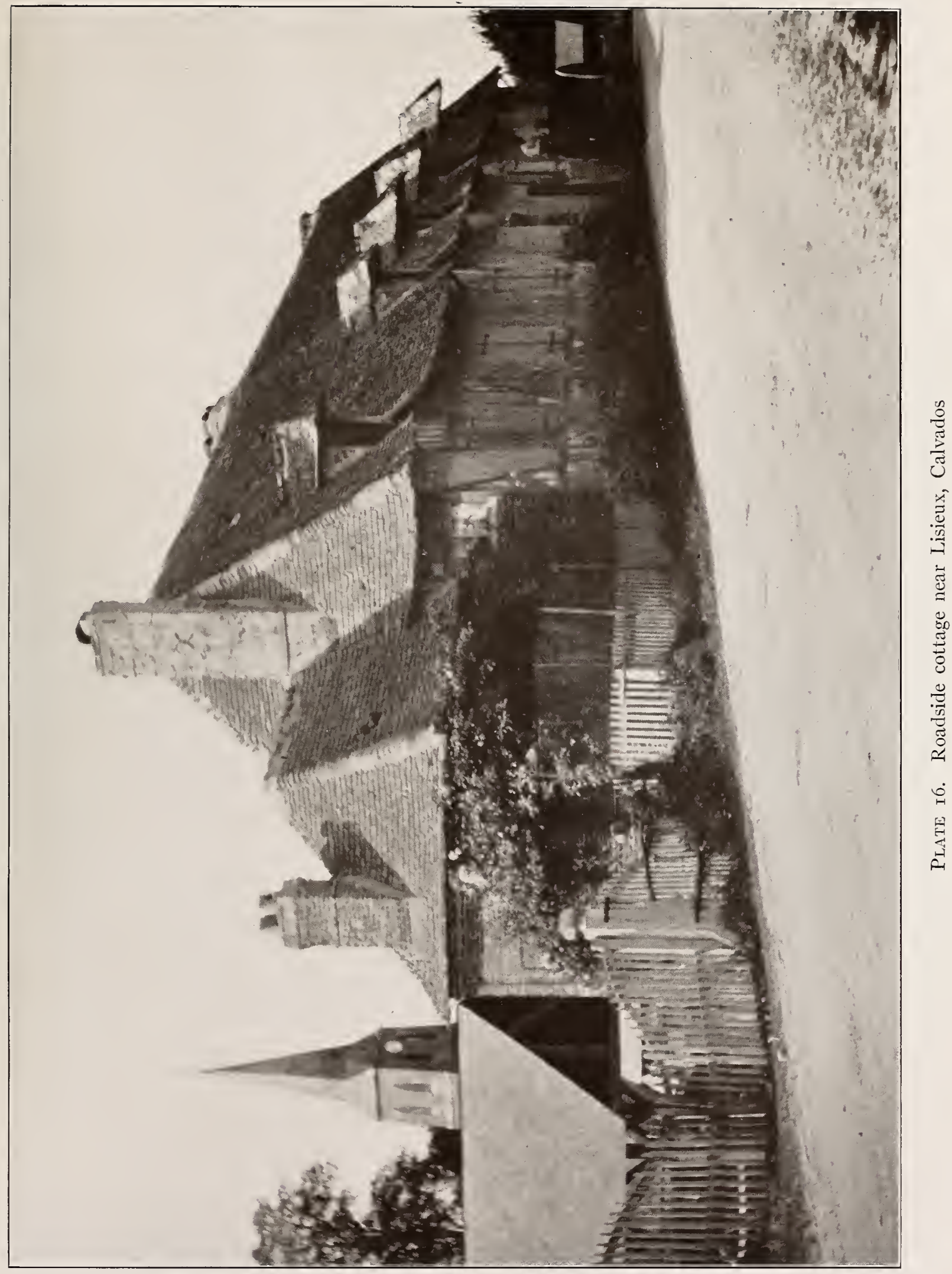





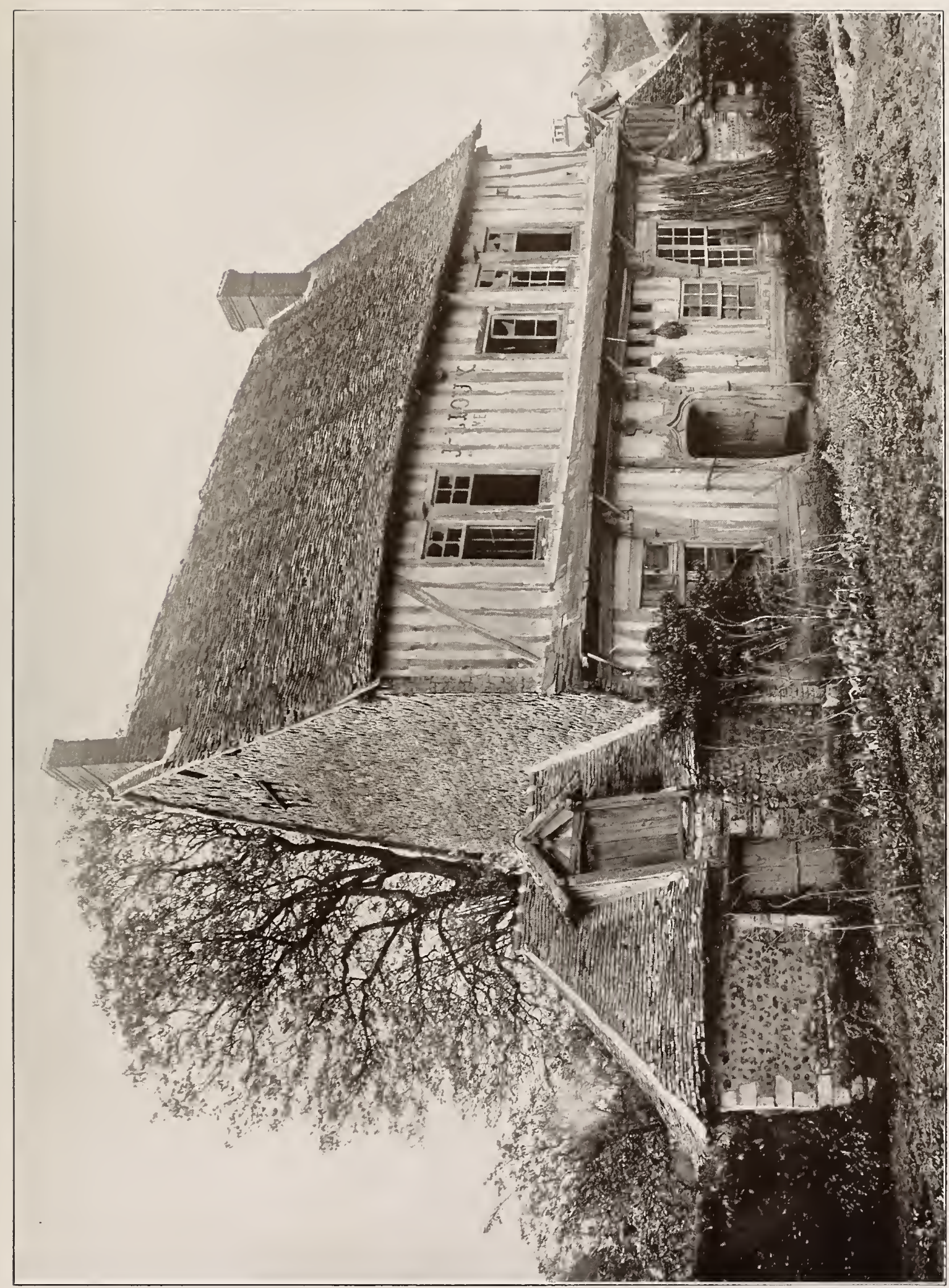

 



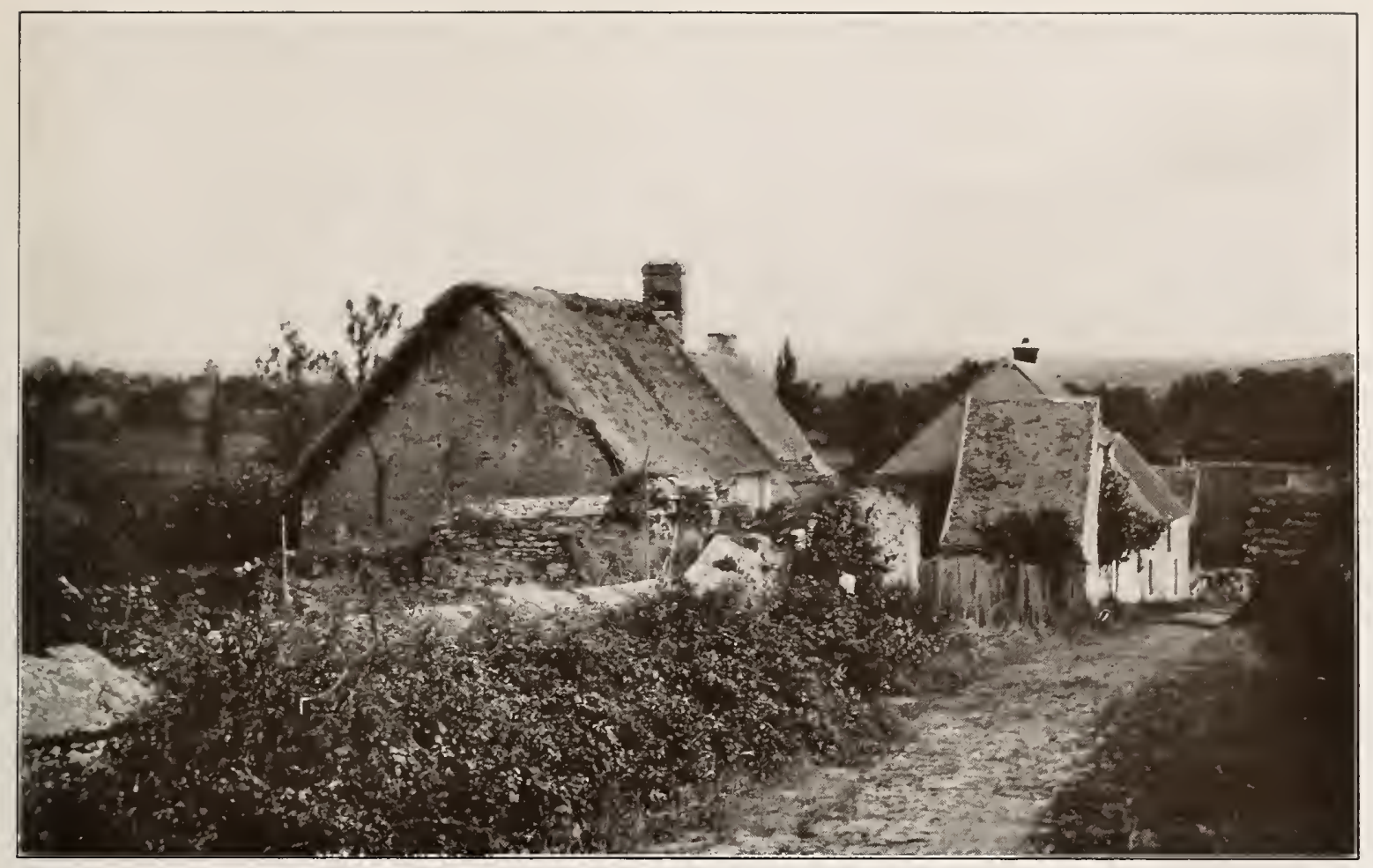

Plate i8. Hamlet near L'Amaury, Seine-et-Oise

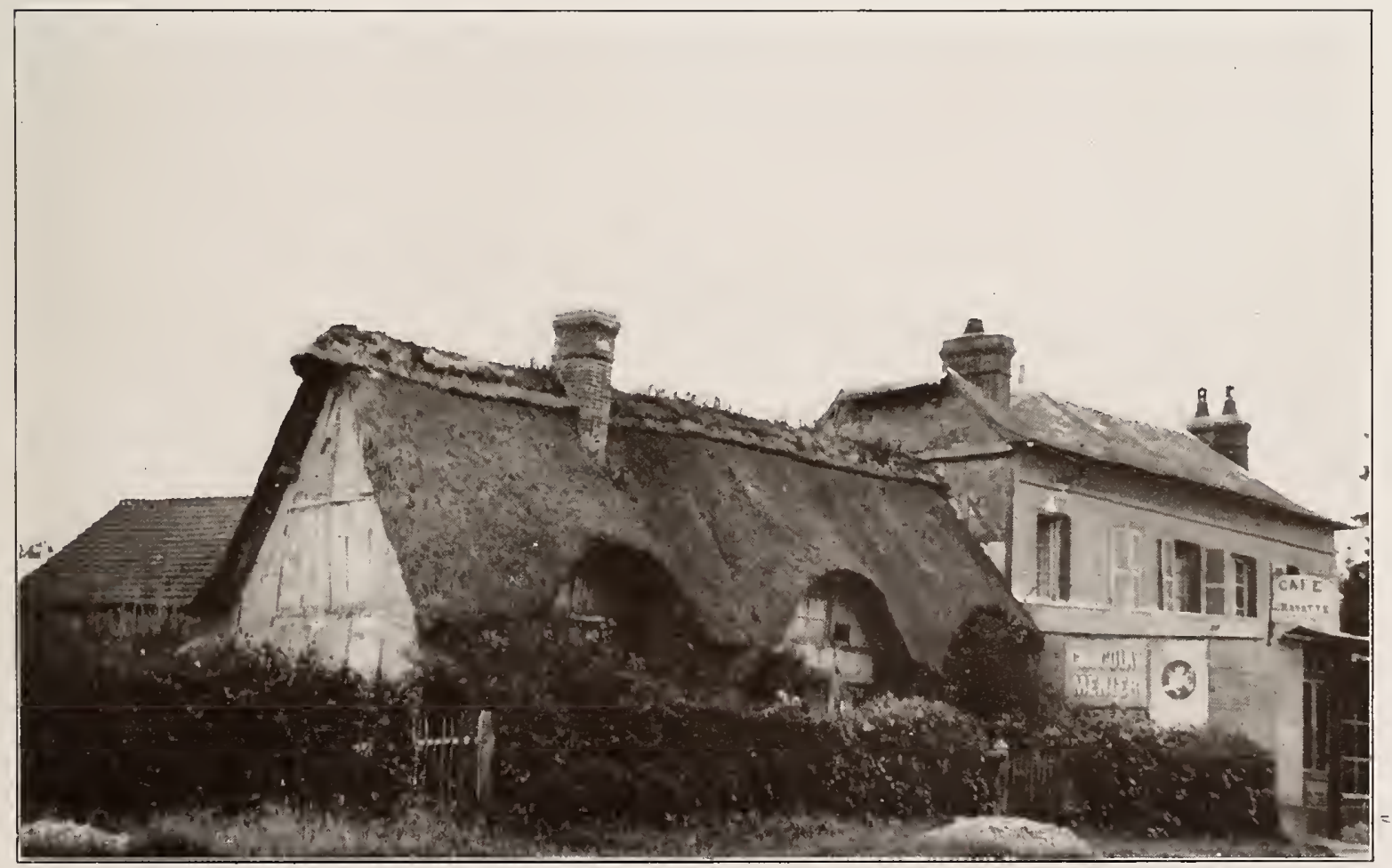

Plate I9. Cottage near Amfreville, Eure 



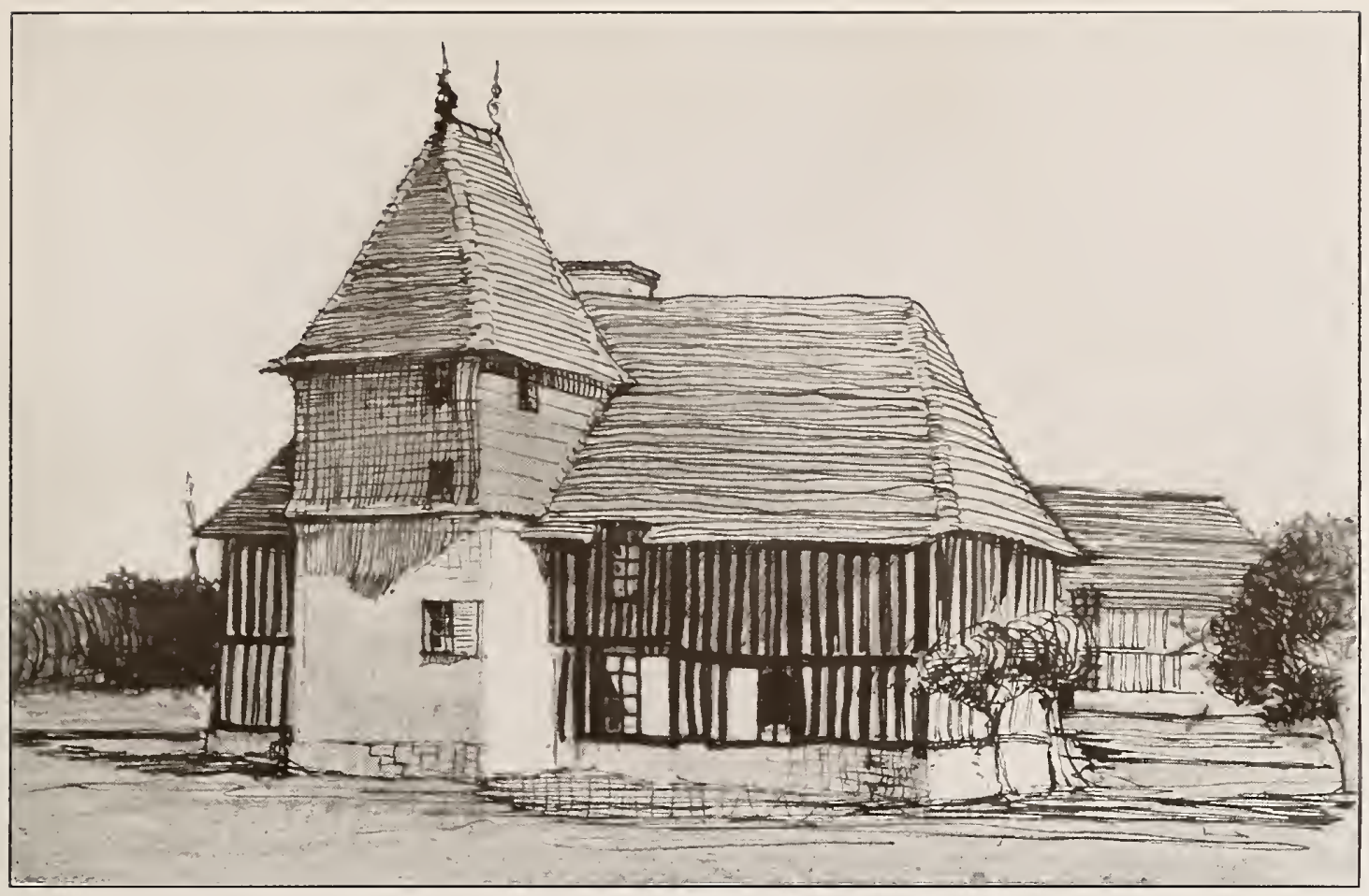

Plate 20. Farm at Bieville-en-Ange, Calvados

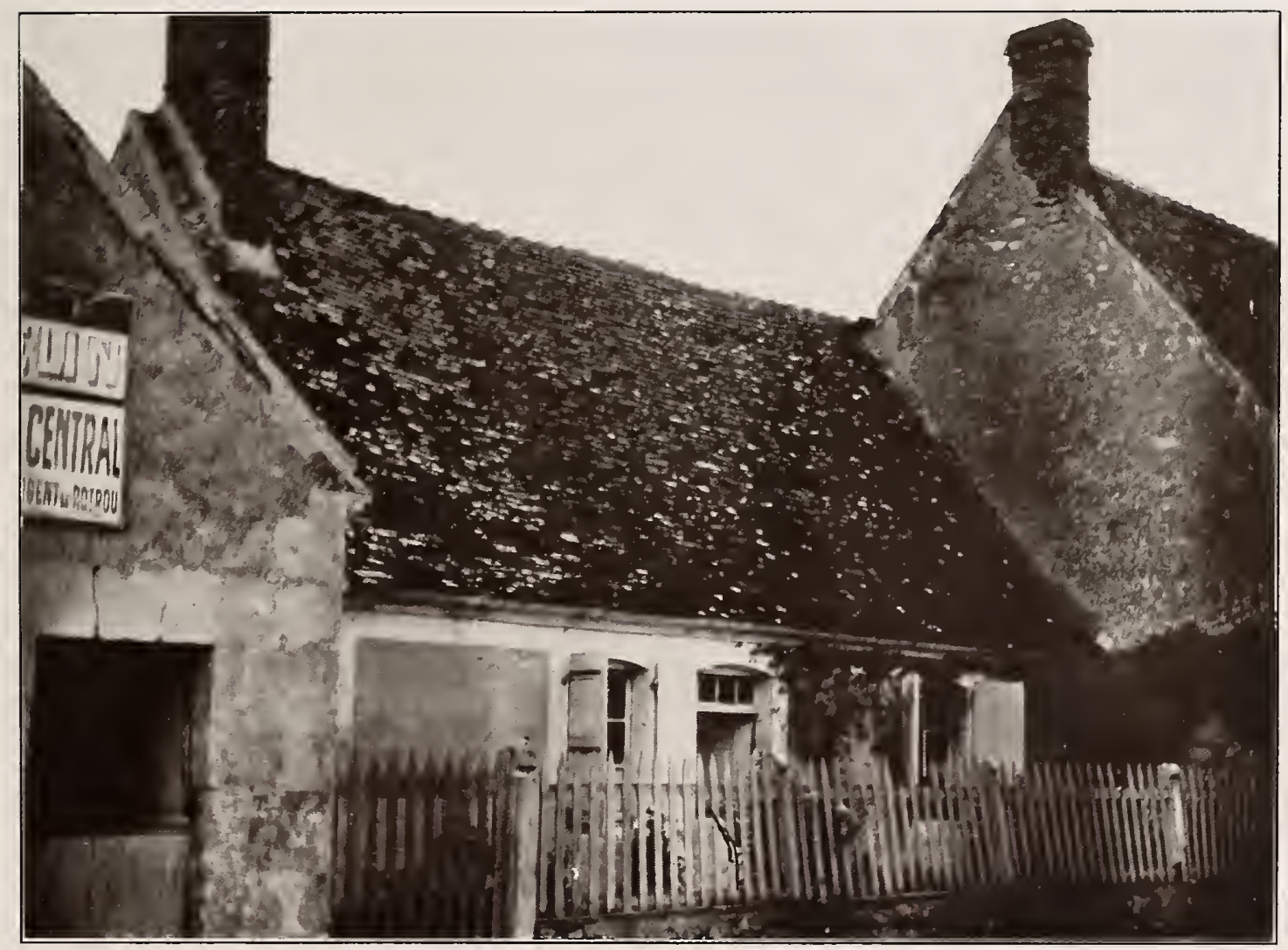

Plate 2r. Roadside cottage near Authon, Eure-et-Loir 



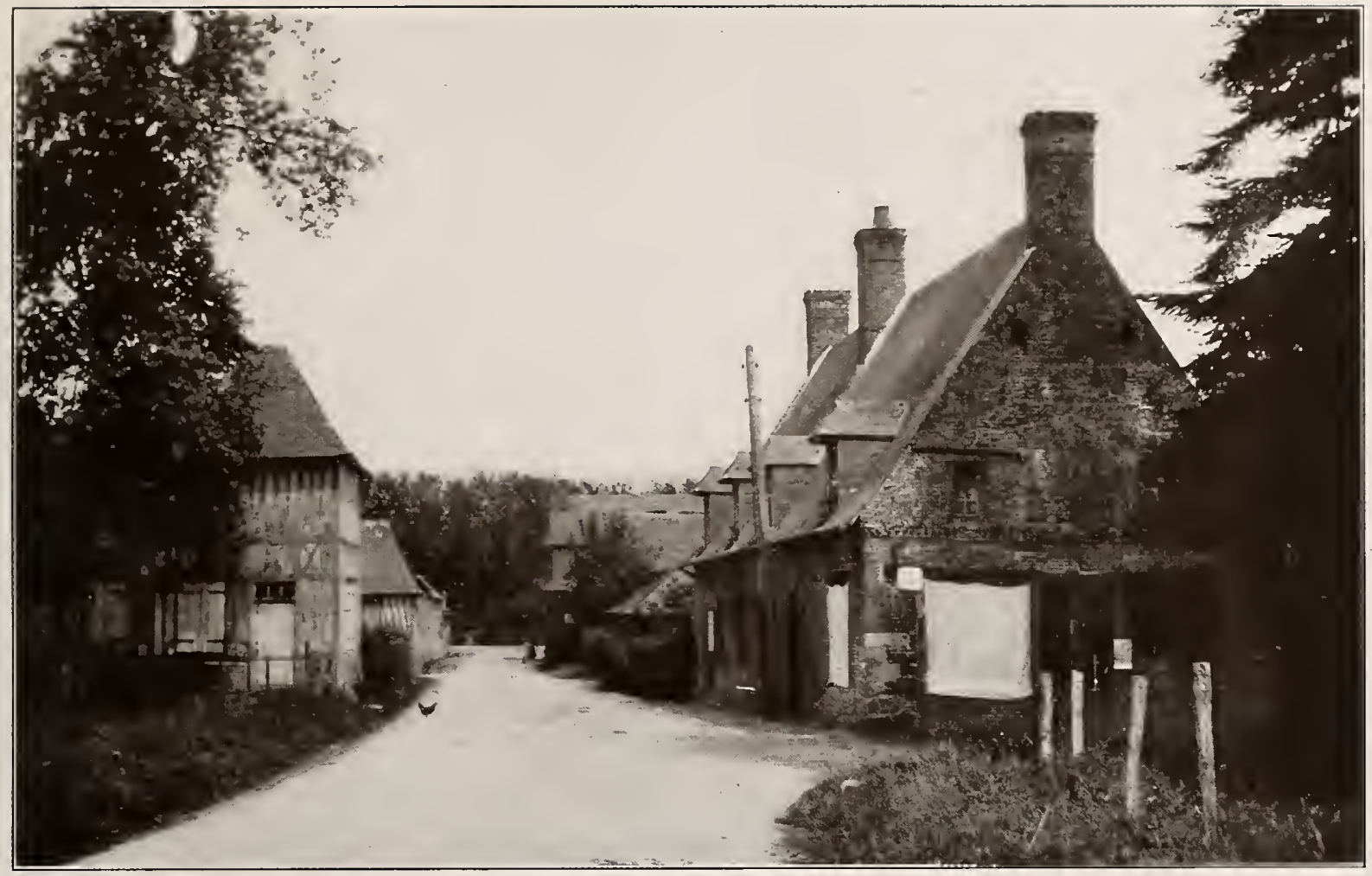

Plate 22. Hamlet near Yerville, Seine Inférieure

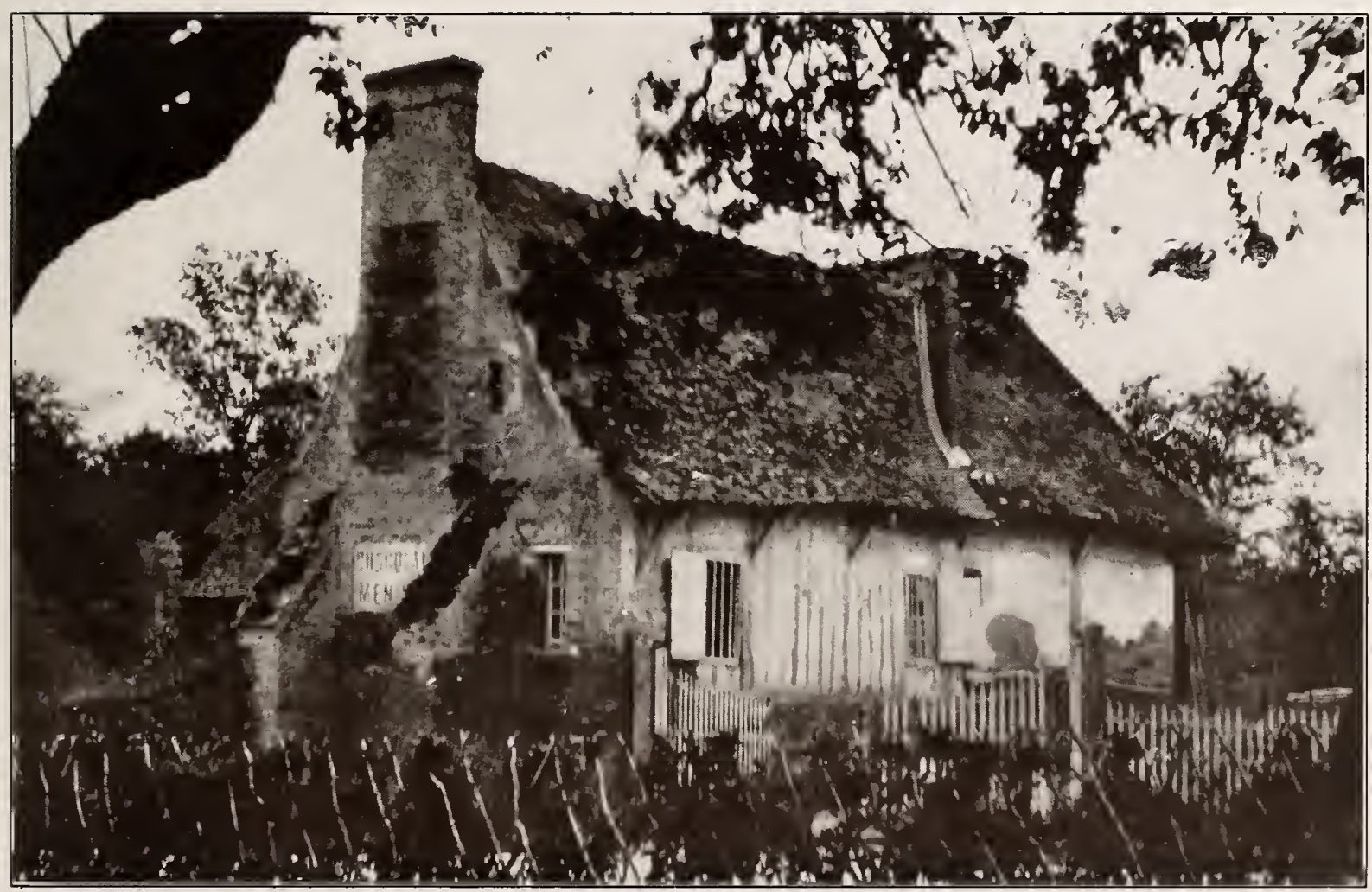

Plate 23. Cottage near Quiévercourt, Seine Inférieure 



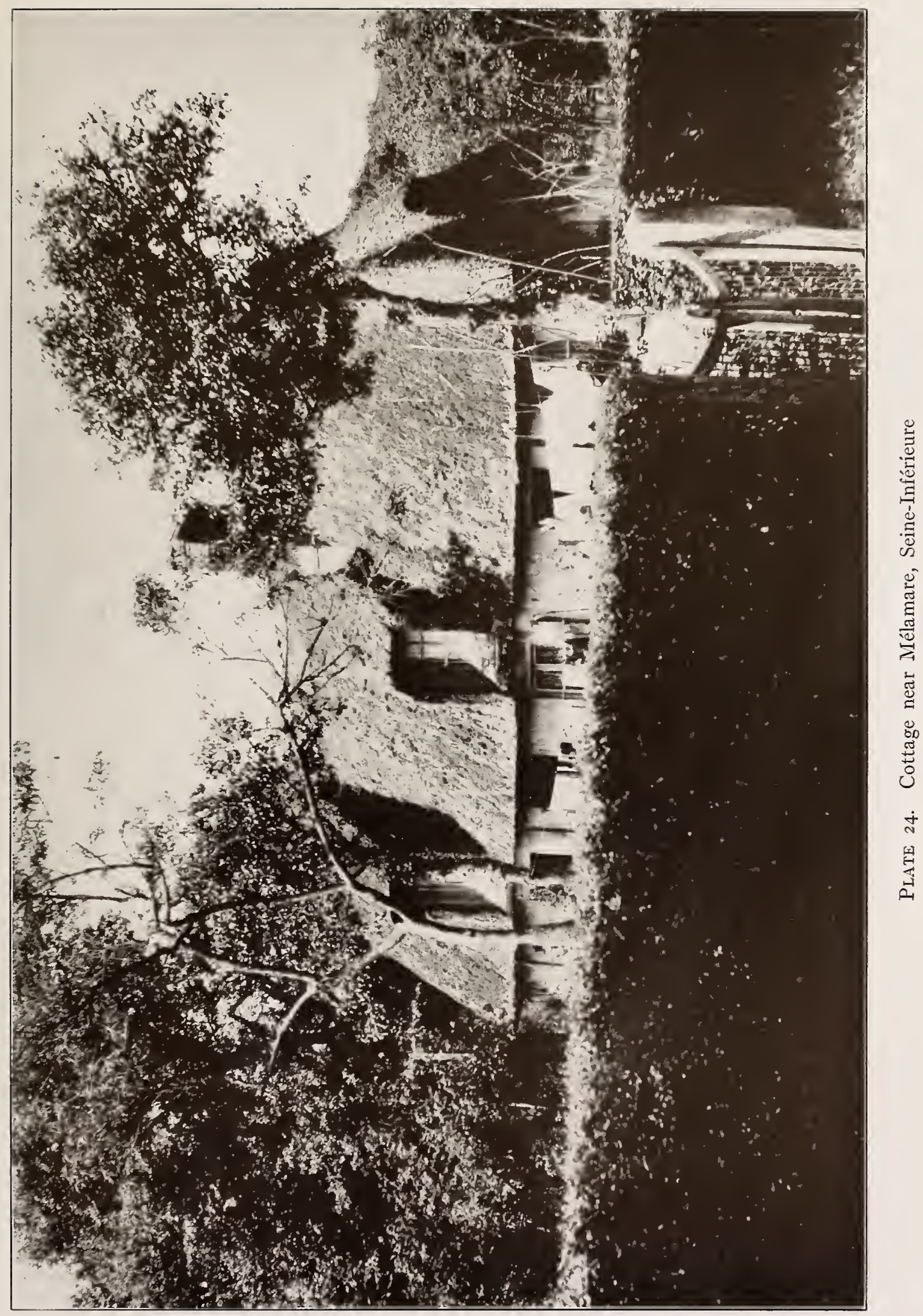





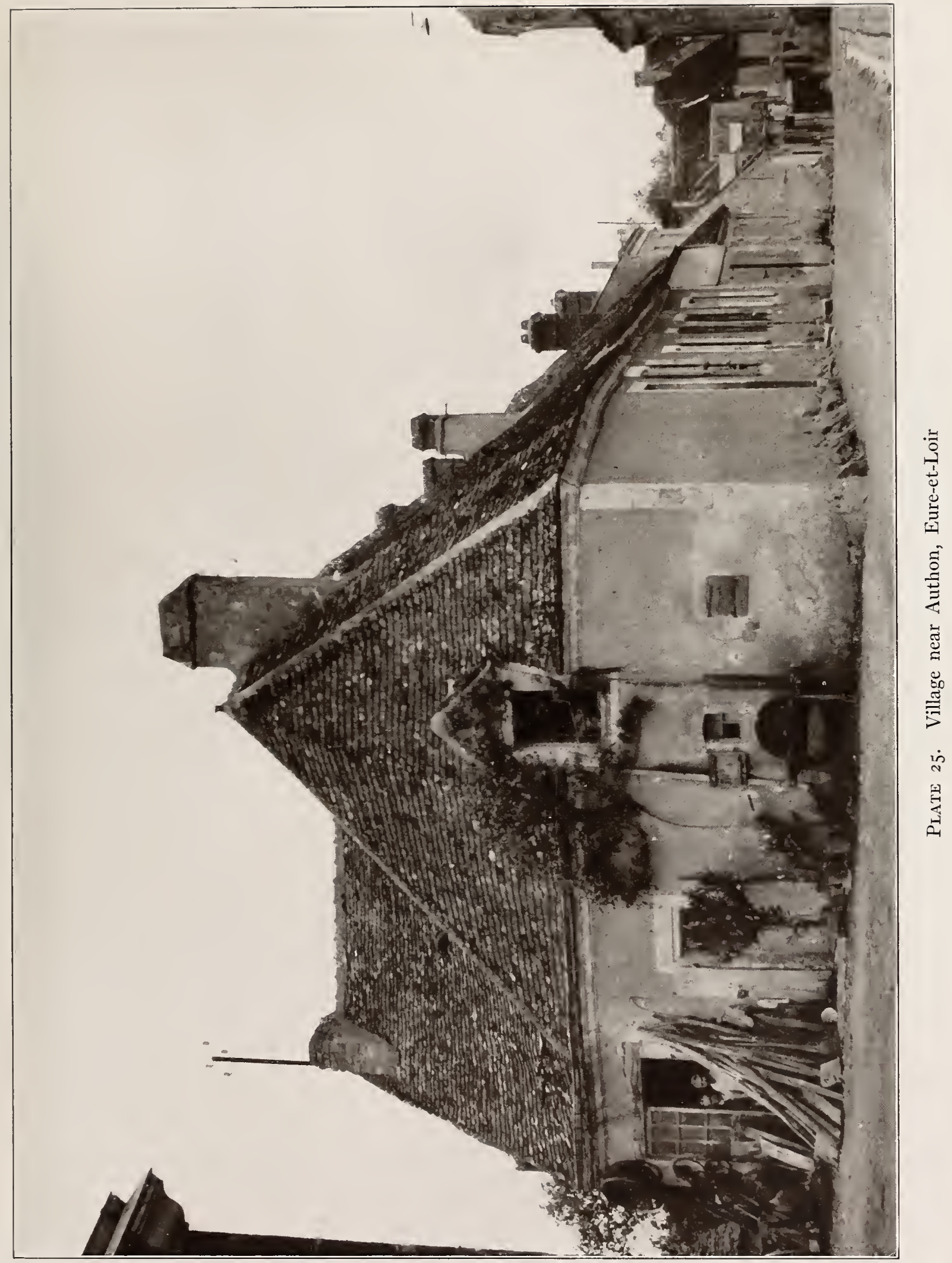





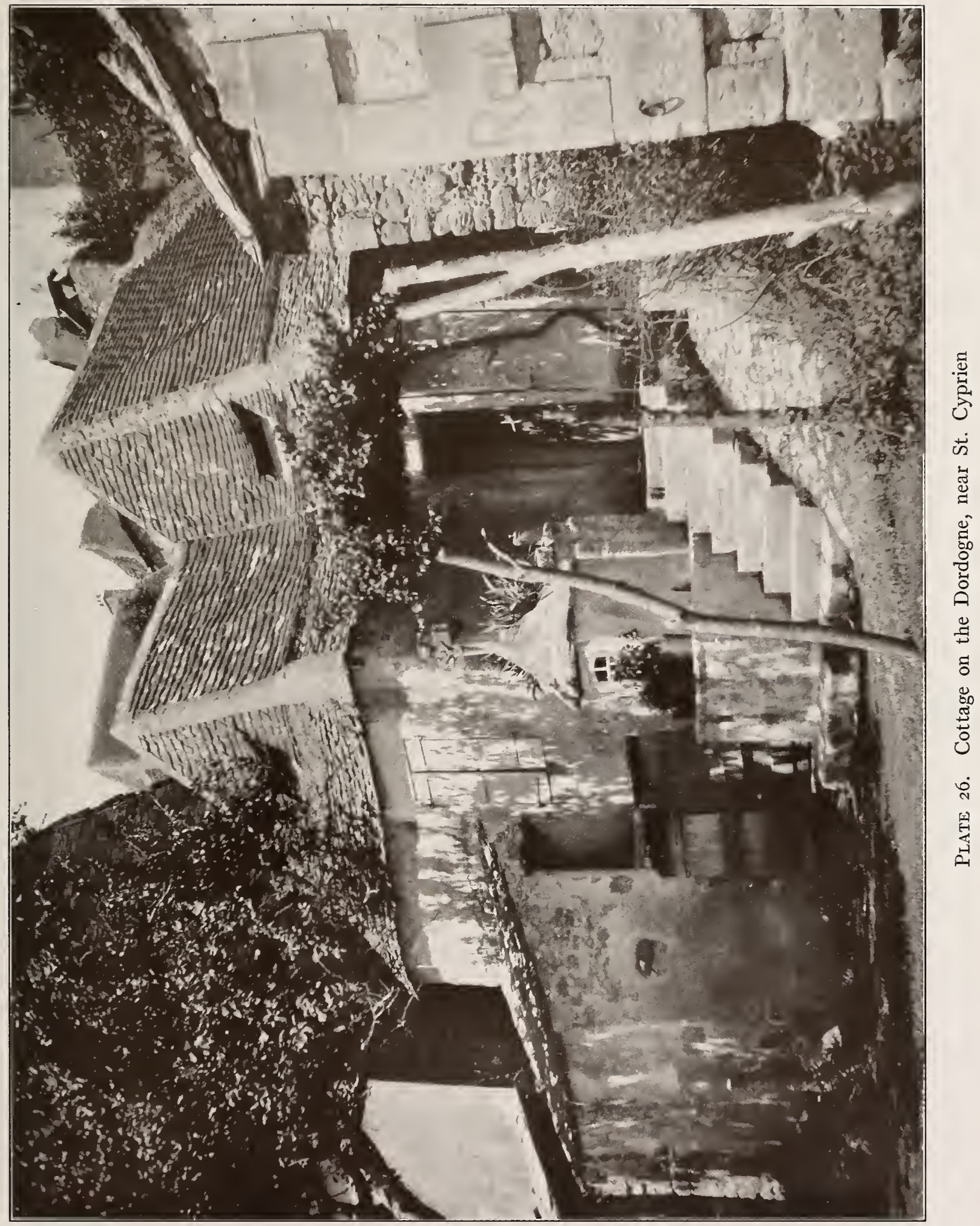





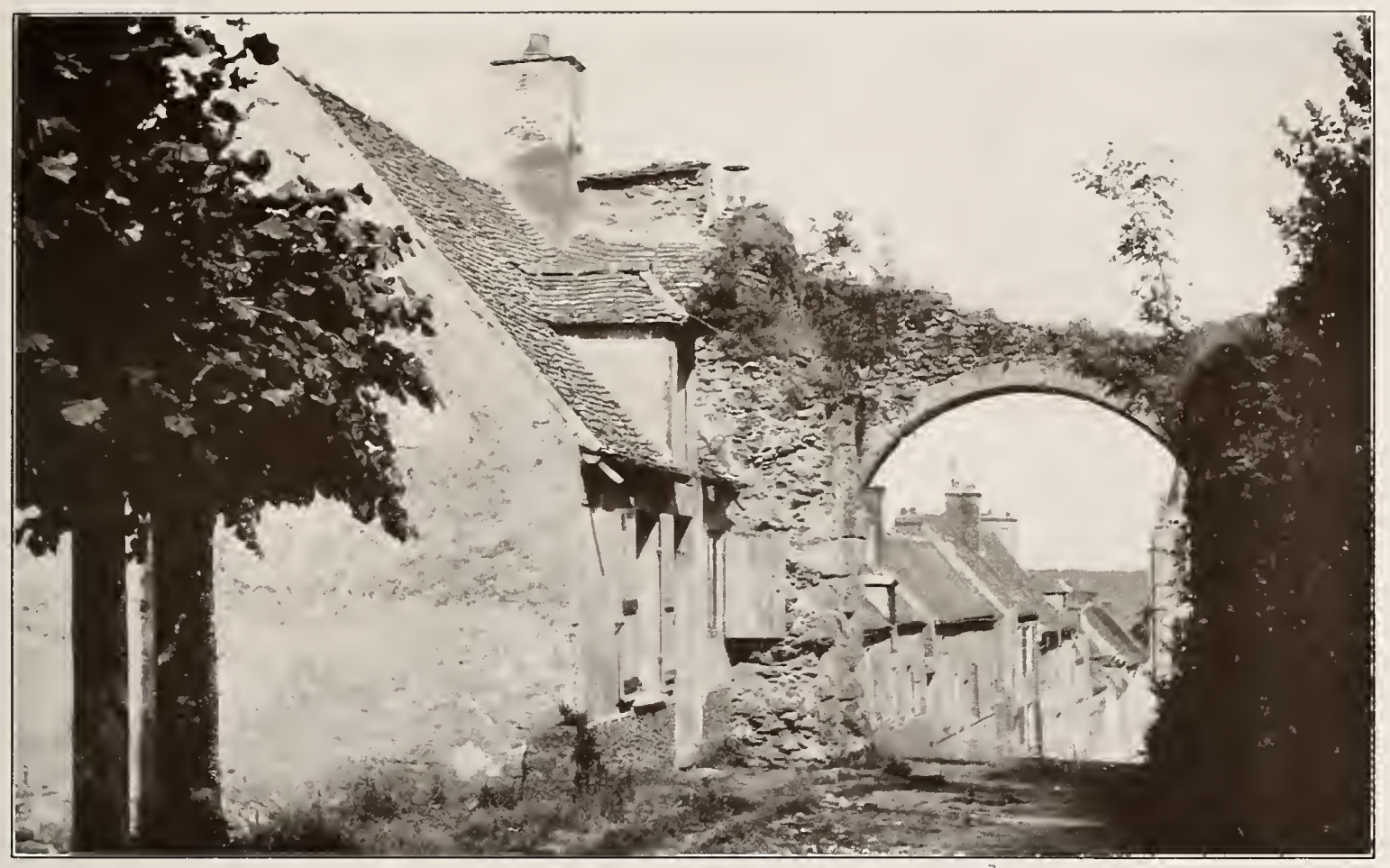

Plate 27. An entrance to Montfort, Seine-et-Oise

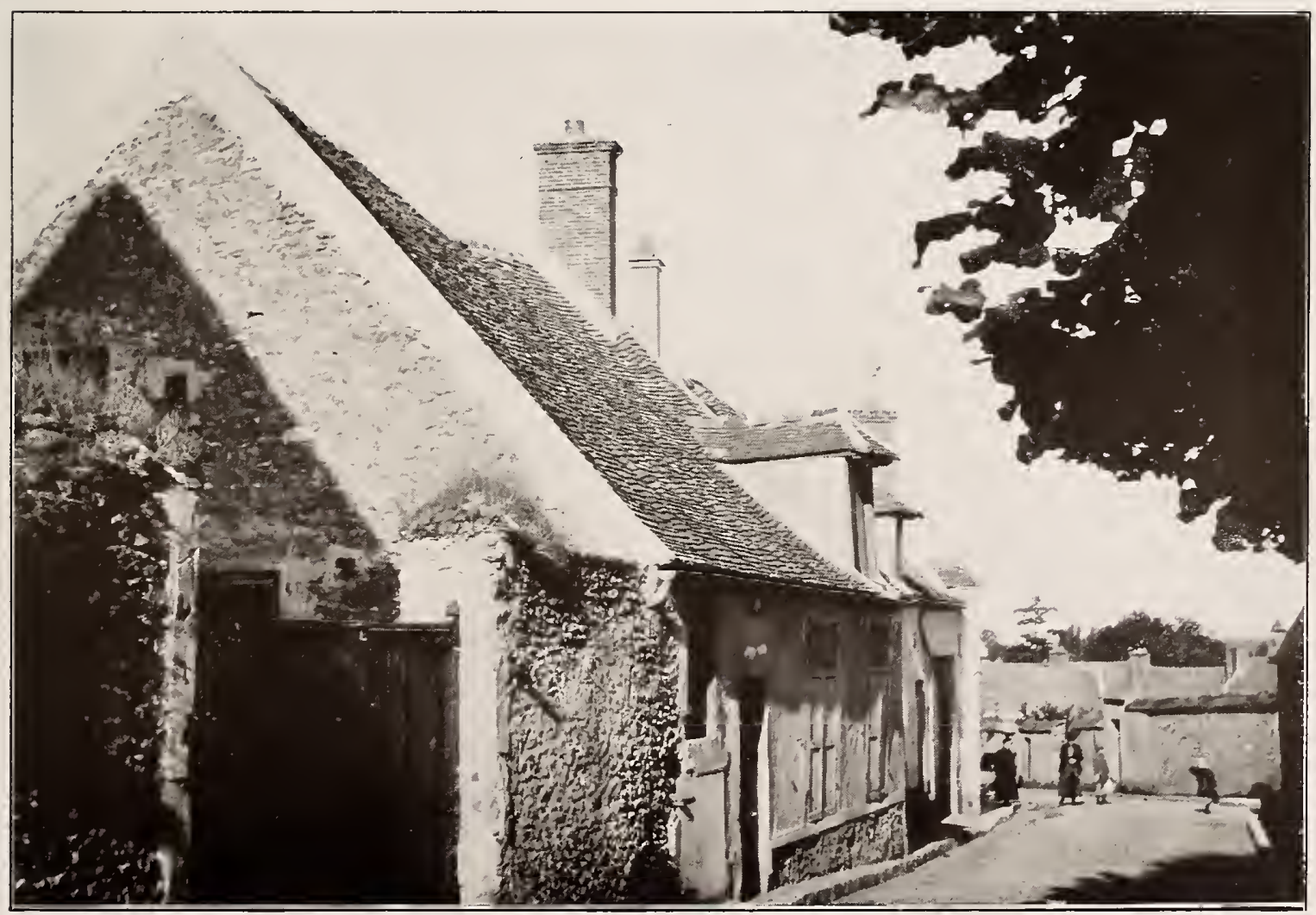

Plate 28. Village street, Montfort, Seine-et-Oise 



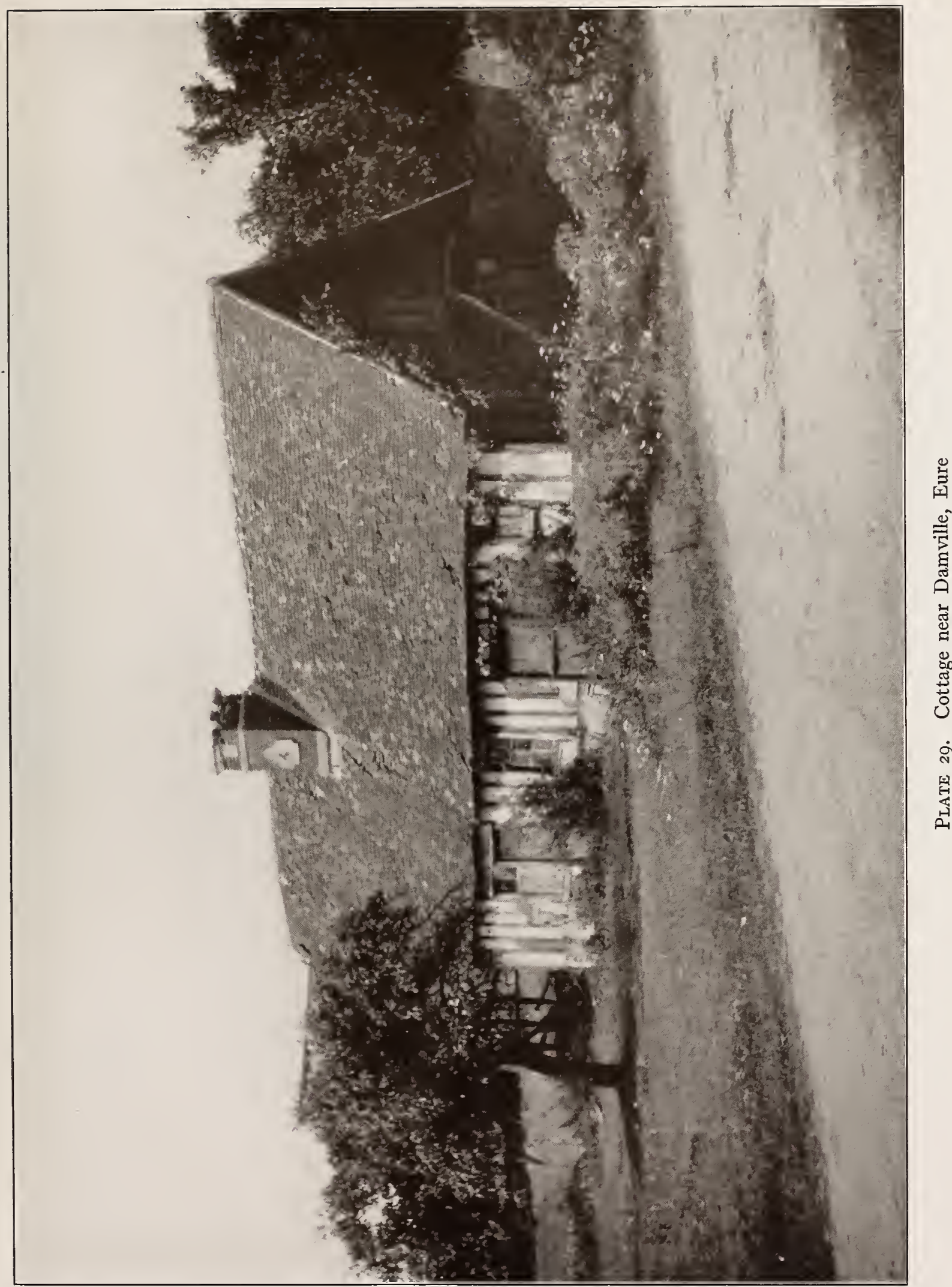





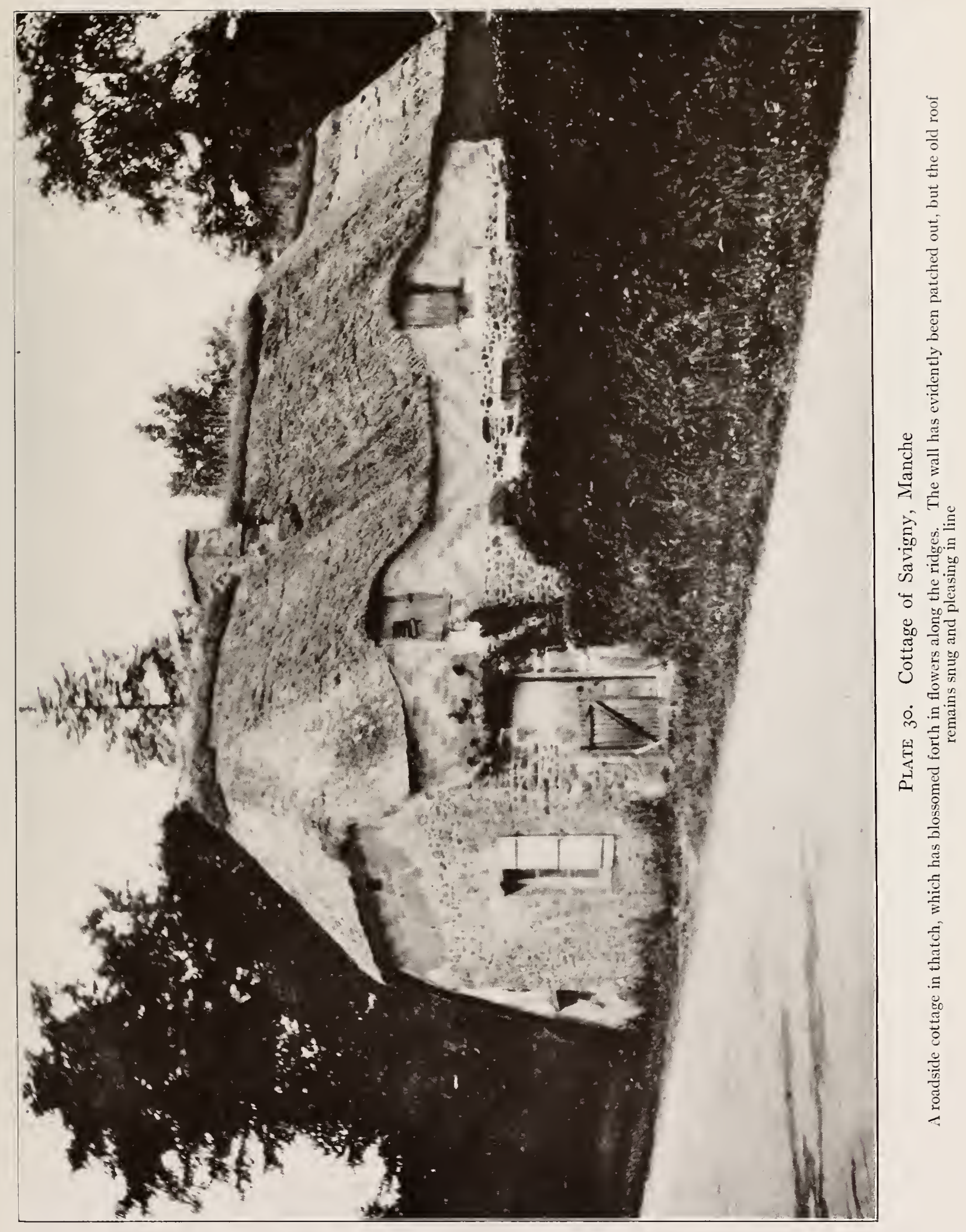





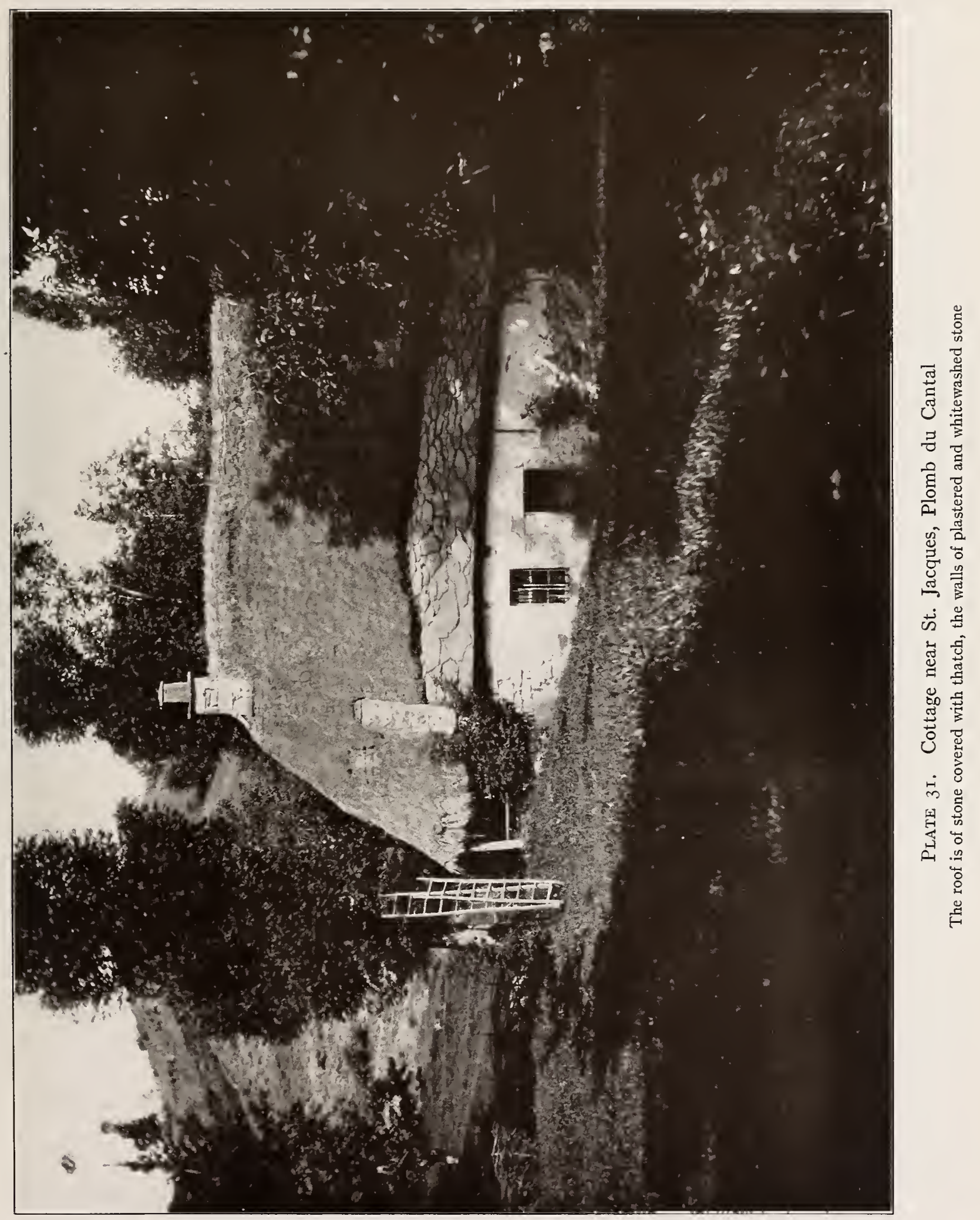





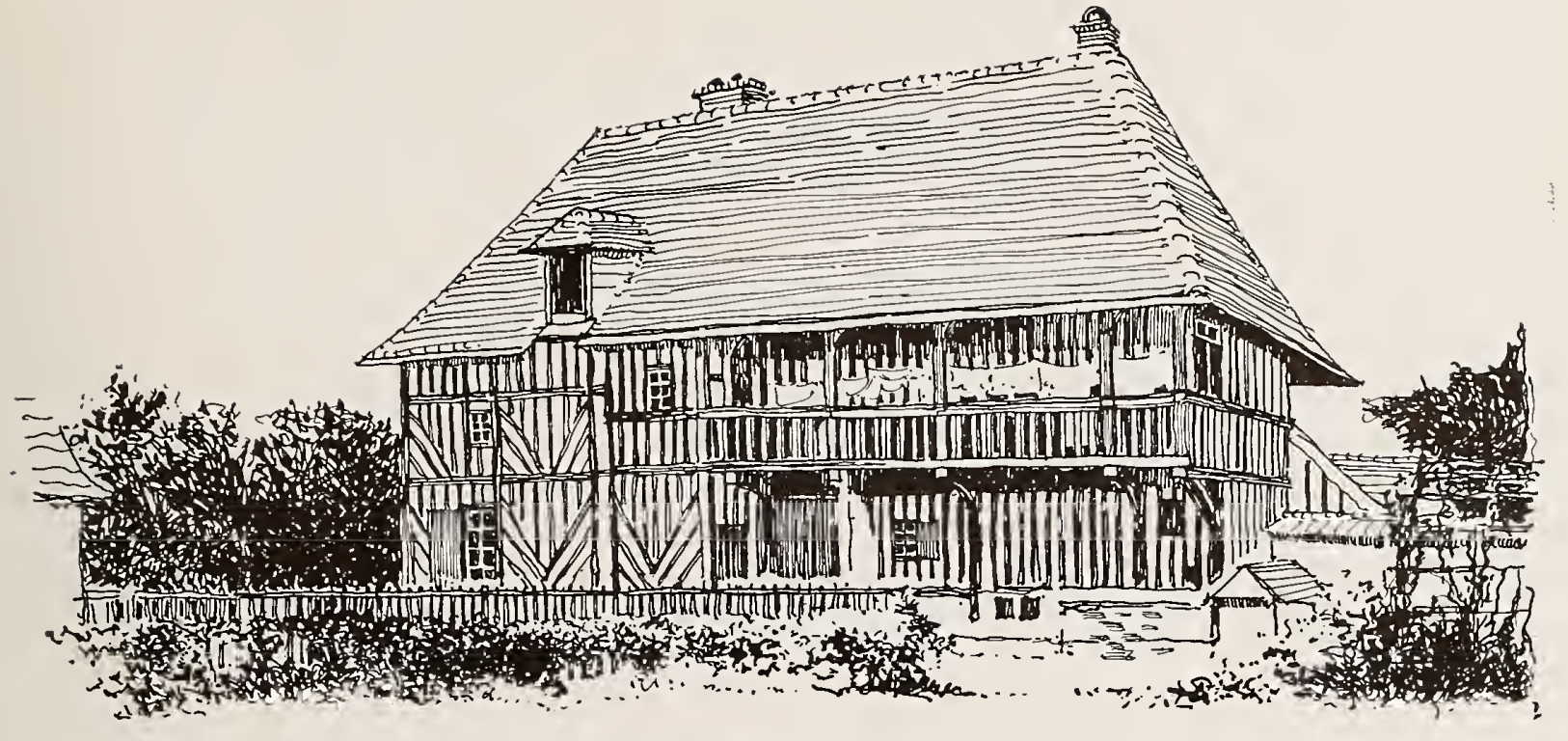

Plate 32. Farmhouse at Marolles, Calvados

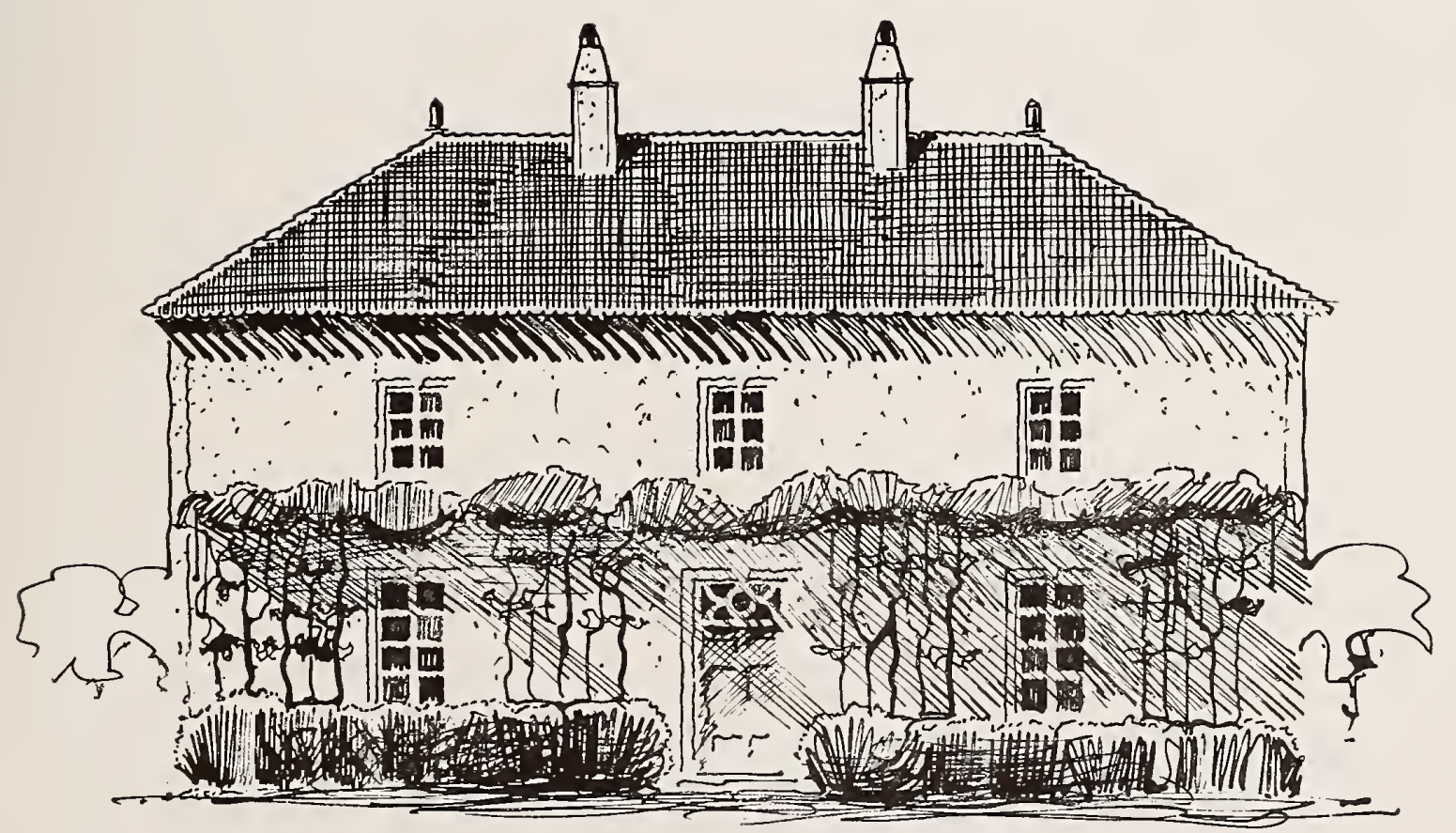

Plate 33. House in the Dordogne Valley 



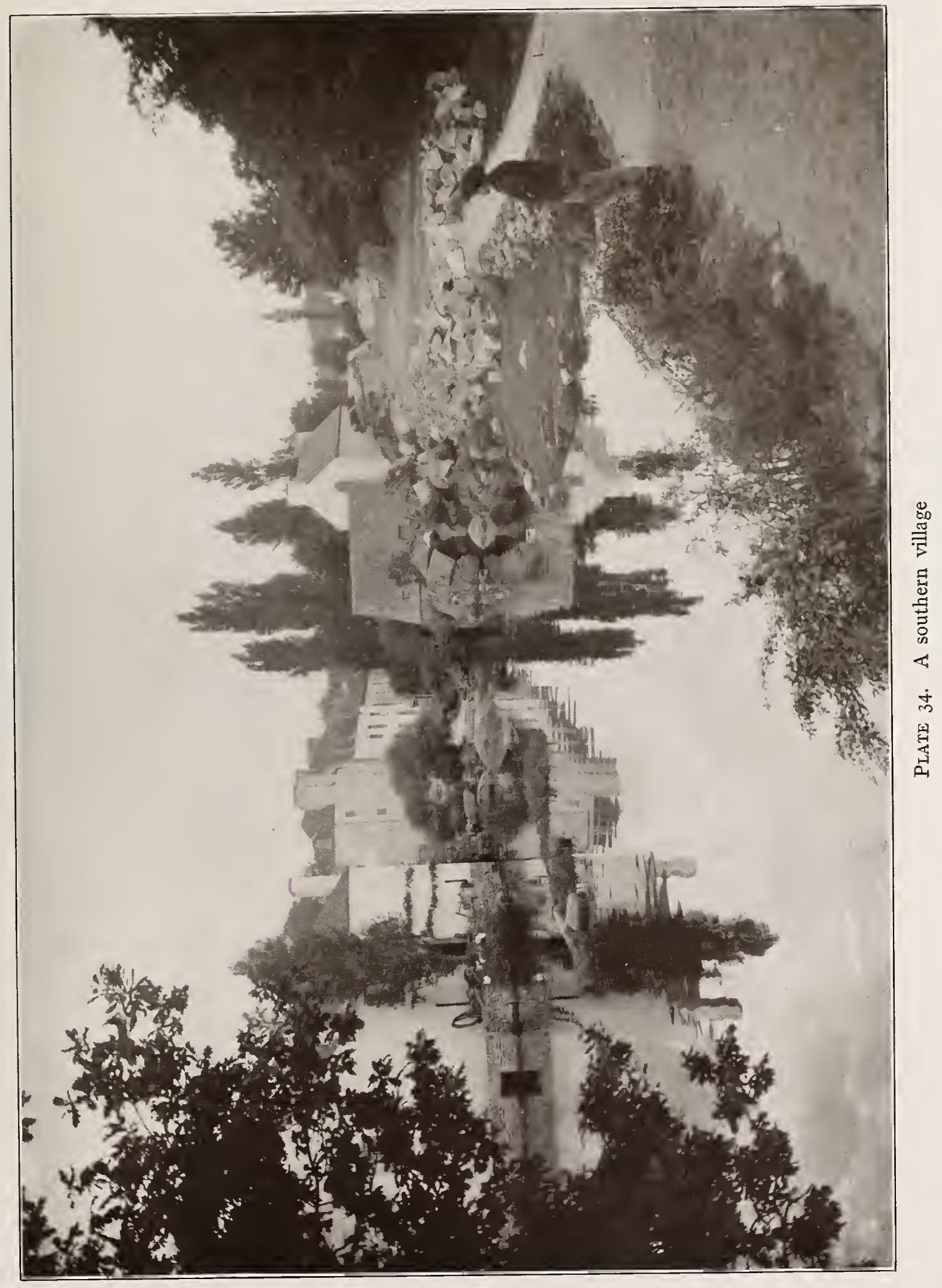





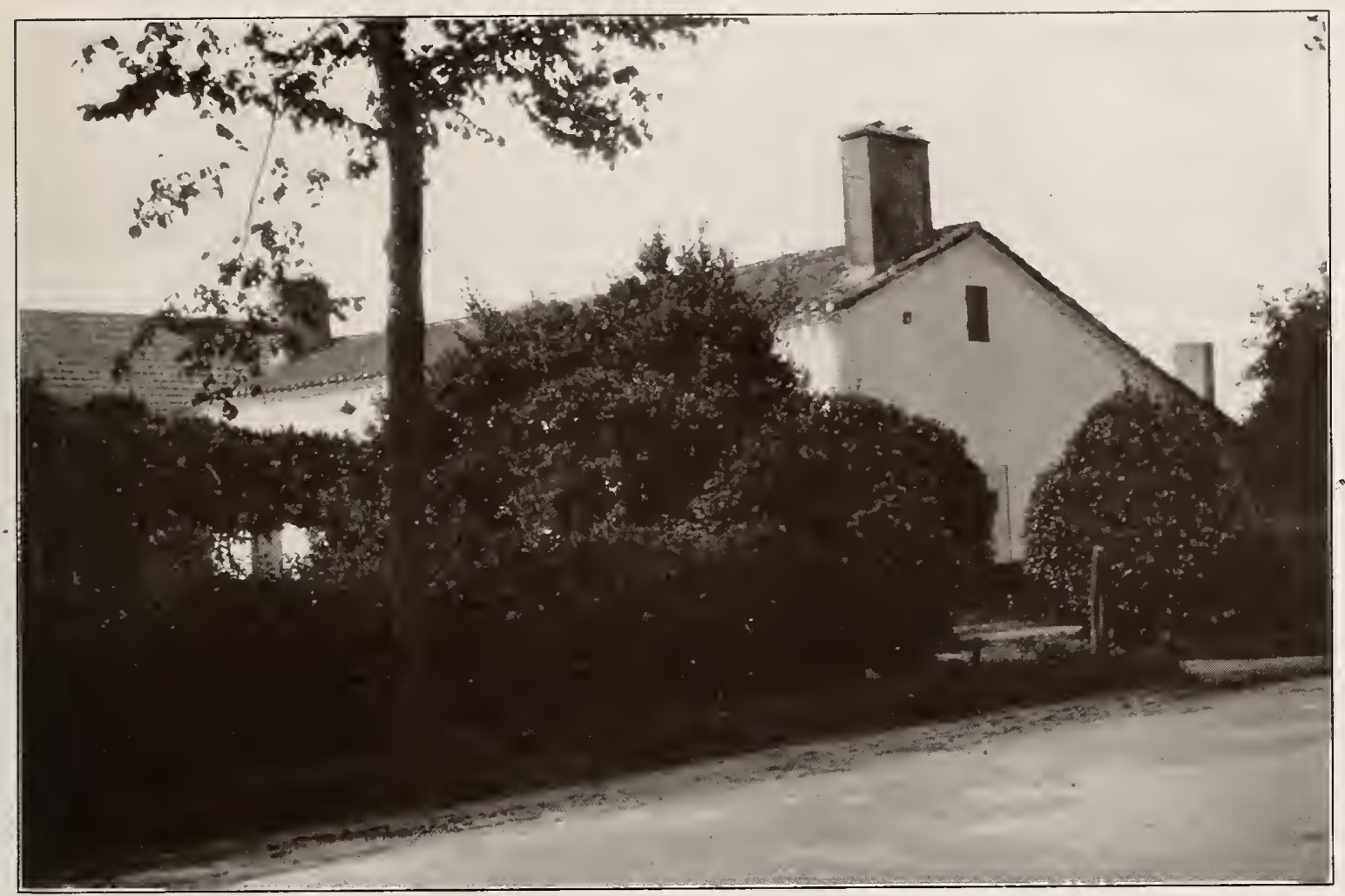

Plate 35. Cottage near Ste. Foy-la-Grande, Gironde

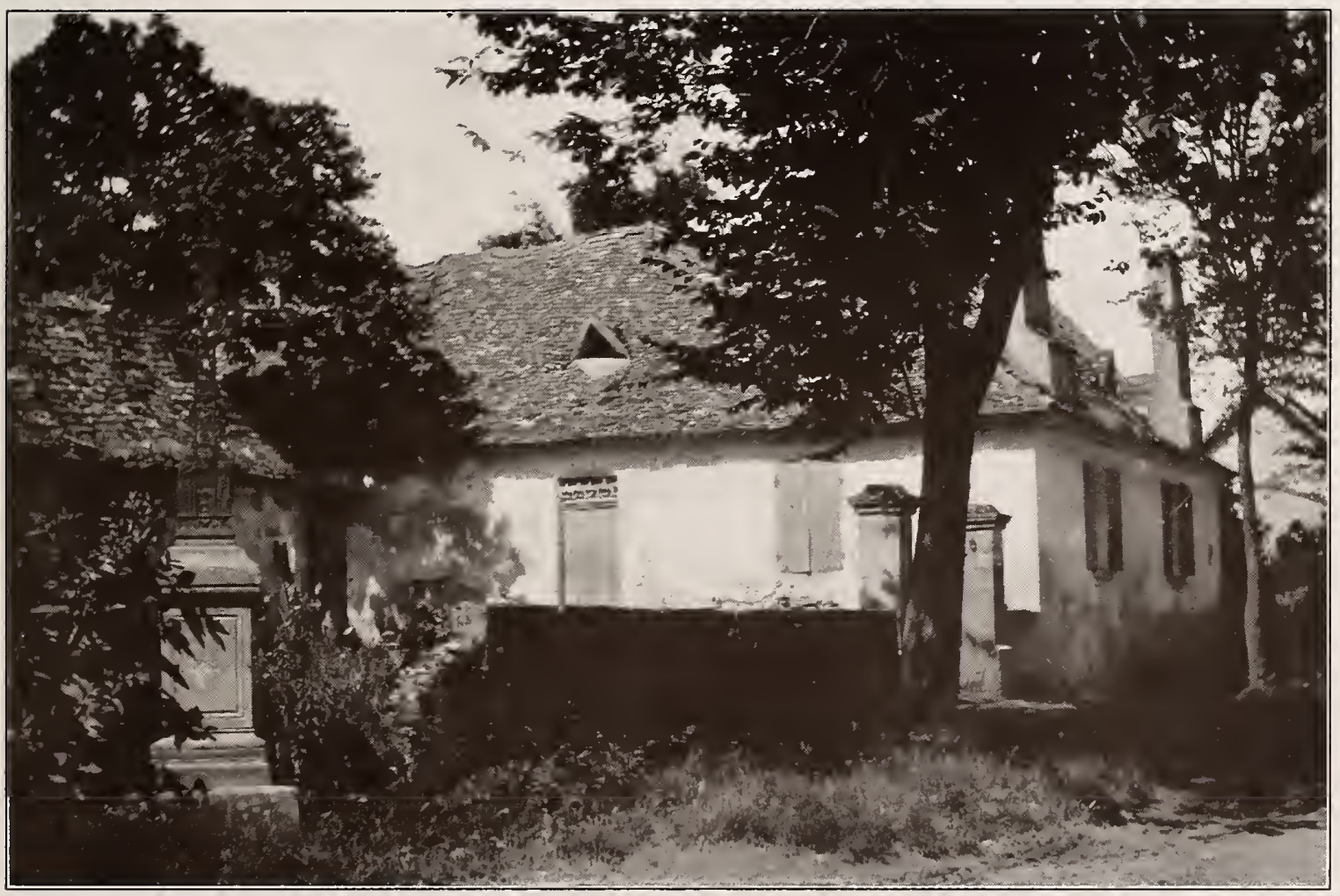

Plate 36. Cottage near Bergerac, Dordogne 



\section{H U R C H S A N D C H A P E L S}

SOMEIVHere in the vicinity of the chatteaux of France there grew up villages where lived the peasants dependent on the great families for their hire. The chapel or church was built to fill the needs of these little communities and the surrounding district, sometimes forming one of the buildings of the château group proper, or else being near by at the cross-roads in the château hamlet.

A Normandy type, of which Plates 38,42 , and 45 are good examples, is particularly interesting for gabled towers, a treatment capable of excellent and variable proportions. The tower of the chapel near Brécy has a chunky, solid shape, that at Vaucelle a feeling of more taper and grace, while the tower of the chapel at Gratot reaches up to the sky like a lofty sentinel. The towers are placed at different points on the plans, over the crossing, astride the ridge, and at the entrance. Other examples would show the same freedom and variety. It is interesting to note the impressiveness of these simple towers and their grace of line, the latter due for the most part to the proper use of battered sides. The window openings are minimum even in the belfry, lending a solidity to the massive walls. The texture of the gray stone walls and their proportions seem to be of sufficient value to give them architectural excellence. The battering of the walls in most cases made buttresses unnecessary from a constructive standpoint.

The little chapel at Romorantin is very attractive in its setting, and in design represents simplicity itself; while the château chapel at Millançay, with its roundheaded, white-trimmed windows, and truly Georgian cupola, seems very suggestive of our buildings of the Georgian period.

Some stray influence created the church at Daoulas (Plate 43 ) with its very quaint and unusual gable and belfry of rather Belgian design. Plate 46 shows a very picturesque grouping of roofs-flat slate roofs with the roll-tile ridges. The interiors of these simple churches are not so worthy of comment. Except for the utter simplicity of their podged or plastered walls and the unadorned rafters and ties, grown gray with age, there is little to note. 



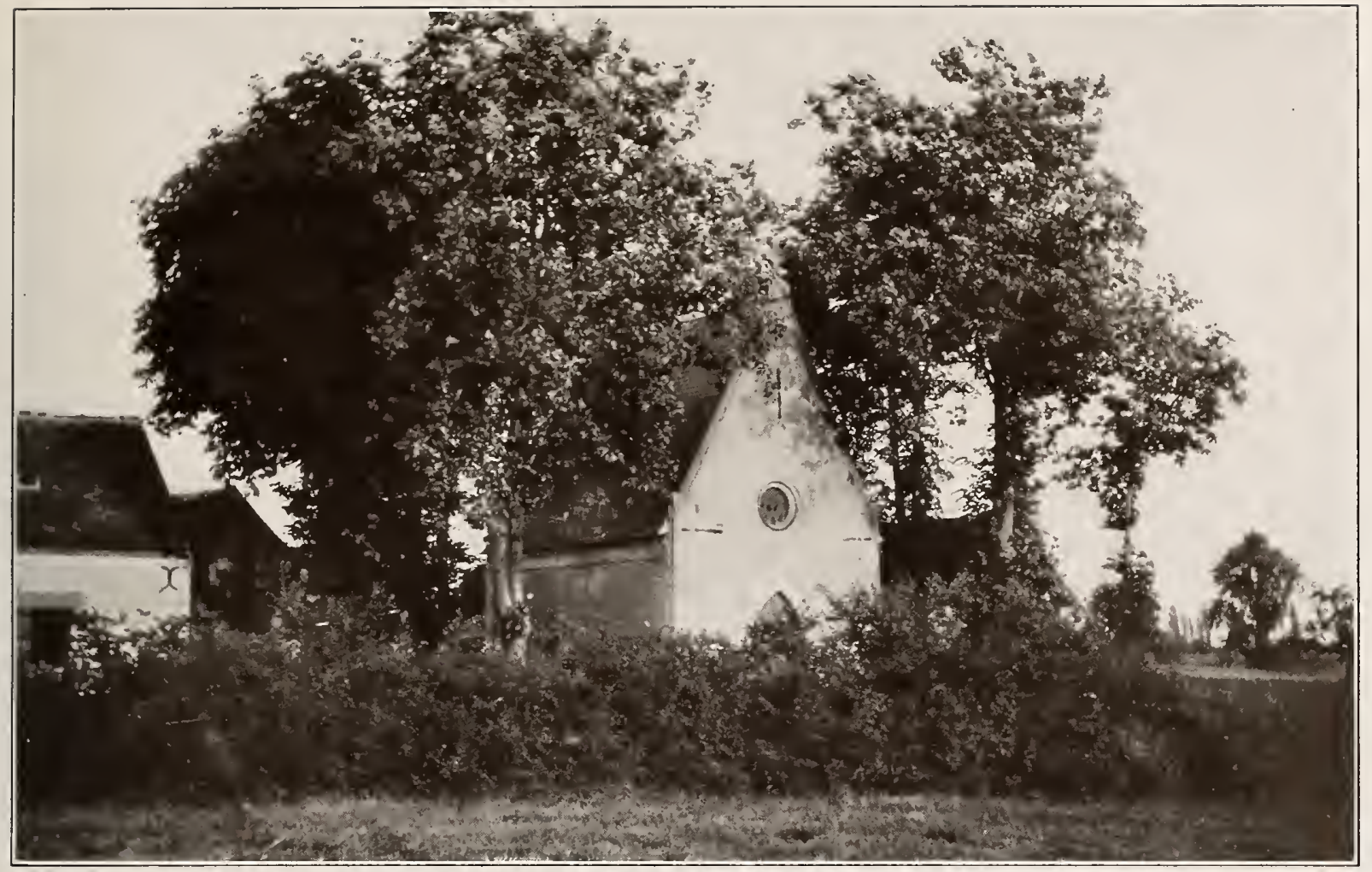

Plate 37. Chapel at Romorantin, Loir-et-Cher

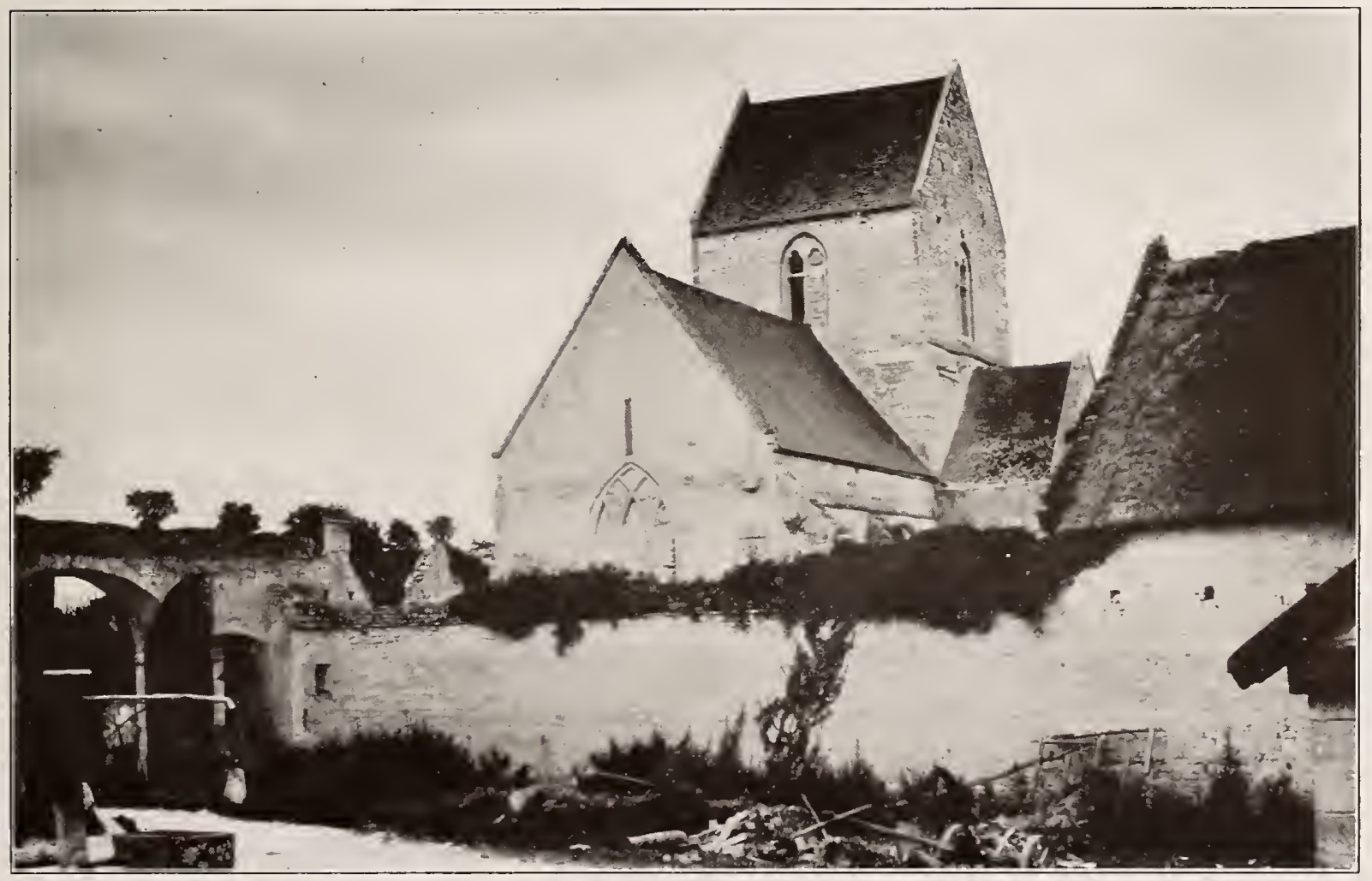

Plate 38. Farm chapel near Brécy, Calvados 


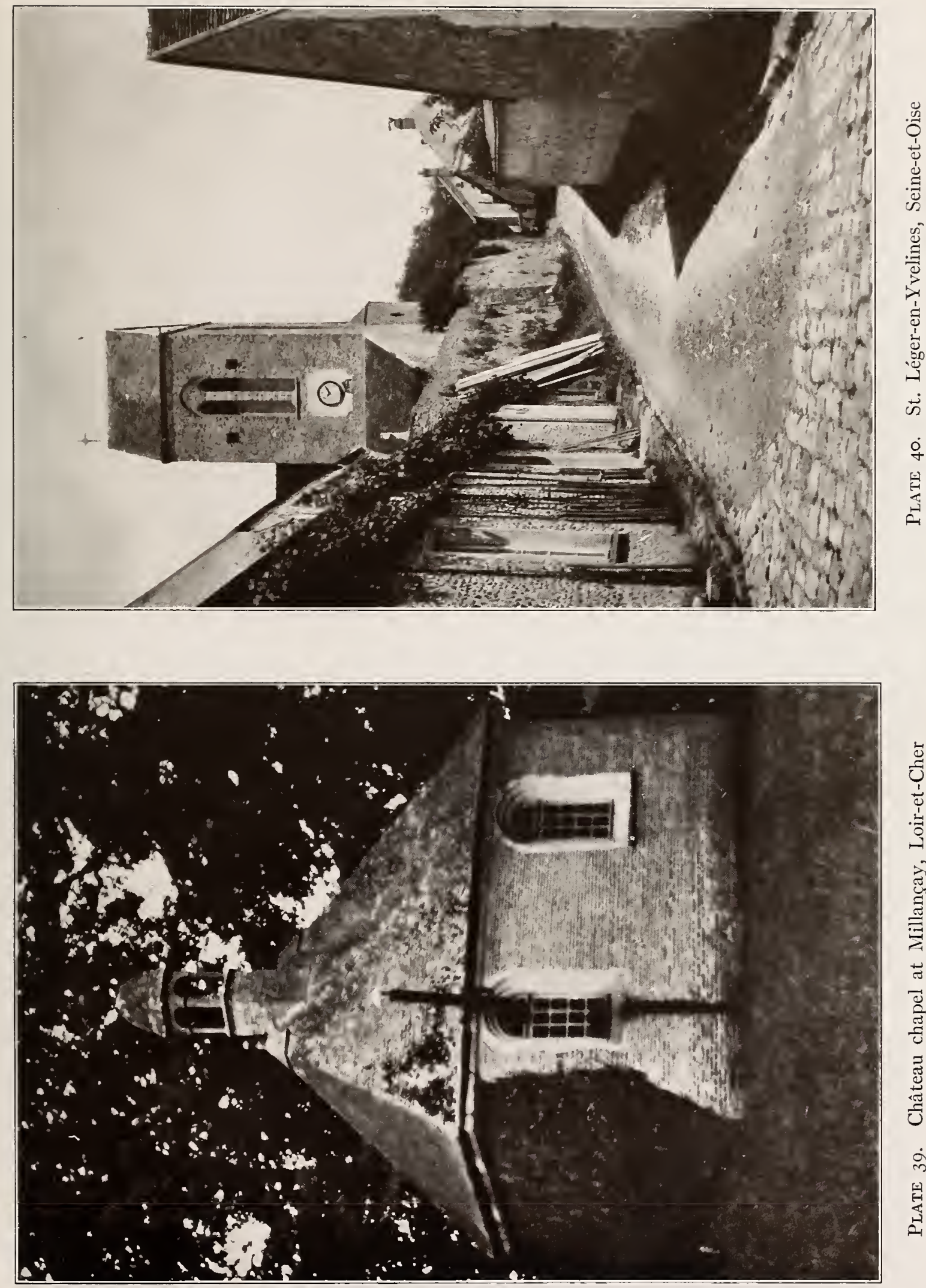

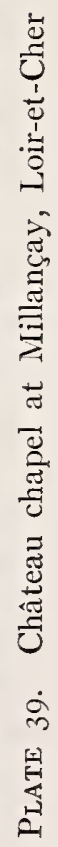





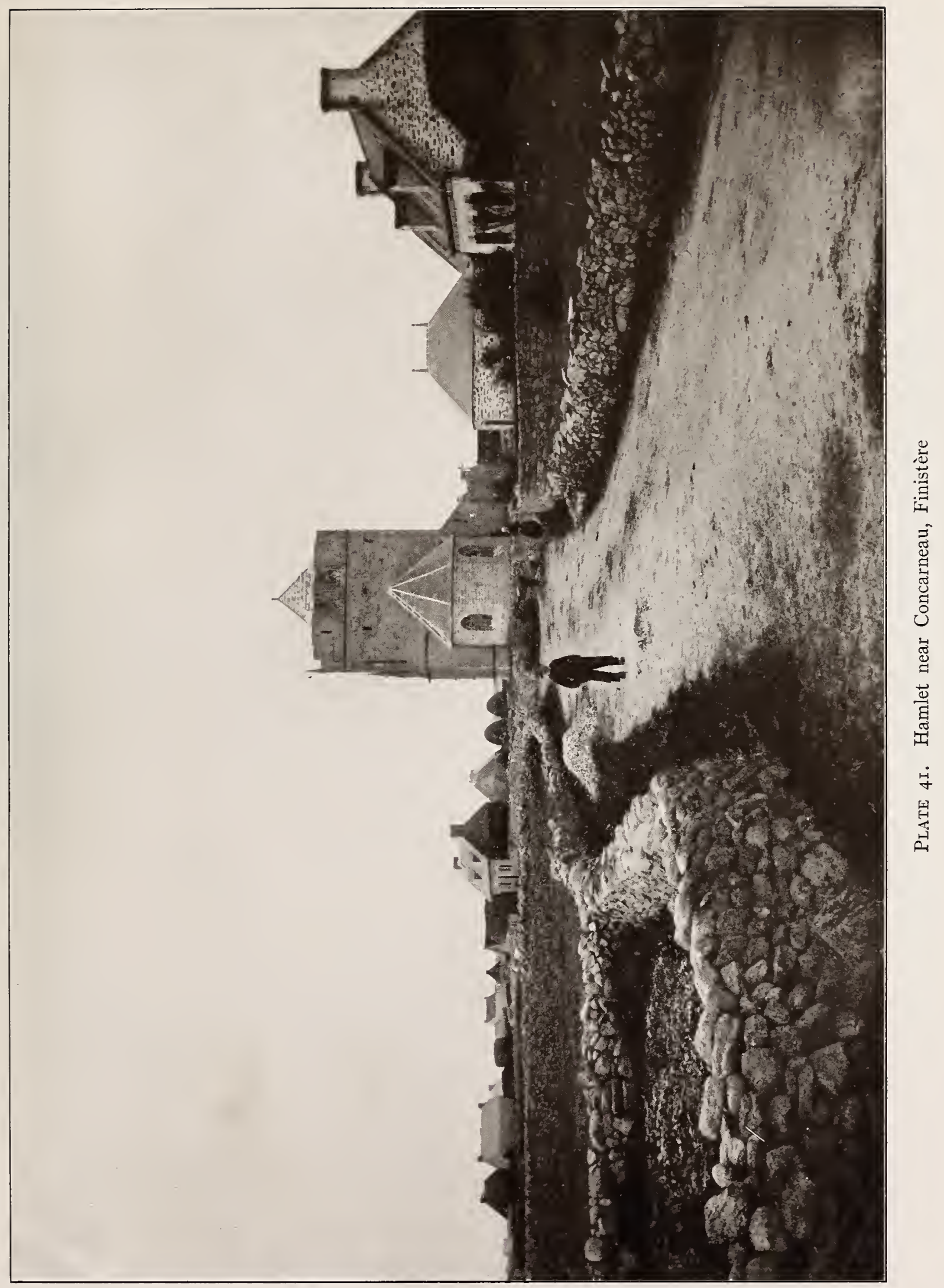




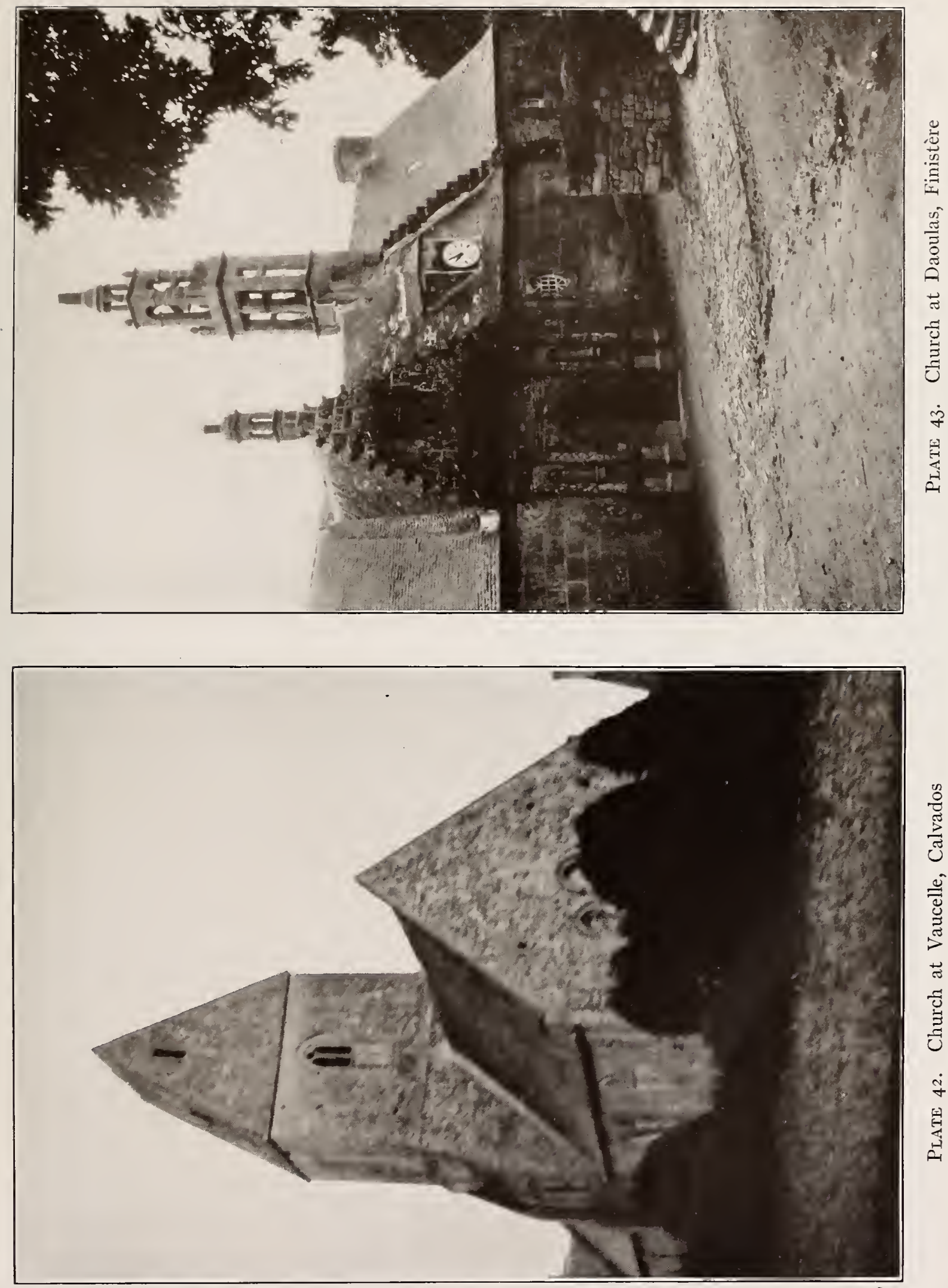



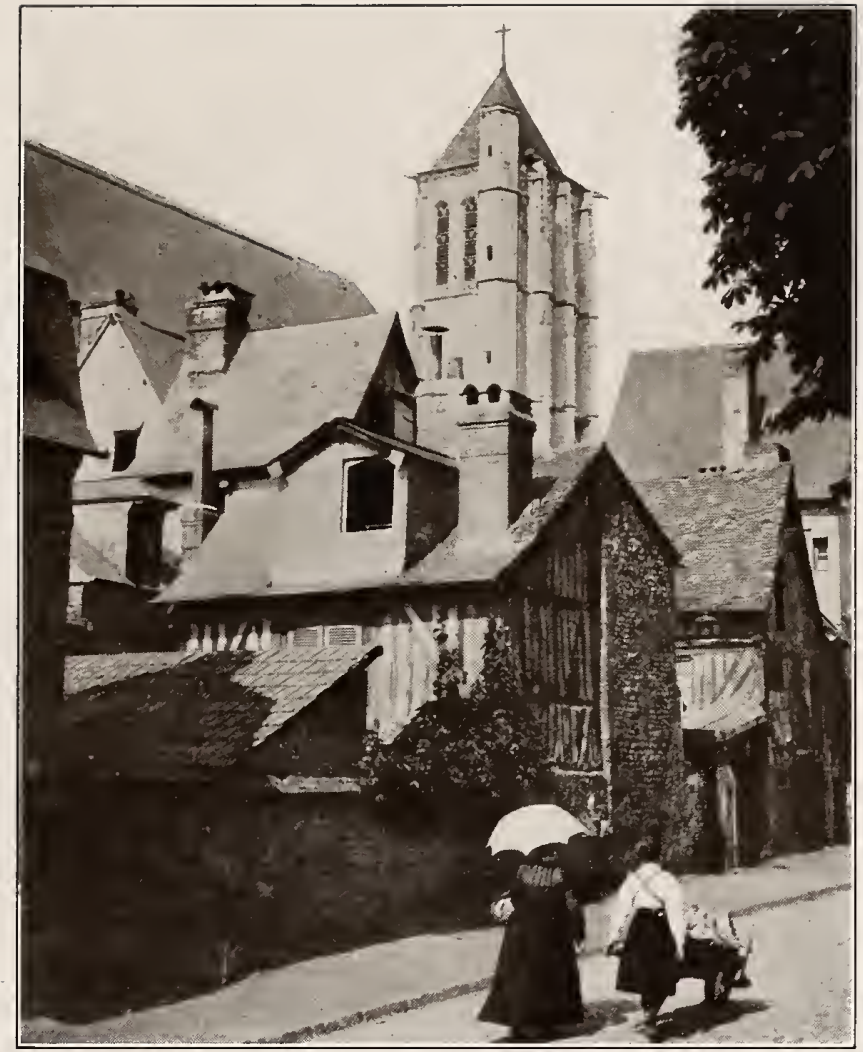

Plate 44. Pont Audemer, Eure

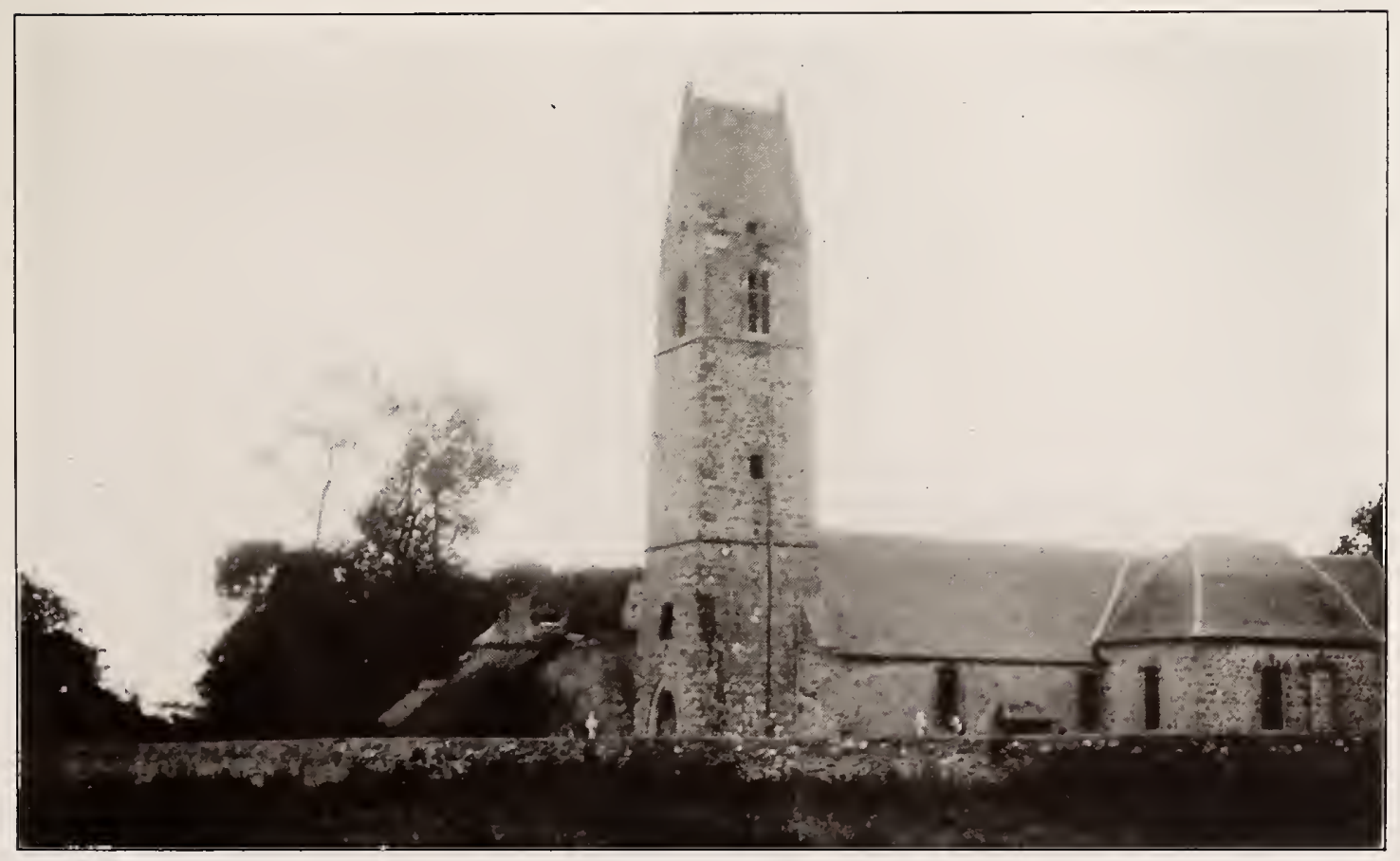

Plate 45. Chapel at Château Gratot, near Coutances, Manche 


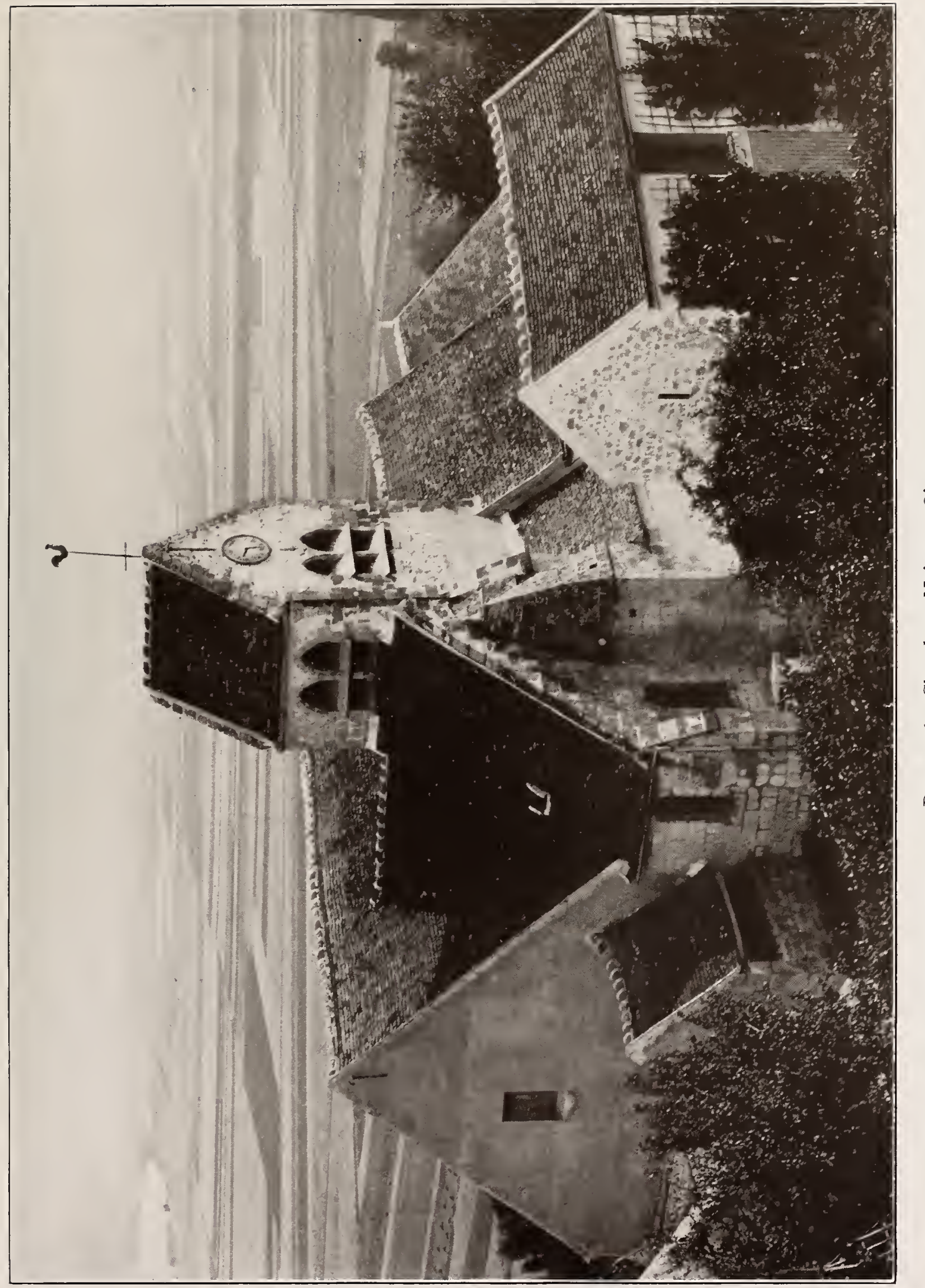





\section{T OW N H O US E}

THE buildings included under this title are chiefly those of the smaller towns, although one or two houses included were found in cities, sometimes incongruously jammed between more pretentious and modern structures.

The roof is considered a most important part of the design, as in the country, giving to the small old town the broken silhouette so usual in France, a picturesque medley of gabled, hipped, and mansard roofs, cut with dormers, crowned with finials, and broken with multitudinous chimney-pots. In many of the old towns the streets are narrow and cobbled, meandering up the natural slopes and often ending in picturesque courts and "cul-de-sacs." In the old half-timbered towns these narrow streets, lined with the ancient stucco and wood houses, are fascinating in color, their grays and yellows set off with bright flowers in window-pots. But they are either difficult to photograph or much of the effect depends on the whole pleasantly jumbled mass and few of the individual houses present in themselves enough value to include.

The lower or street floor, almost invariably flush with the cobbles of the street, is usually given over to a shop or more often a café, and the floor above to the quarters of the patron and his family. The interiors, save for the refreshing coolness and bright bebottled cupboards, present little of interest. The chief attempt at architectural interest occurs in the carved dormers, turrets, corbels, in finials and in some instances in the elaborated carving of the timber of the whole facade. The majority of the half-timbered buildings are Gothic, the detail having a quaintness and piquancy seldom found in ecclesiastical work. Rarely is there any attempt whatsoever at symmetry; in fact, there seems to have been a complete abhorrence of it, resulting in much picturesqueness. Some of the interesting features of the subjects included are as follows:

Plate 47 is a stone shop in Brittany with the chief interest centred in an elaborately carved stone dormer; Plate 48 an early Gothic gable end with wide wall surfaces, heavily accented belt courses, and unusual double ogival curves over the windows; Plate 53 shows an interesting contrast between the narrow richly carved half-timbered house and the more simple and generous corner house adjacent to it. Brick and flint pattern work has been used on the gable end of the little house on Plate 59, the contrast between the salmon color of brick and weathered stone not being too strong in reality.

That it is possible to obtain an excellent effect by simple means, is shown by Plate 60, where plain wall surface, broken only in heavy courses of corbels, has 


\section{TOWN HOUSES}

been so proportioned that there is much charm in the effect. Note that in the building in Plate 62 the overhanging second-story porch is nicely carried on wood brackets, and below, that the openings have Gothic arches. On Plate 63 is an example of a symmetrical design which has been given an informal character by the materials themselves, buttered stone walls and irregular pan-tile roofing. The loggia is an interesting feature, Italian in character, with a beamed ceiling, though it has been unfortunately marred by modern window-sash.

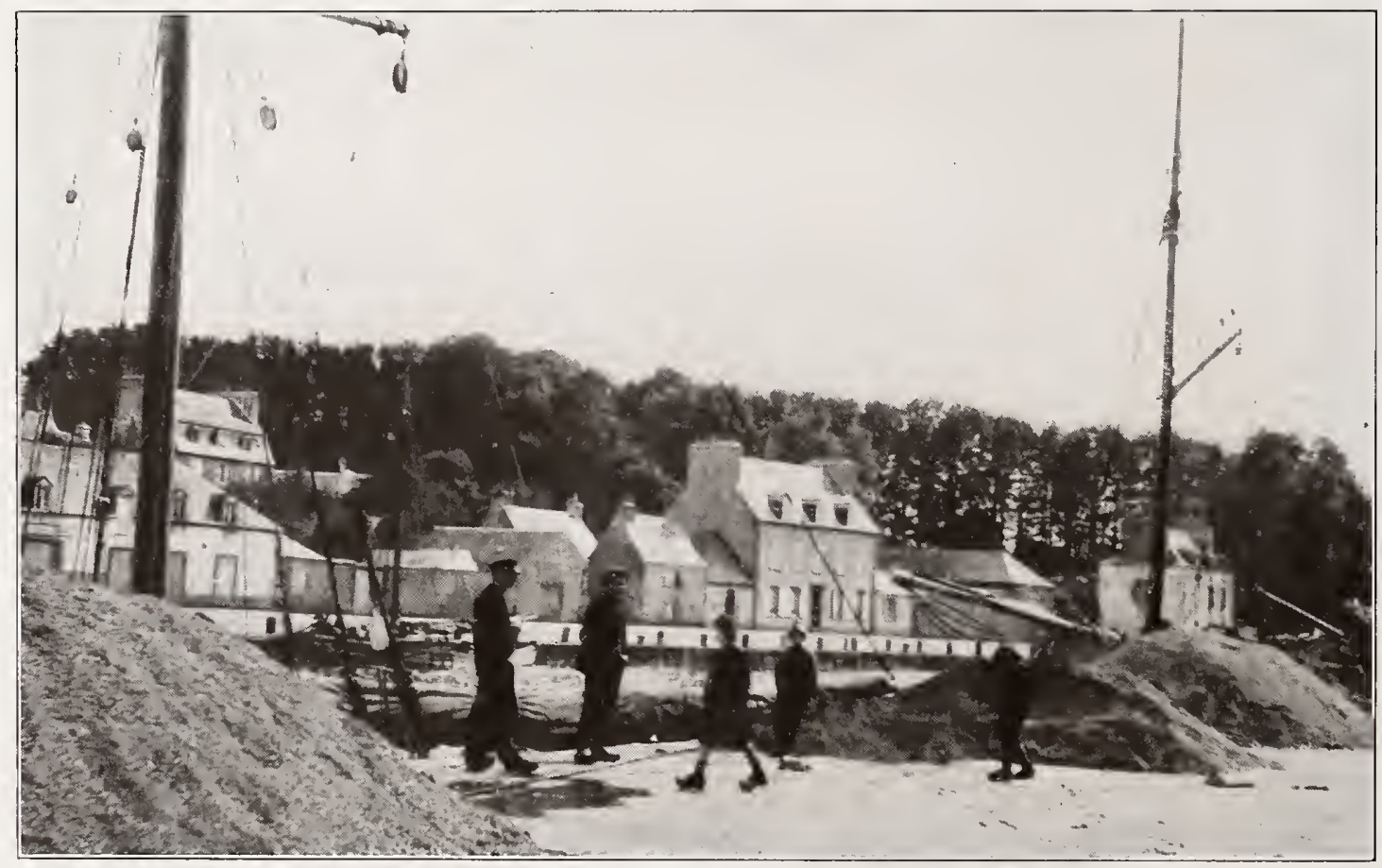




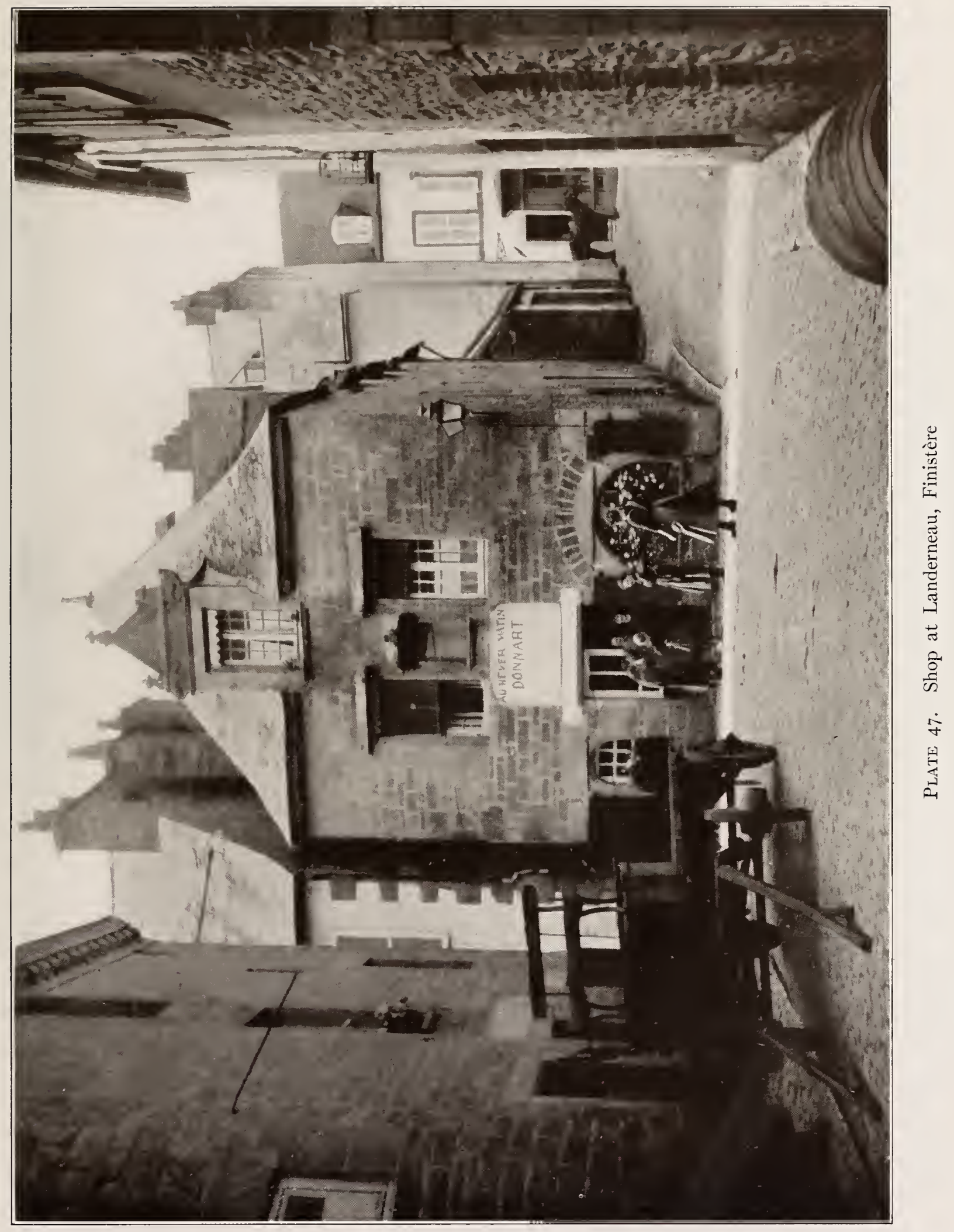





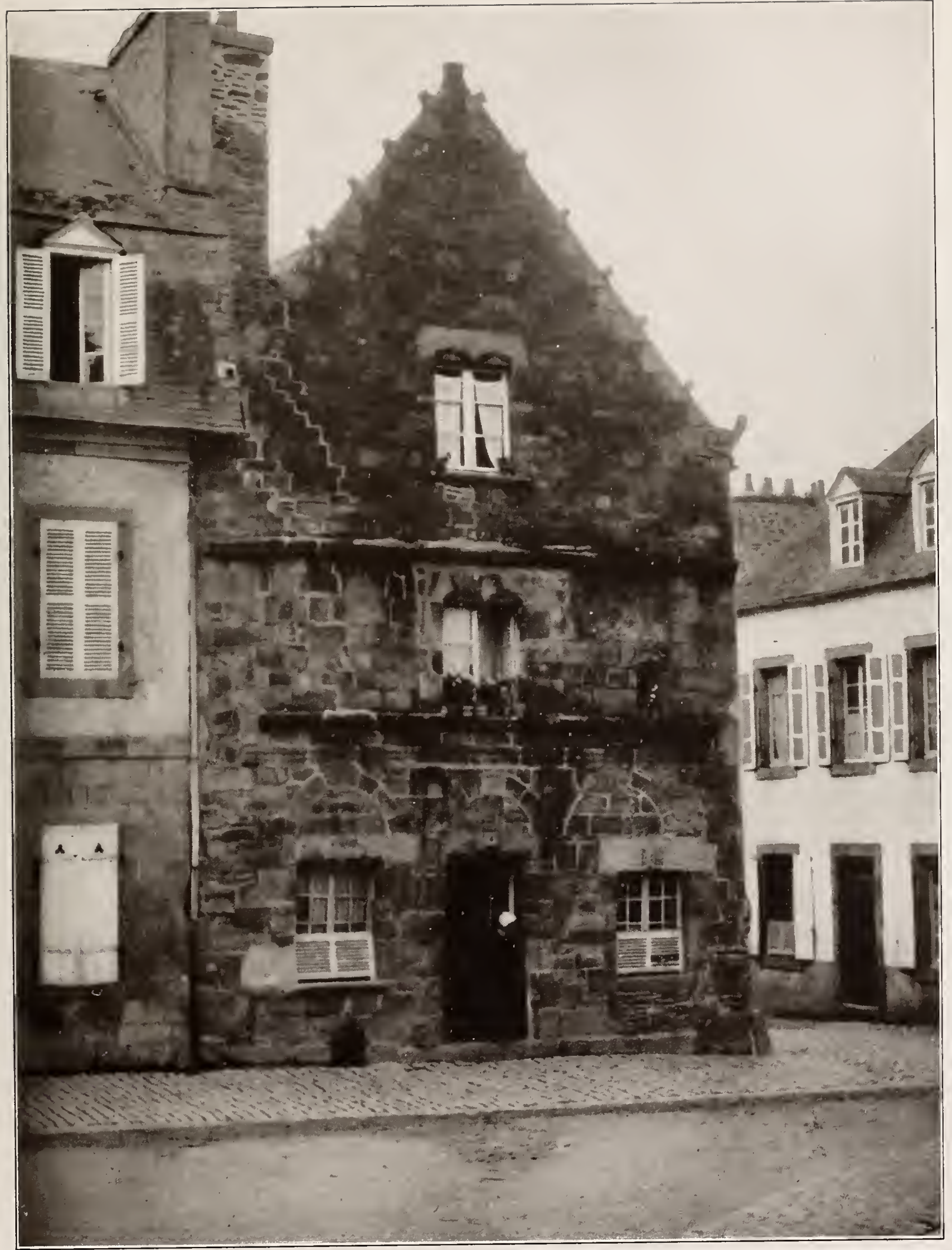

Plate 48. House at Landerneau, Finistère 



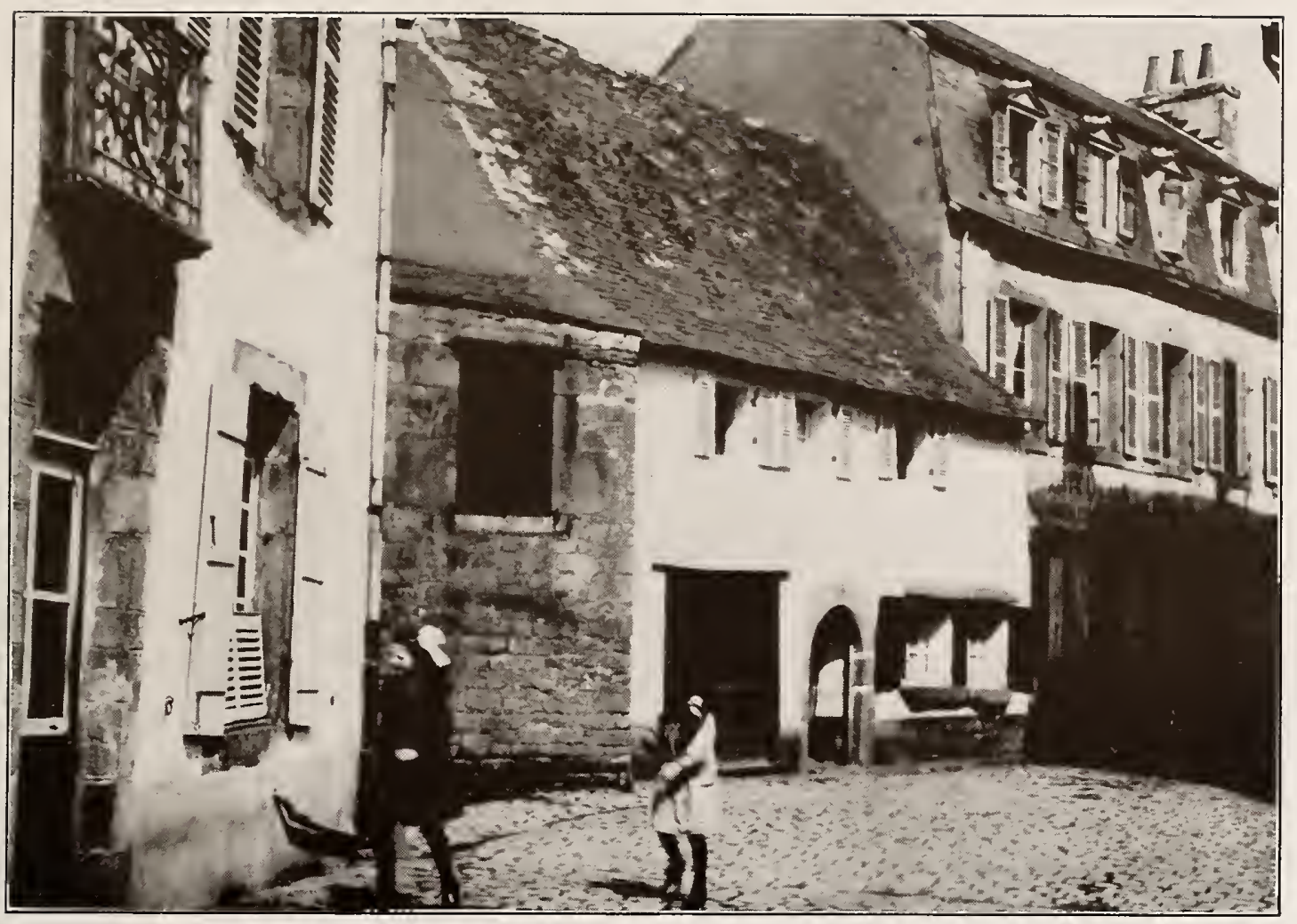

Plate 49. House at Landerneau, Finistère

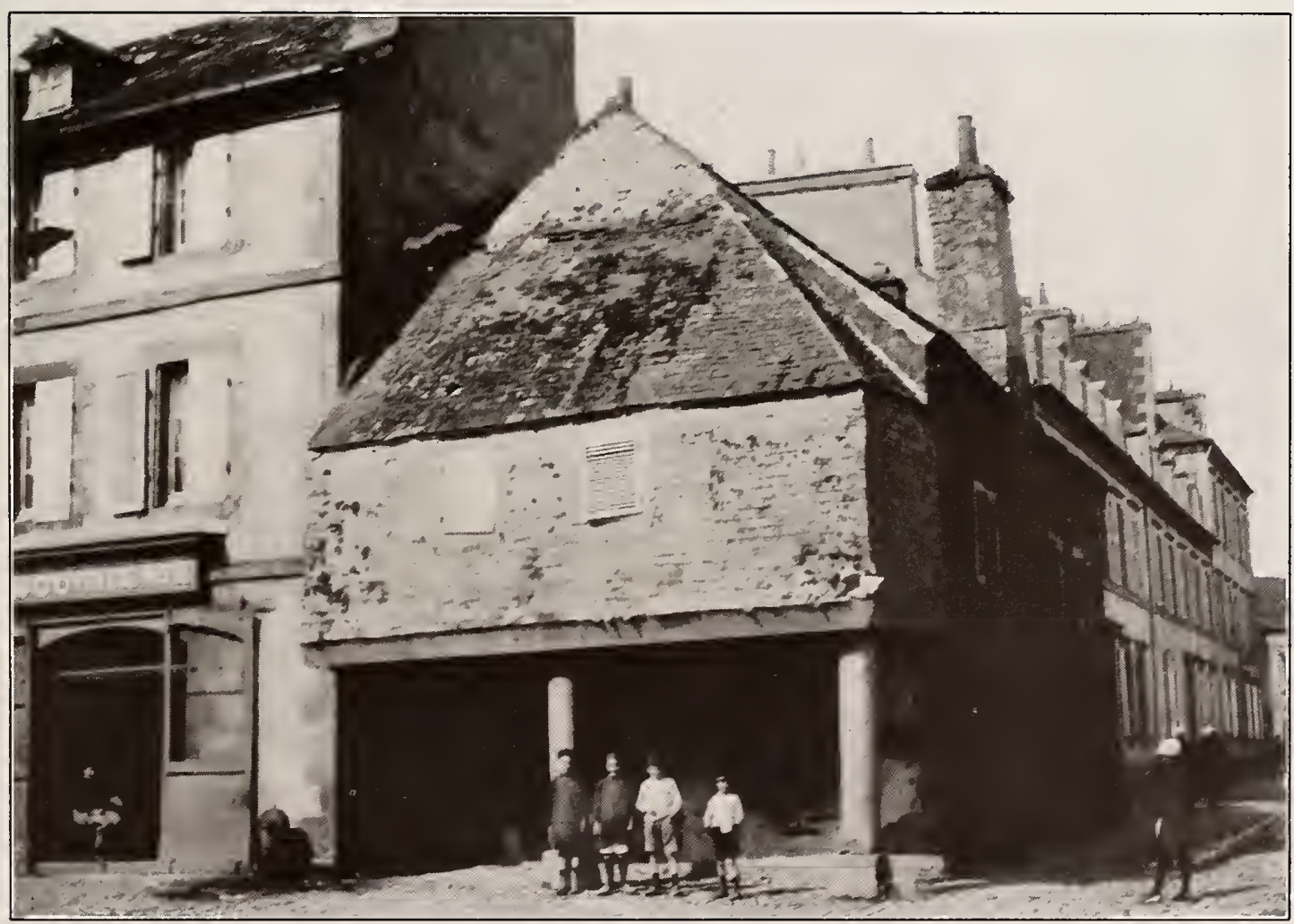

Plate 5o. Hôtel des Trois Piliers, Landerneau, Finistère 



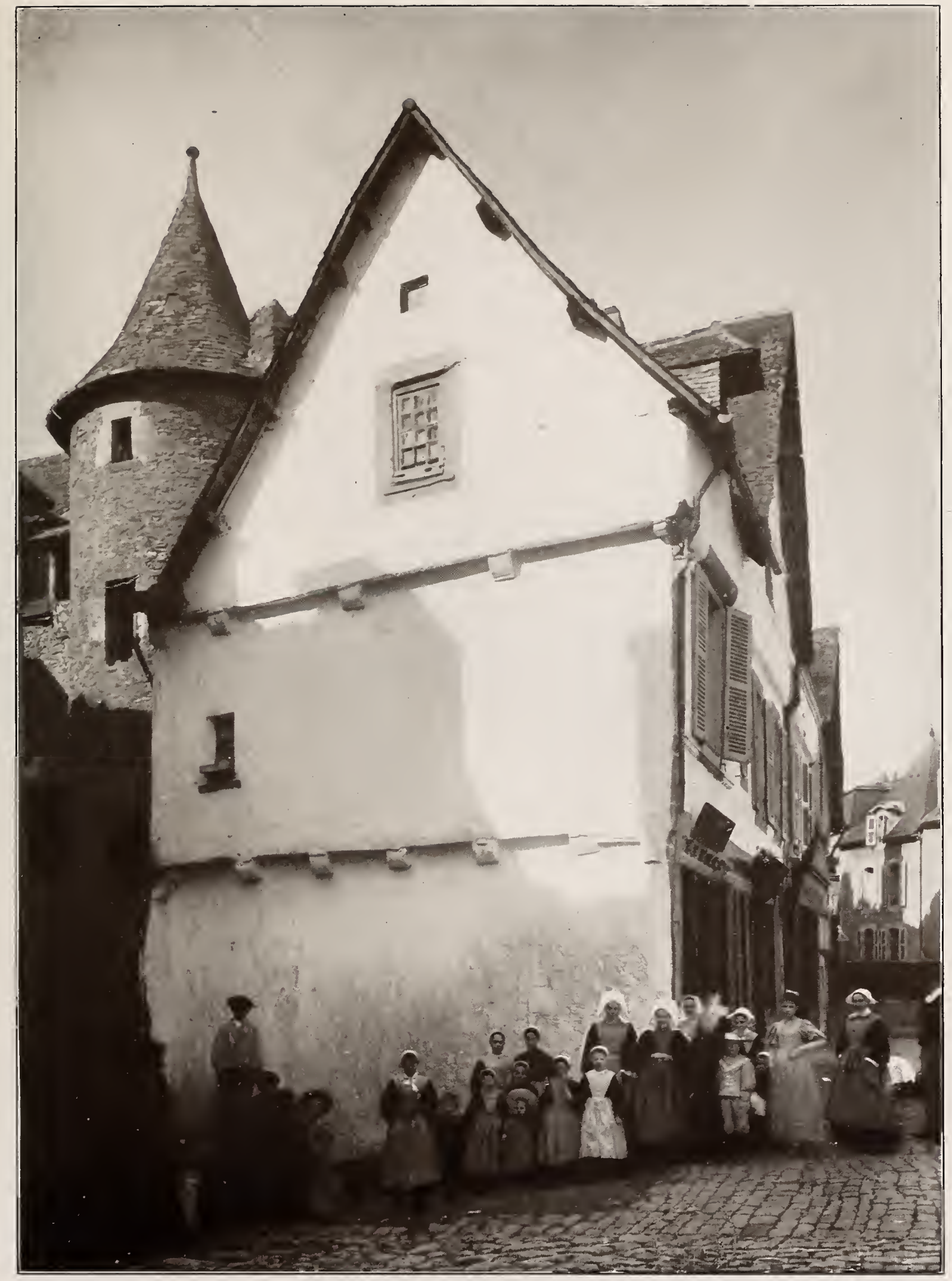

Plate 5I. House at Hennebont, Morbihan 



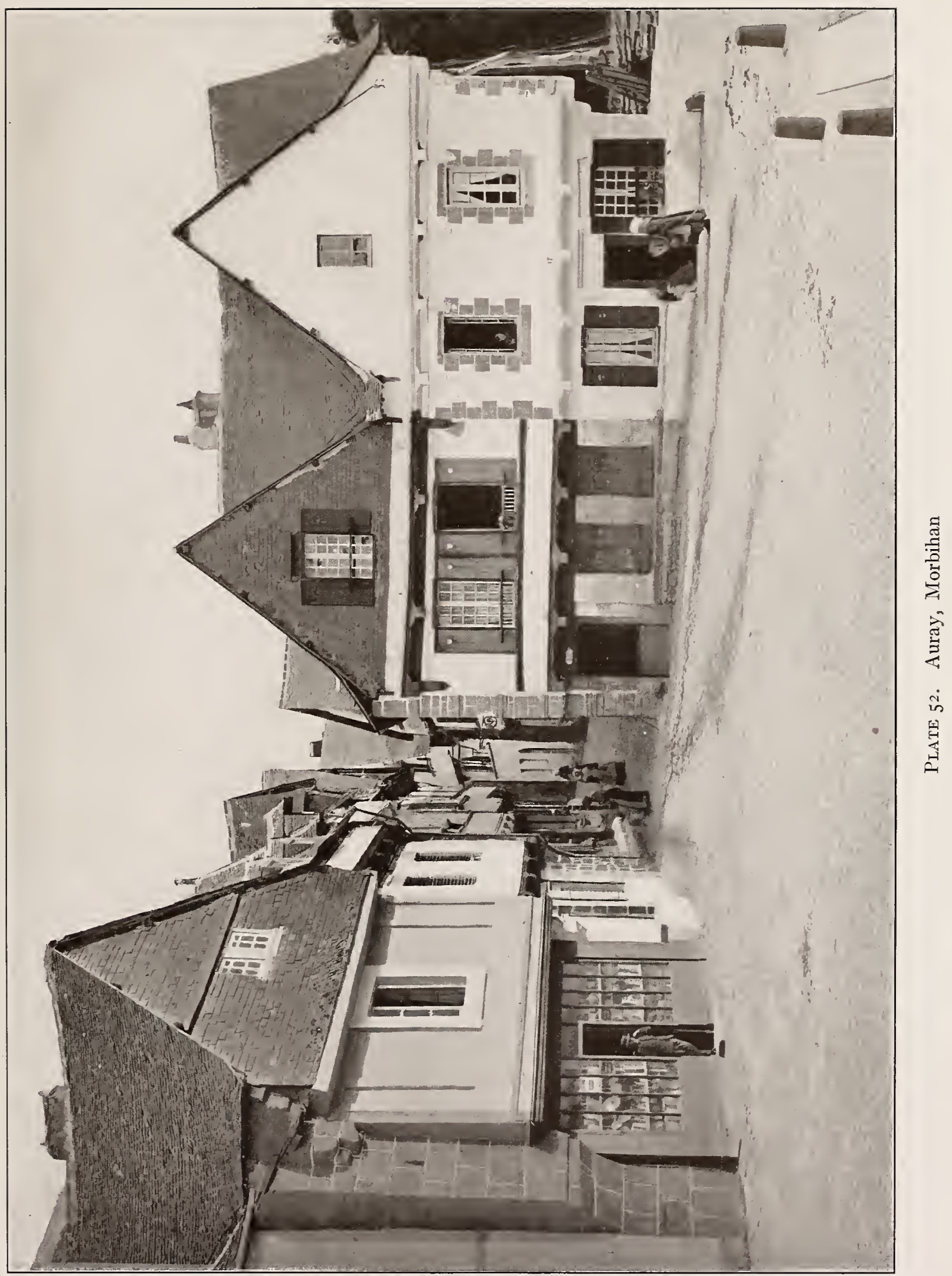





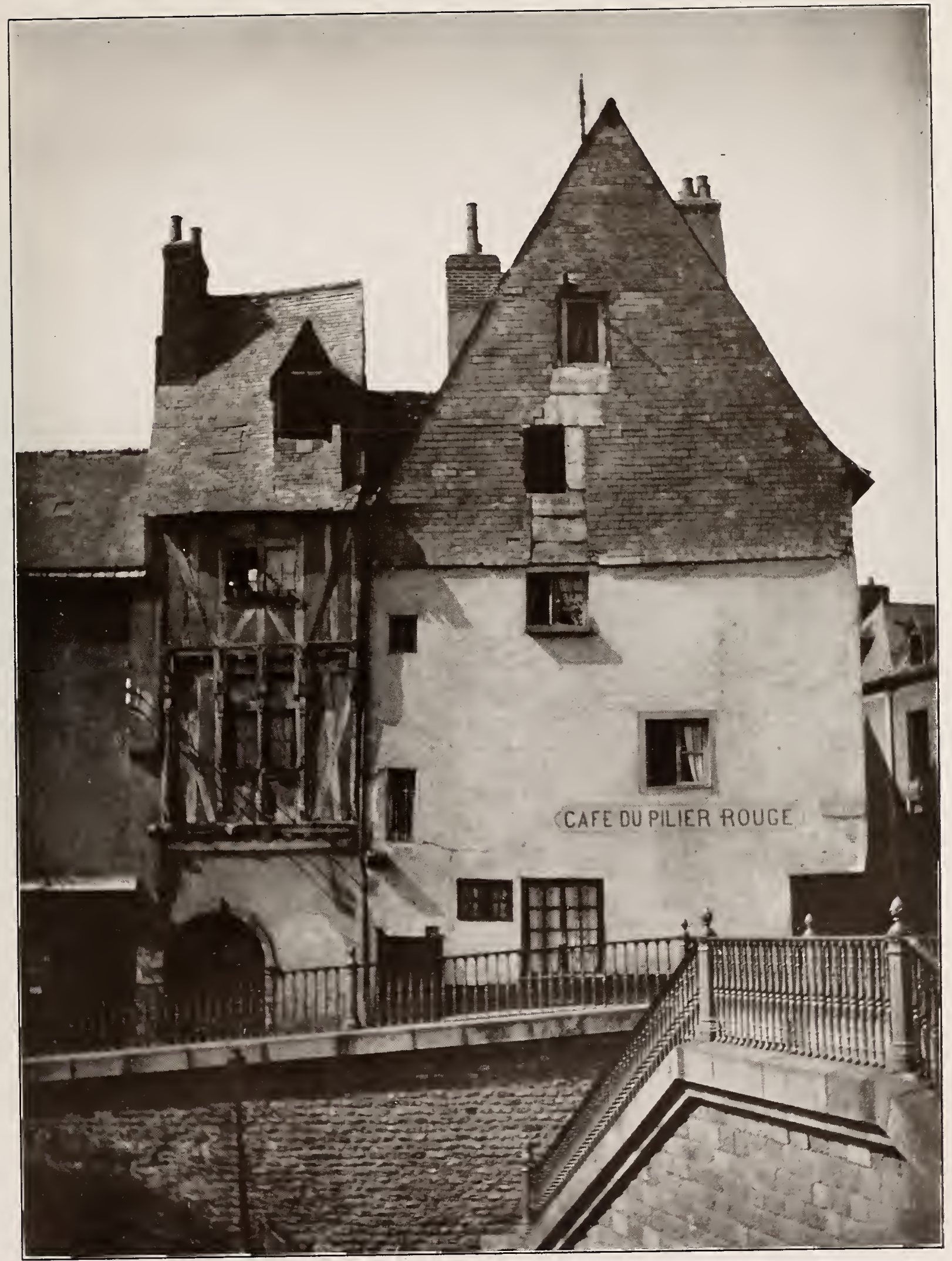

Plate 53. Le Mans, Sarthe 



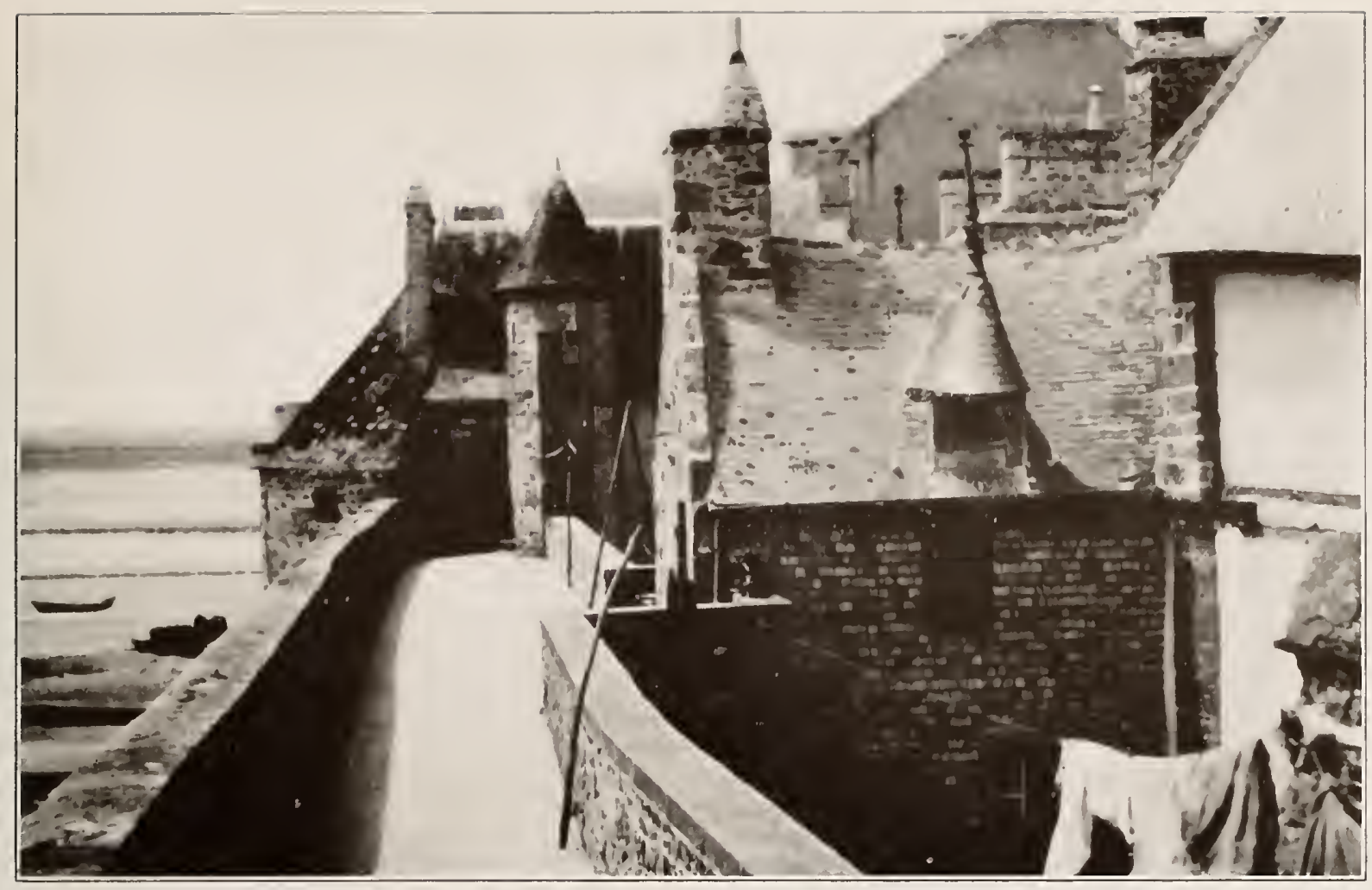

Plate: 54. On the ramparts, Mont St. Michel, Manche

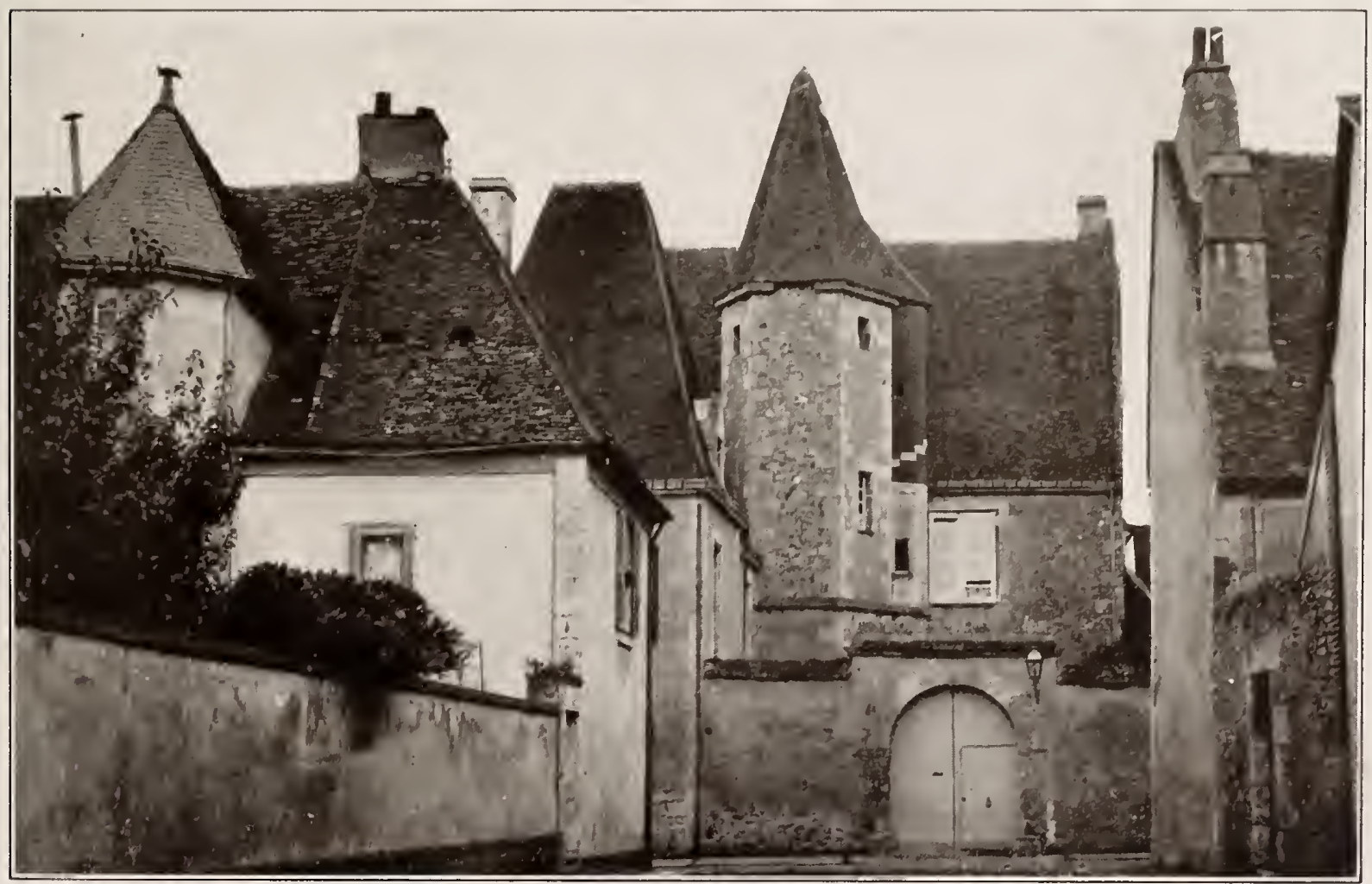

Plate 55. Nogent-le-Rotrou, Eure-et-Loir 



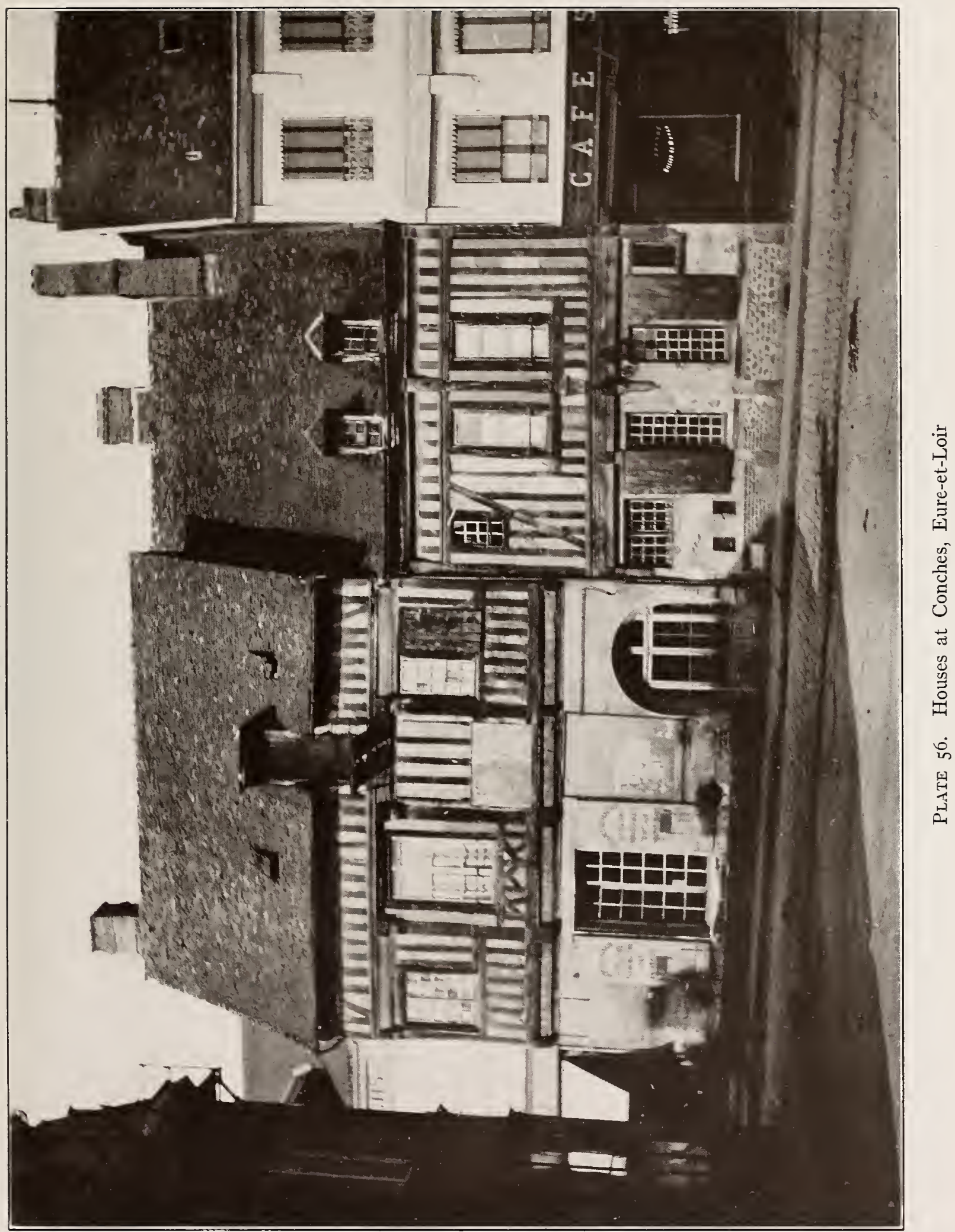





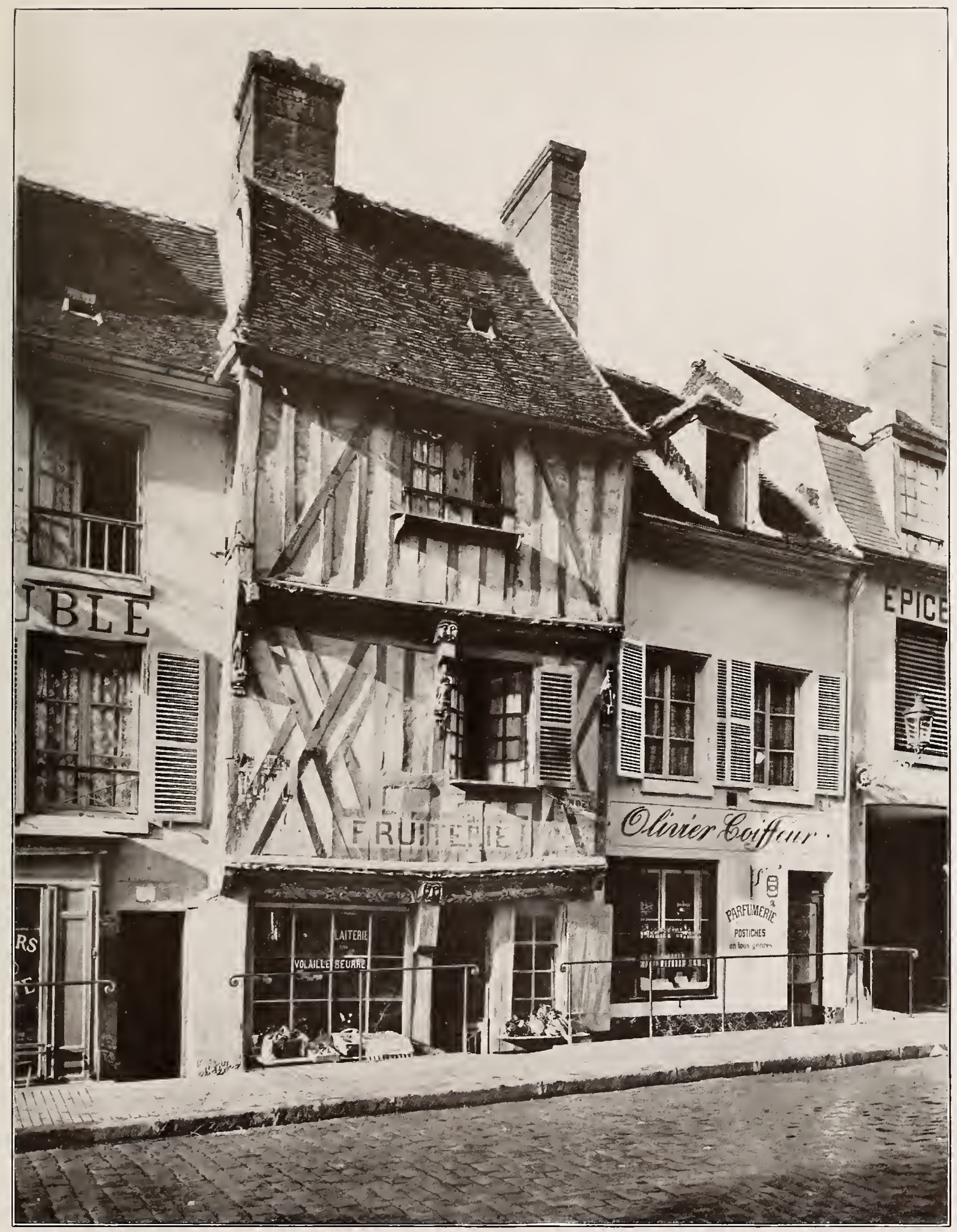

Plate 57. House at Compiègne, Oise 



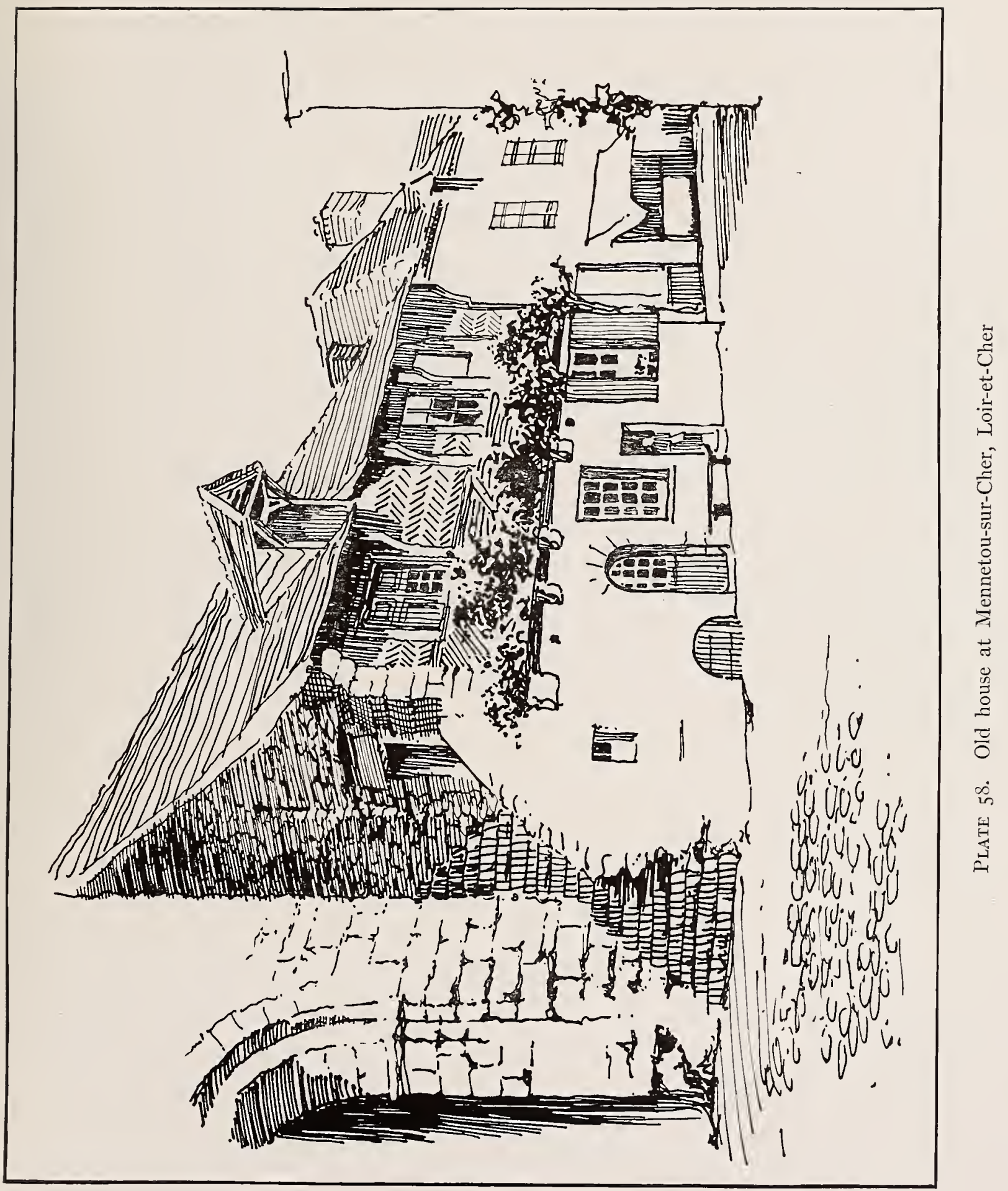





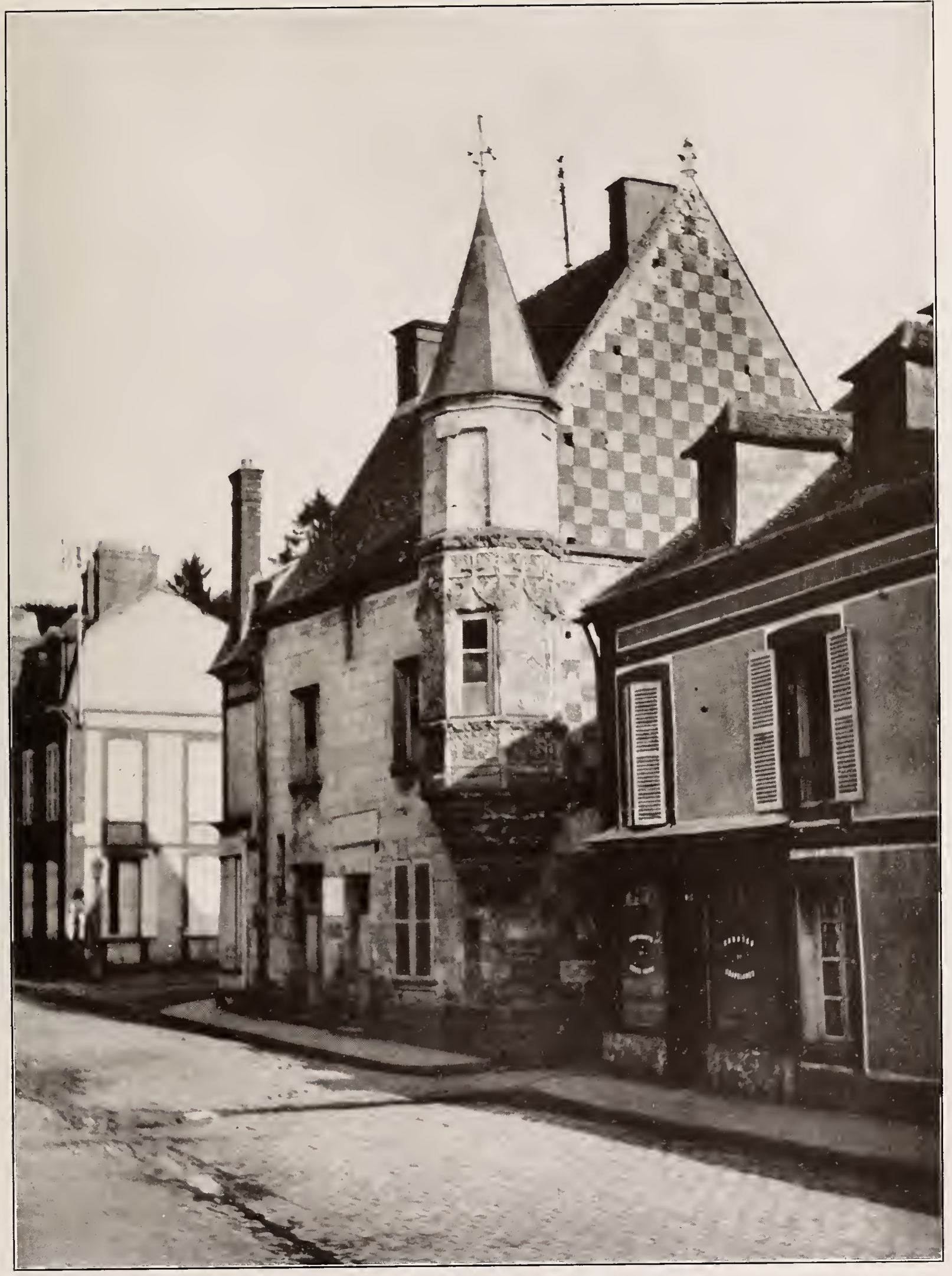

Plate 59. House at Verneuil, Eure 



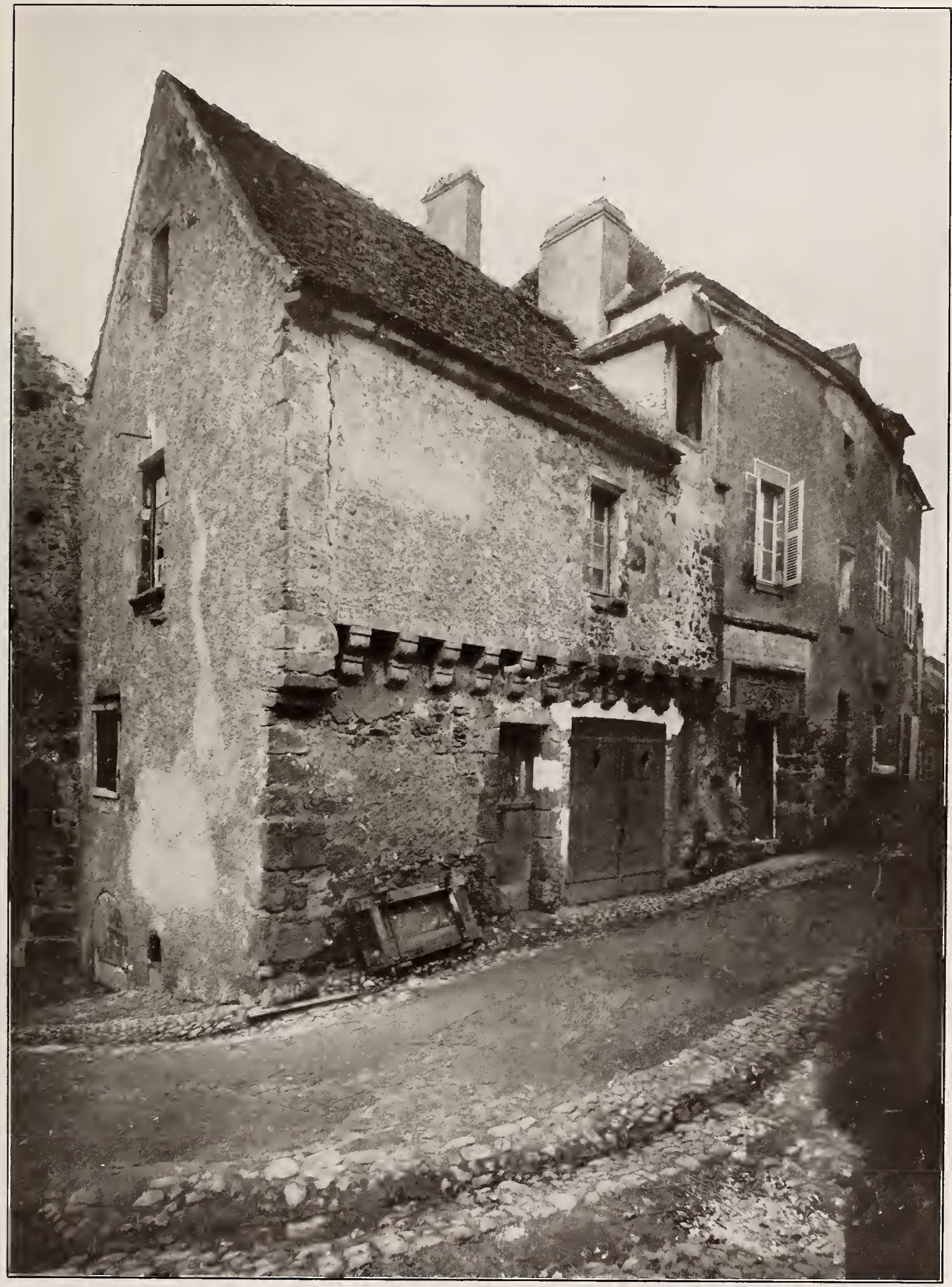

Plate 60. An old town house 



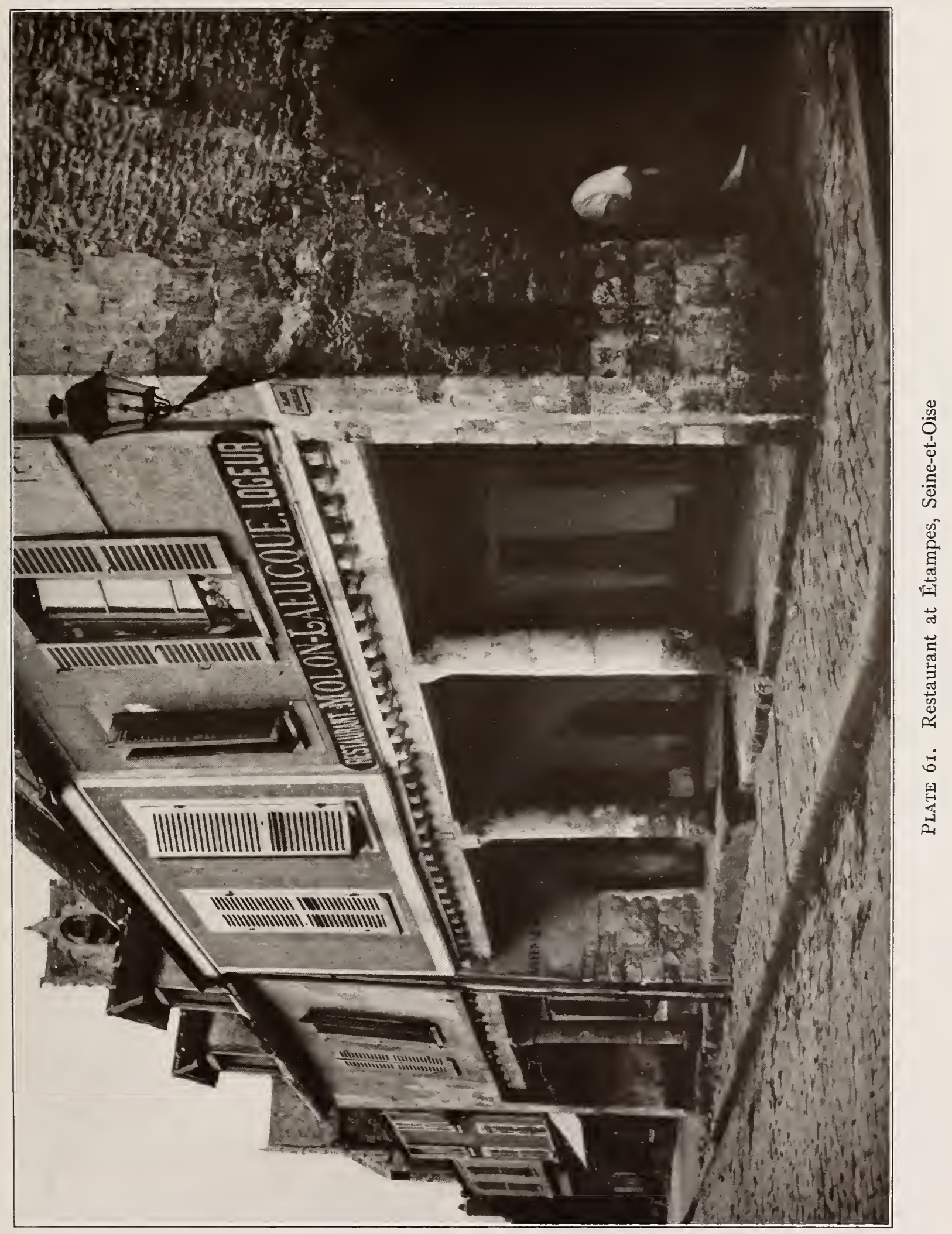





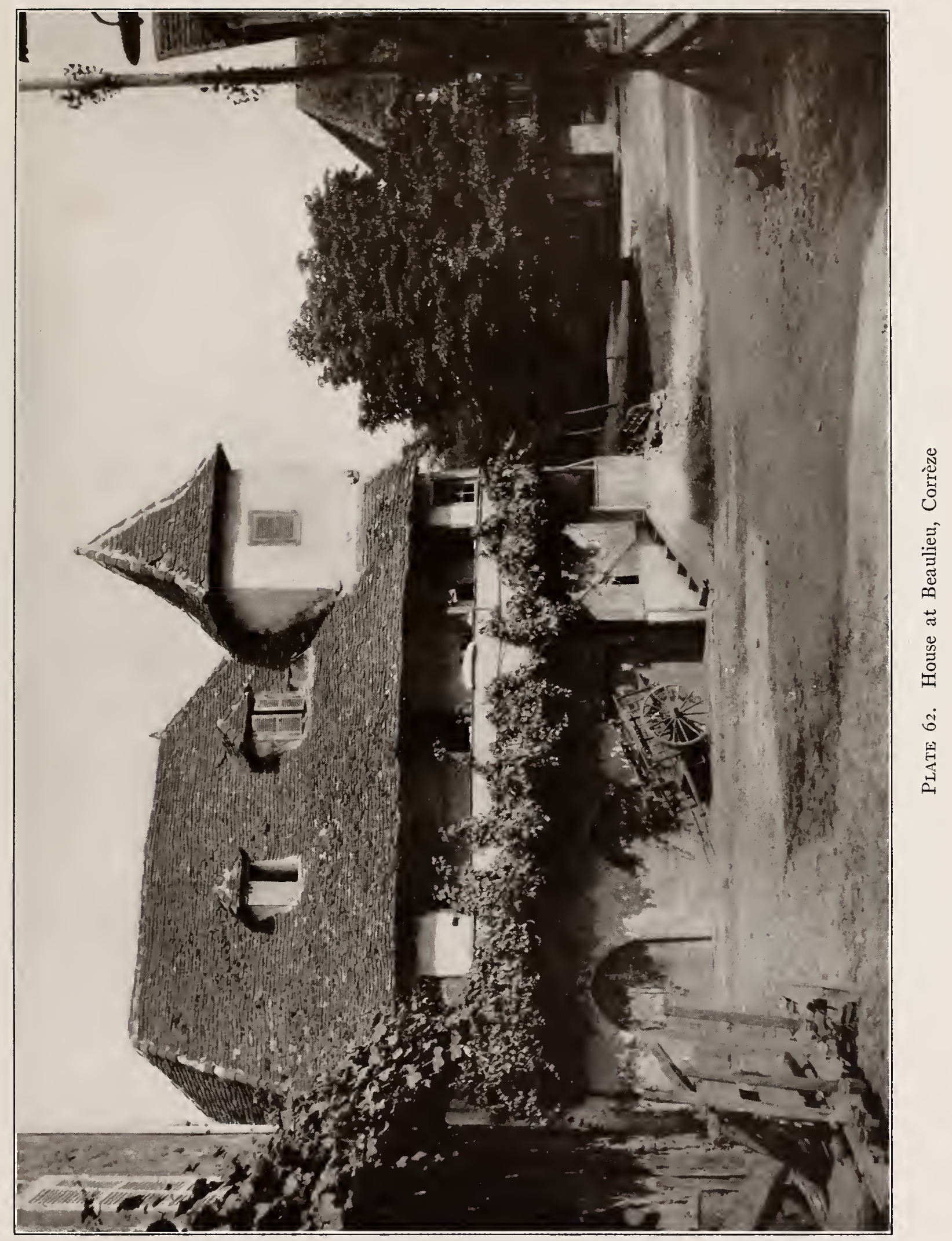





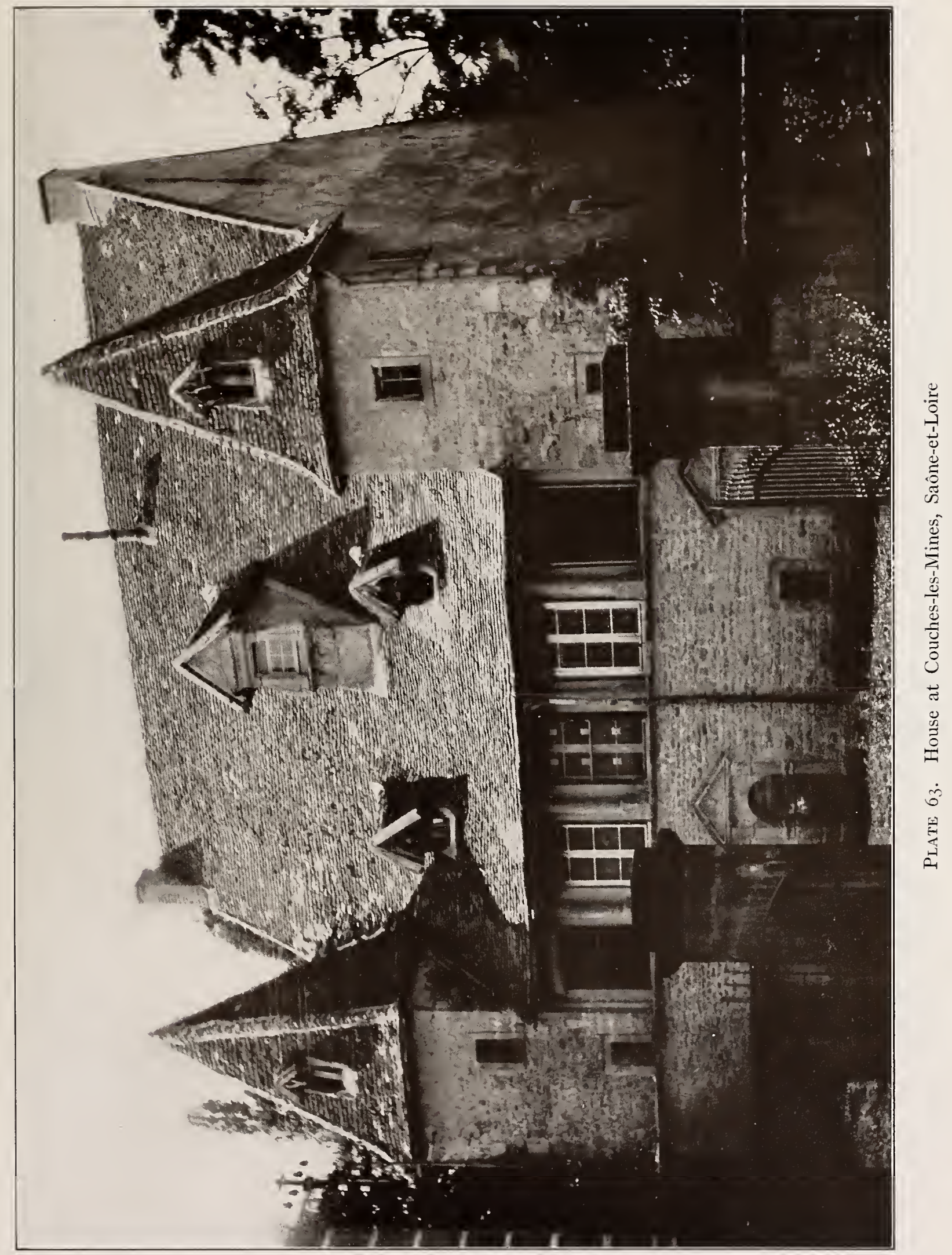





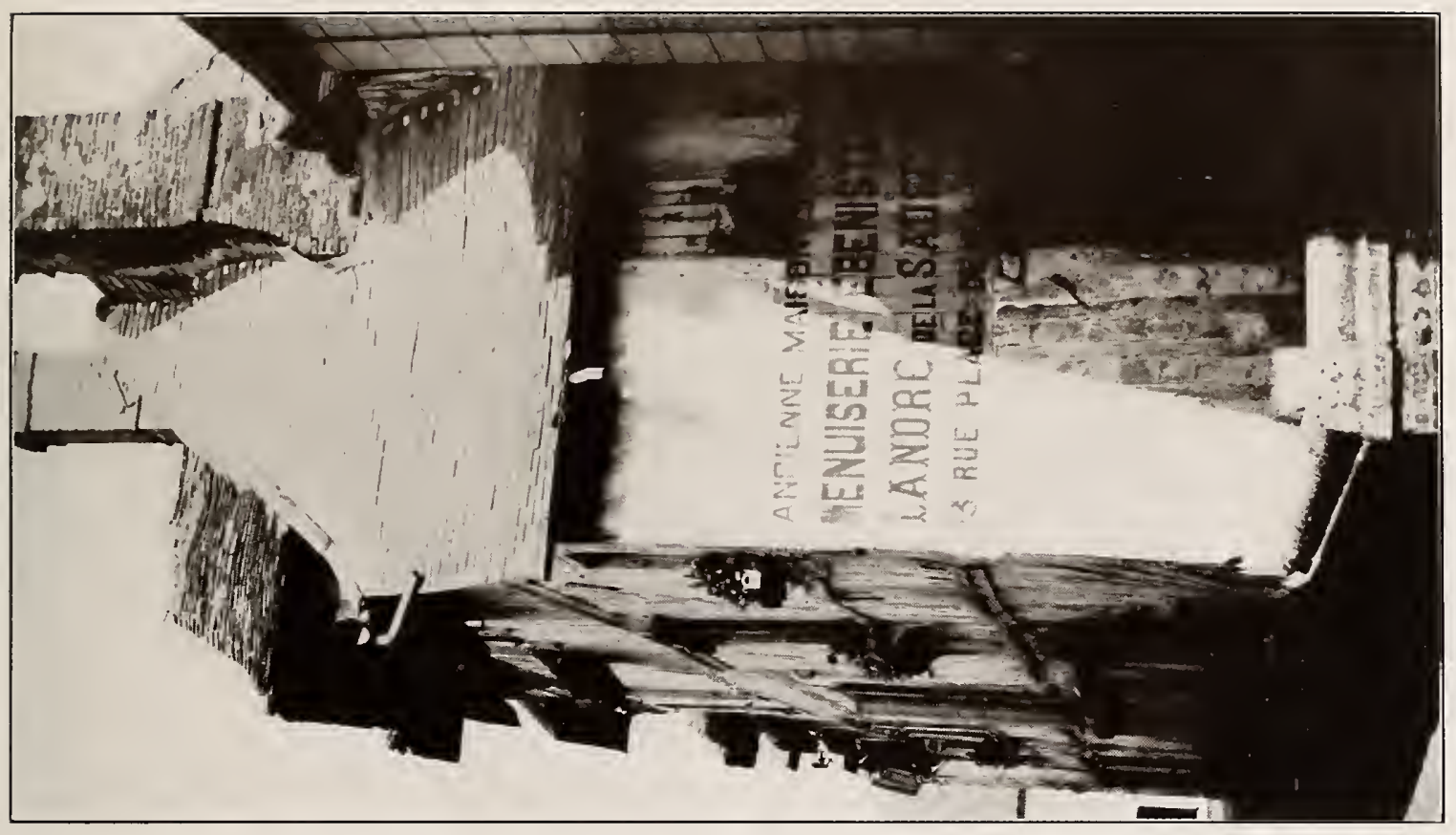

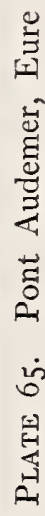

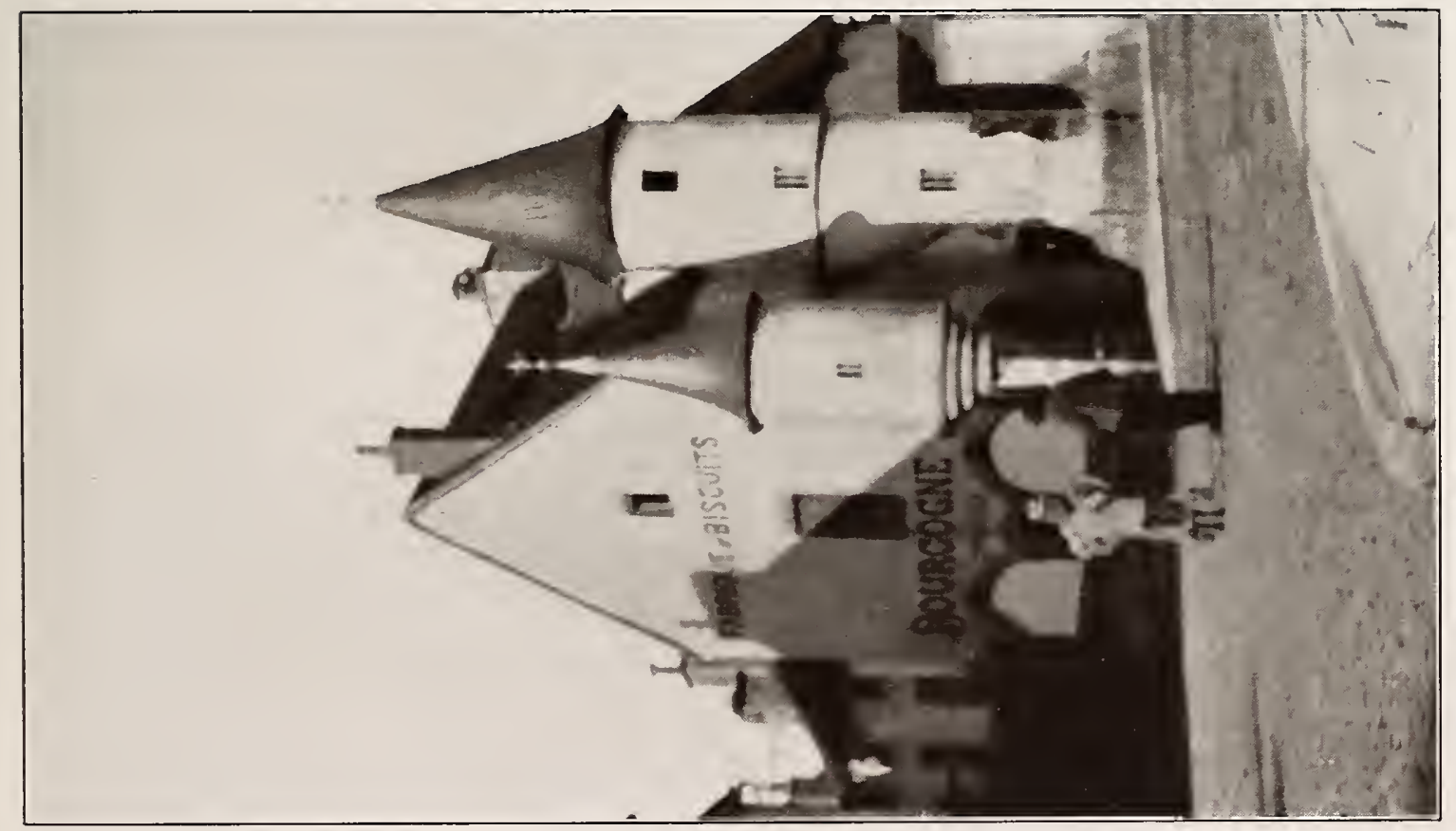

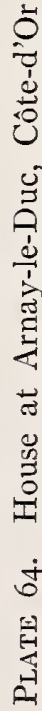




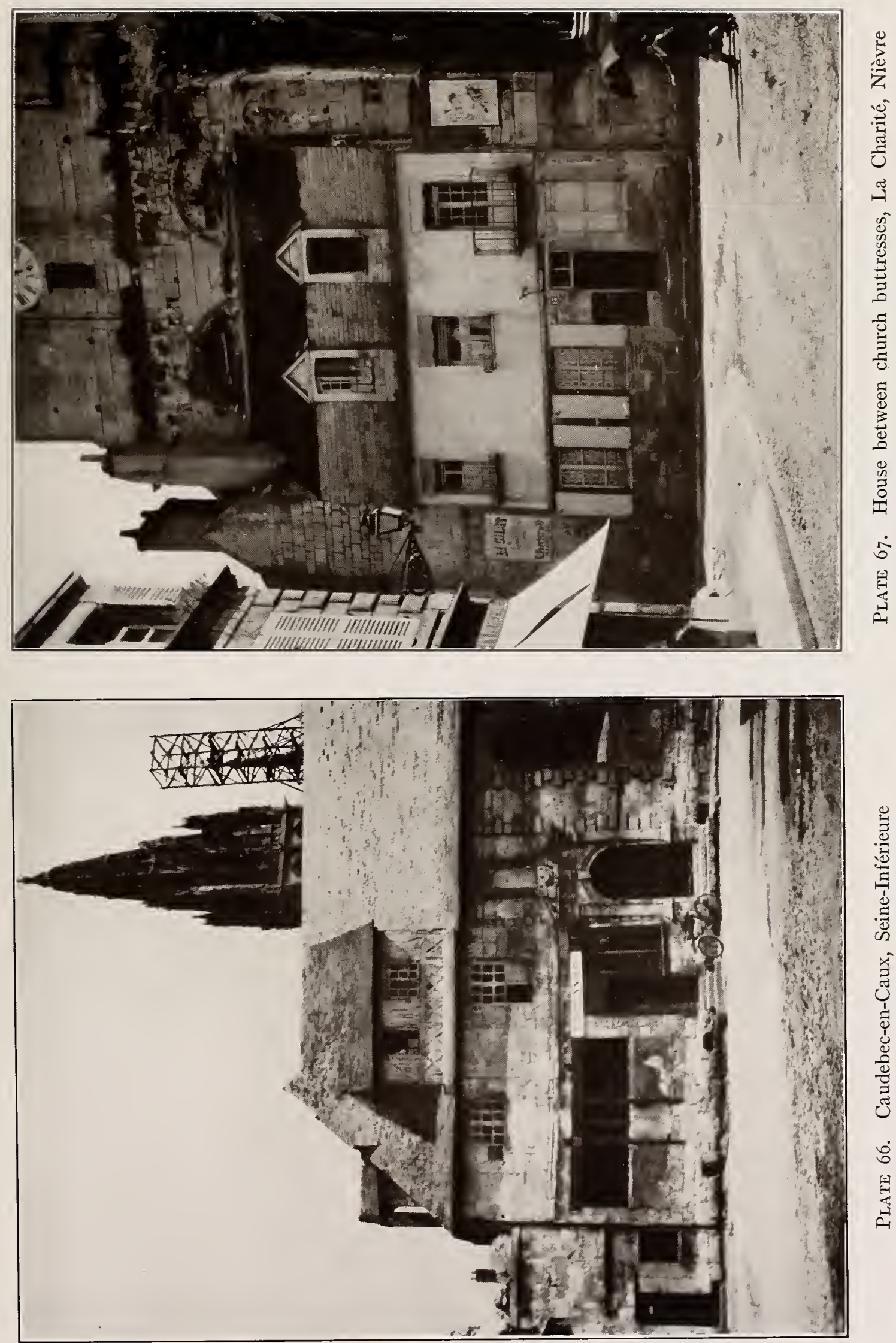

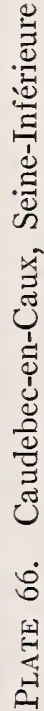




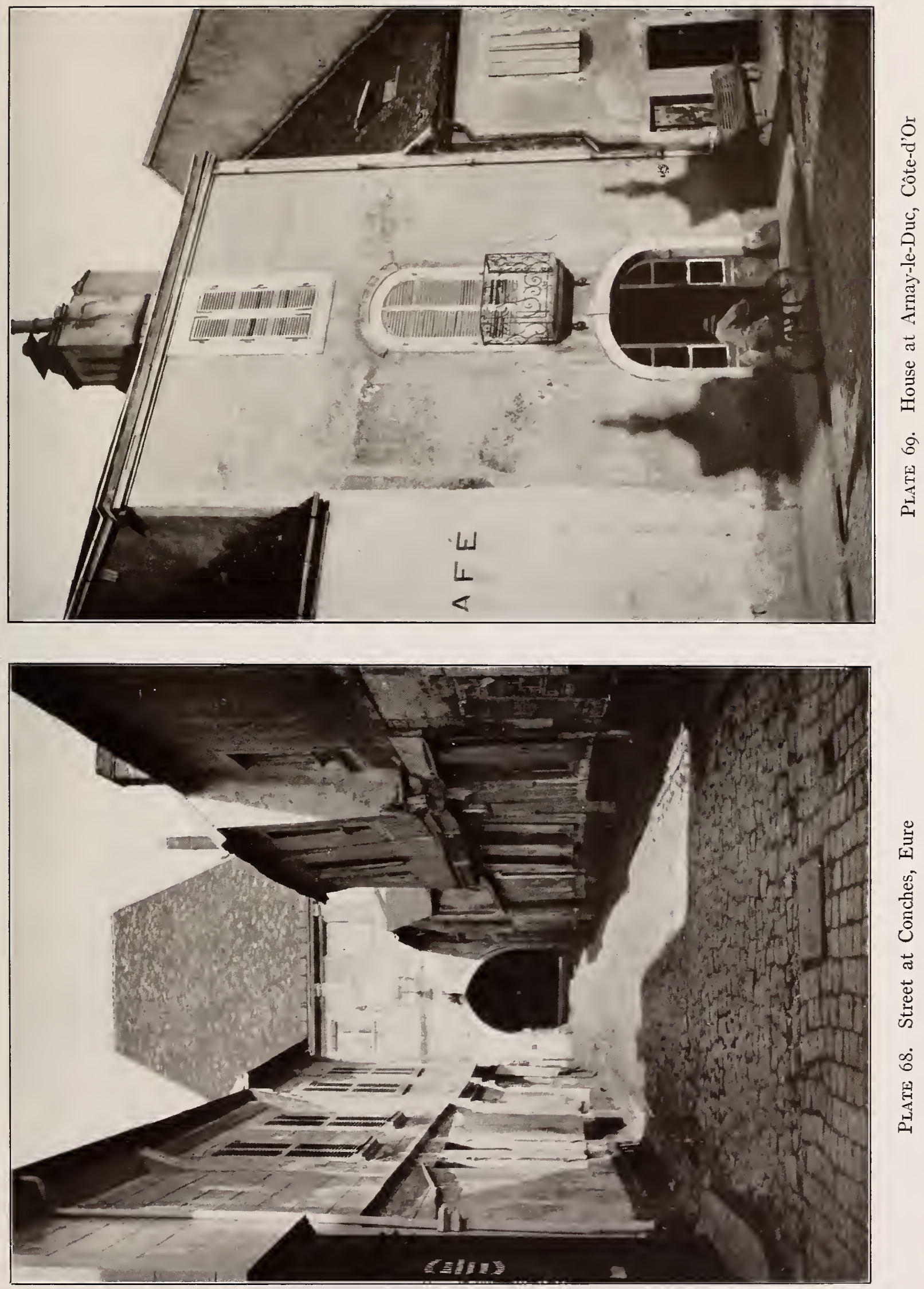



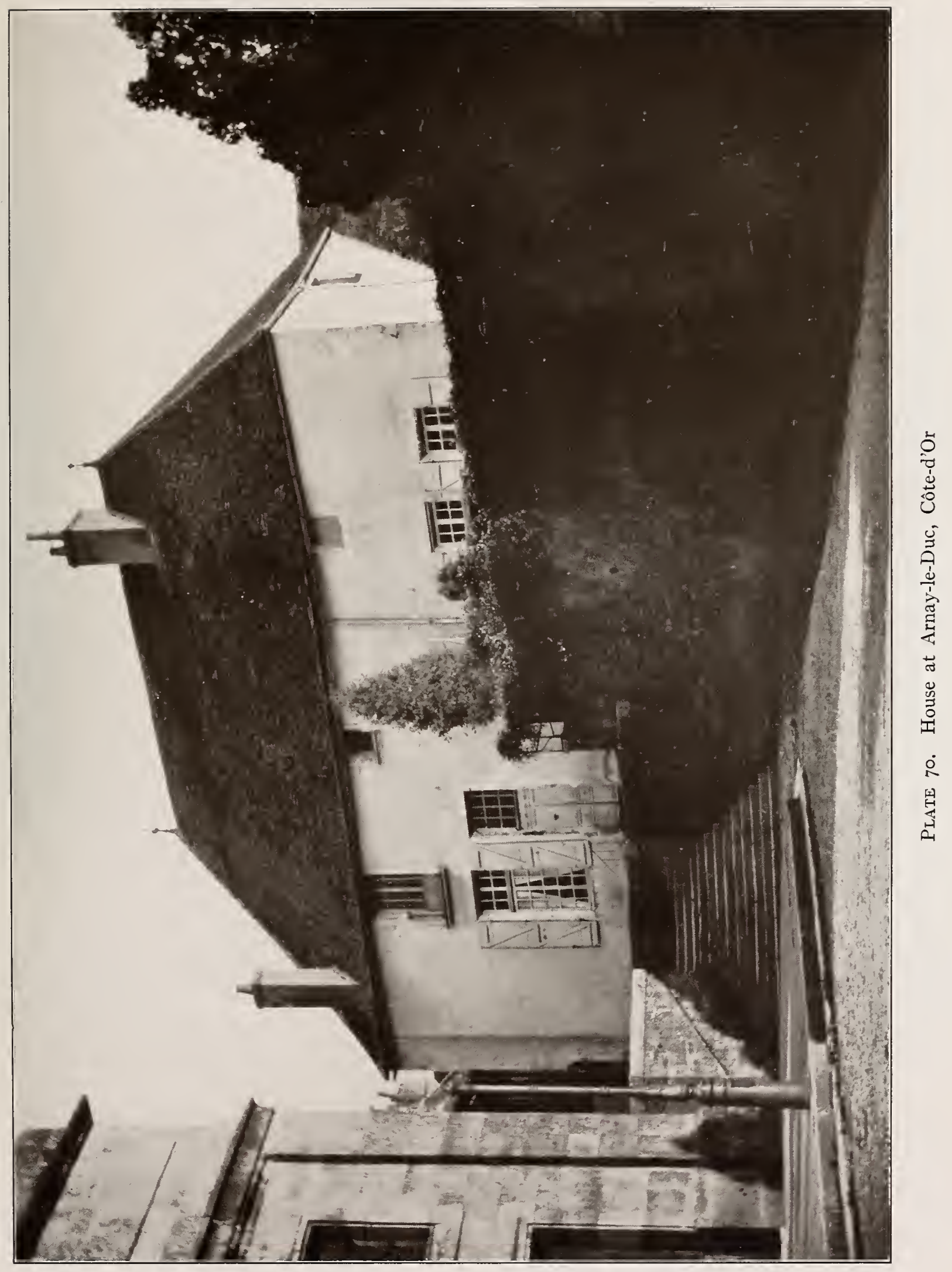





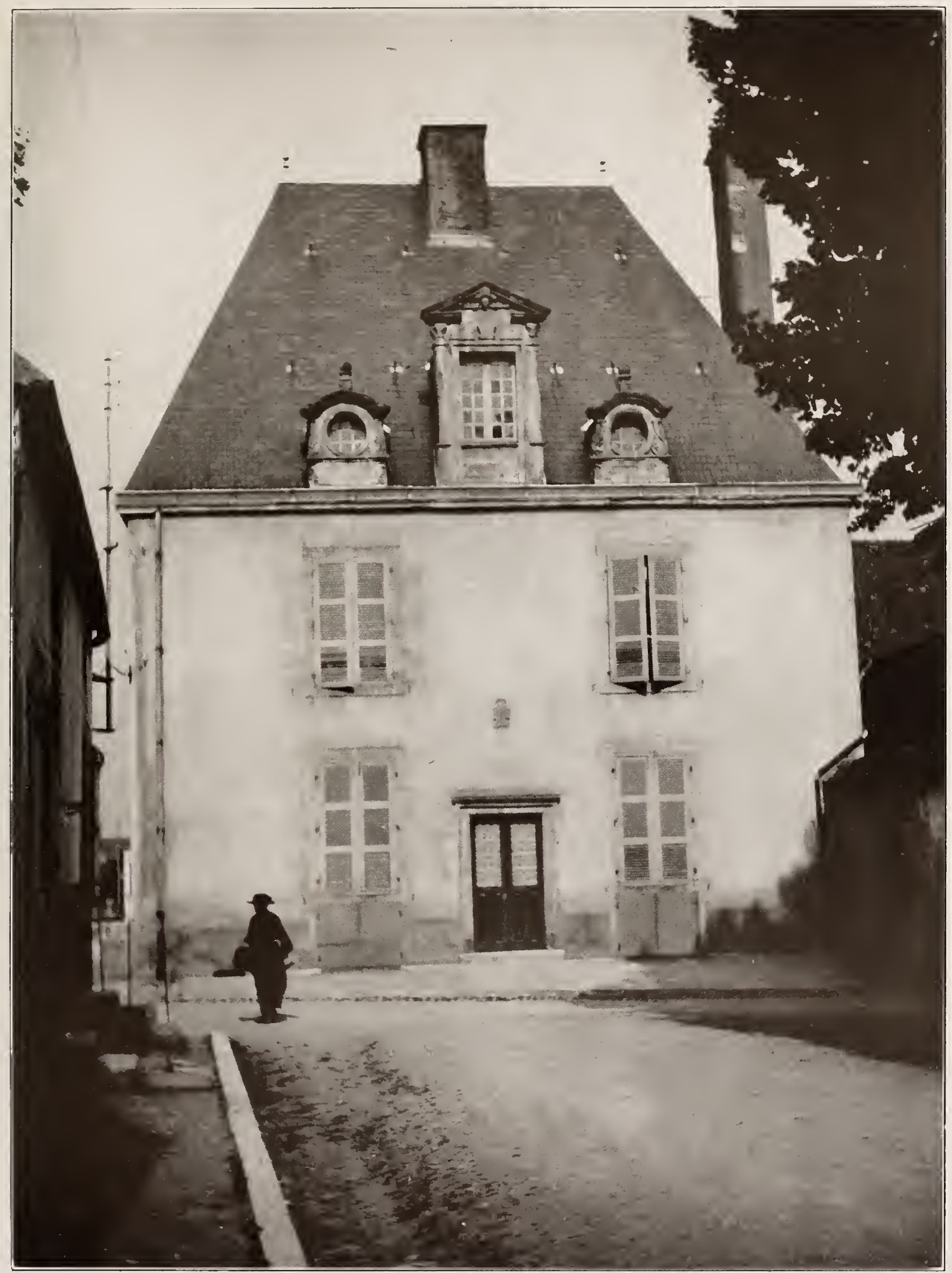

Plate 7r. House at Arnay-le-Duc, Côte-d'Or 



\section{GHÂTEA UX, MA NORS, A N D F A M G R O U P S}

THE buildings illustrated in this chapter are those which through some pretense of elegance or size cannot be classed as cottages or peasant buildings. They form themselves in to three general groups: châteaux, manors, and the larger farms or farm groups. It is in these types that perhaps the more interesting studies of French rural architecture exist, for the fact that in them is discernible a more or less conscious attempt at a truly architectural design, differentiating them at once from the simpler dwellings, where the result, however attractive, has been arrived at by unconscious native artistry and the pleasant combination of local materials.

The châteaux illustrated are few in number, for it has been our idea to avoid buildings of any great pretension, the ones included being the smaller ones in most cases.

Château Gratot, on Plate 75, is just such a one, a group of buildings around a court, unsymmetrical except for the farm buildings flanking the entrance. The château is one of those early Normandy examples, quite mediæval in every way.

The Château Brécy, a Renaissance group, near Bayeux in Calvados, shown on Plates II6, II7, II 8, and II9, is the most elaborate château that has been included. The buildings, however, are small and comparatively little known, though they form, with the gardens, an unusually complete and beautiful whole. The most interesting feature is the plan, owing to the use of the sloping site with a walled garden of ascending terraces, rising up to a richly ornamented gateway, which opens toward farm lands beyond. No element of symmetrical treatment has been omitted, except slight variations in the court facades of the farm buildings which flank the entrance-court. As may be seen from the plates, the stone detail of gateway, doorways, and other detail has been richly and beautifully carved. In the garden the wall treatment of the lowest terrace with Doric and Ionic pilasters, the arrangement of terraces, the detail of gates, steps, and walls, have been attractively handled.

Château le Pin (Plate I2I) has well-proportioned and nicely composed facade, made lively with the contrasting bands, quoins, and panels of stone and brick. Note that the fenestration of the central pavillion is not symmetrical, and yet the result, judging from the photograph, has been insured thereby from being too dry.

Plate 132 shows an interesting and original wrought-iron gateway, effective against the château beyond, which itself is rather good in mass and composition. The design of the château is attributed to J. H. Mansart. 


\section{CHÂTEAUX, MANORS, AND FARM GROUPS}

Château de St. Germain-de-Livet (Plate I24) is a sixteenth-century building of composite architecture. The château proper has its wall in that colorful pattern of flint and salmon-pink bricks, very effective play of color resulting, if the eye is not distracted by too much of it at a time.

Plate I25, a sketch of the Château de Cantepie, shows the original building with the towered pavillion of more modern design at the left rear, which has the style but not the character of the old portion. The façade in the sketch suggests a very excellent and clever treatment for a two-and-a-half-story house, the breaking of the eaves over the second-story windows and under the dormers serving to tie the composition together in an attractive manner. Note the use of high finials at the peak of the dormer roofs.

Manors, smaller than châteaux as a rule and more pretentious than simple farmhouses, are scattered throughout the length and breadth of France. They were built after the passing of Feudalism by the more prosperous independent farmers who, without being of noble birth, had yet more position and wealth than the peasants. It is in this type of building that many fine examples exist, for a definite attempt at design has been made without the more formal pretensions of a château. The buildings usually are several: a main dwelling and farm buildings flanking a court, detached or connected with a masonry wall, as well as an entrancelodge or gateway and other isolated buildings, such as pigeon-houses or wellhouses. The use of the court wall tends to tie the whole together and has brought about many interesting effects. Such a result is illustrated on Plate 72, where the wall between the flanking farm buildings has been carried the full height of the building wall. The continuity of the eave-line is largely accountable for the pleasing result.

The encircling wall of the manor near Demigny, also shown on Plate I54, has been capped with tile roofing. Note the main arched entrance for farm vehicles and the smaller entrance at the side for pedestrians.

The manor near Libourne (Plates I5I, I52, I53) is of the southern or Italian type. On account of the thick trees set about it and on the garden terrace it was almost impossible to photograph. The raised grass terrace enclosed with a balustrade and bordered with a moat is the most attractive and unusual feature. There are four big linden-trees on the terrace, spaced carefully in relation to the terrace and house, which add much interest to the garden side of the building.

The garden-house near Hennebont, on Plates 74 and 76 , overlooks the Blaret River. The loggia treatment with brackets to the garden-wall, the quaint mansard roof, overhanging dormer roofs, and little tower make a very pleasing composition.

The farmhouse at St. Pierre-le-Viger, shown on Plates 83 and I I4, is an example of the larger type of farm that has numerous buildings connected by a wall forming a very large court planted with an orchard of fruit-trees. Though the buildings are not symmetrical in mass or location, there is an axis line established 


\section{CHÂTEAUX, MANORS, AND FARM GROUPS}

through the entrance-gates and the main farm residence, and the planting of the trees has been balanced on this axis. The farmhouse at Esclarelles, on Plate 85, shows an unusual beaver-tail roof, which carries down close to the ground. The farmhouse, on Plate 90, has a good treatment of mass for a sloping site and shows the frieze-board usual in that locality over the windows, and a rather typical open shed for vehicles. In the farm group, on Plate 95, is a good example of the farmcourt, beyond the entrance-pavilion, with the flanking sheds and farmhouses, barns, etc., forming the other sides of the square. There is something well knit and at the same time picturesque about these groups.

The manor at Arques-la-Bataille (Plates 97 and I56) is the rather well-known Normandy manor, where the stable shown on the plate is almost a replica of the main dwelling, separated from it by a garden. The stepped gables and nicely fenestrated façades have been enlivened by the judicious use of flint inserts in pattern and bands. Another example of such ornamentation of brickwork is shown on Plate 99, the inserts in the cornice having more lively decorative effect than true modillions. On Plate 105 is an example of brick set to form quoins and bands, while Plate Io6 shows an all-over wall pattern. The farm building near St. Léger (Plate III) is interesting for its roof and mass, the photograph unfortunately being valuable on that account only. Plates II2, II3, and II5 give a very good idea of the half-timber work of Normandy, showing it to be truly structural.

The farm near Gourdon, in the province of Lot, Plate I45, has a very interesting towered building for the residence of the farmer, while the sheds and barns have been tied in to the house with a long ridged roof whose eaves hug the ground. Plate $\mathrm{I} 44$ shows the use of glazed tile in patterns on the roof, the ridge-lines set off with white cement.

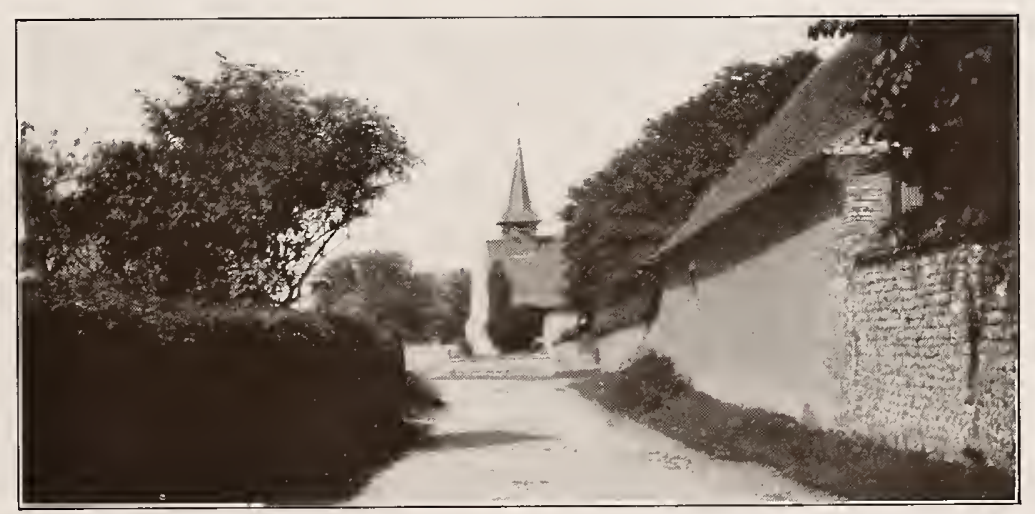





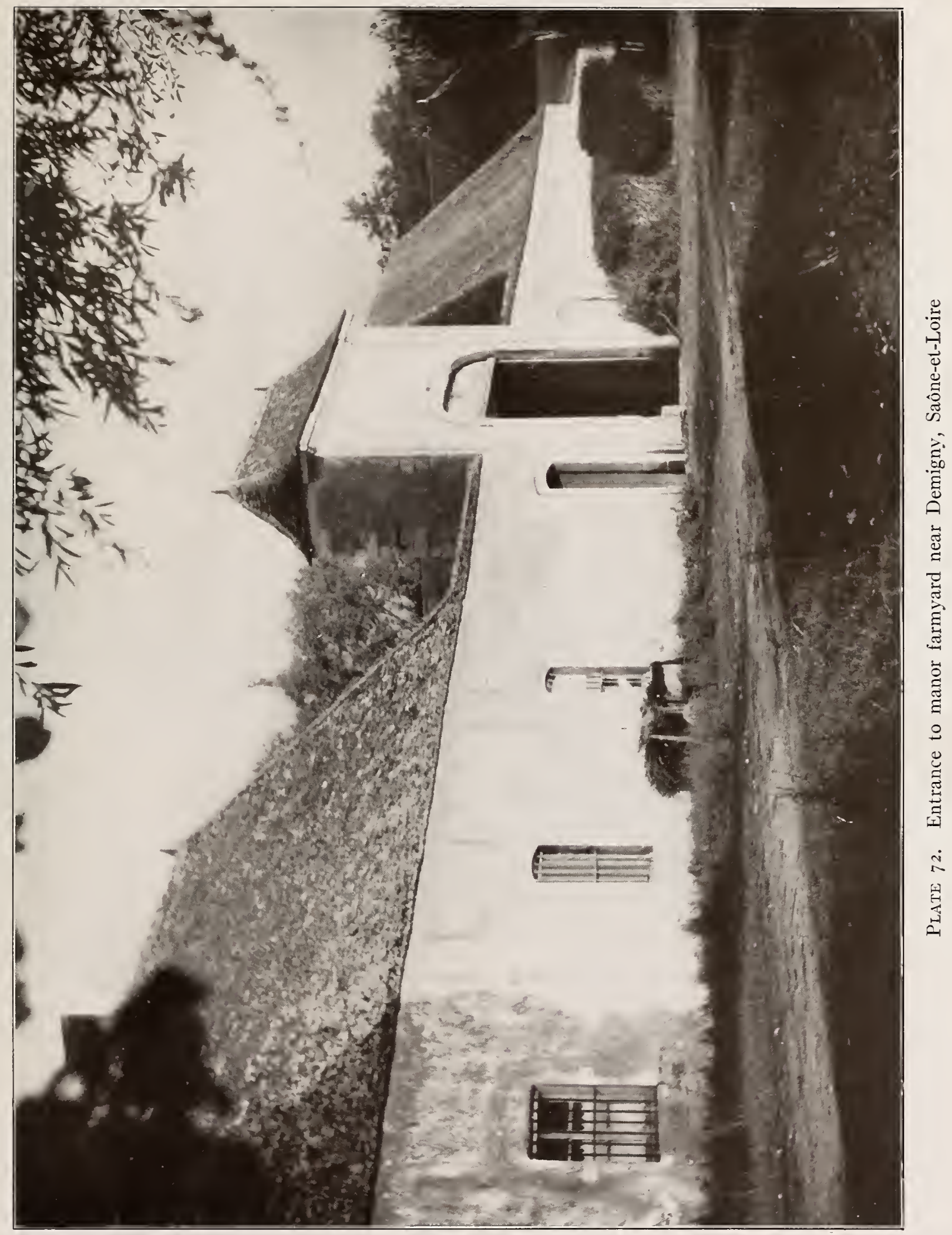





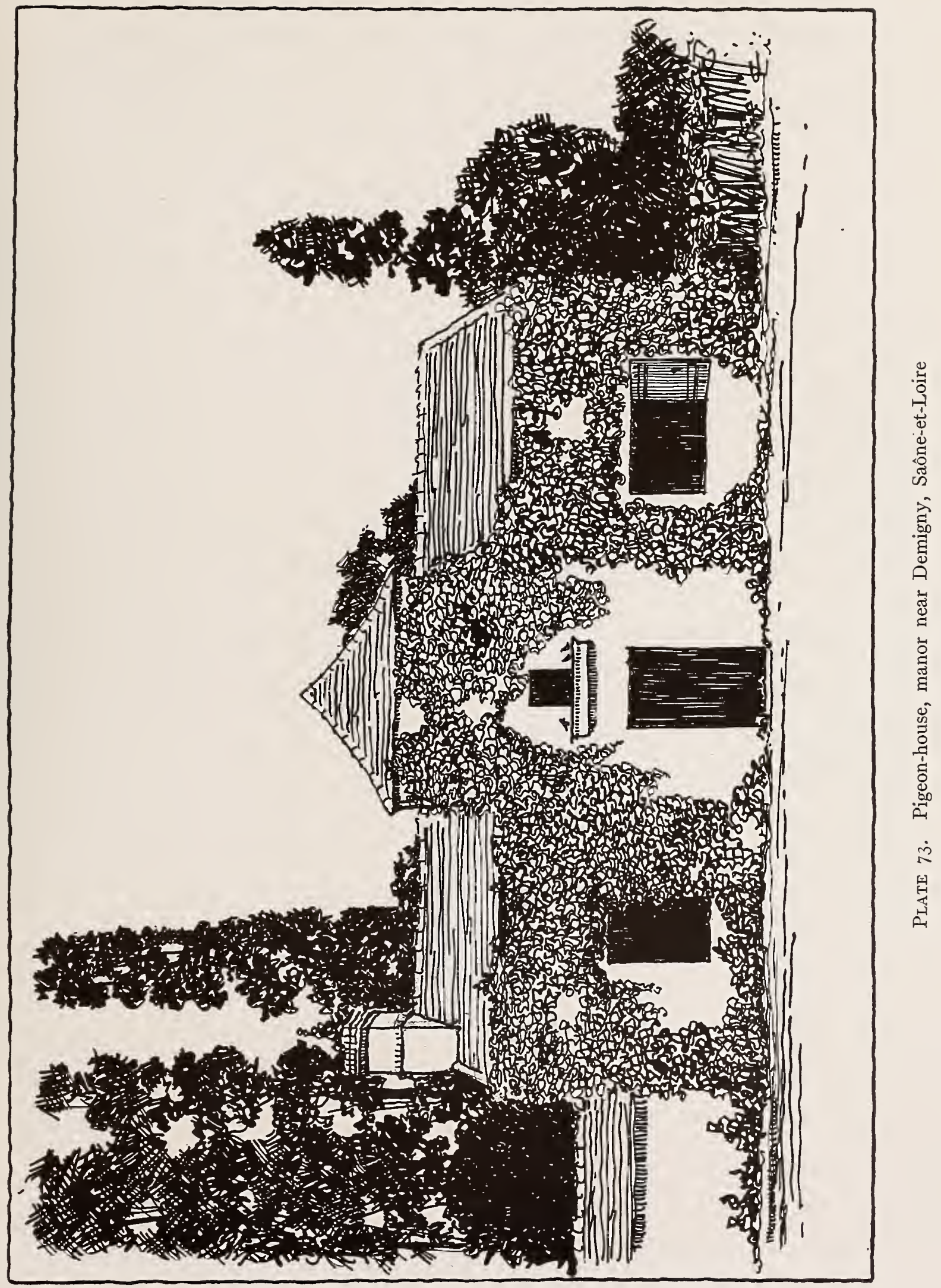





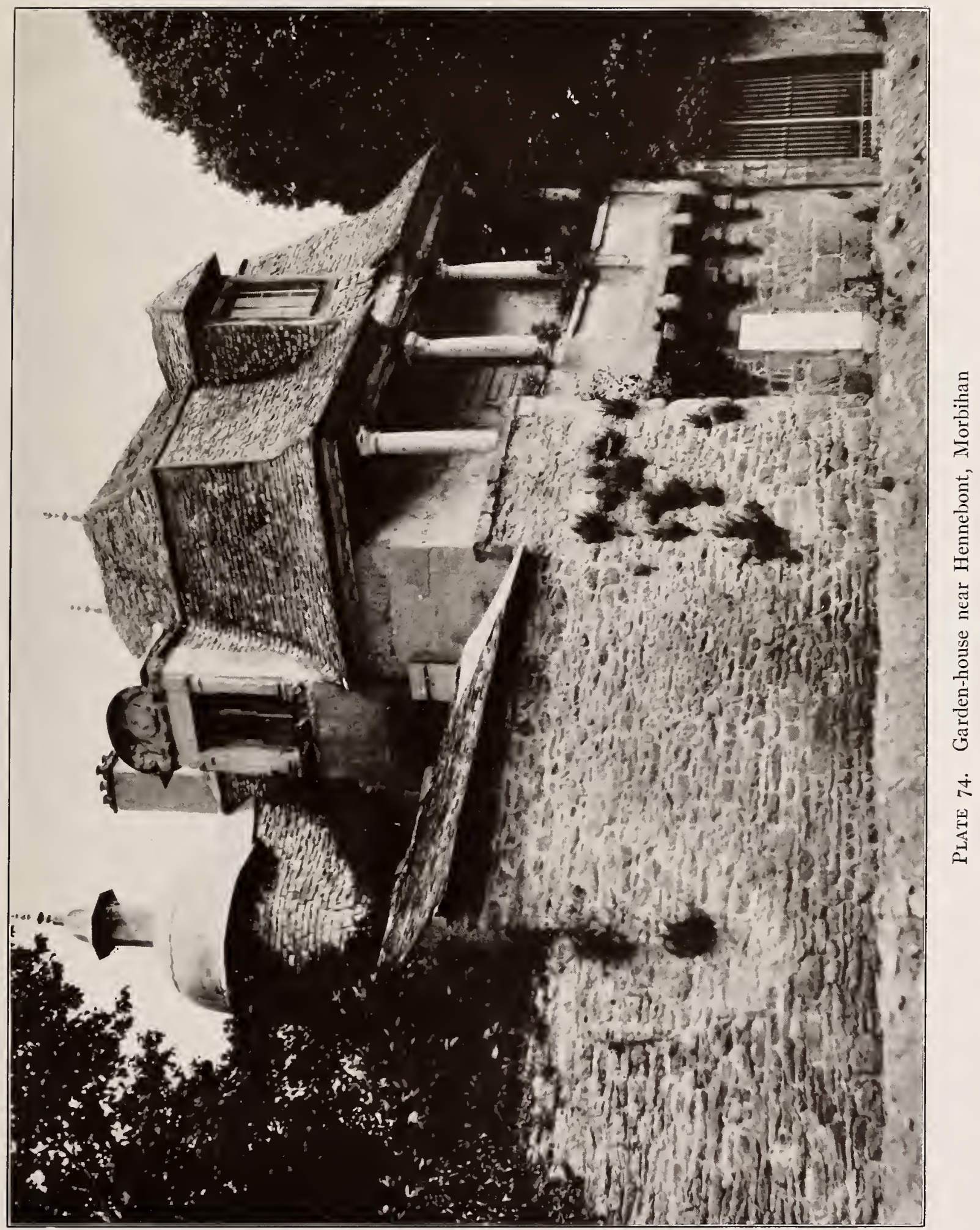





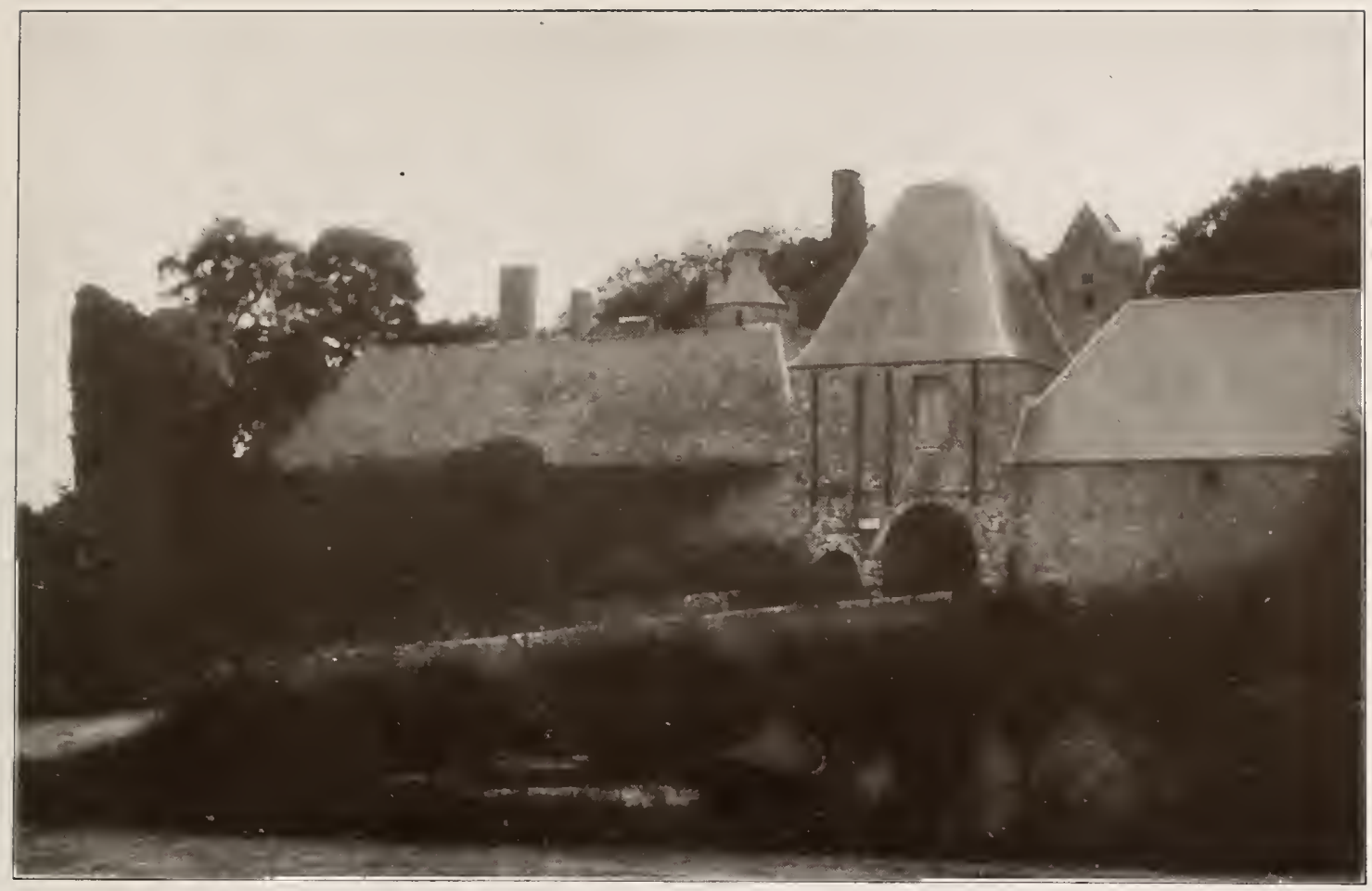

Plate 75. Château Gratot, near Coutances, Manche

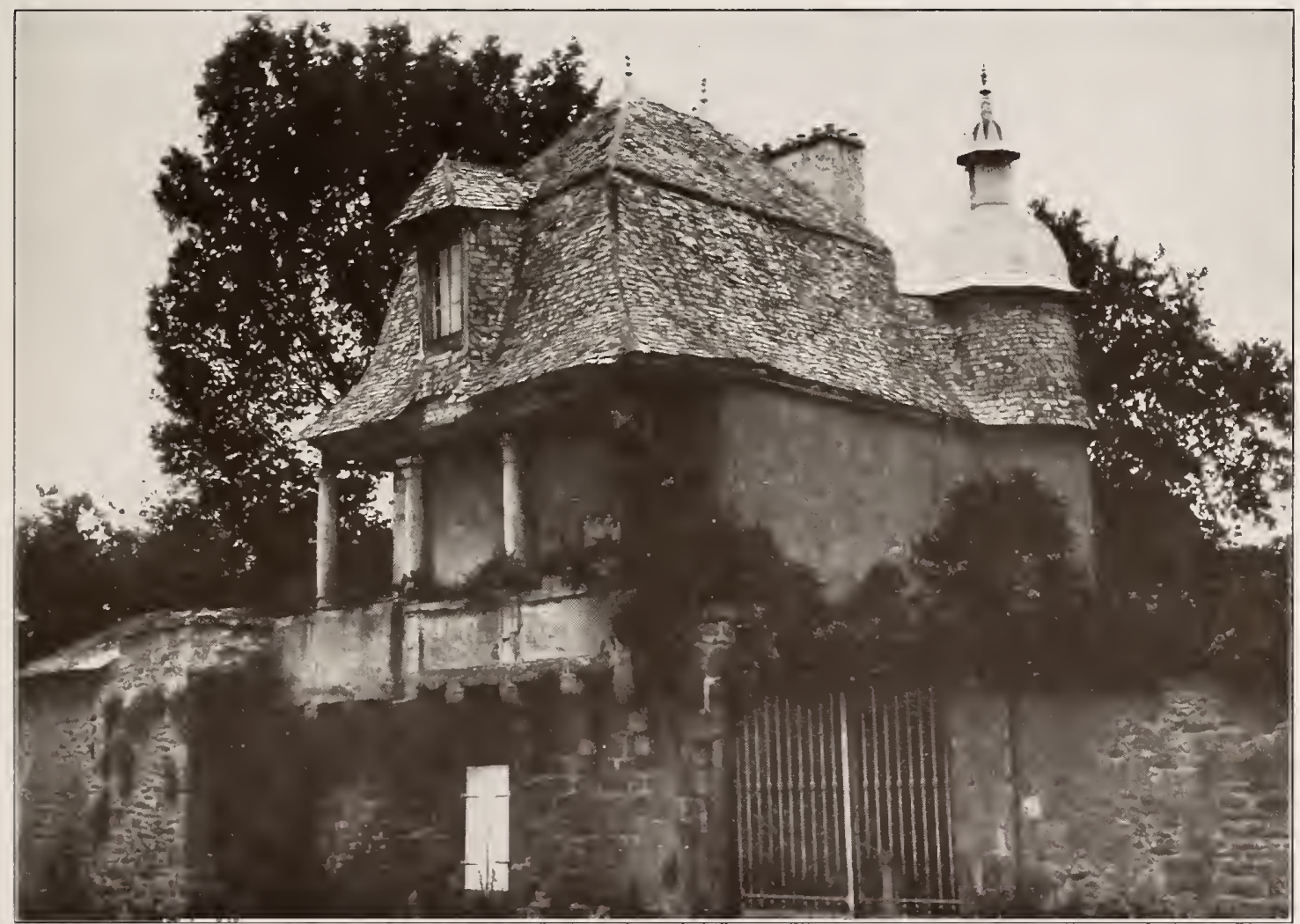

Plate 76. Garden-house near Hennebont, Morbihan 



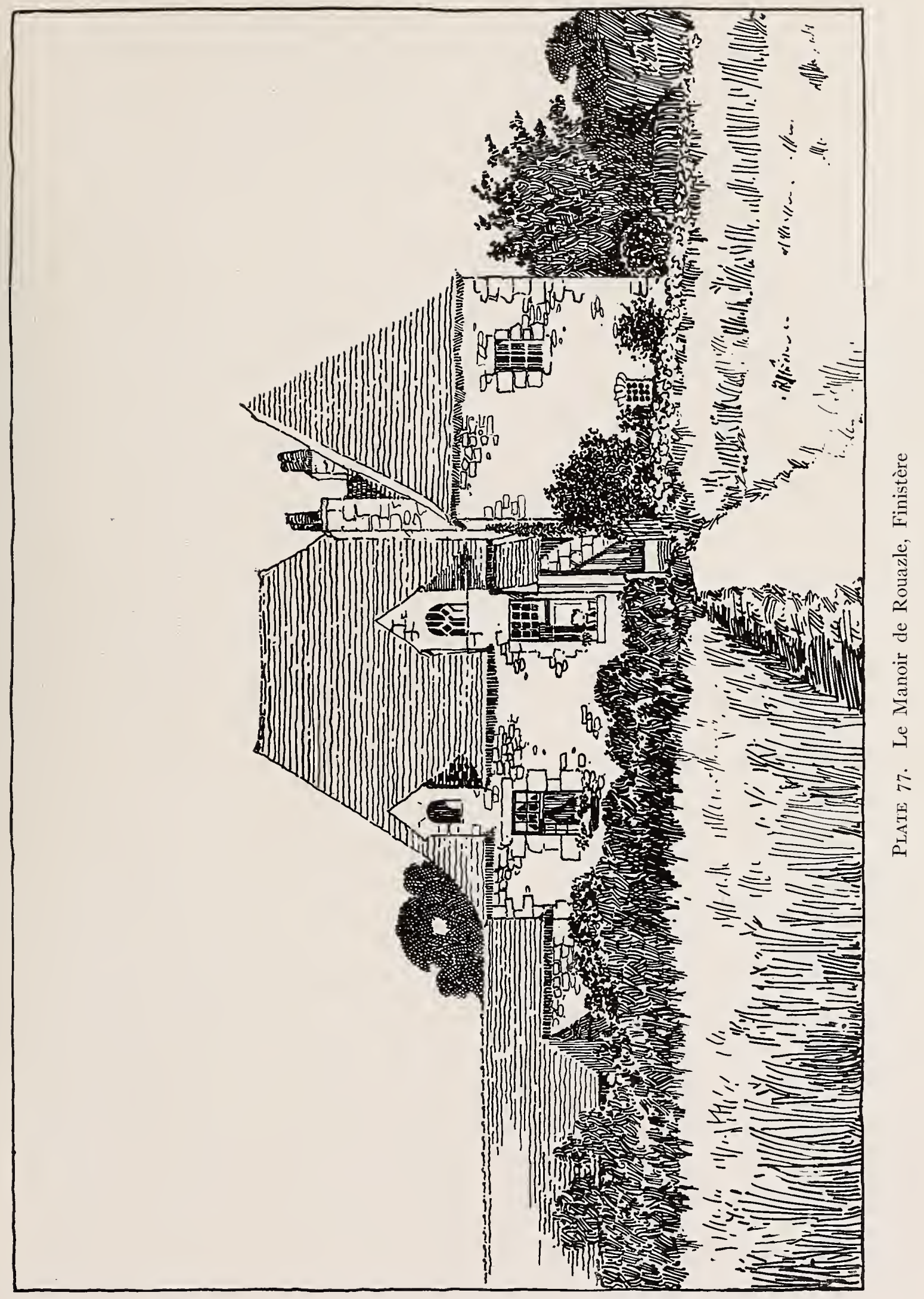





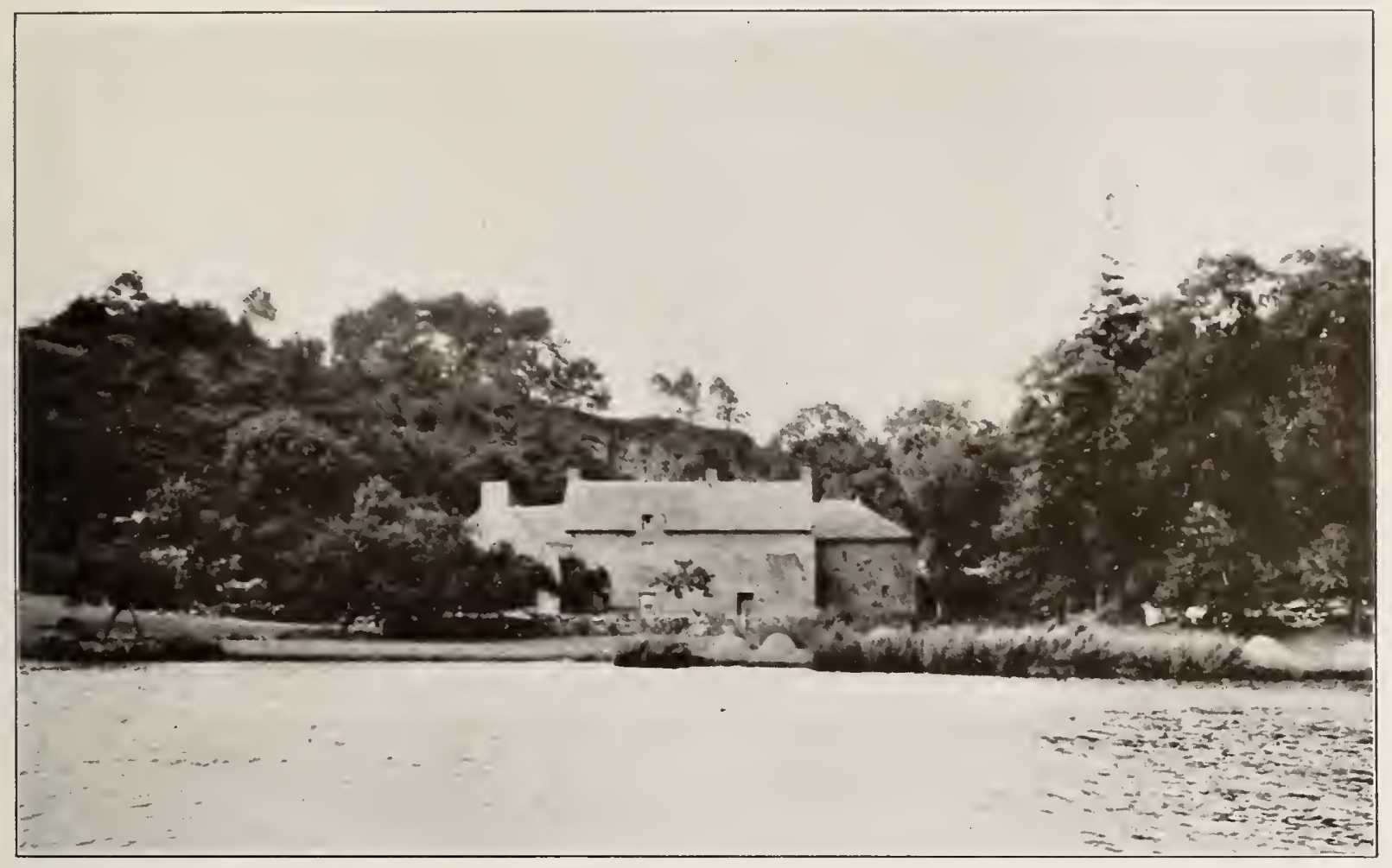

PLAte 78. Farm on Blaret River above Hennebont, Morbihan

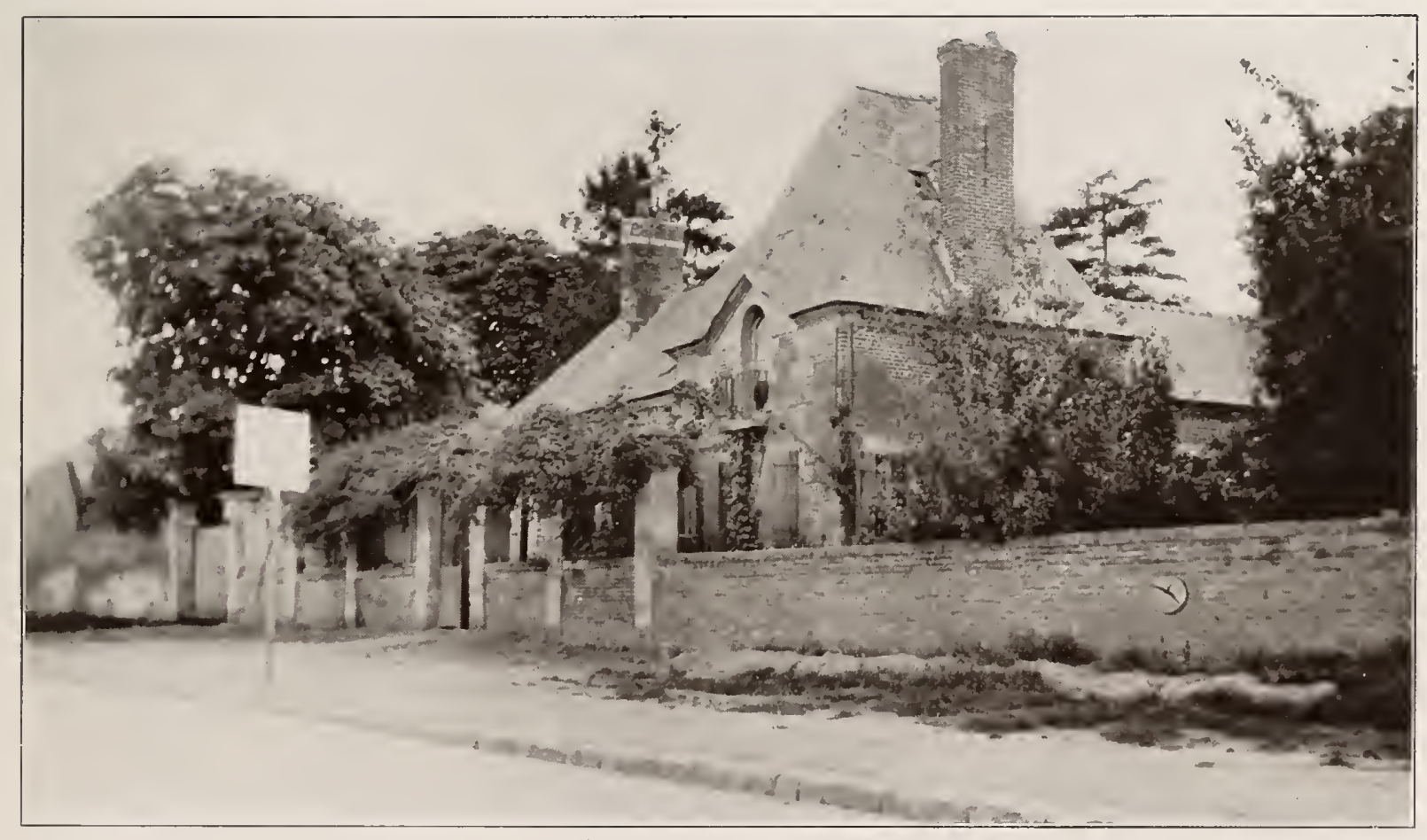

Plate 79. House at Guiscard 



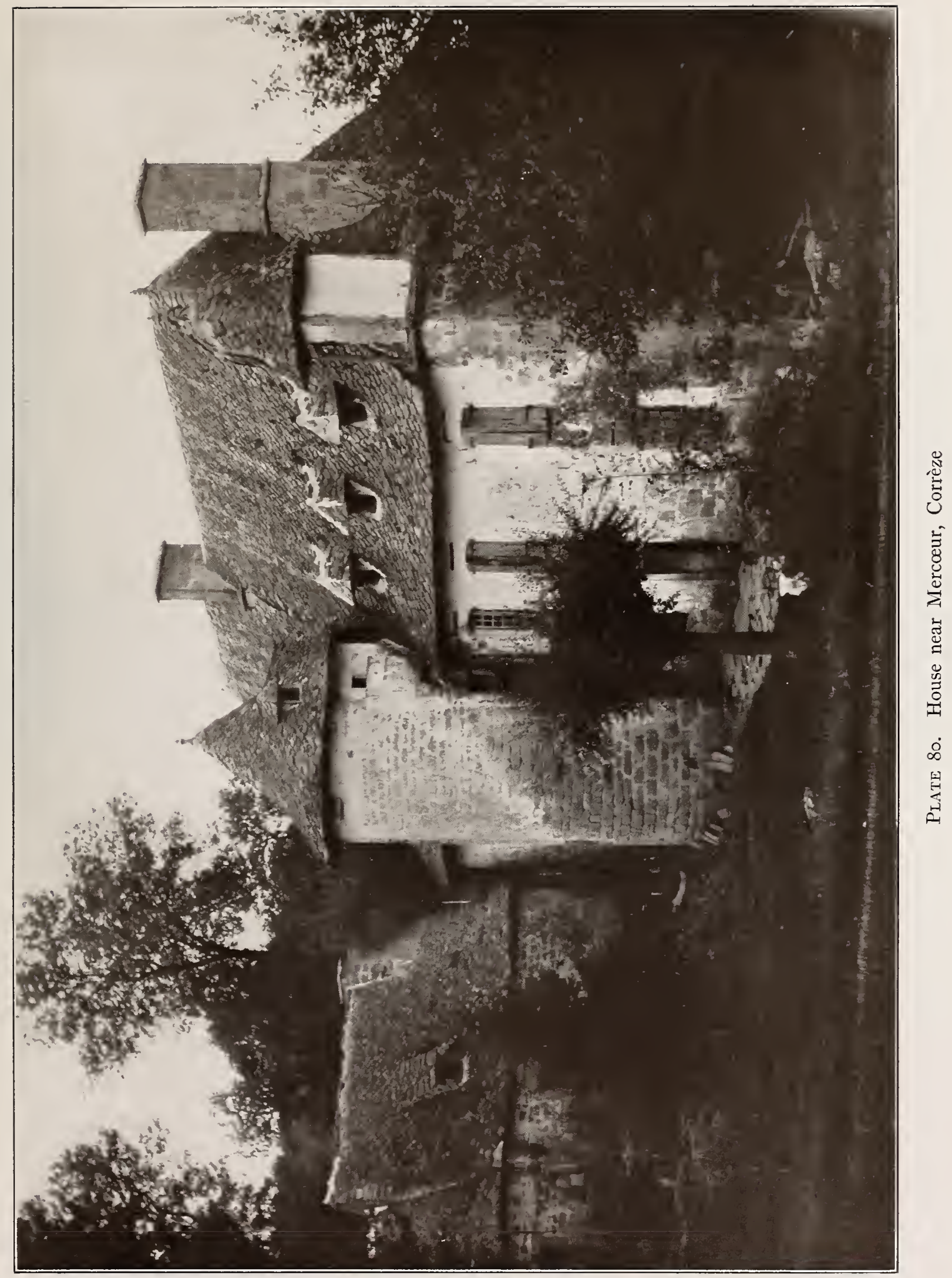





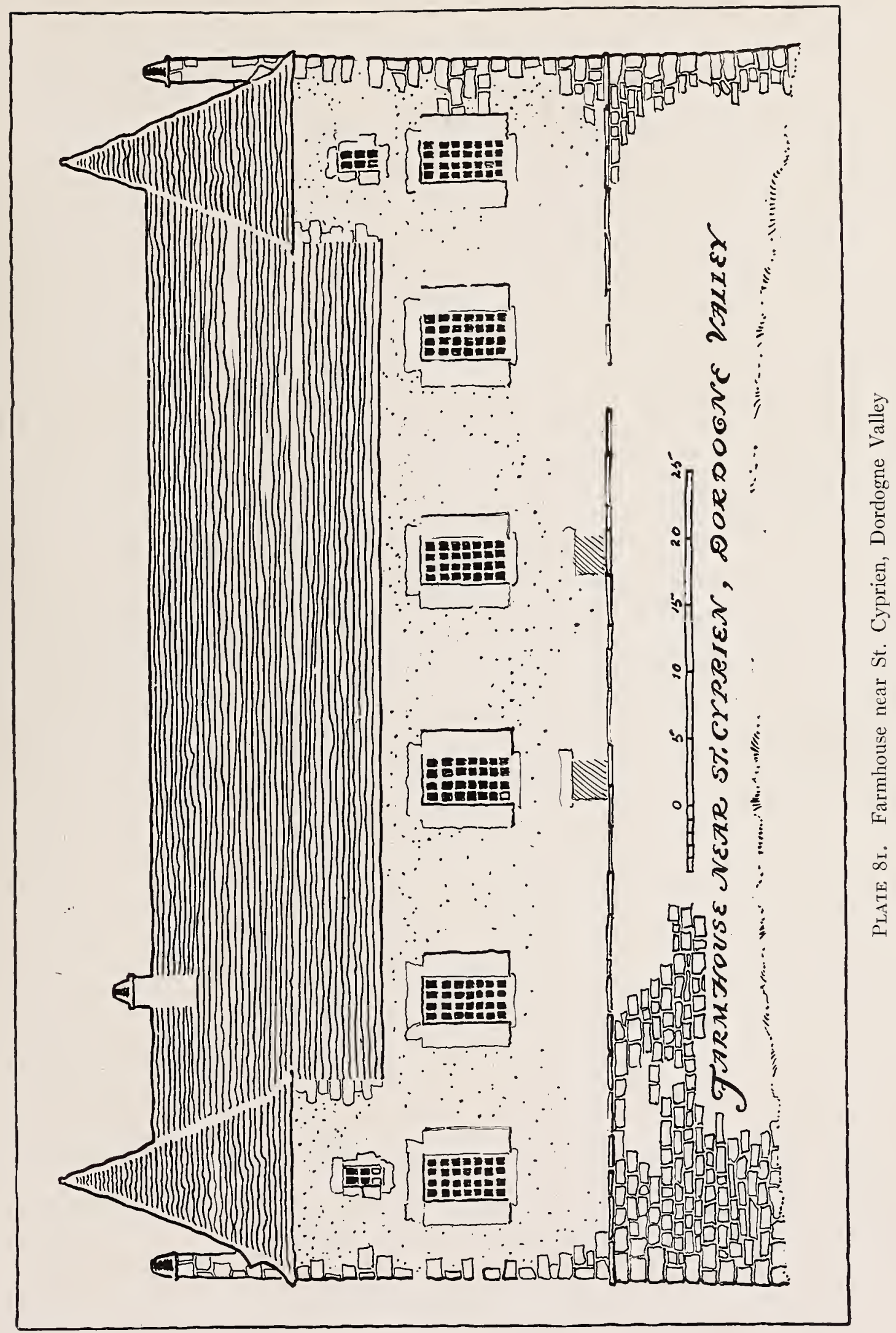





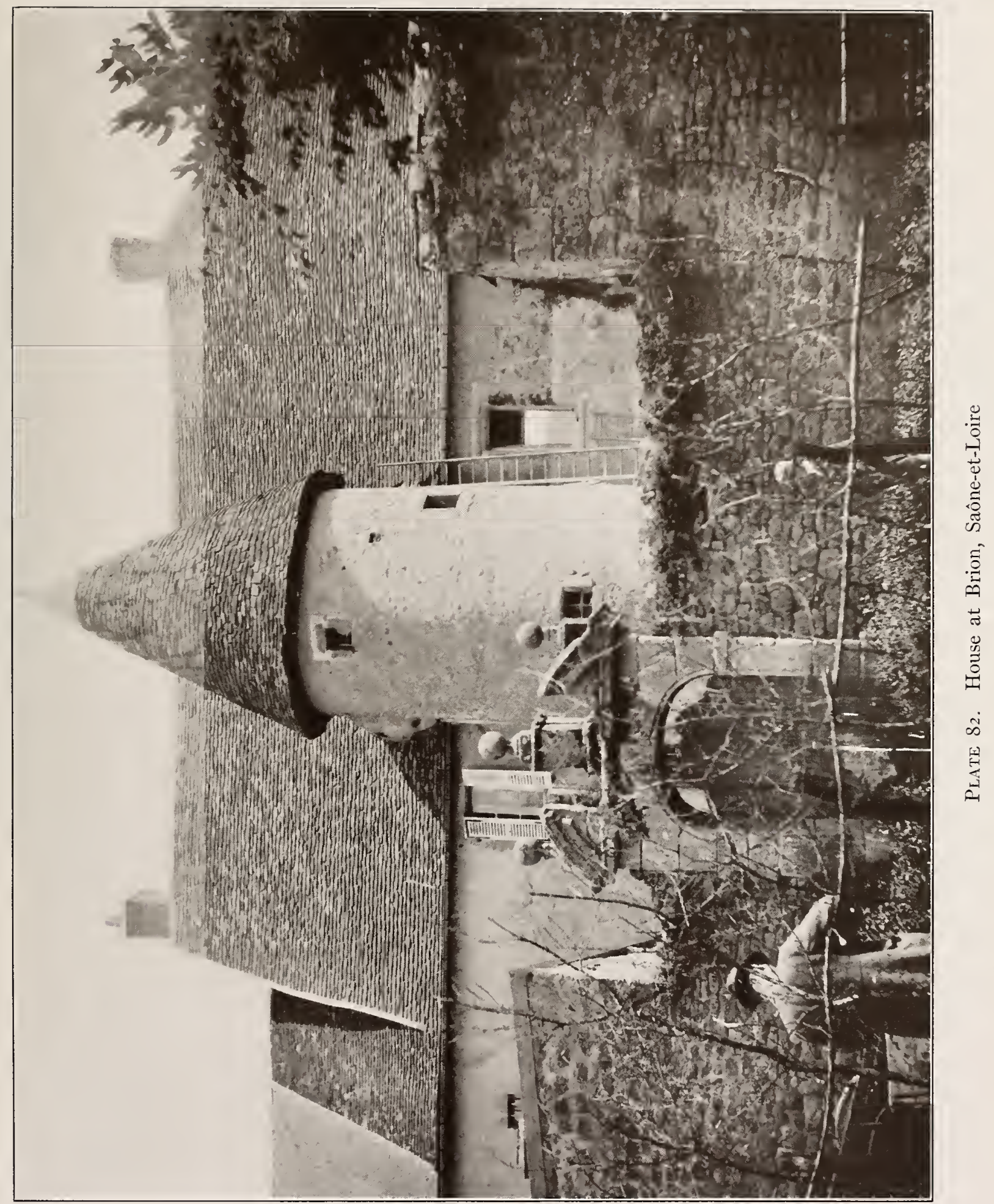





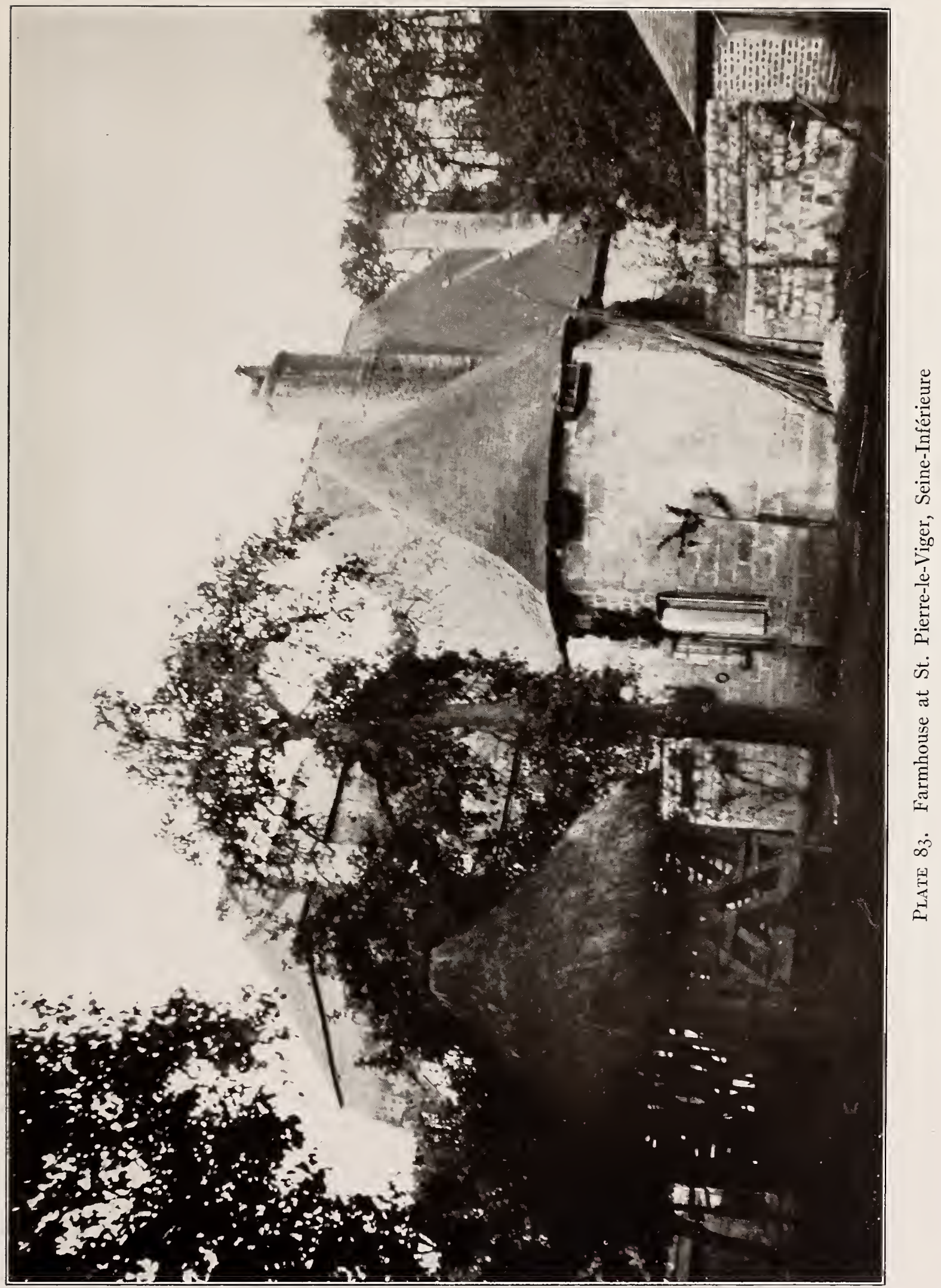





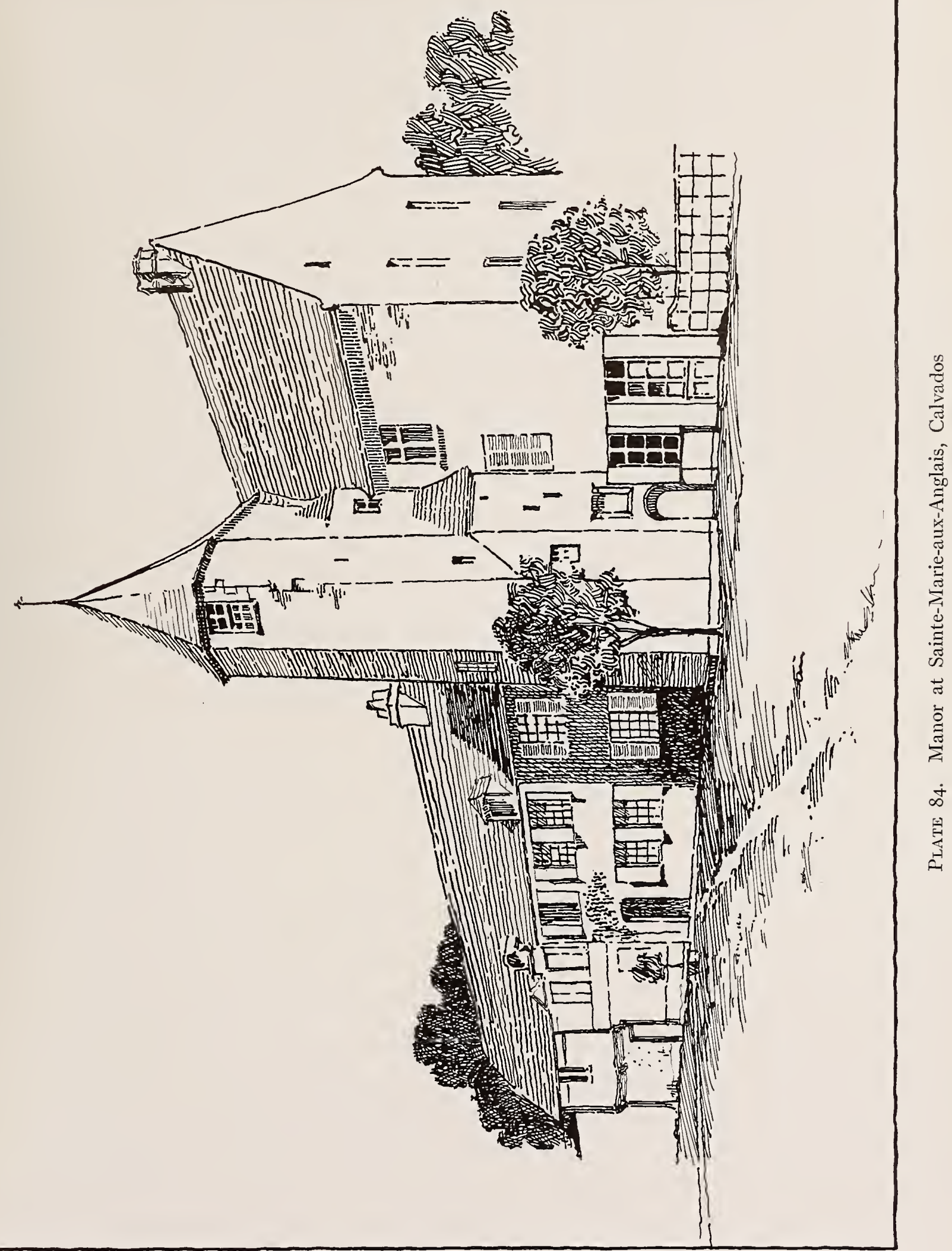





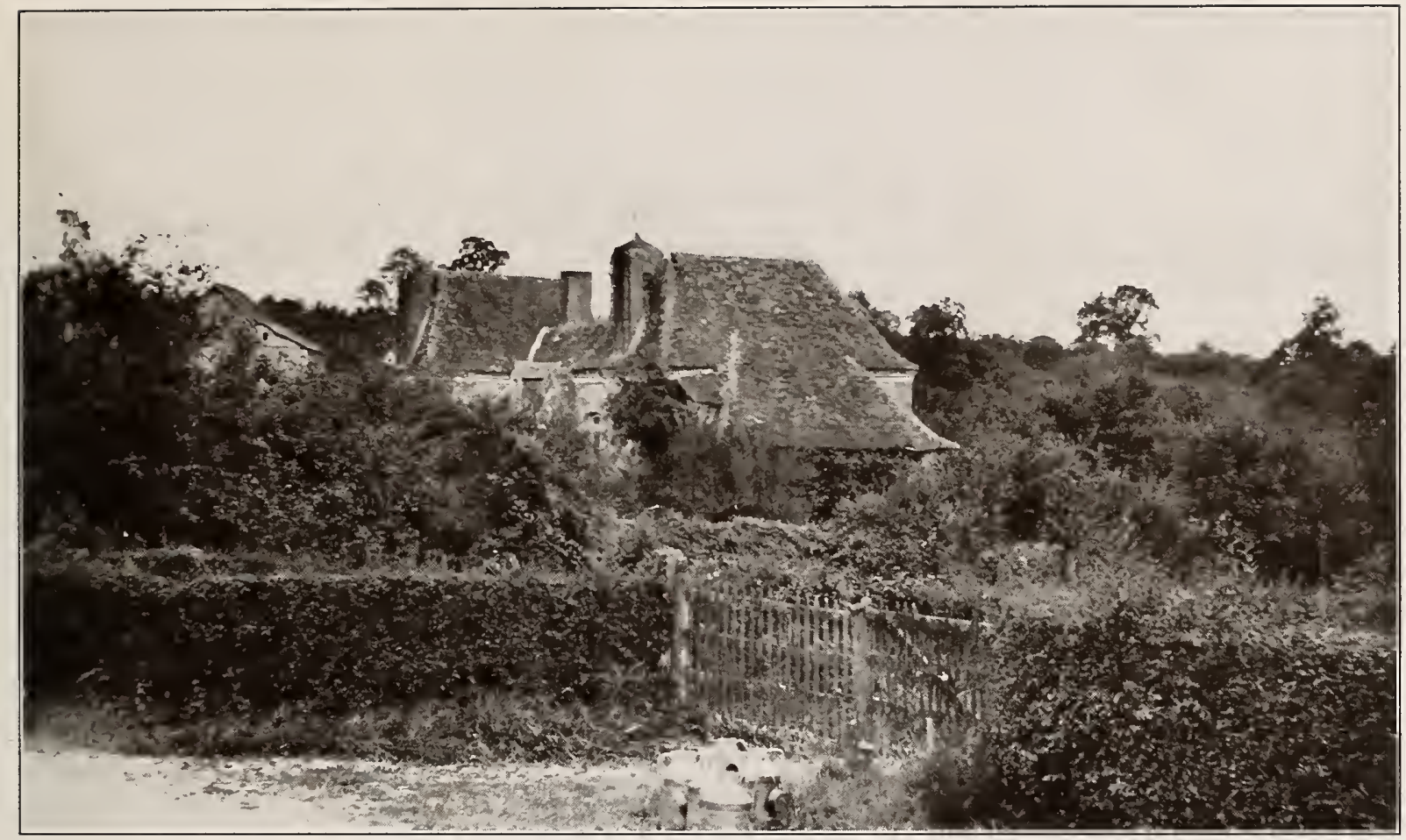

Plate 85. House at Esclarelles, Seine-Inférieure

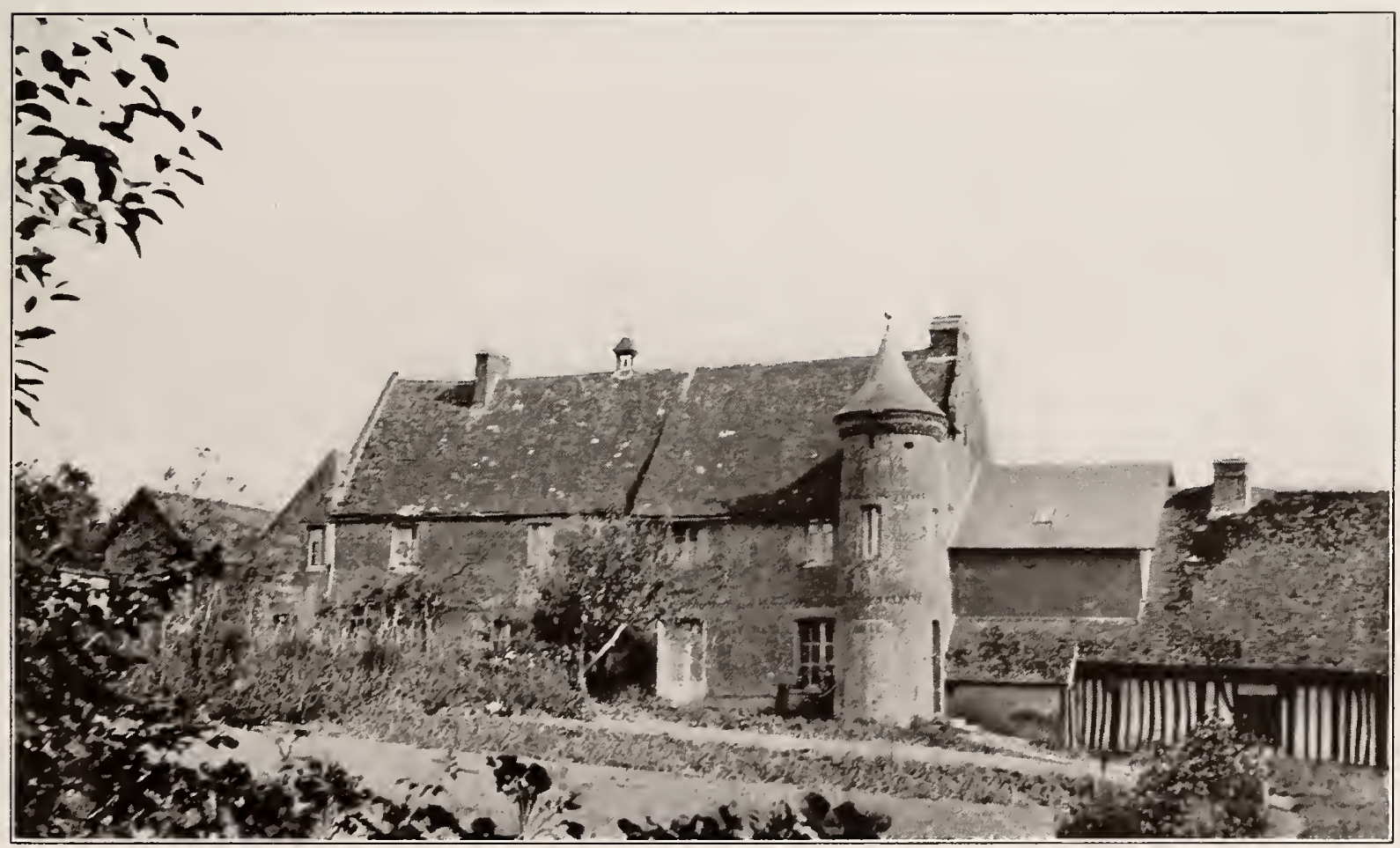

Plate 86. Manor near Freulleville, Seine-Inférieure 



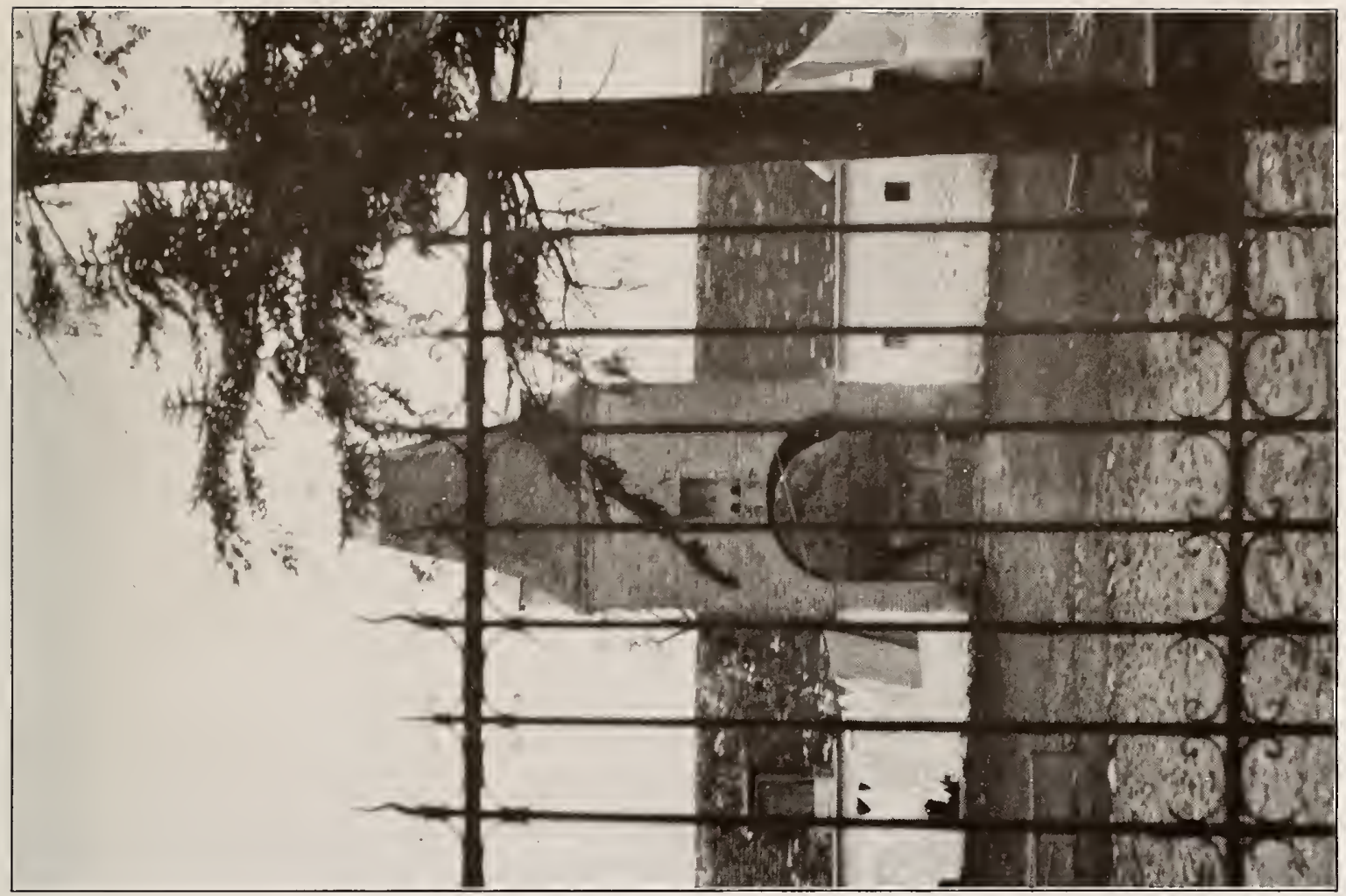

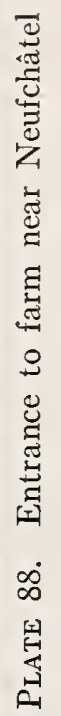

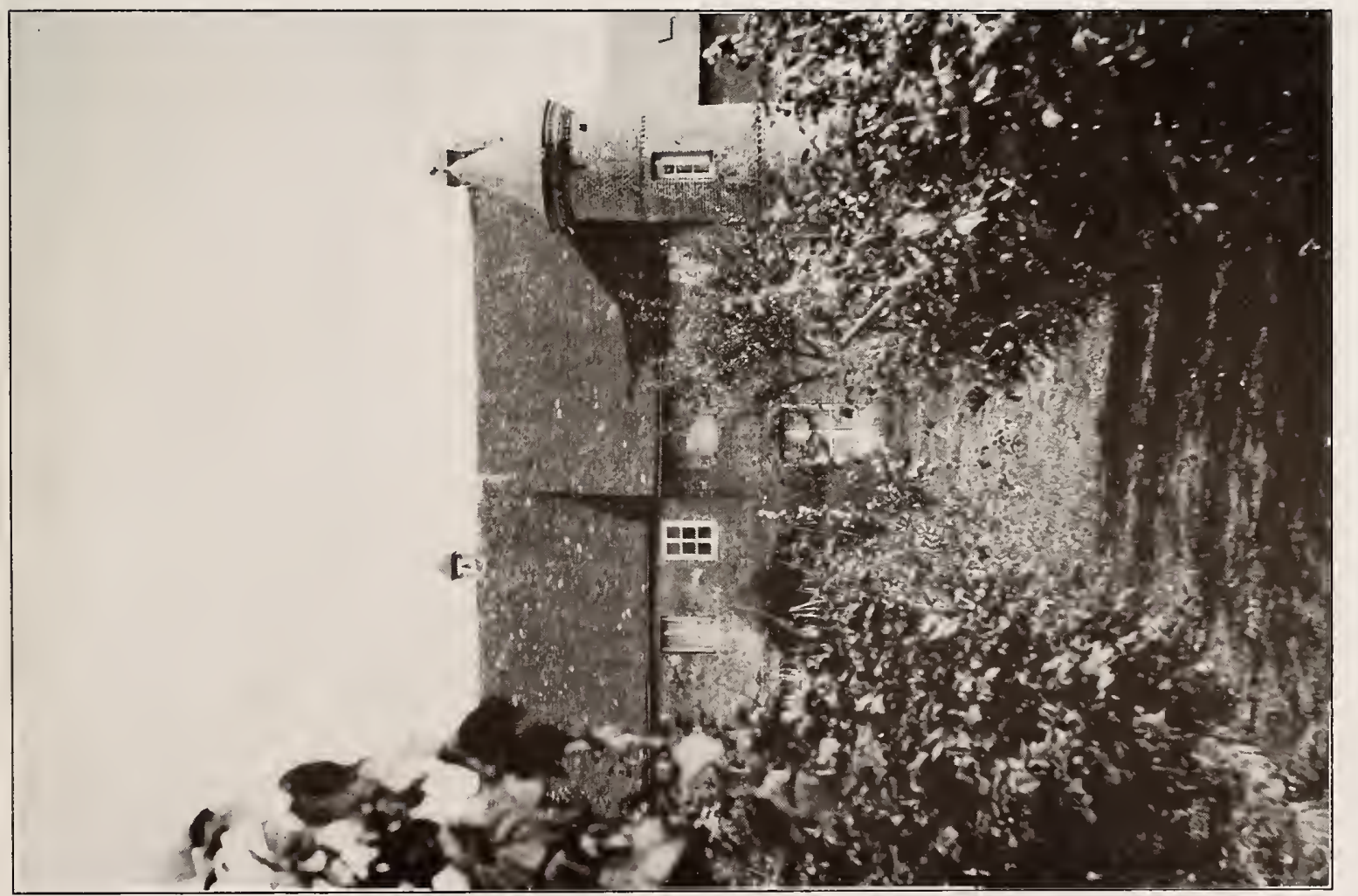

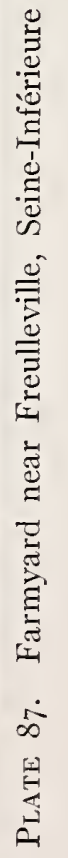





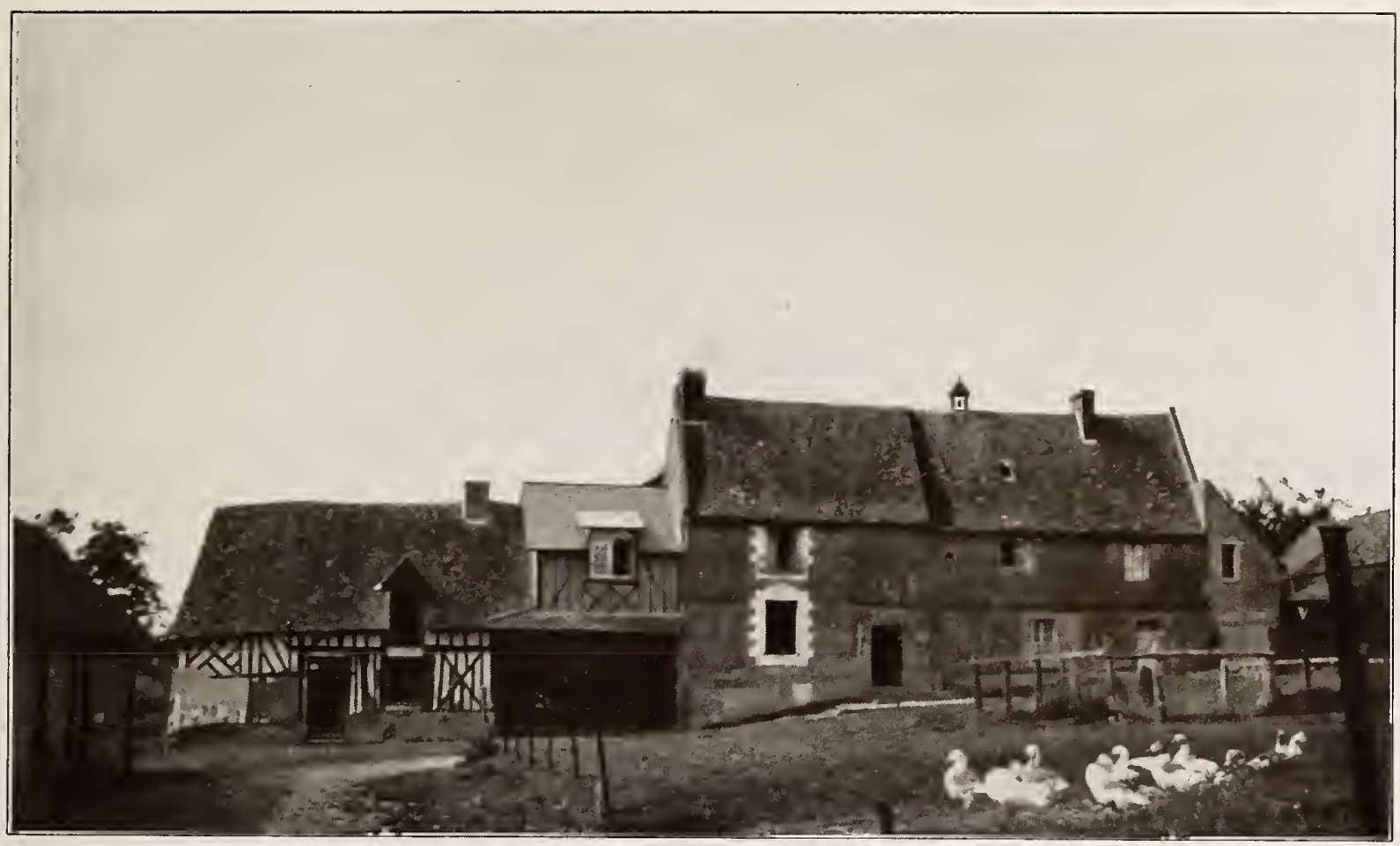

Plate 89. Manor farmyard near Freulleville, Seine-Inférieure

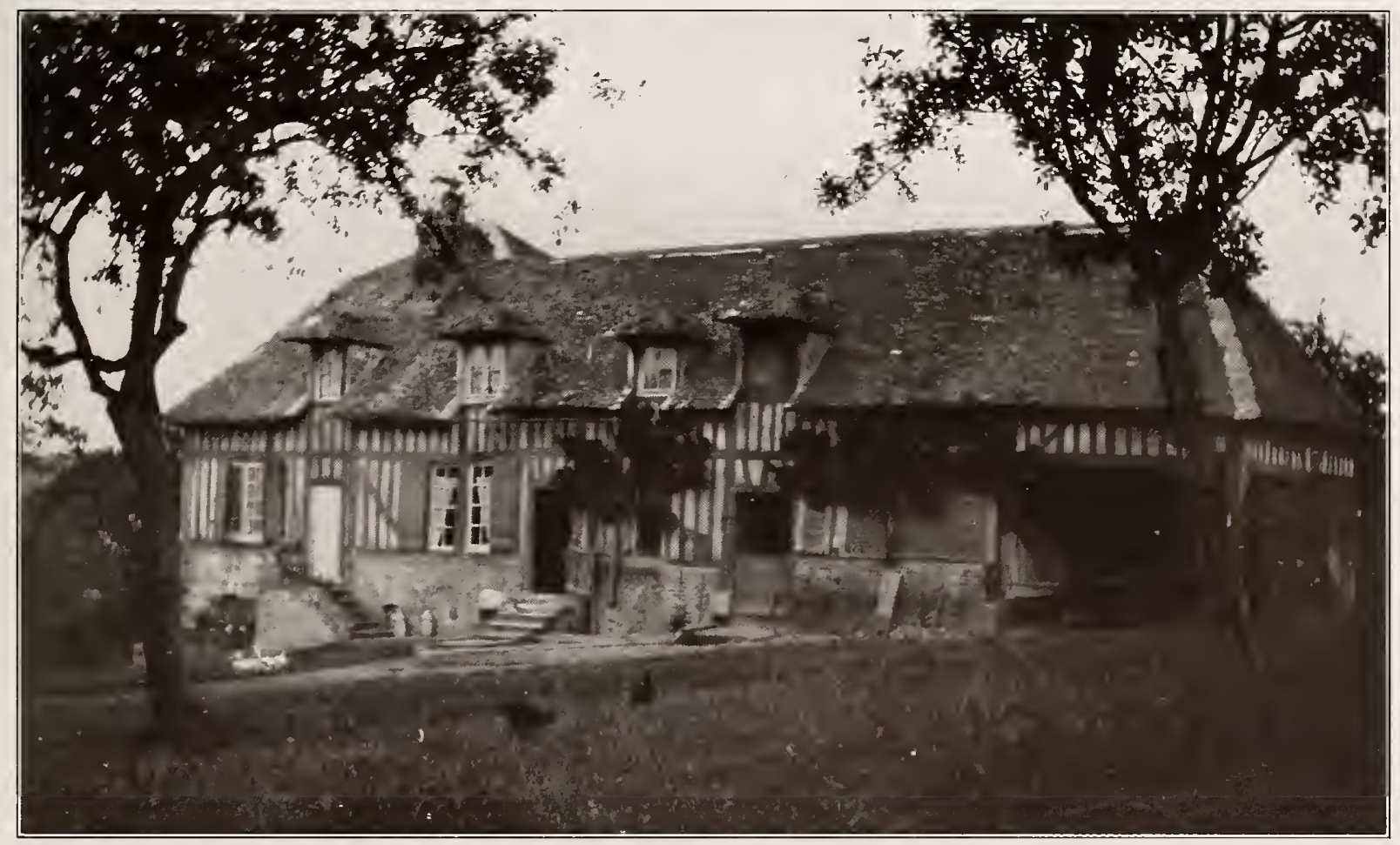

Plate 90. Farmhouse near Lisieux, Calvados 



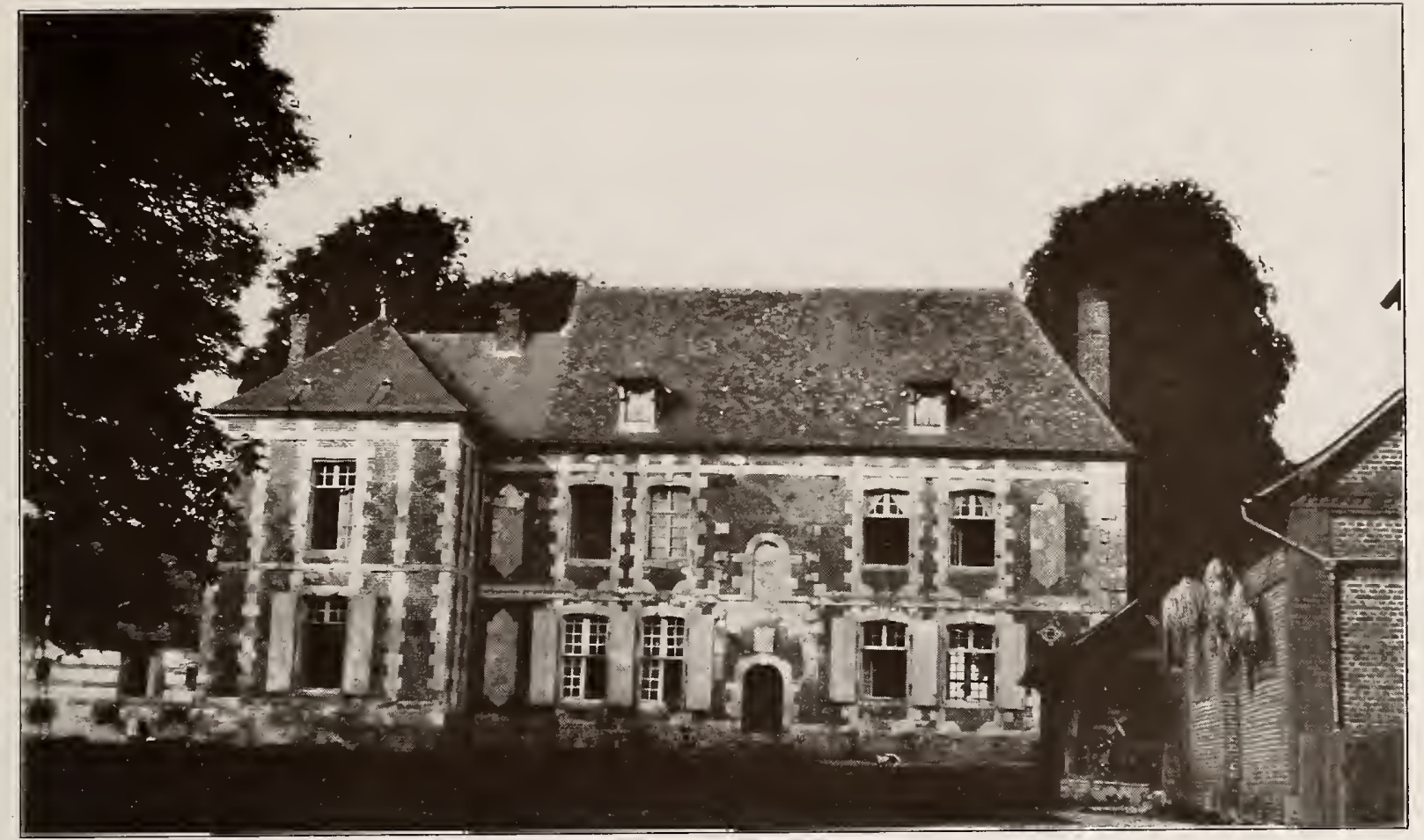

Plate 9I. Farmyard side of manor near Bures, Seine-Inférieure

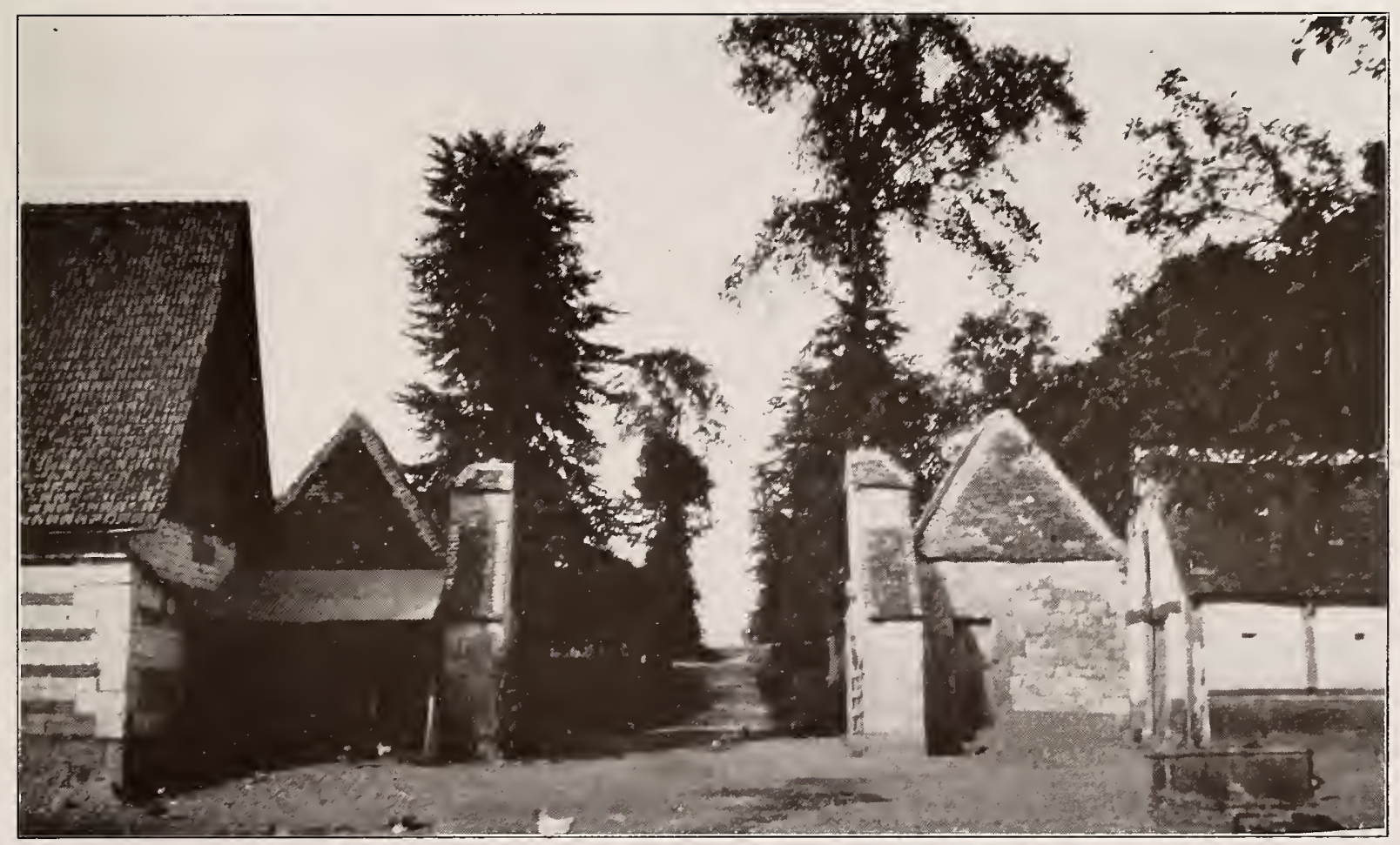

Plate 92. Manor gate near Bures, Seine-Inférieure 



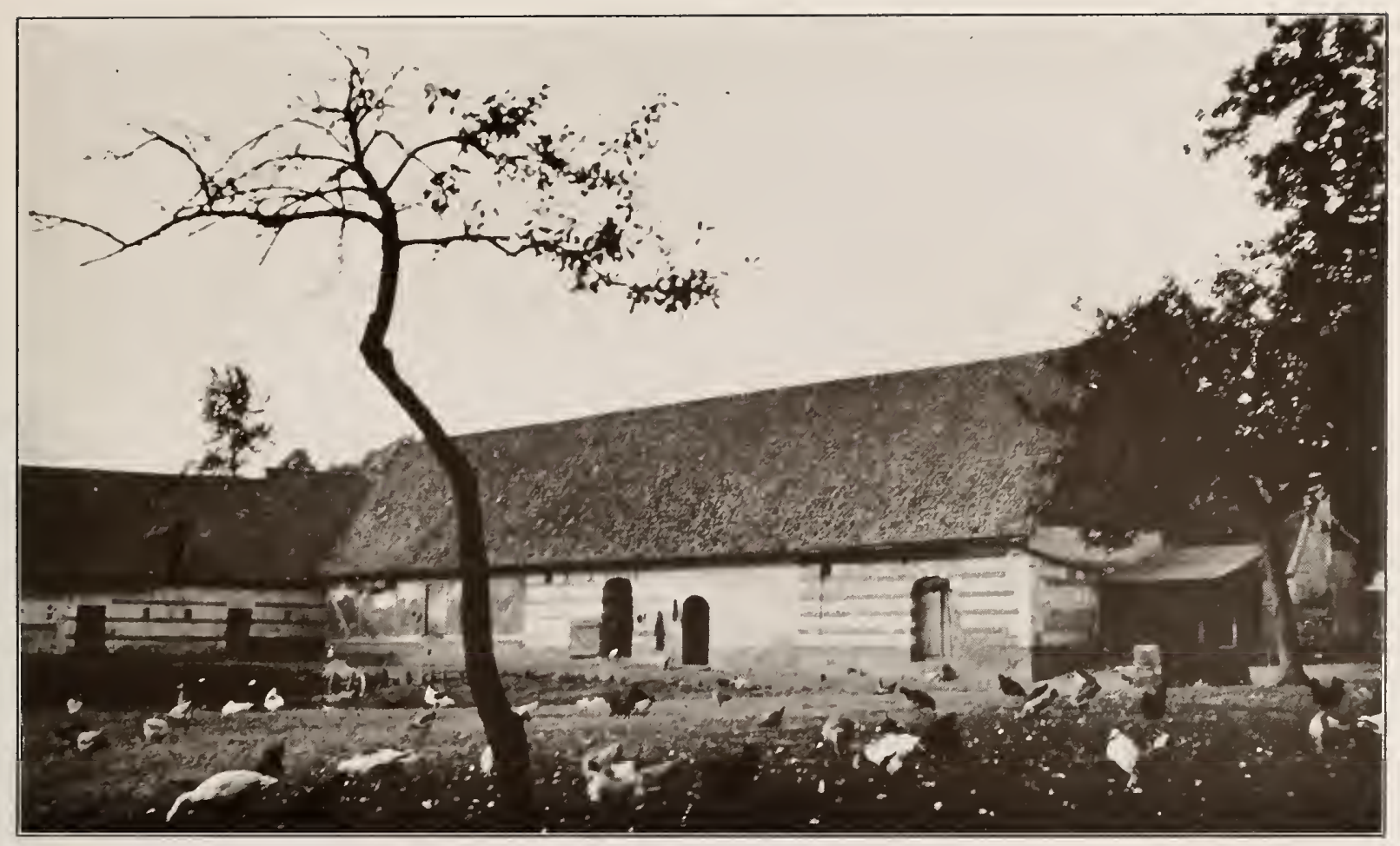

Plate 93. Farmyard, manor near Bures, Seine-Inférieure

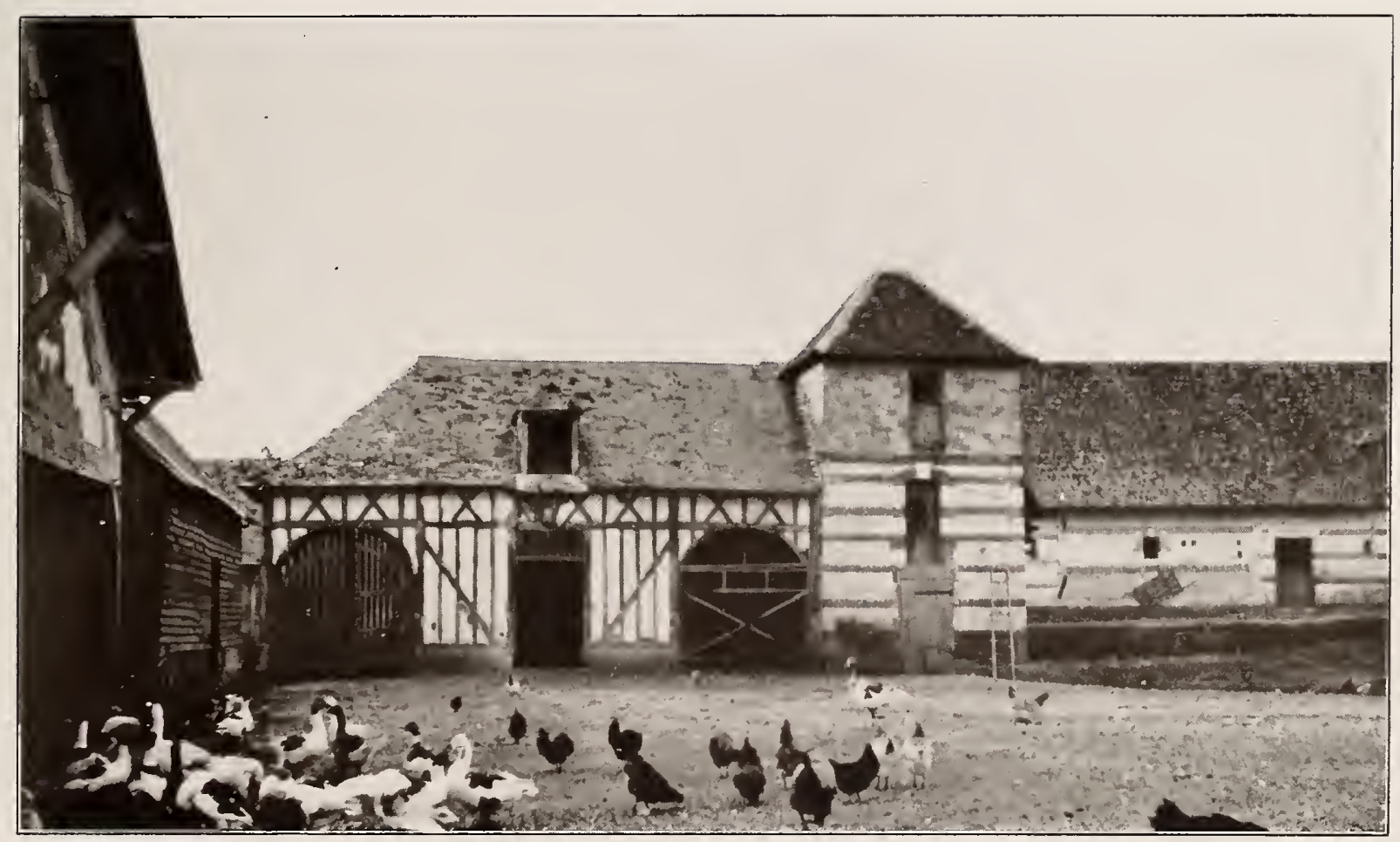

Plate 94. Farm buildings, manor near Bures, Seine-Inférieure 



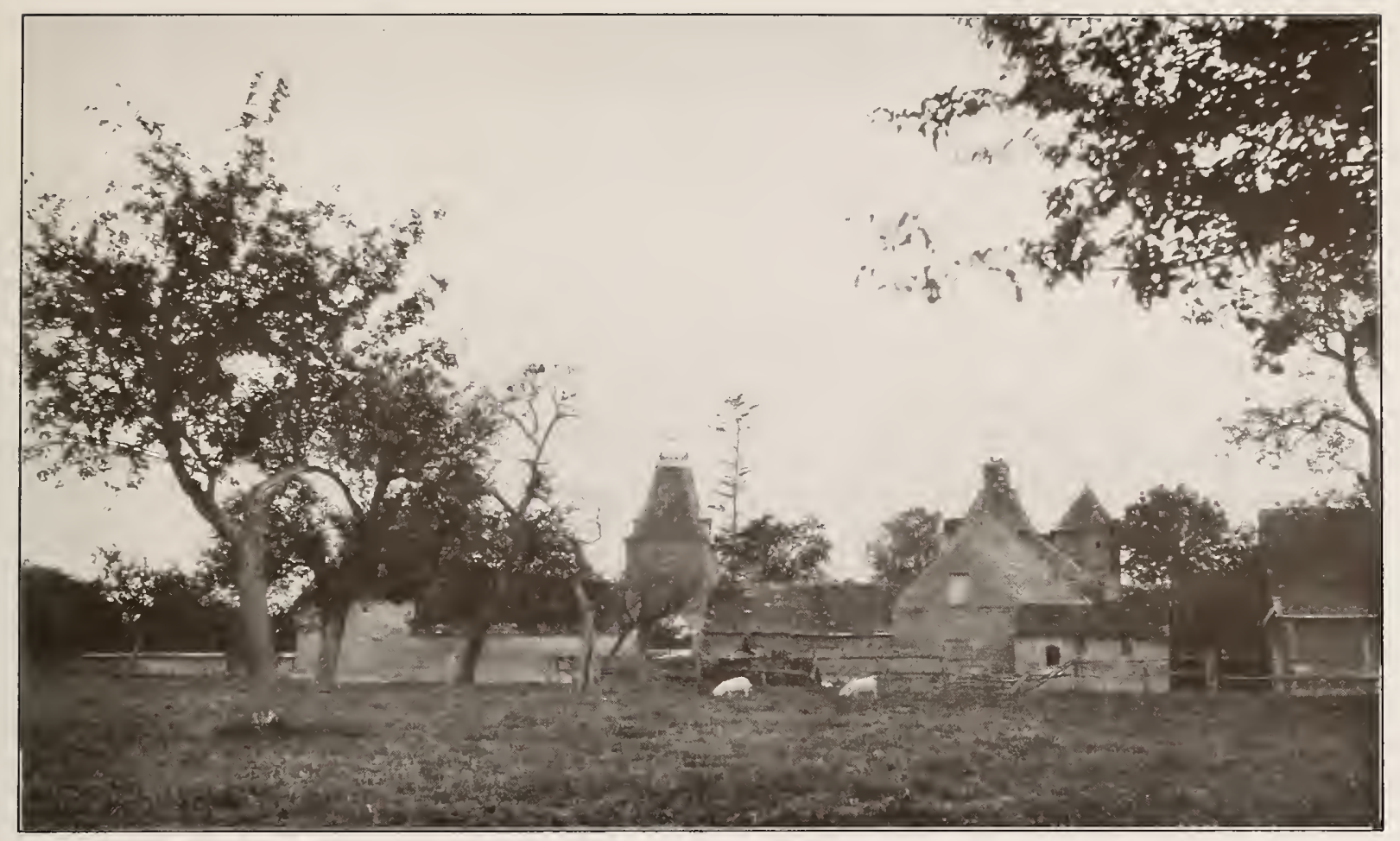

Plate 95. Farm group near Neufchâtel, Seine-Inférieure

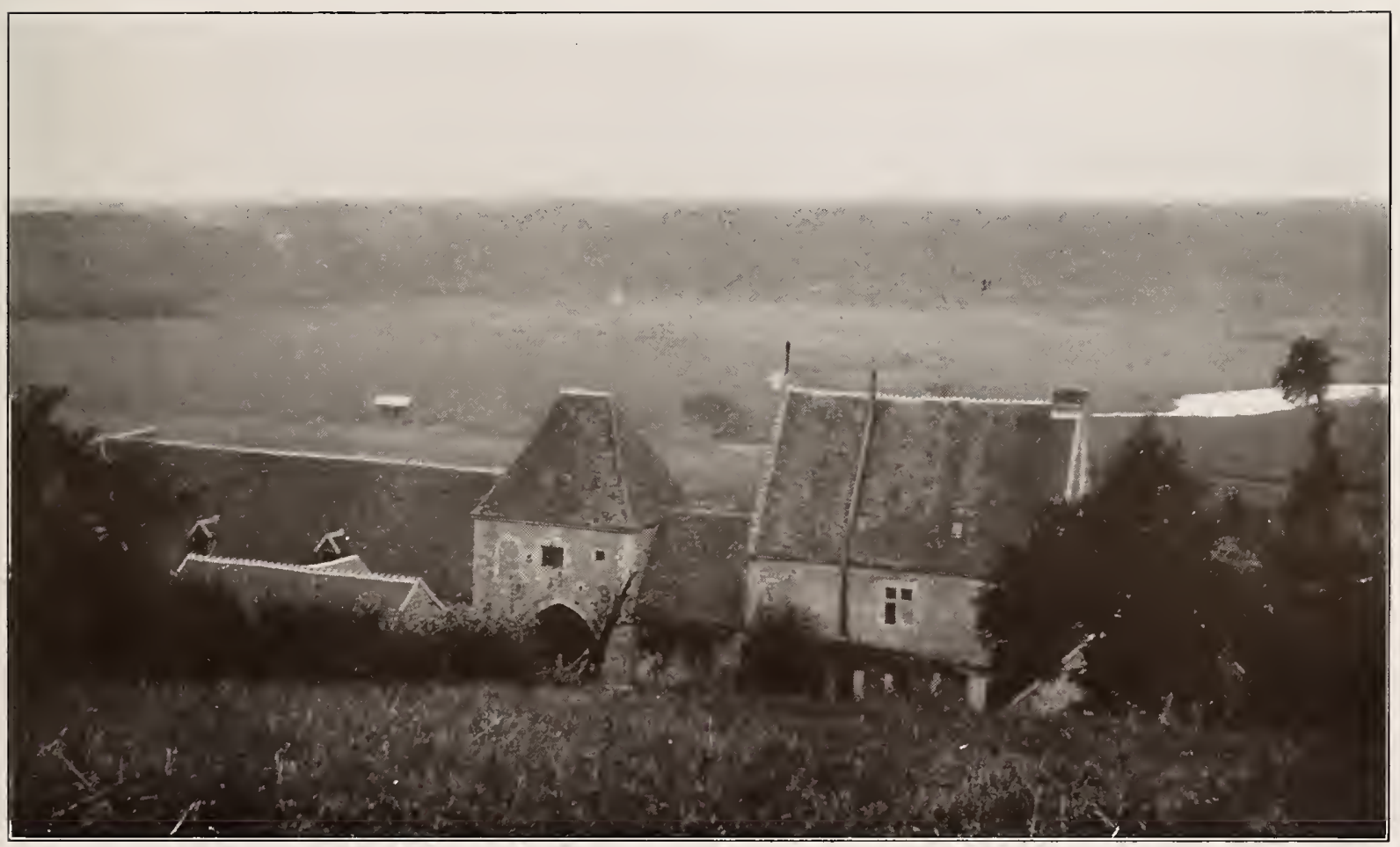

Puate 96. Horse farm near Nogent-le-Rotrou, Eure-et-Loir 



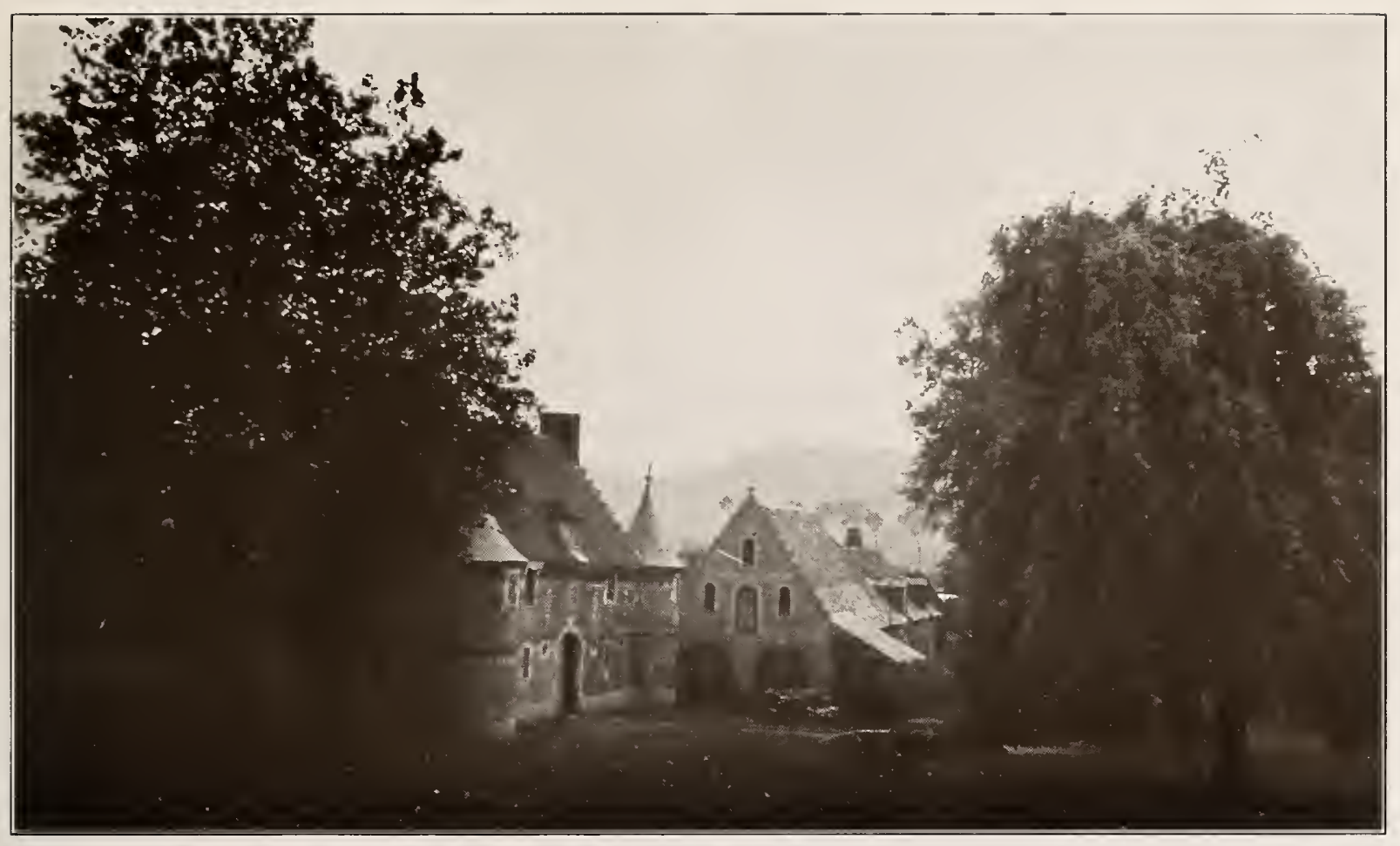

Plate 97. Manor stables at Arques-la-Bataille, Seine-Inférieure

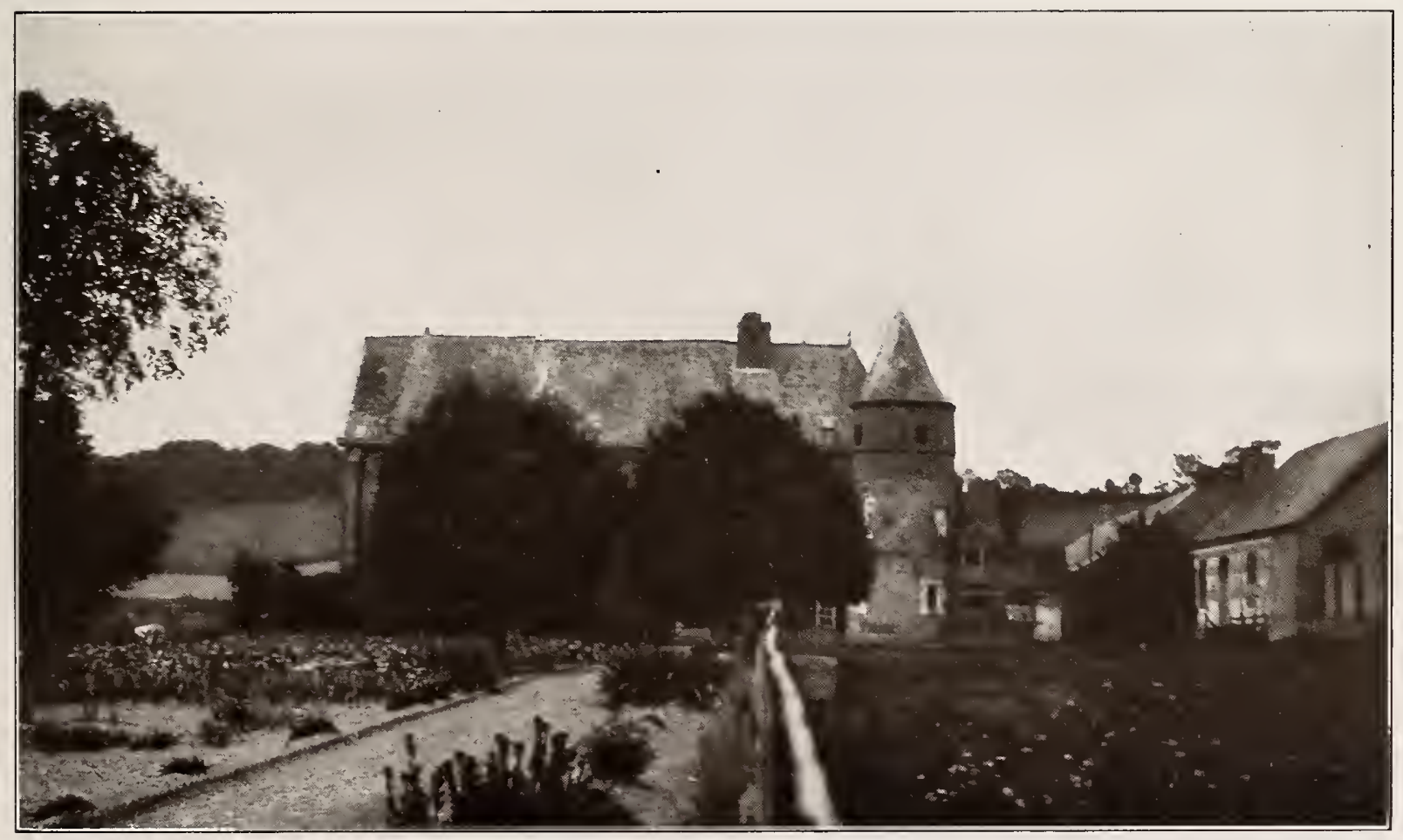

Plate 98. Manor at Esclarelles, Seine-Inférieure 



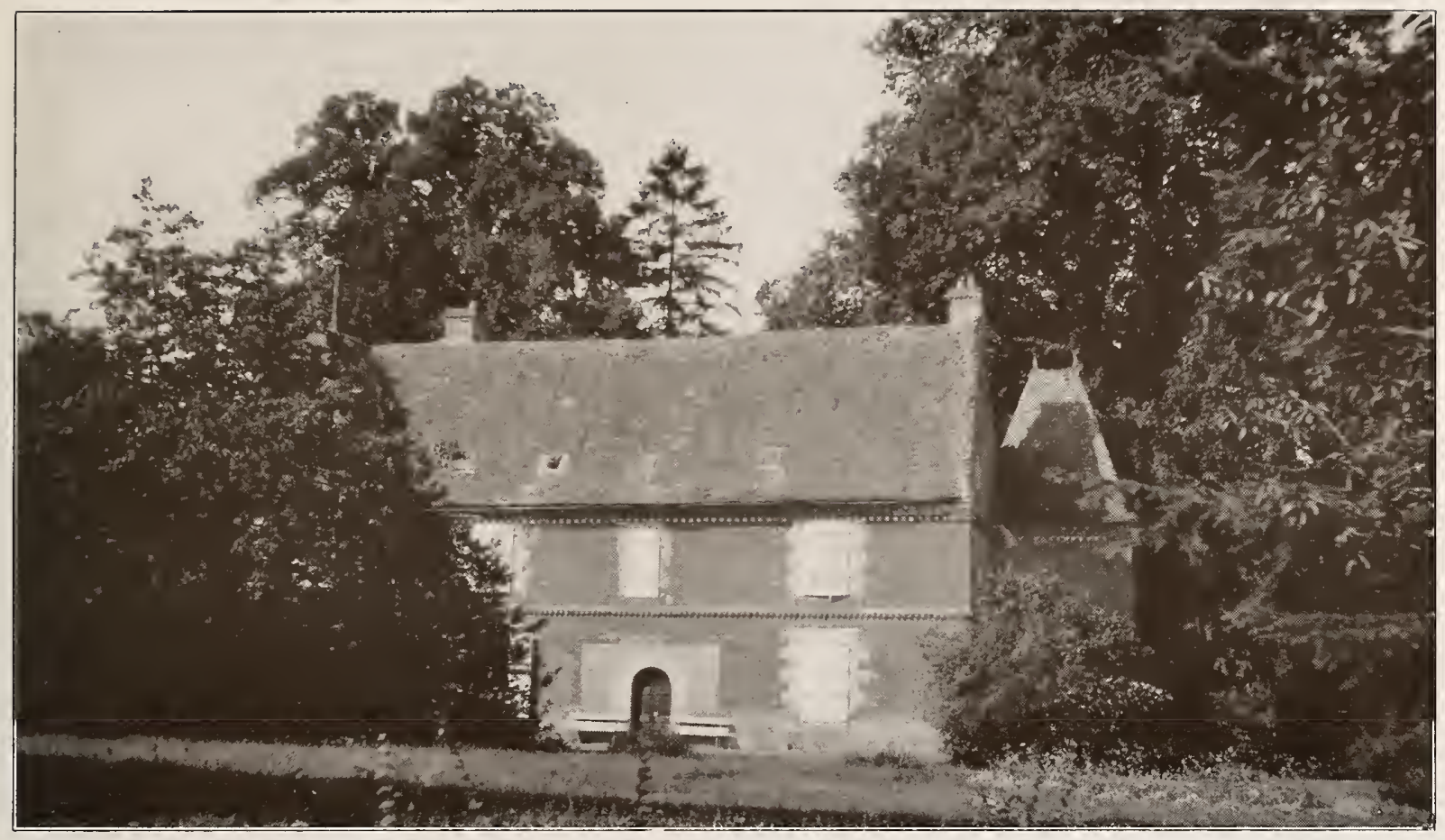

Plare 99. Manor at Croixdalle, Seine-Inférieure

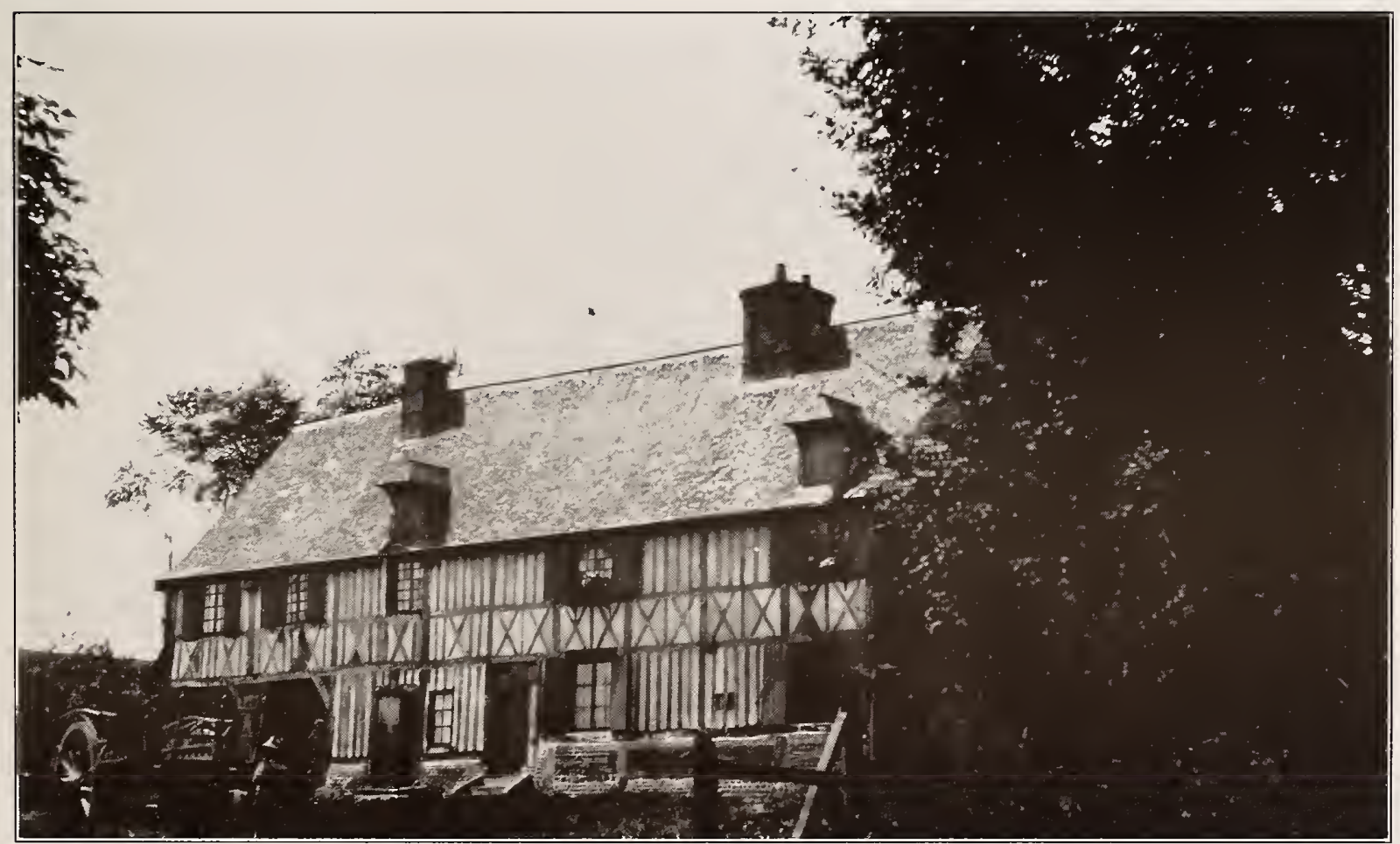

Plate ıoo. Inn near Bourdamville, Seine-Inférieure 



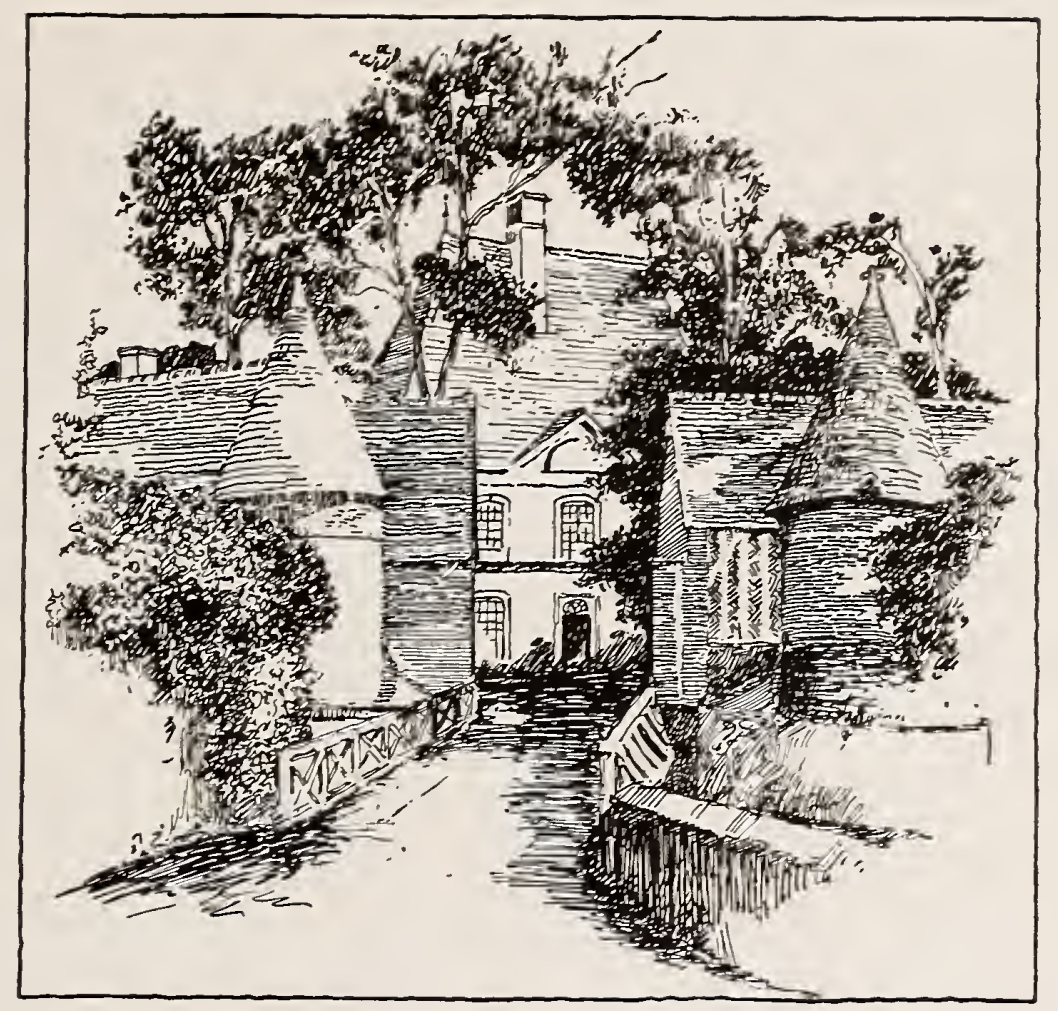

Plate roi. Château de Bémécourt, Eure

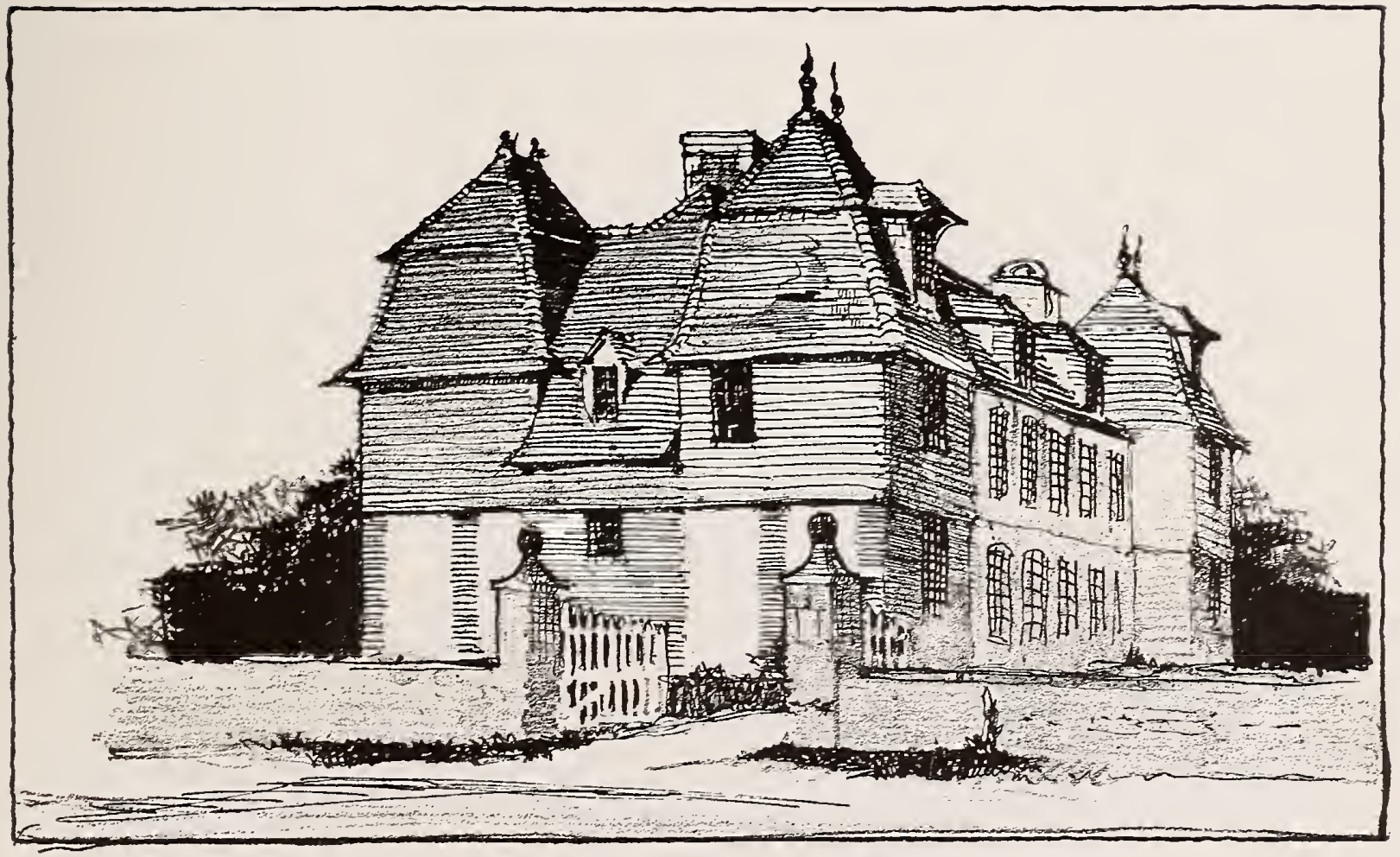

Plate 102. Sixteenth-century manor, Monteille, Calvados 



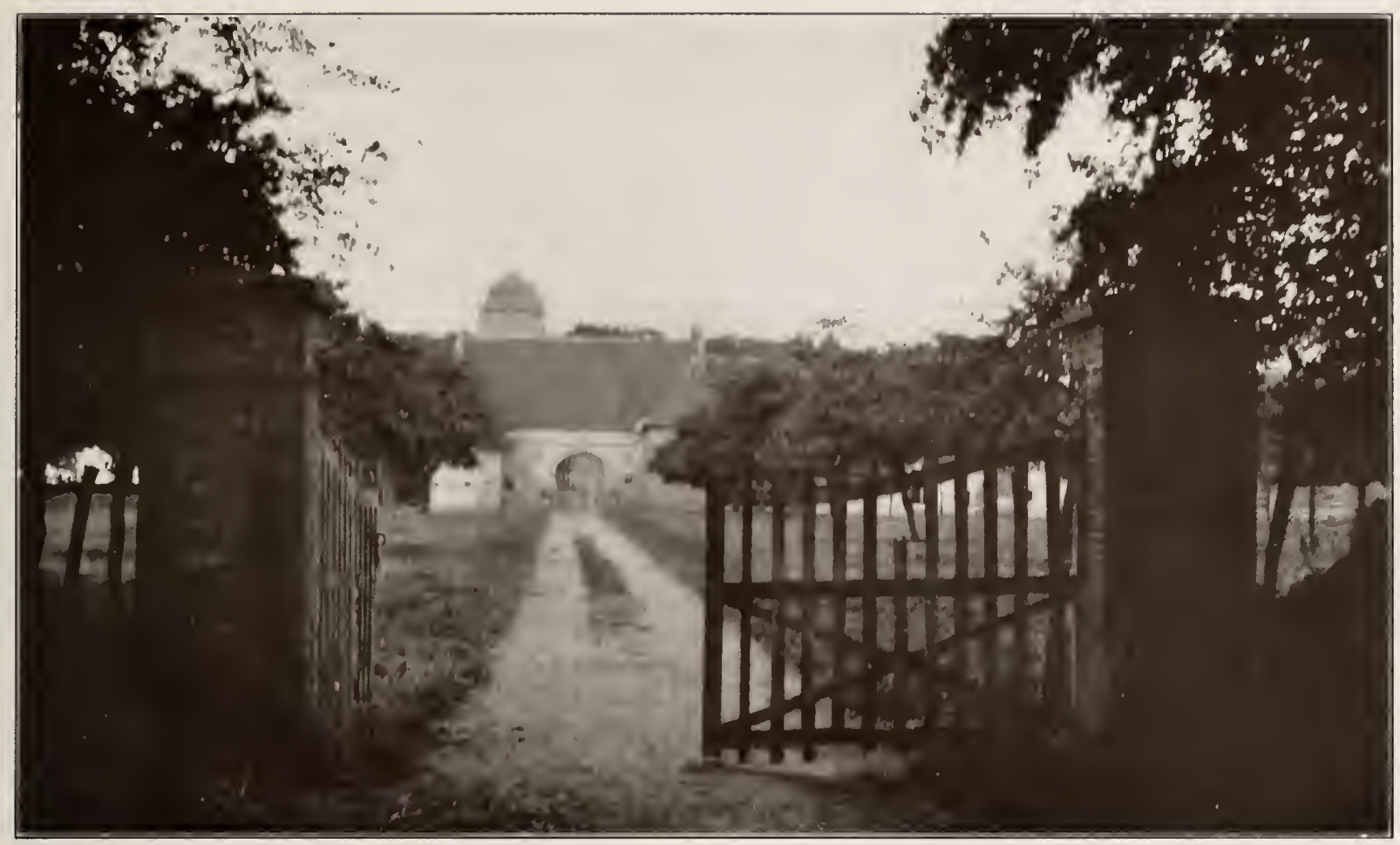

Plate 103. Gateway, Manoir d'Ango, Varengeville, Seine-Inférieure

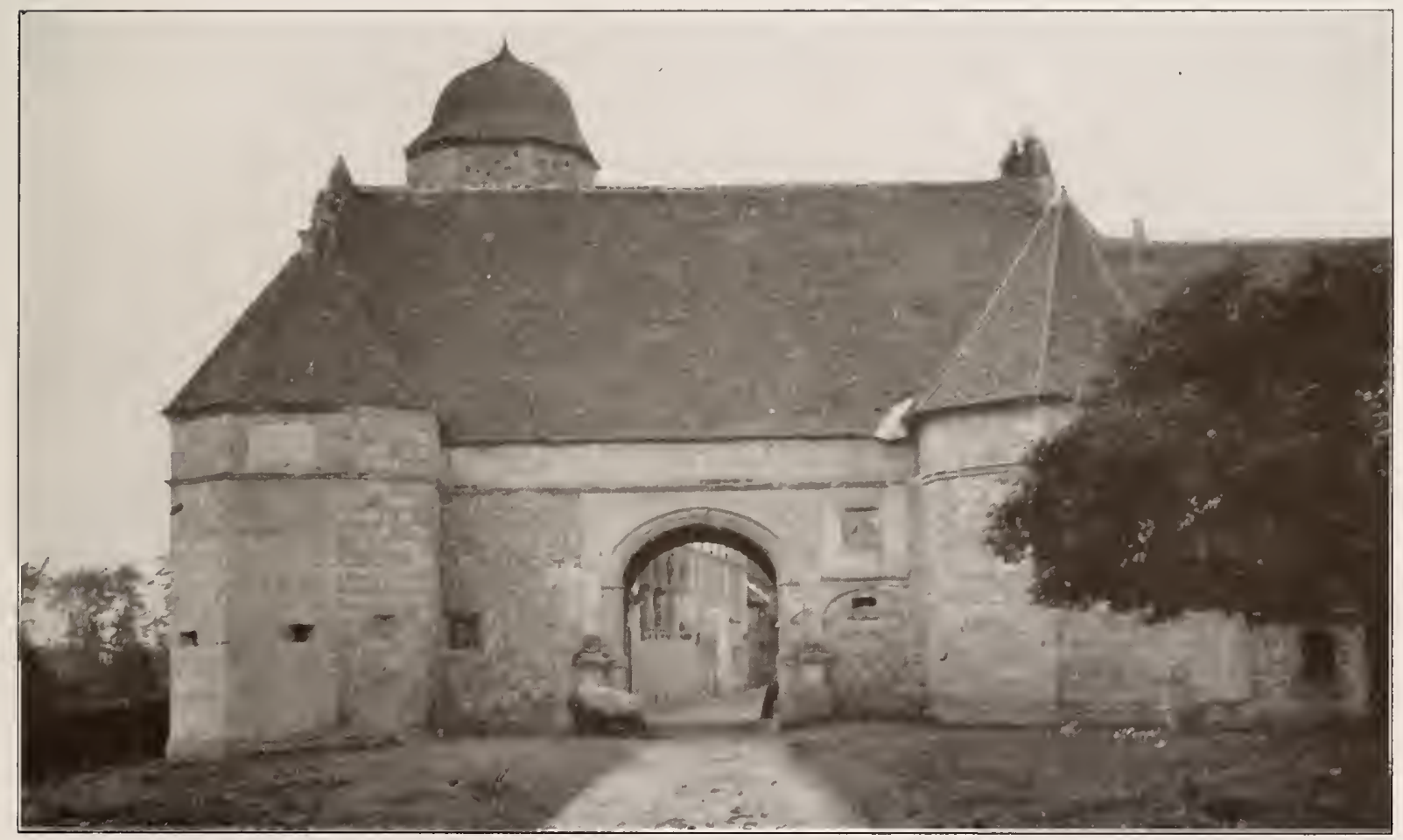

Plate ro4. Entrance to courtyard, Manoir d'Ango, Varengeville, Seine-Inférieure 



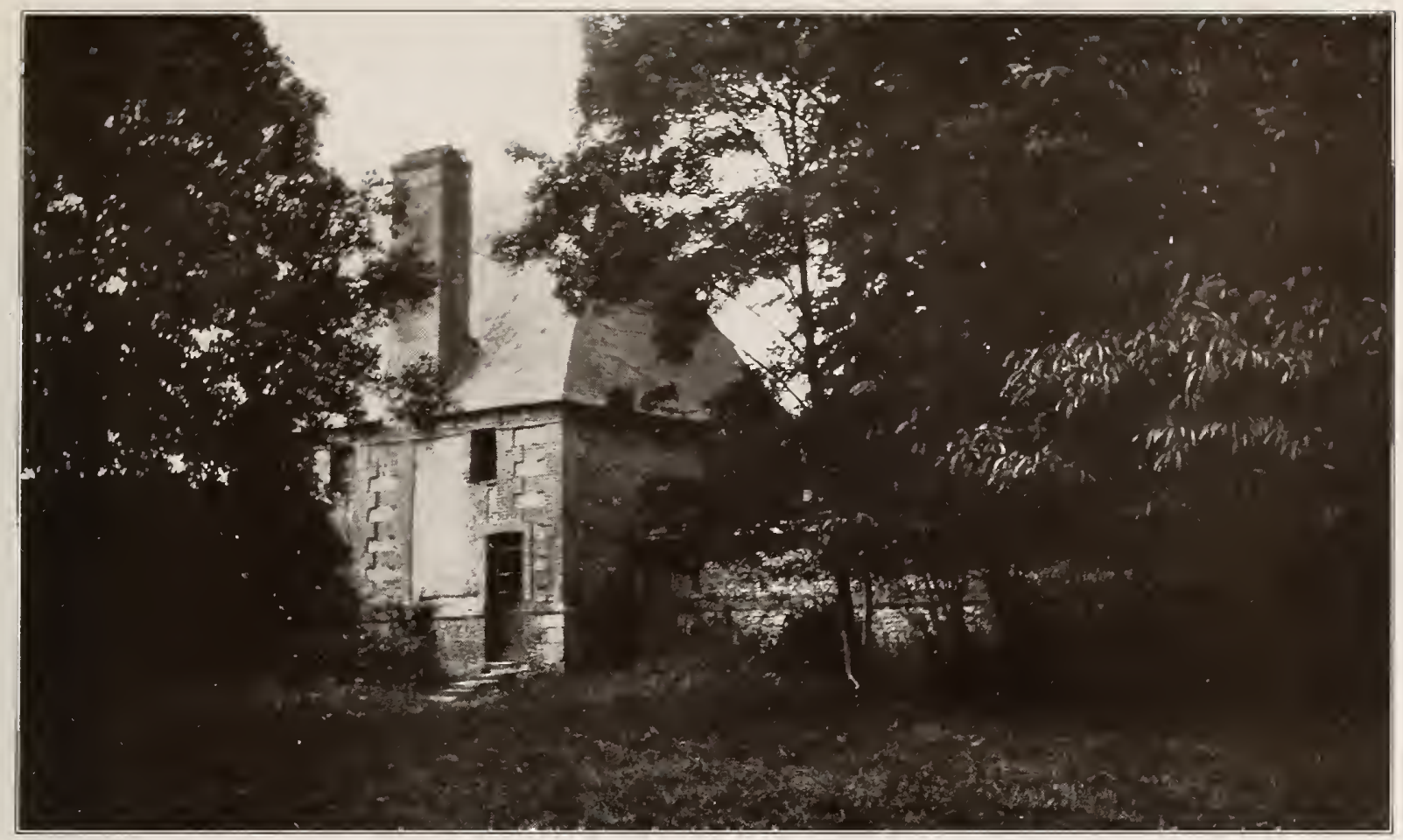

Plate 105. Farmhouse near Yerville, Seine-Inférieure

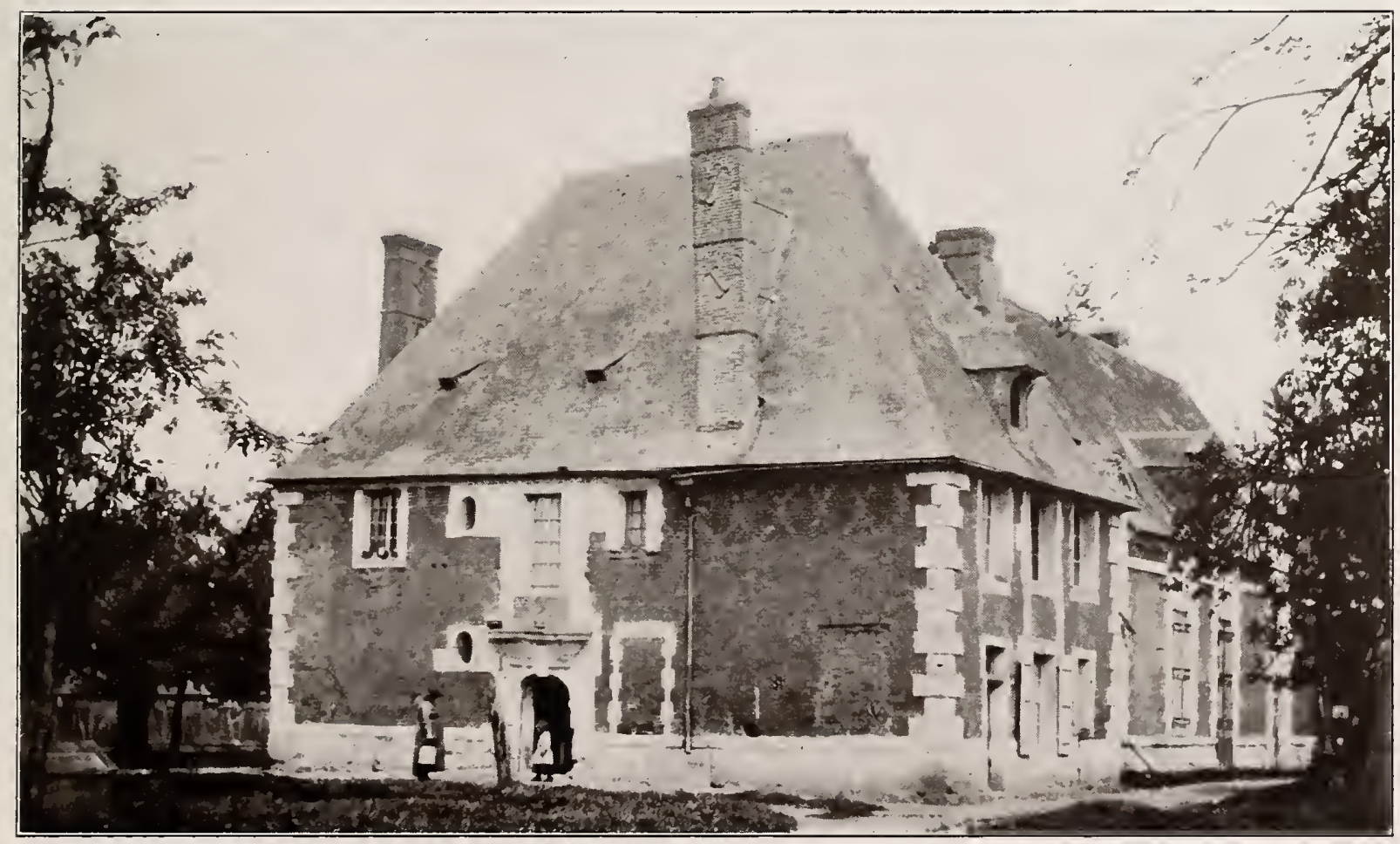

Plate ro6. Manor near Lintot, Seine-Inférieure 



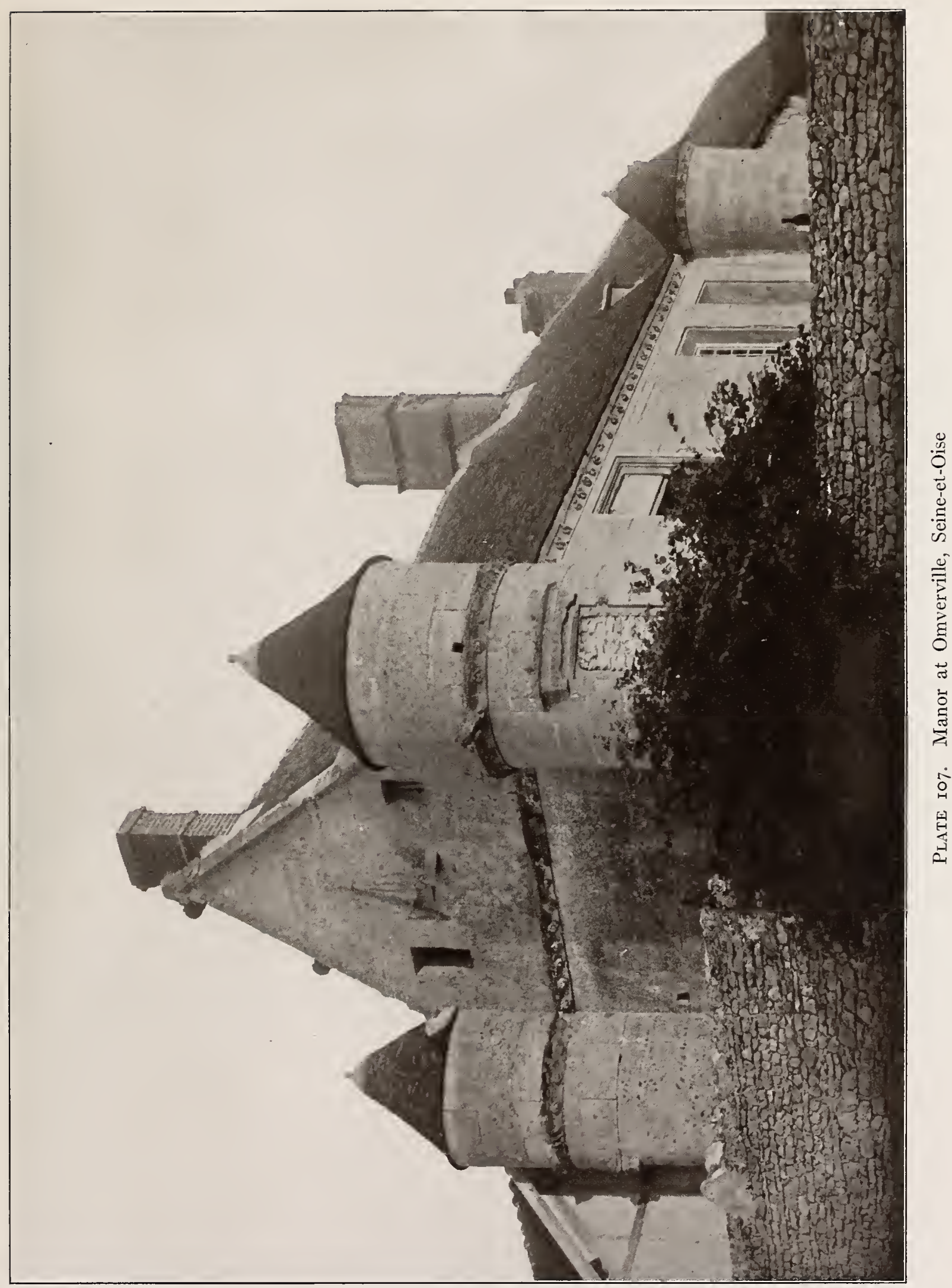





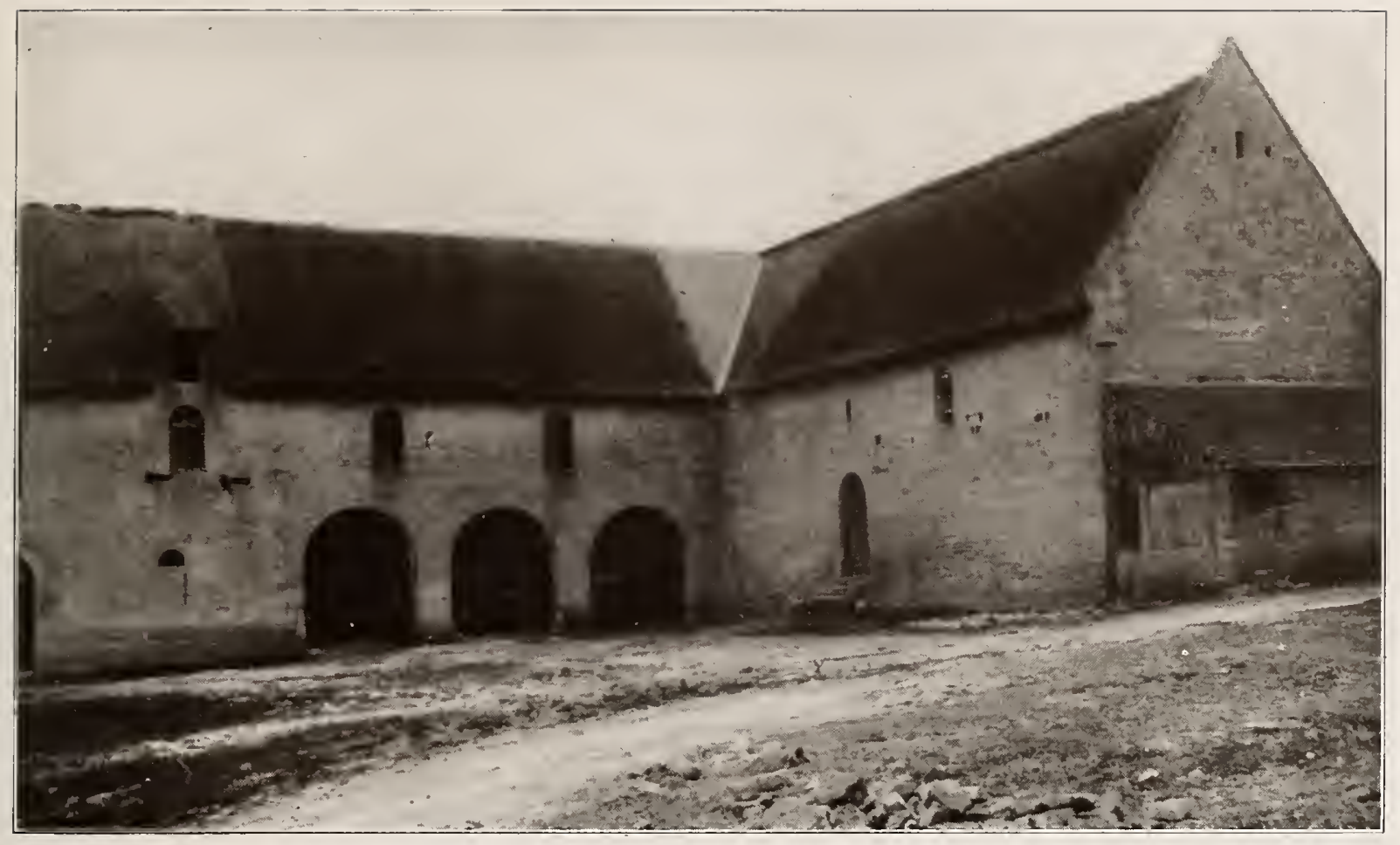

Plate io8. Stables near Brécy, Calvados

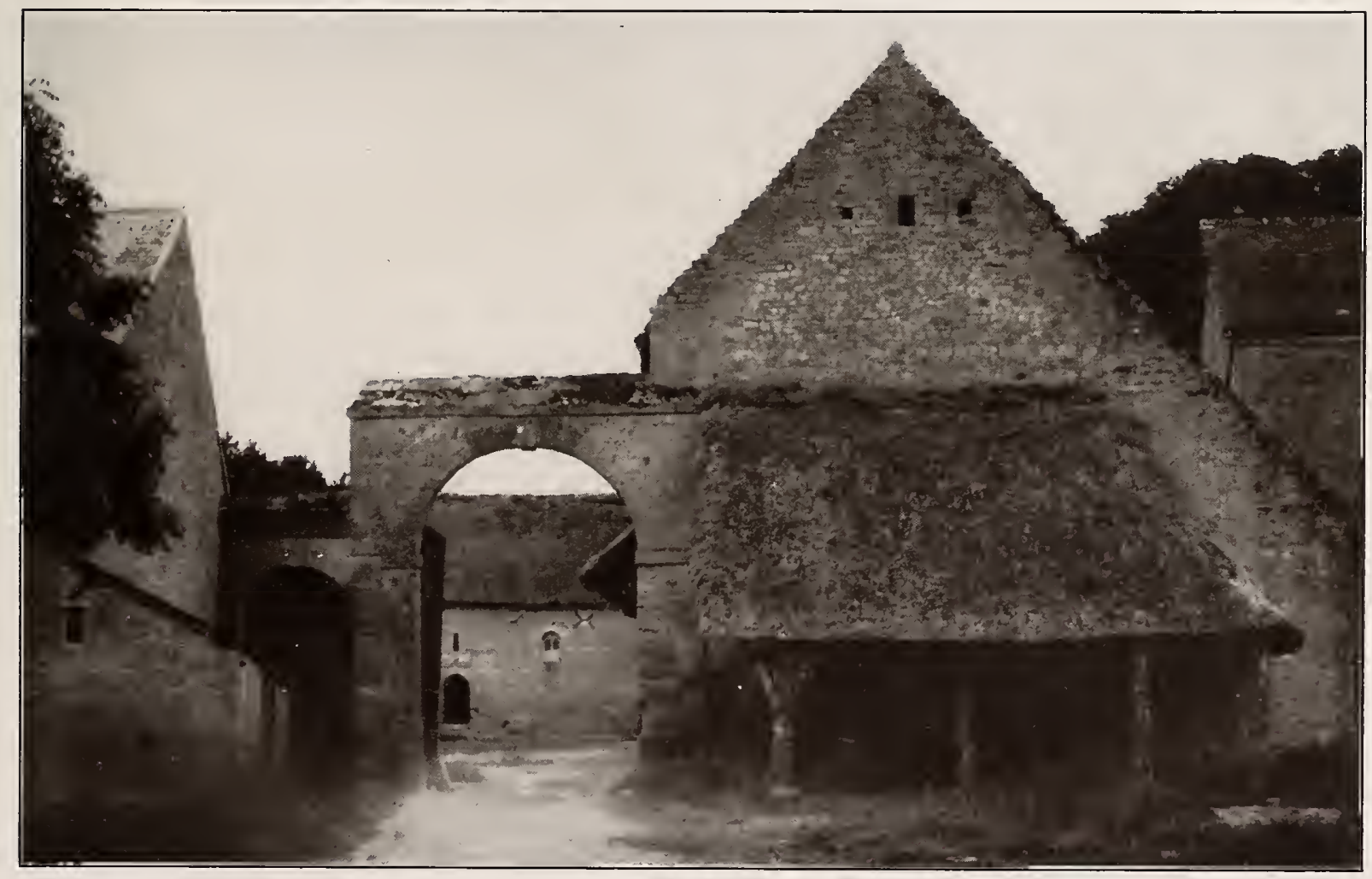

Plate iog. Farmyard near Brécy, Calvados 



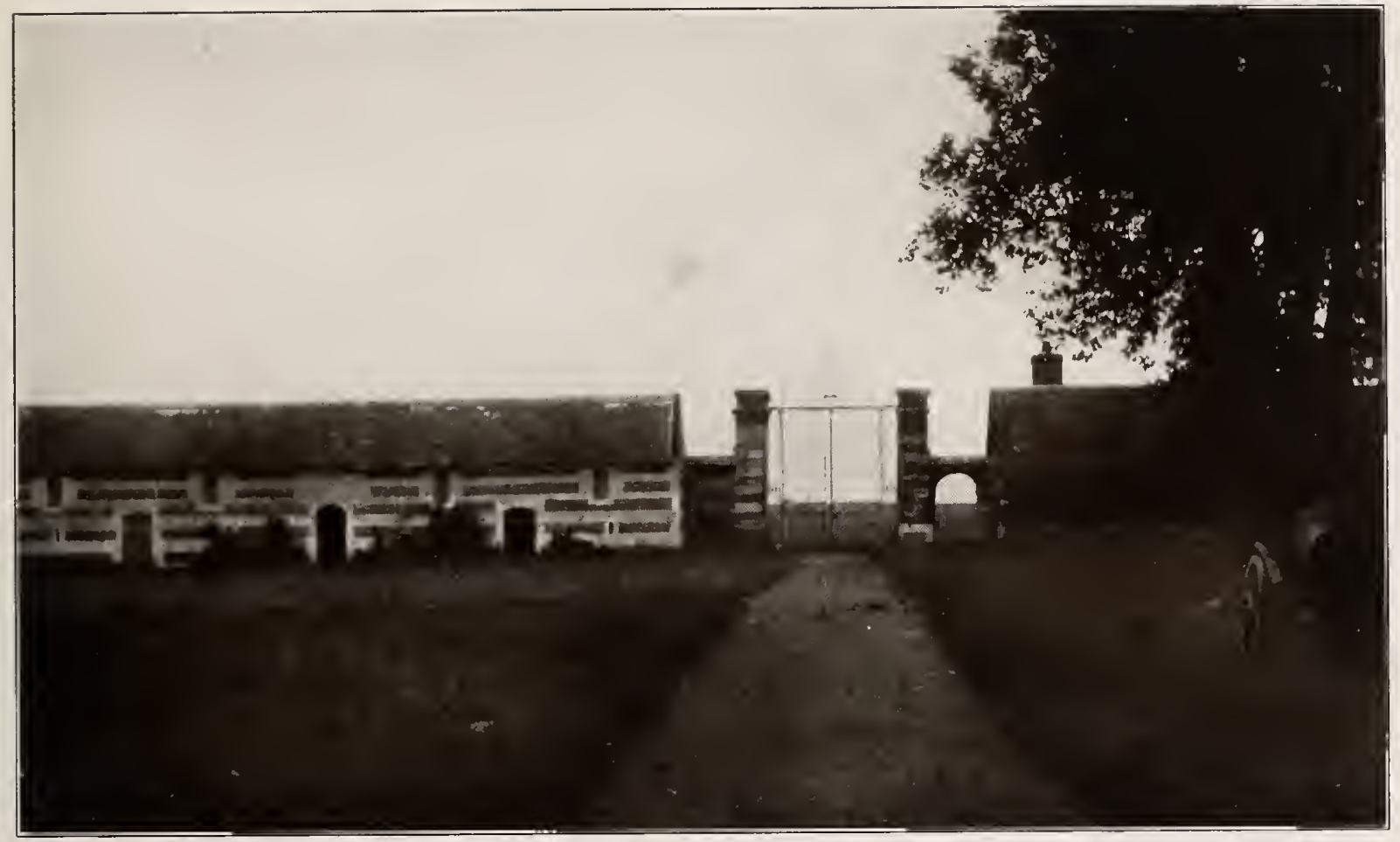

Plate i io. Farmyard, St. Jean-de-Follerville, Seine-Inférieure

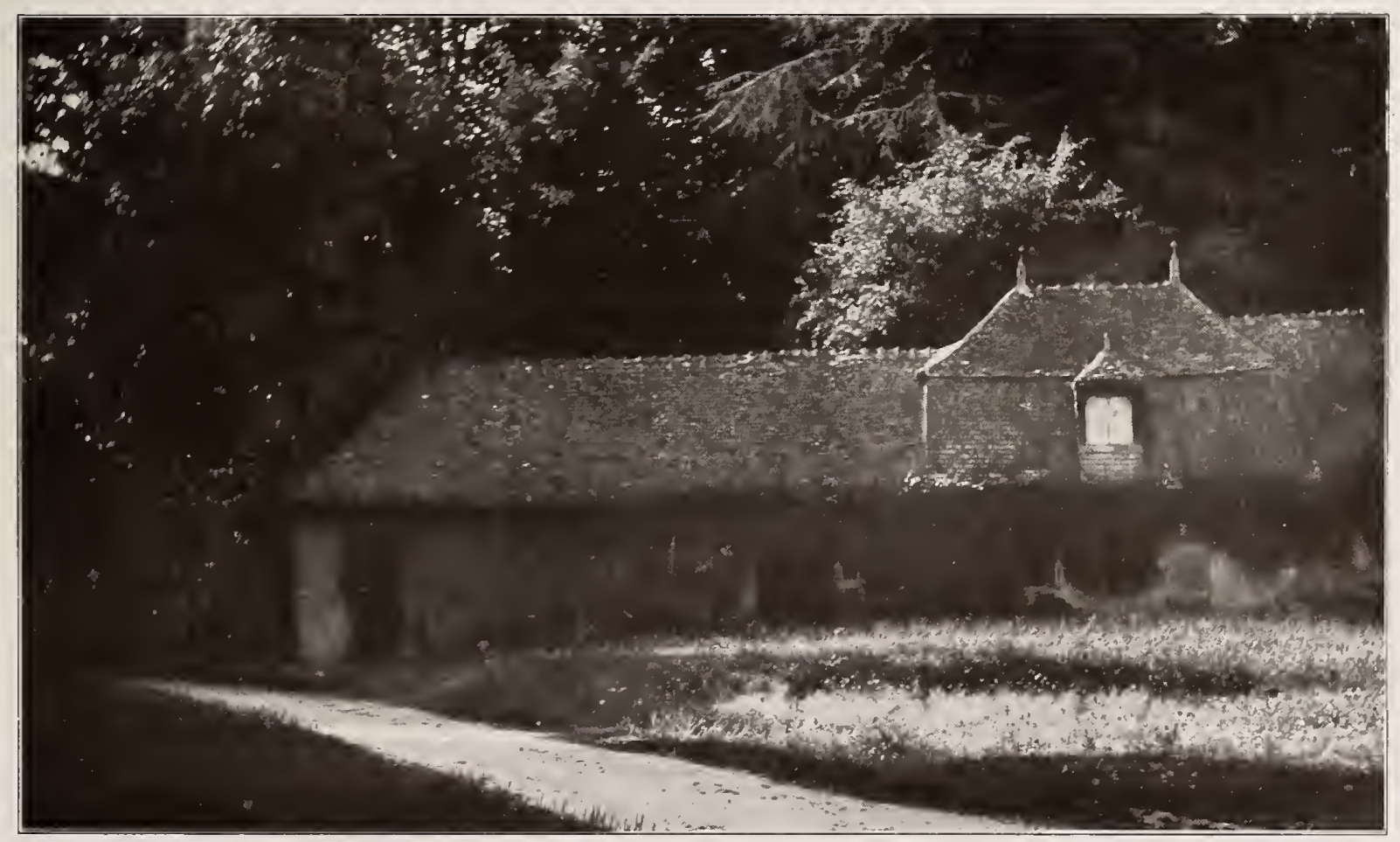

Plate ir I. Farm building near St. Léger, Saône-et-Loire 



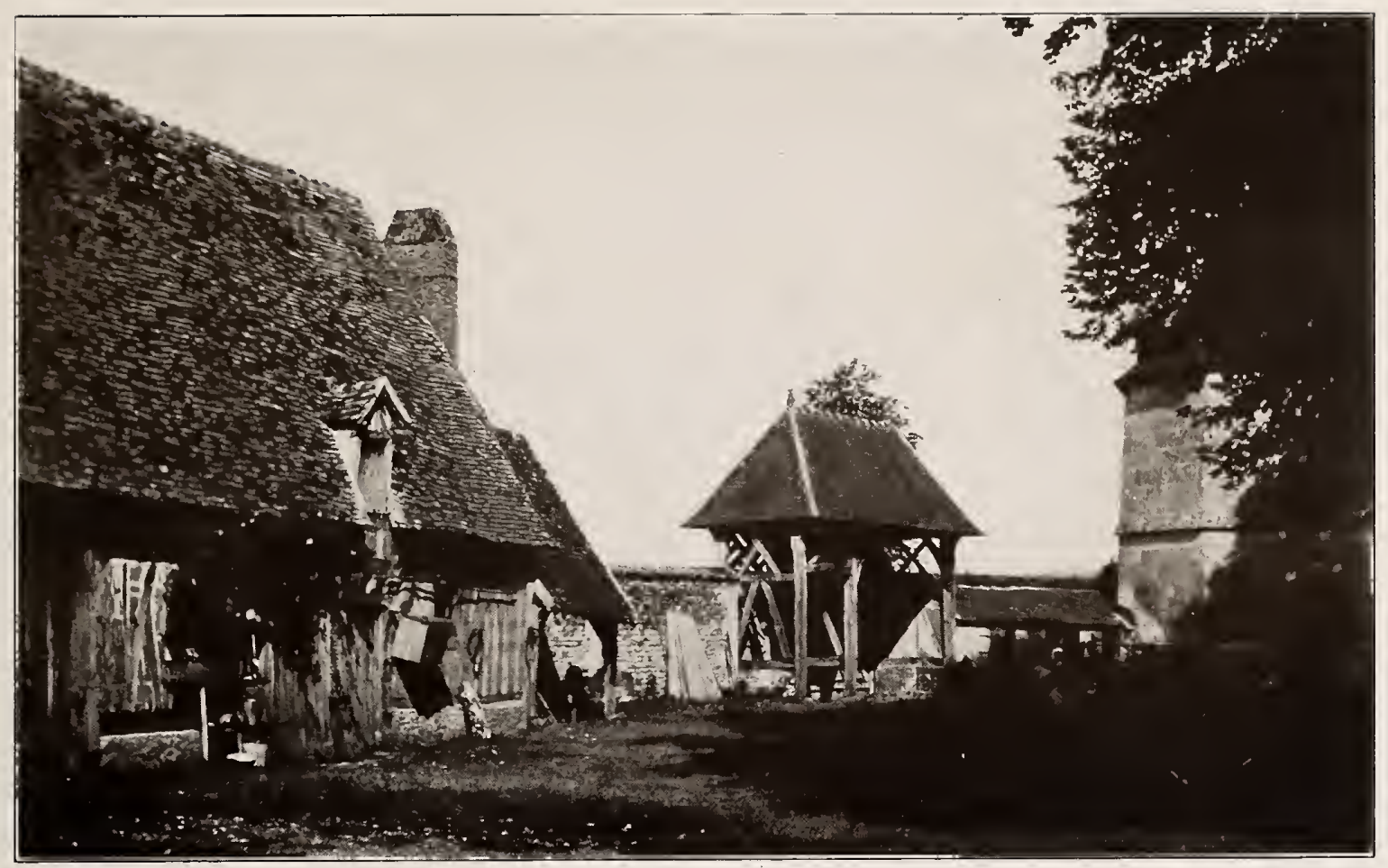

PLATE II ${ }^{`}$. Farmyard near Brézolles, Eure-et-Loir

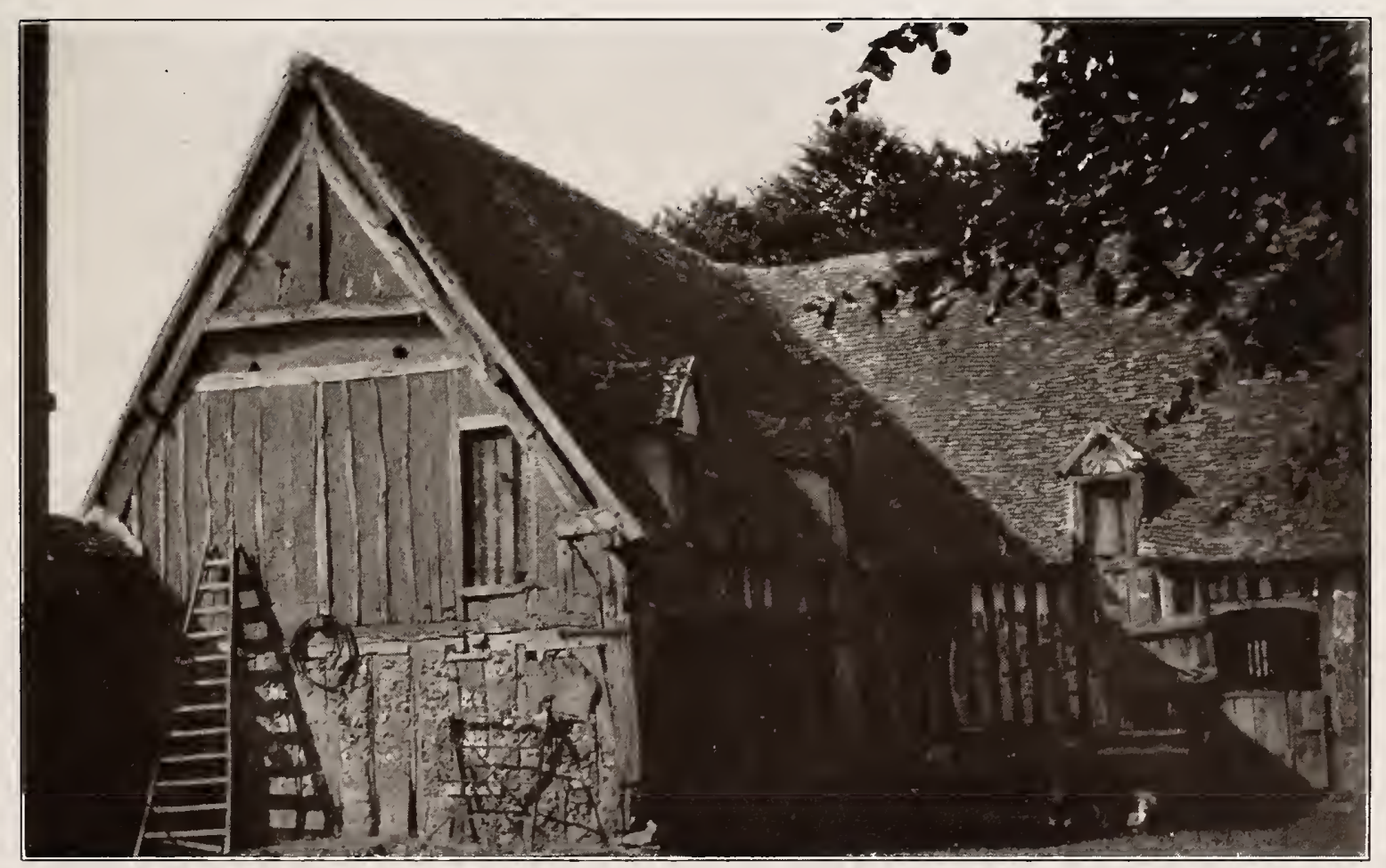

Piate I I3. Stable near Brézolles, Eure-et-Loir 



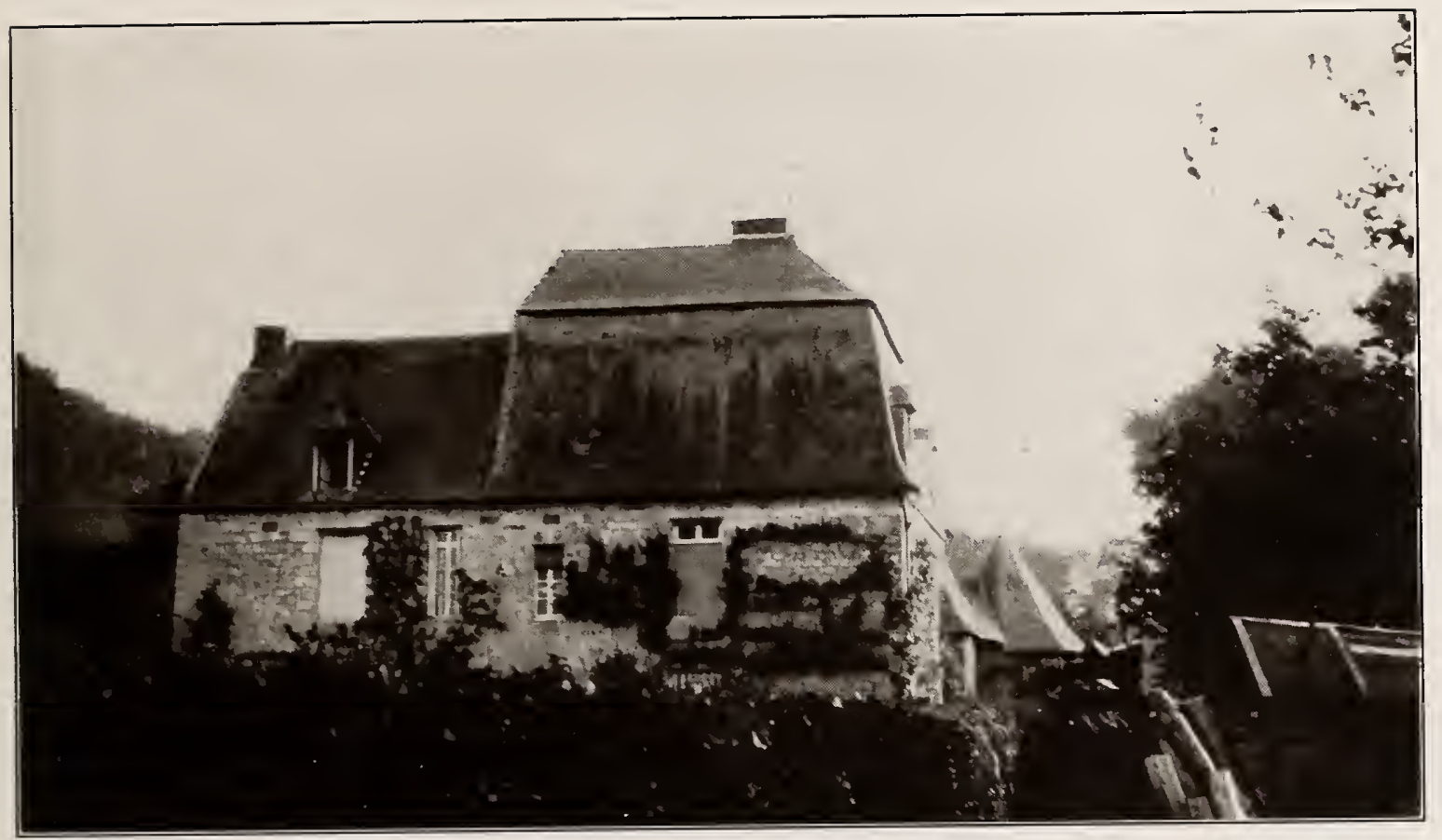

Plate I 4. Farmhouse at St. Pierre-le-Viger, Seine-Inférieure

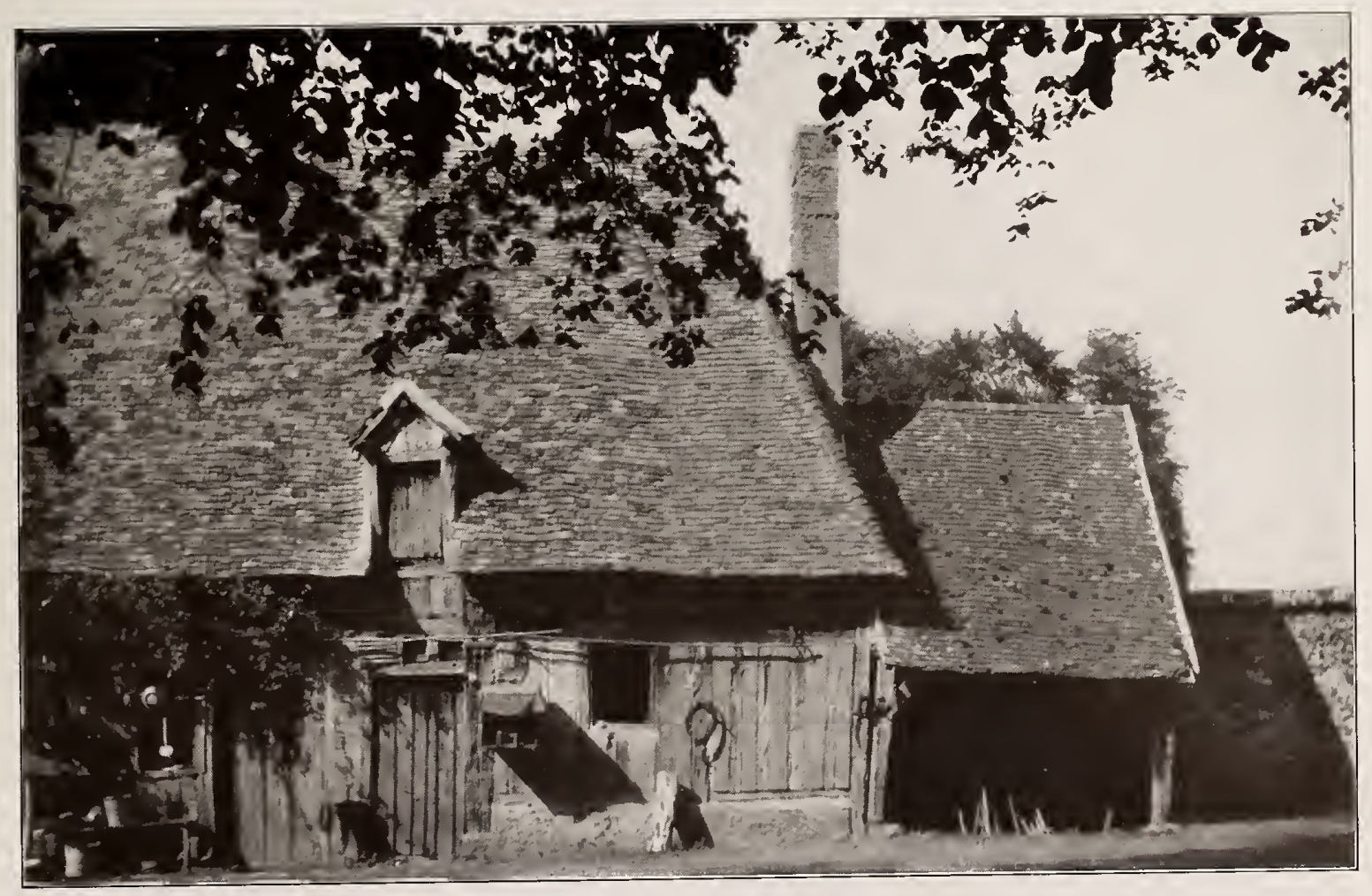

Plate II5. Farm building near Brézolles, Eure-et-Loir 



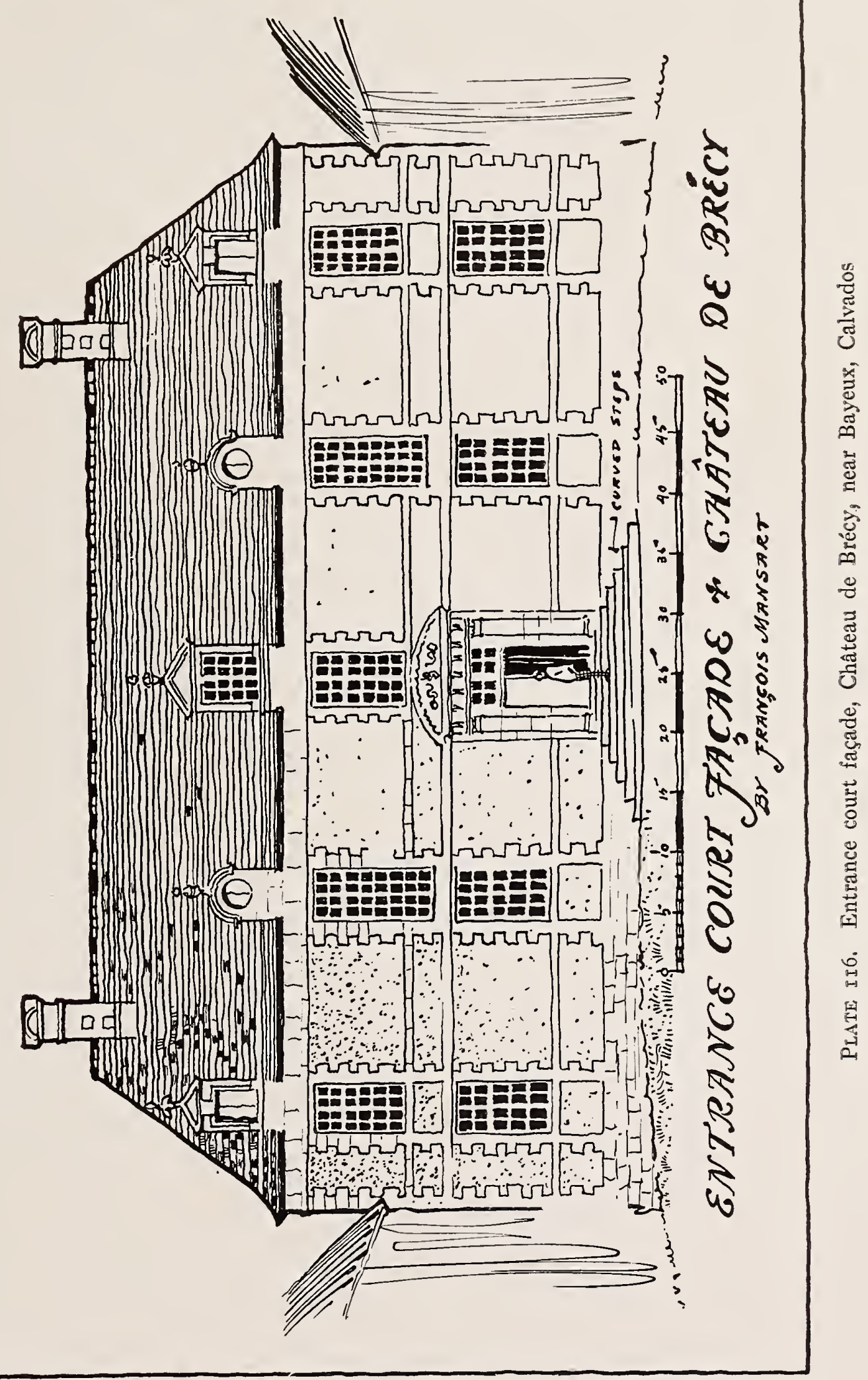





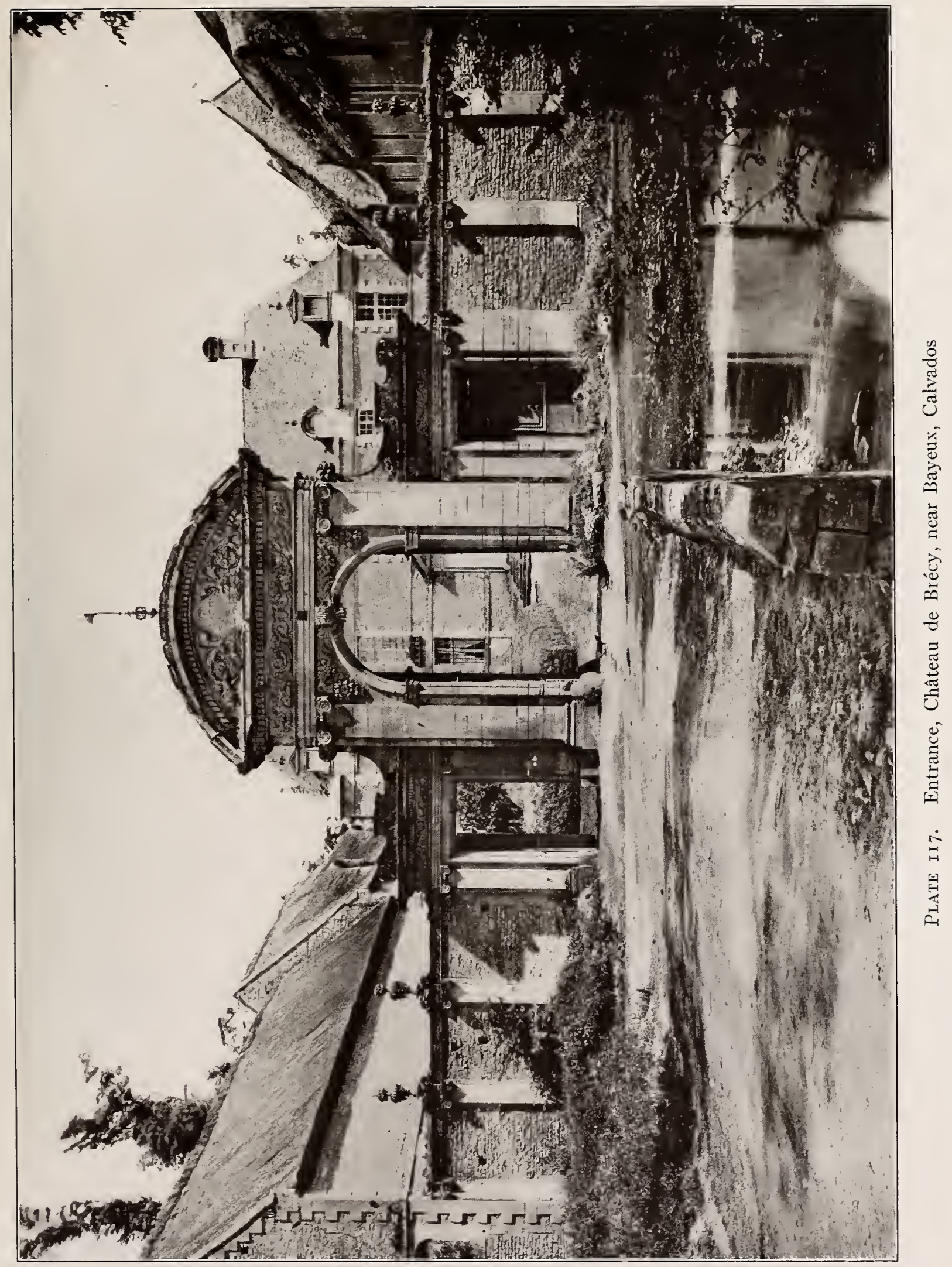





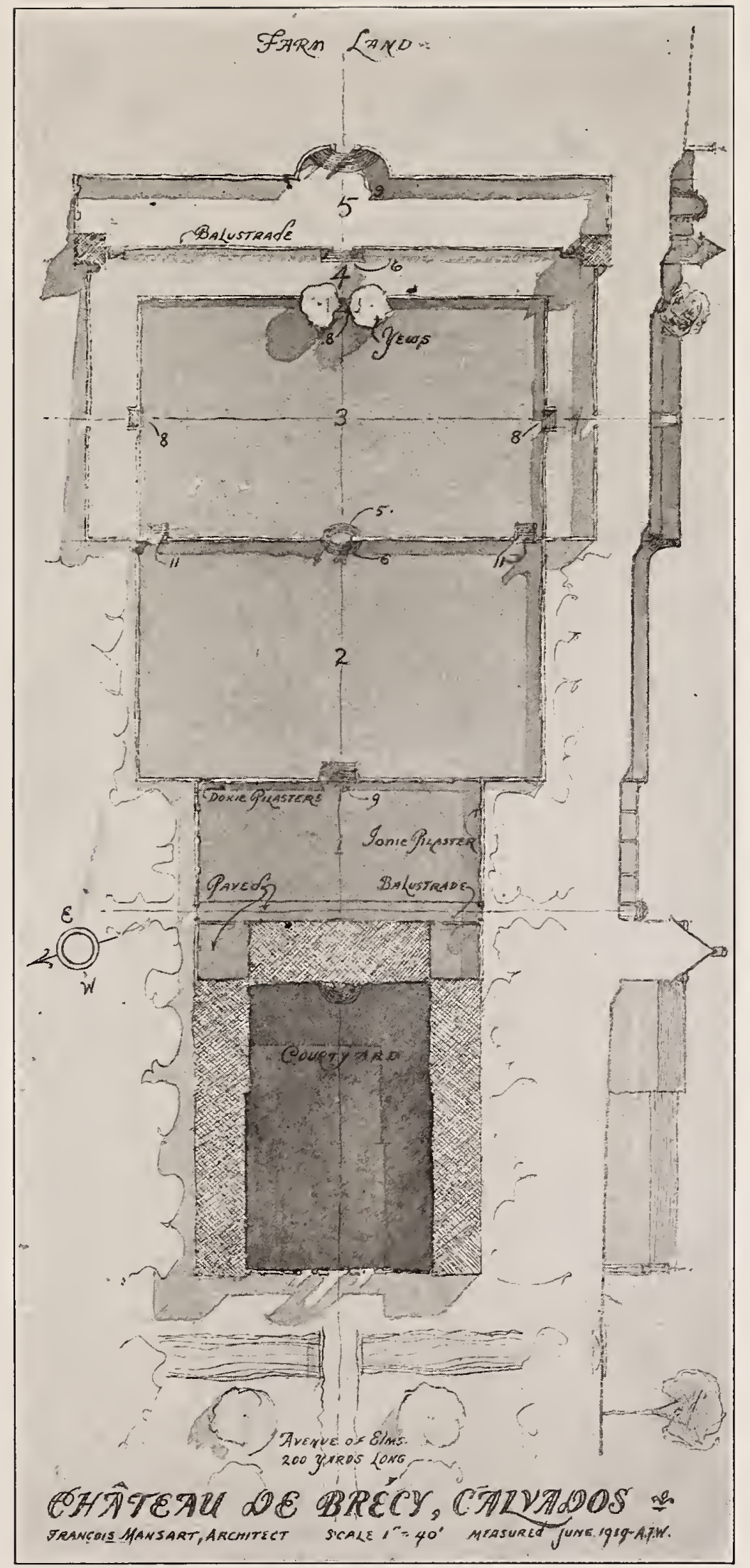

Plate ri8. General plan of Château de Brécy, near Bayeux, Calvados 



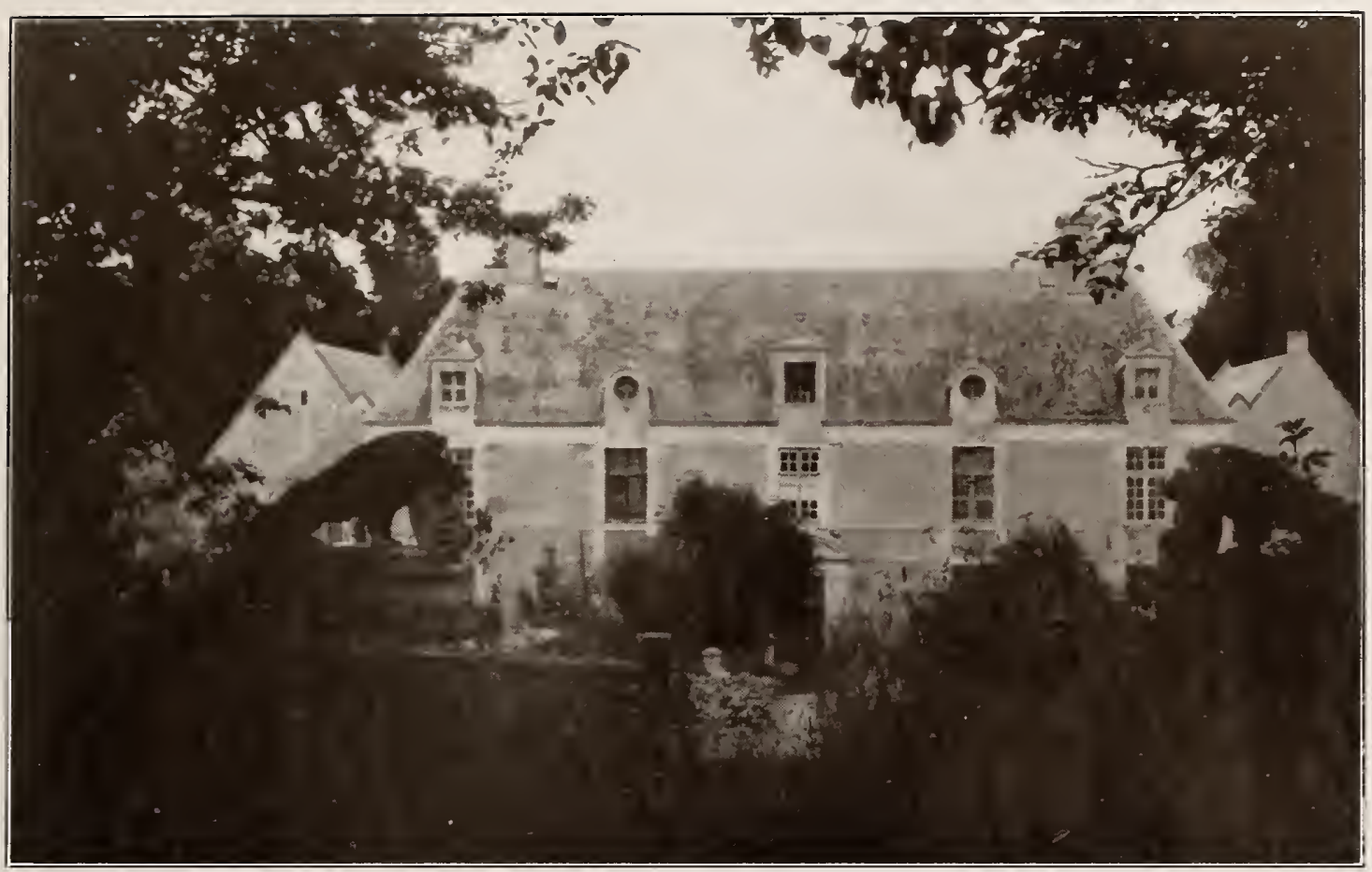

Plate irg. Château de Brécy, near Bayeux, Calvados

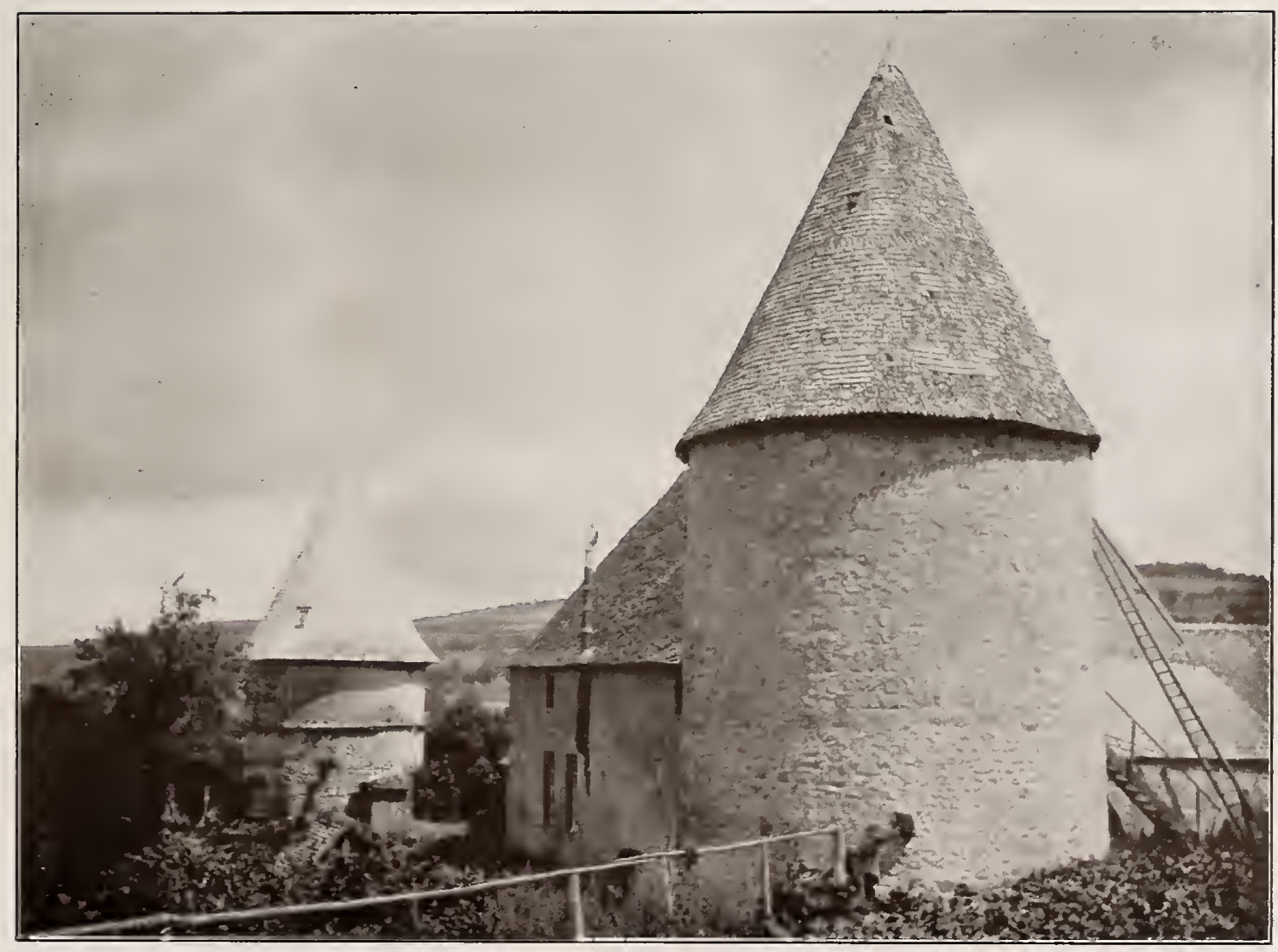

Plate i 20. Farm near St. Léger, Saône-et-Loire 



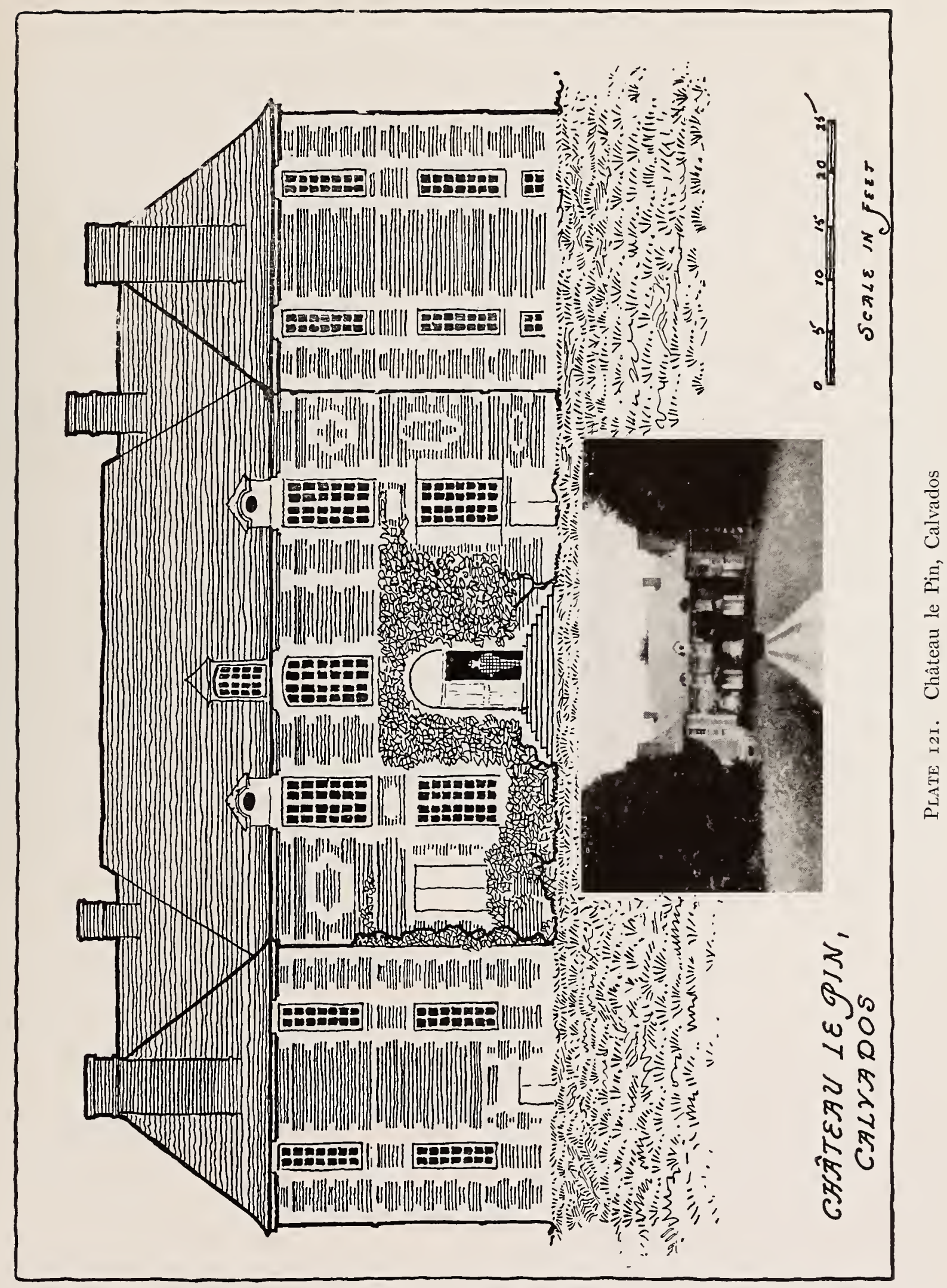





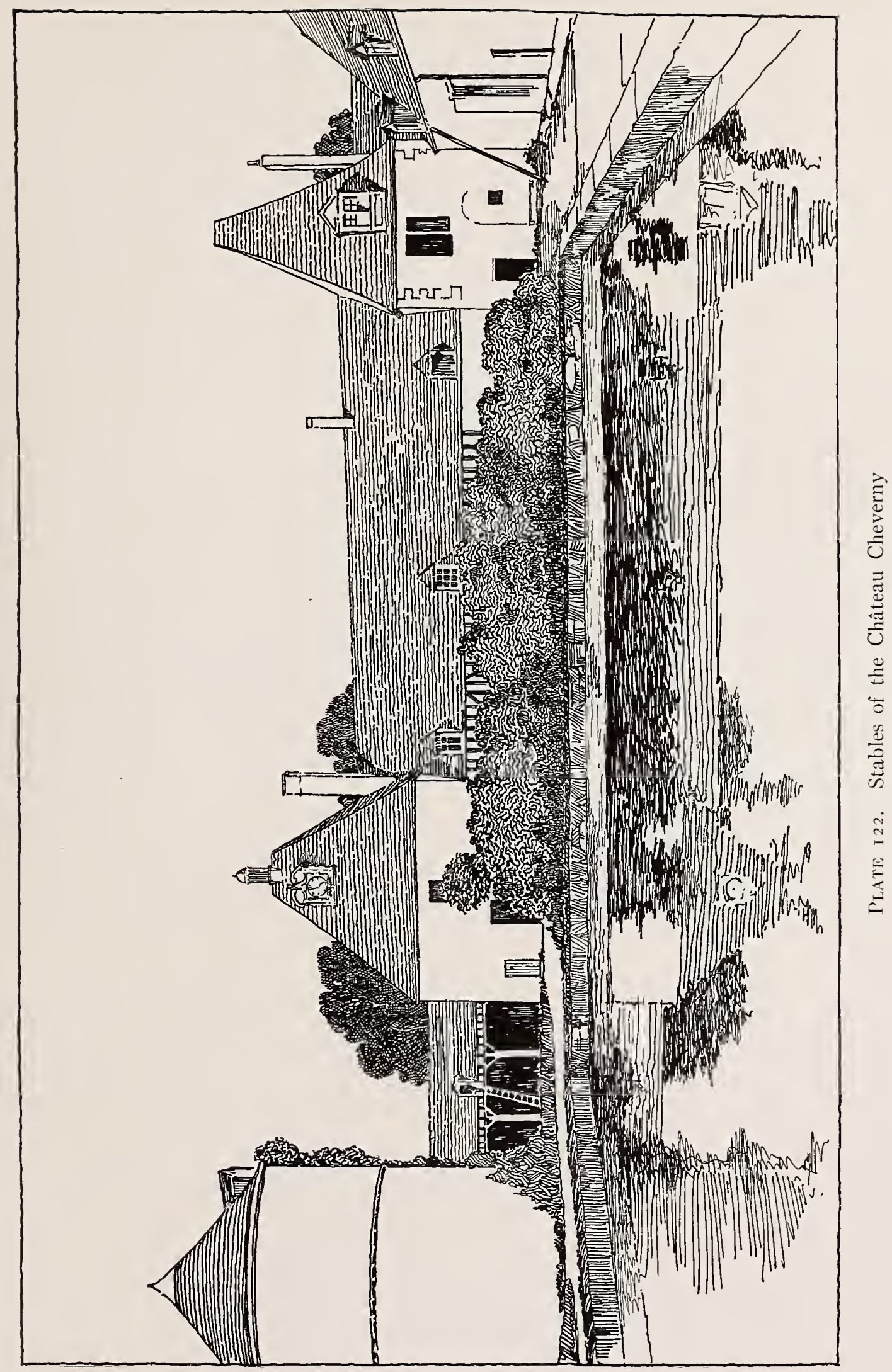





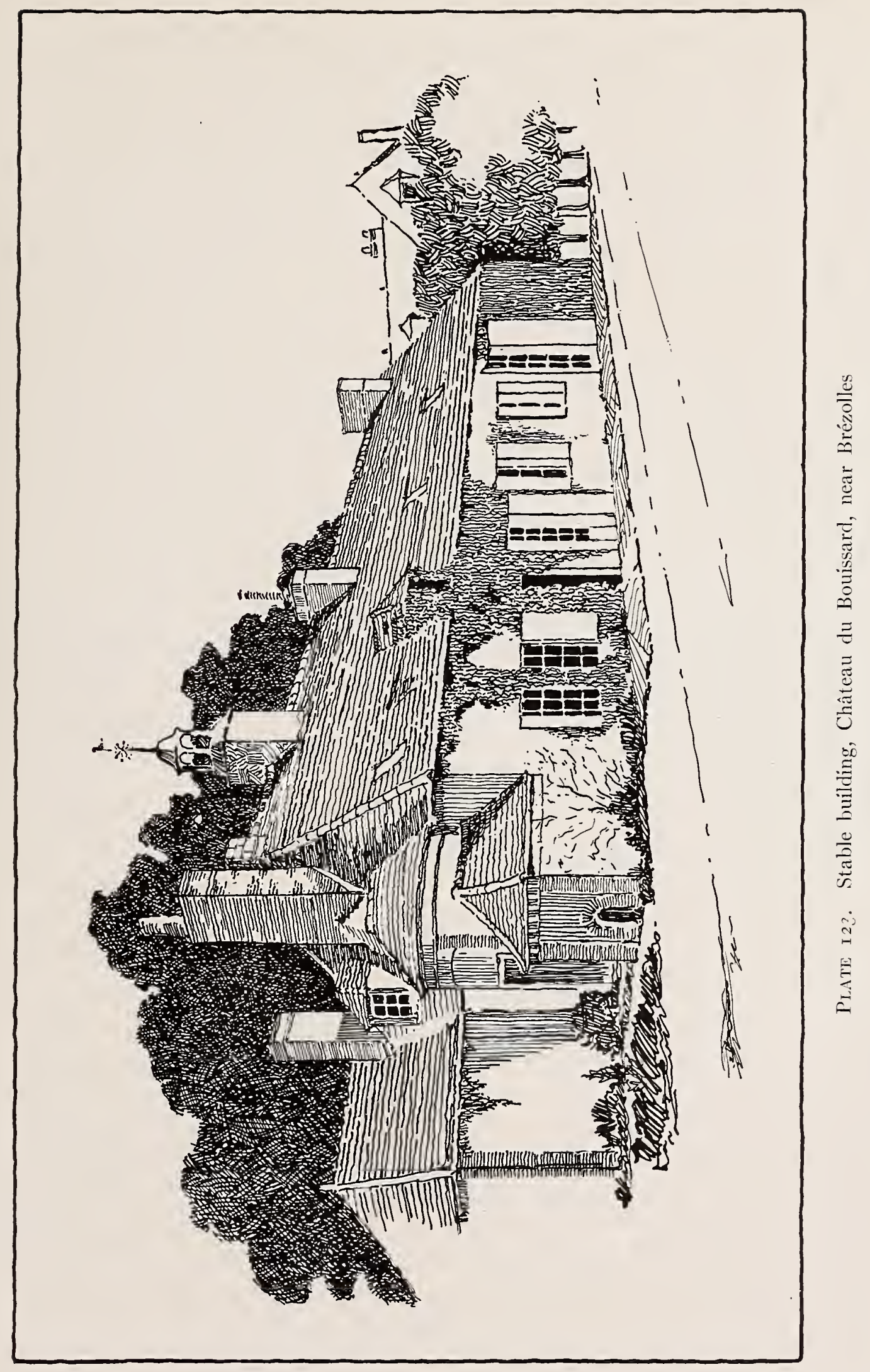





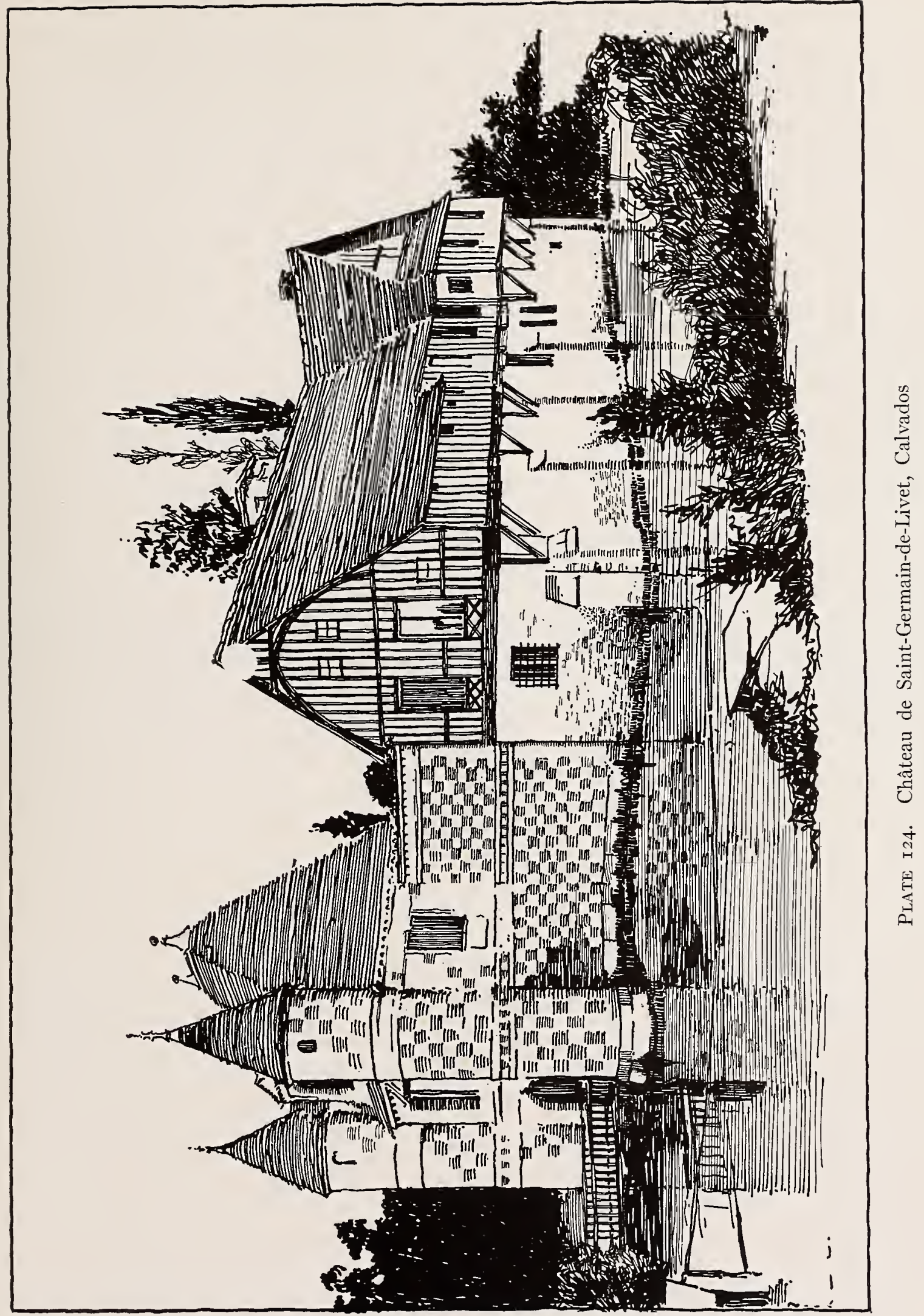





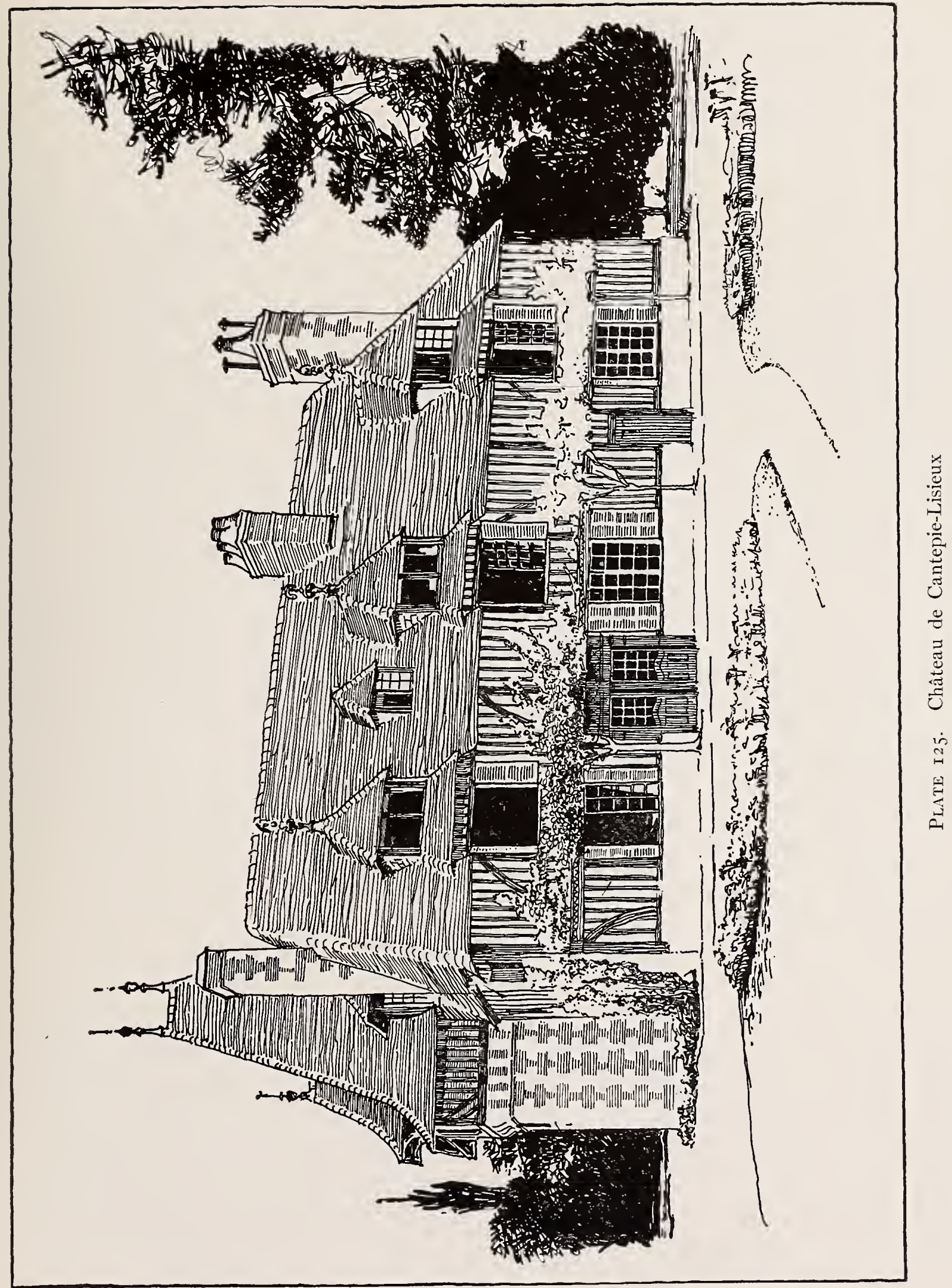



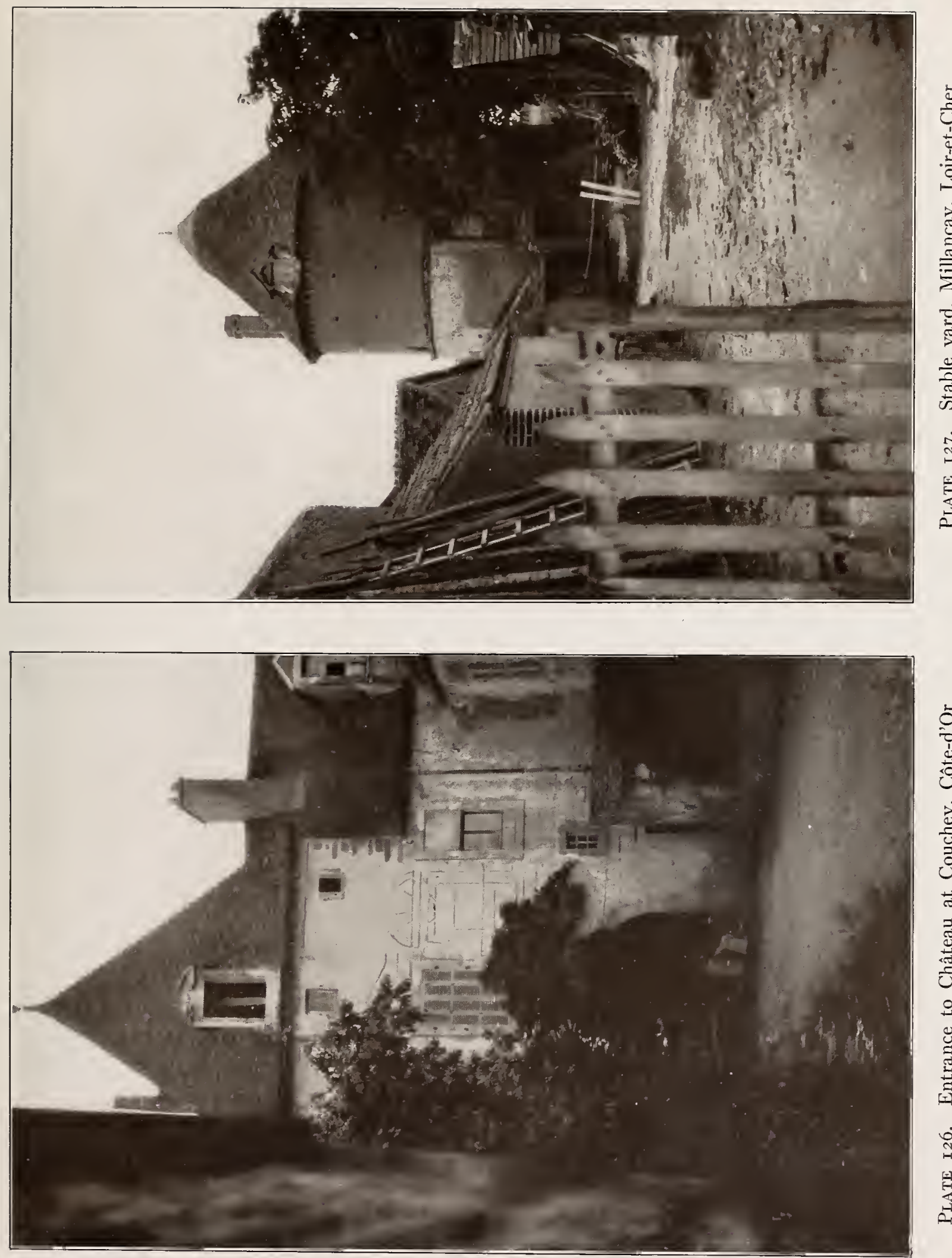

Oे 



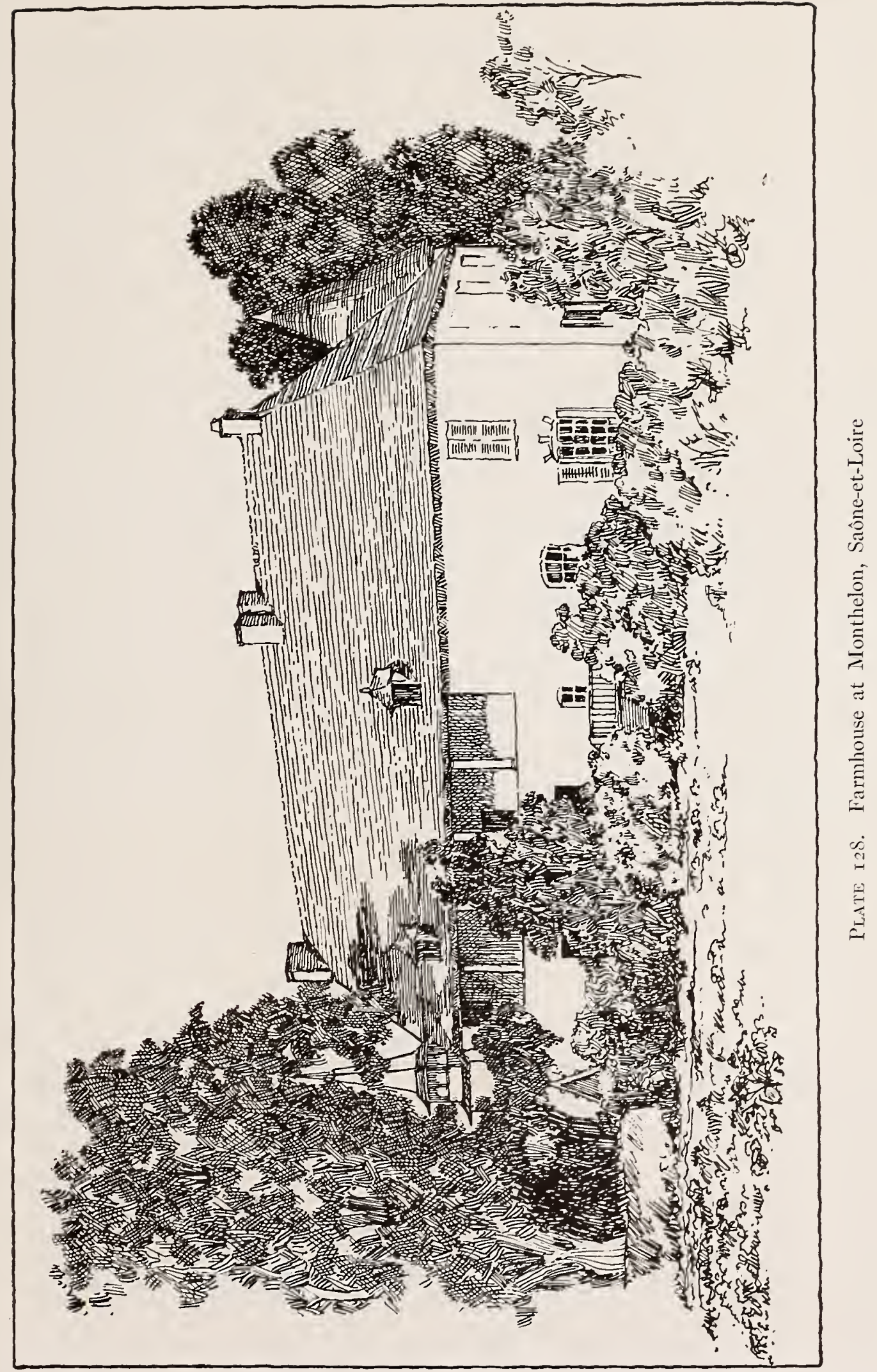





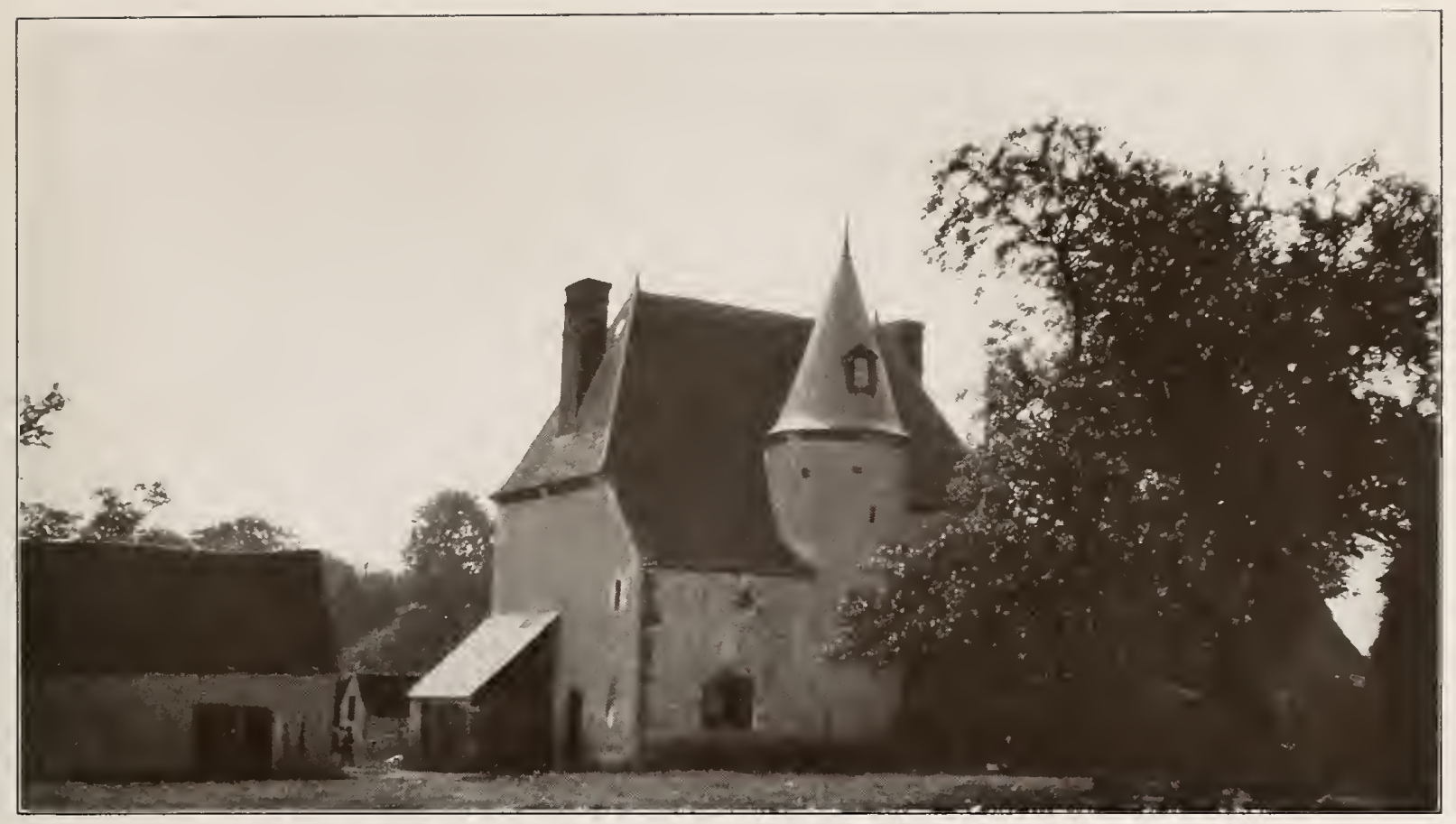

Plate I29. Farmhouse near Le Neubourg, Eure

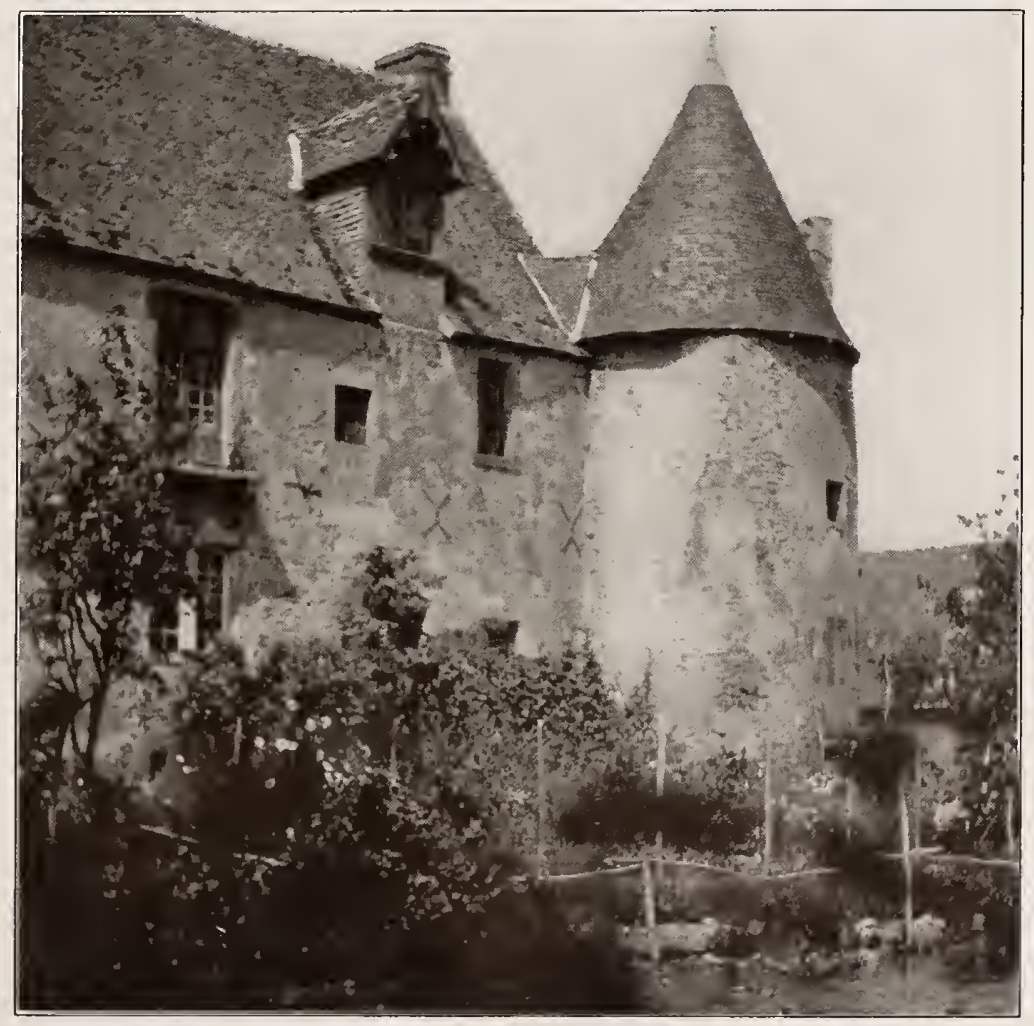

Plate I30. Farmhouse at Monthelon, Saône-et-Loire 



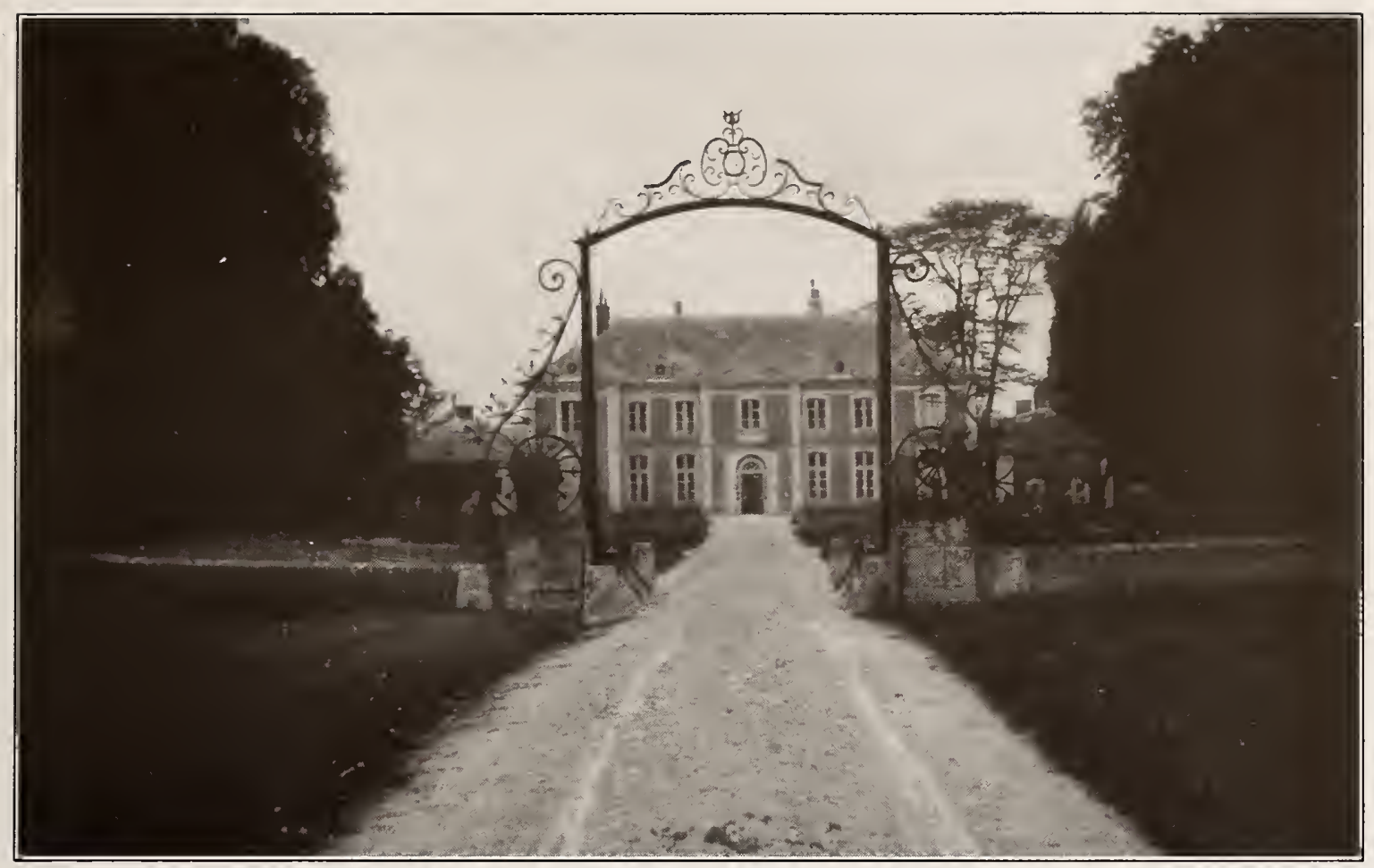

Plate i3I. Château near Millançay, Loir-et-Cher

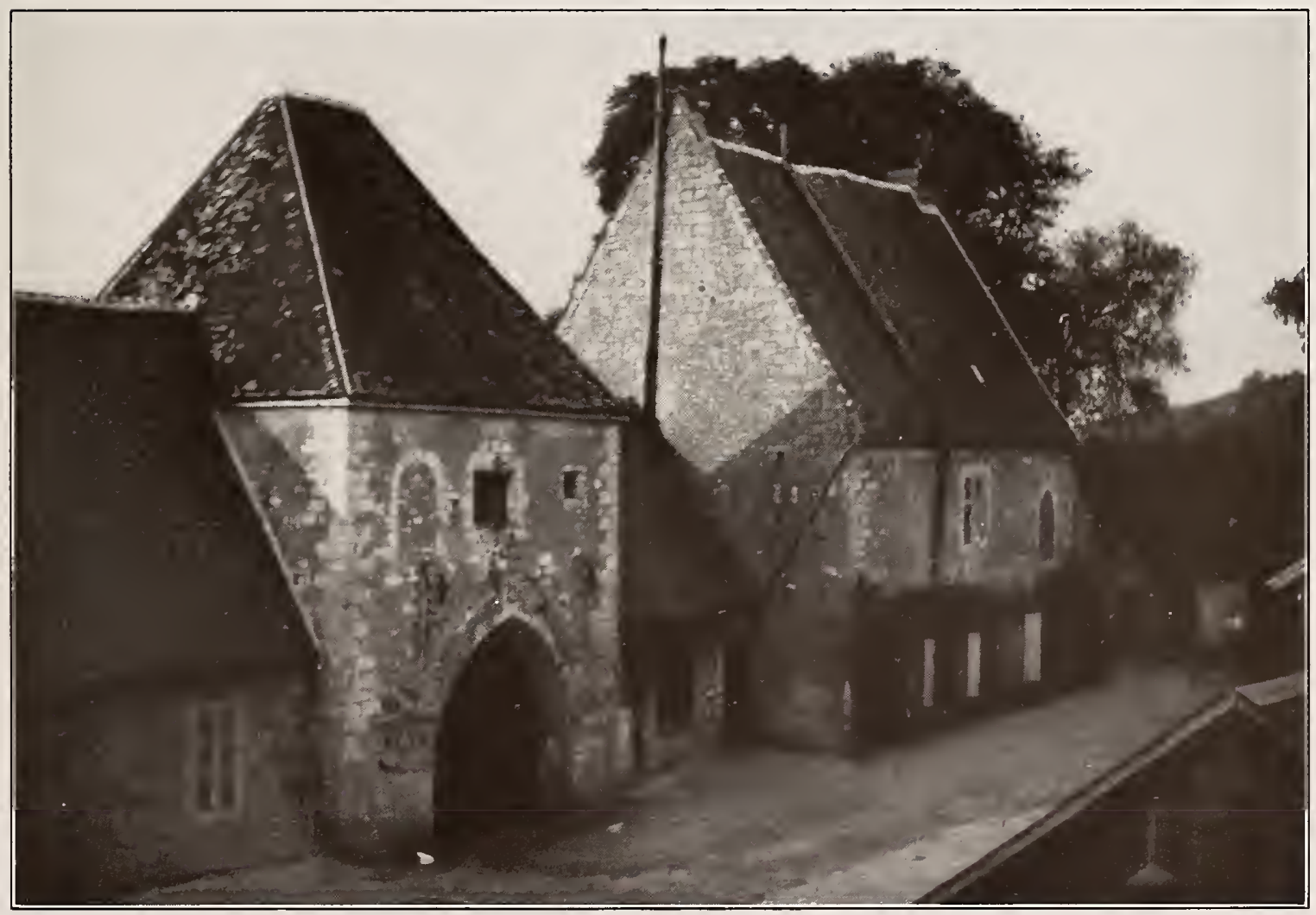

Plate I32. Horse-farm courtyard near Nogent-le-Rotrou, Eure-et-Loir 



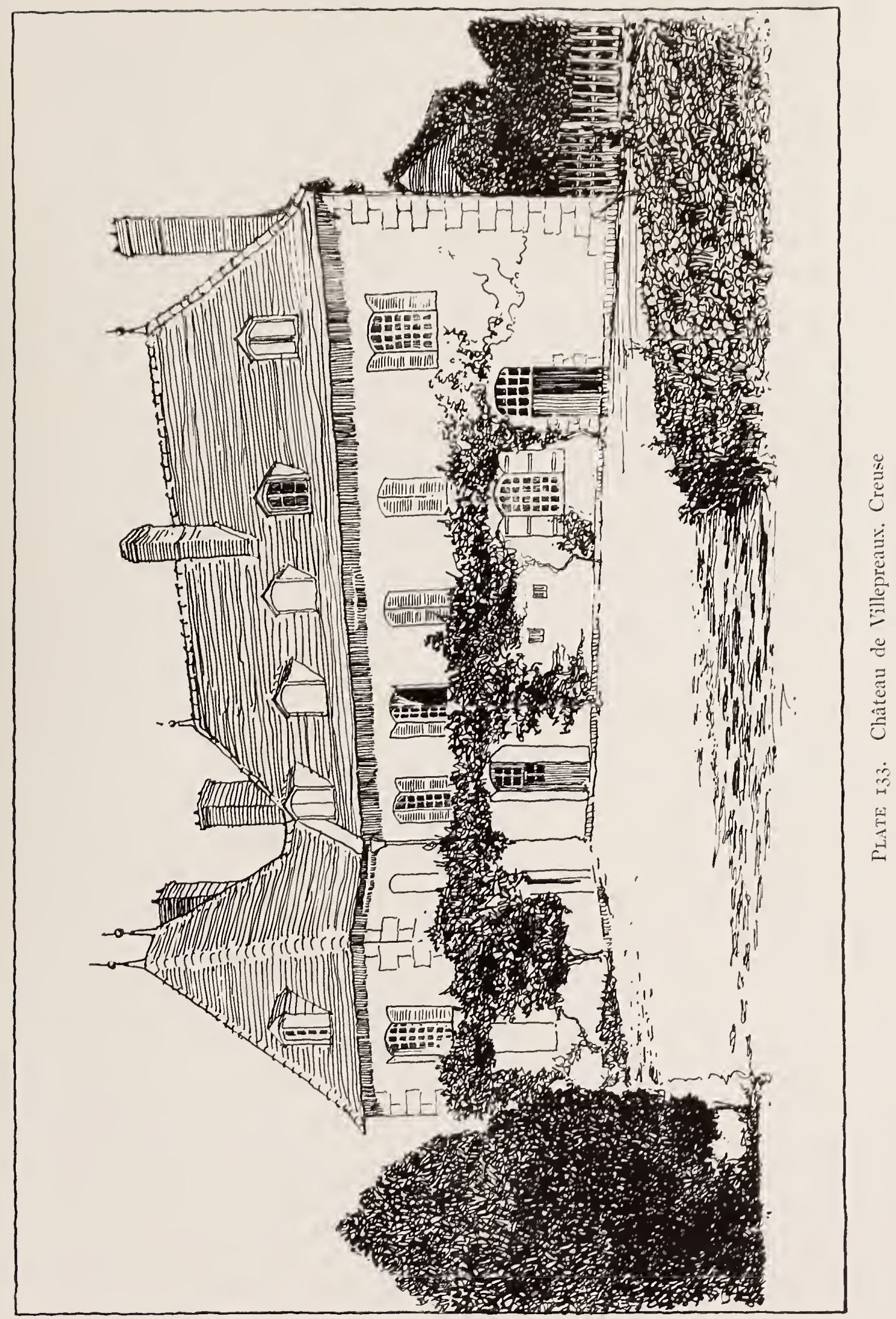





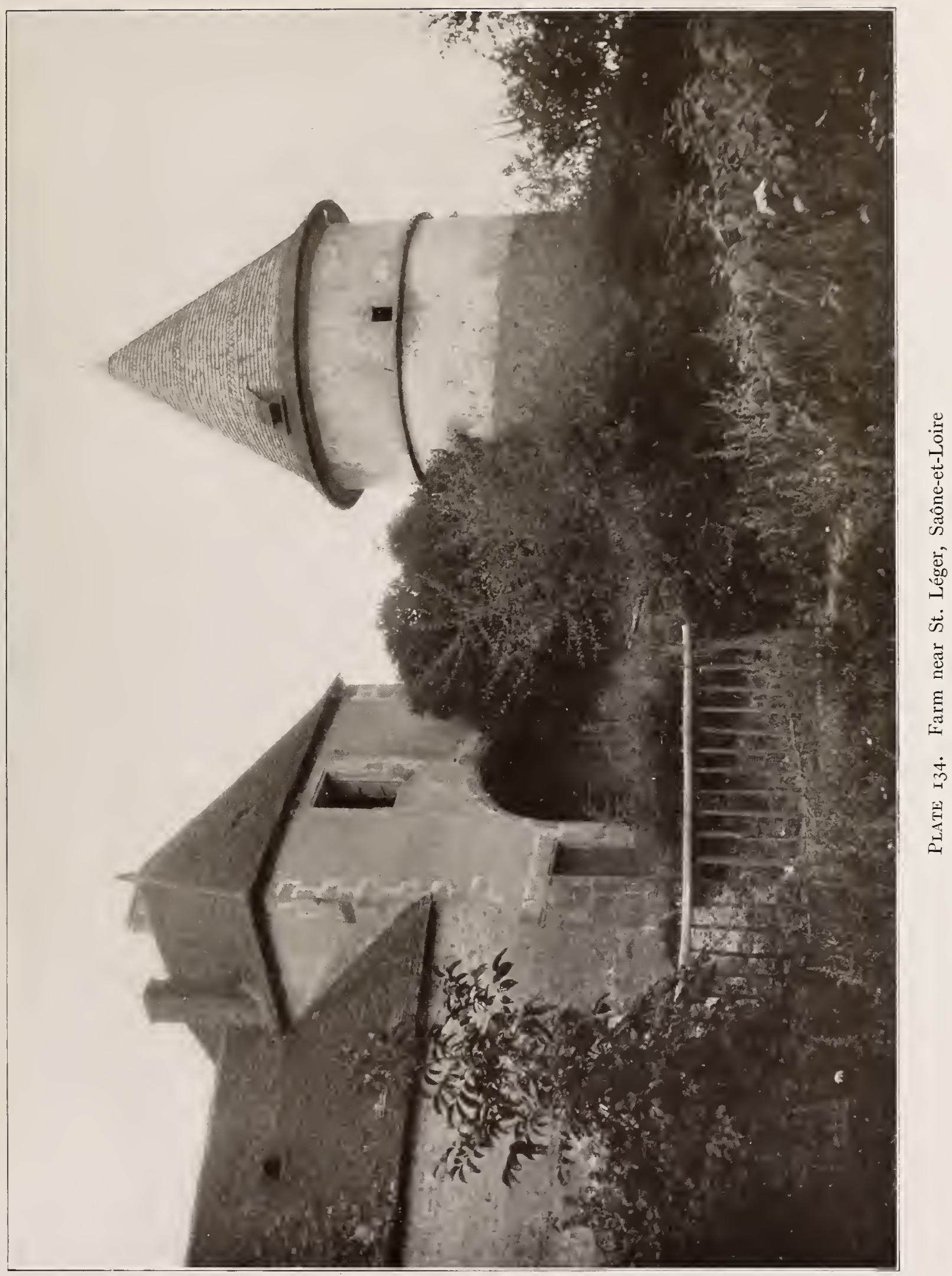





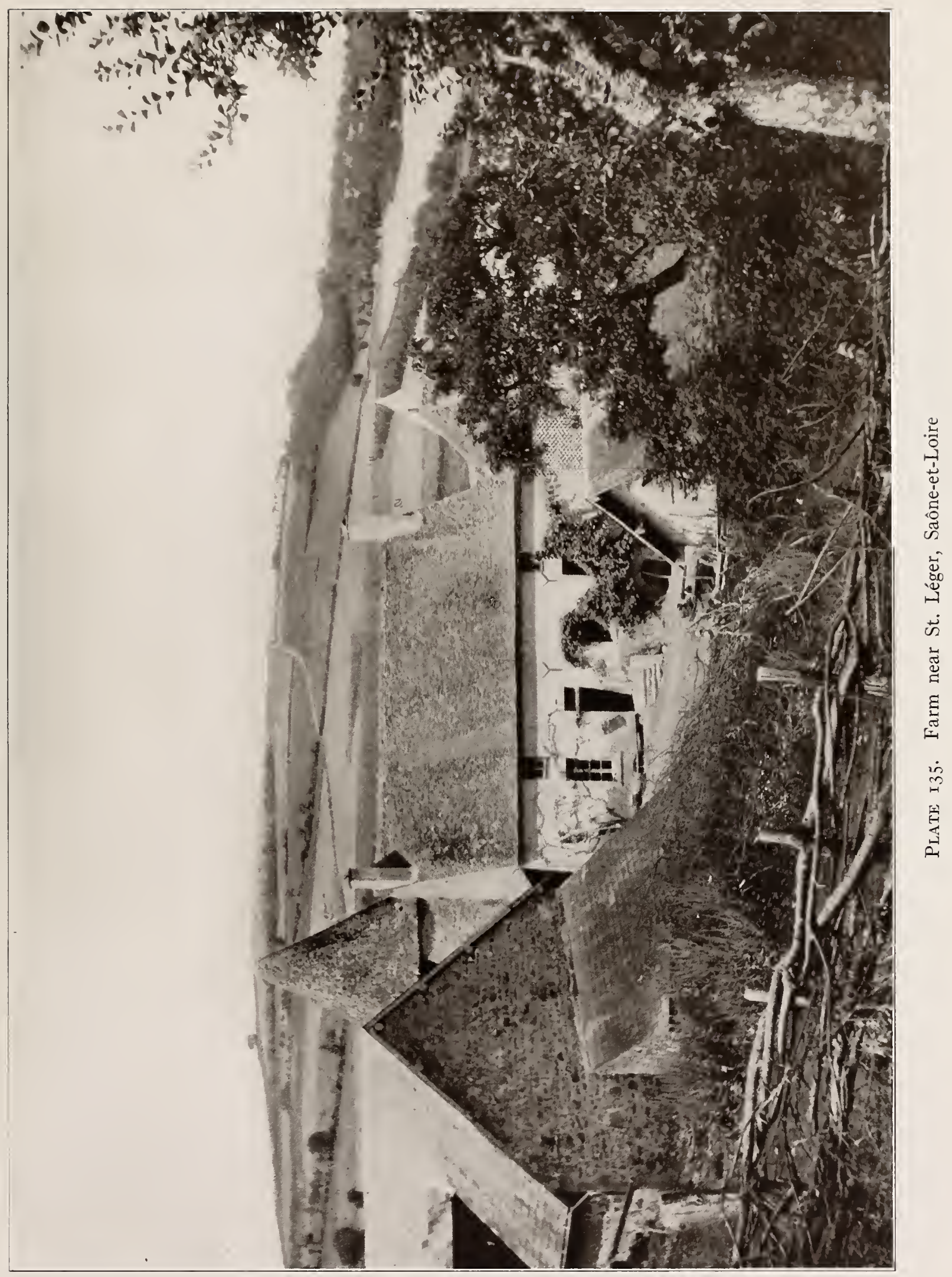





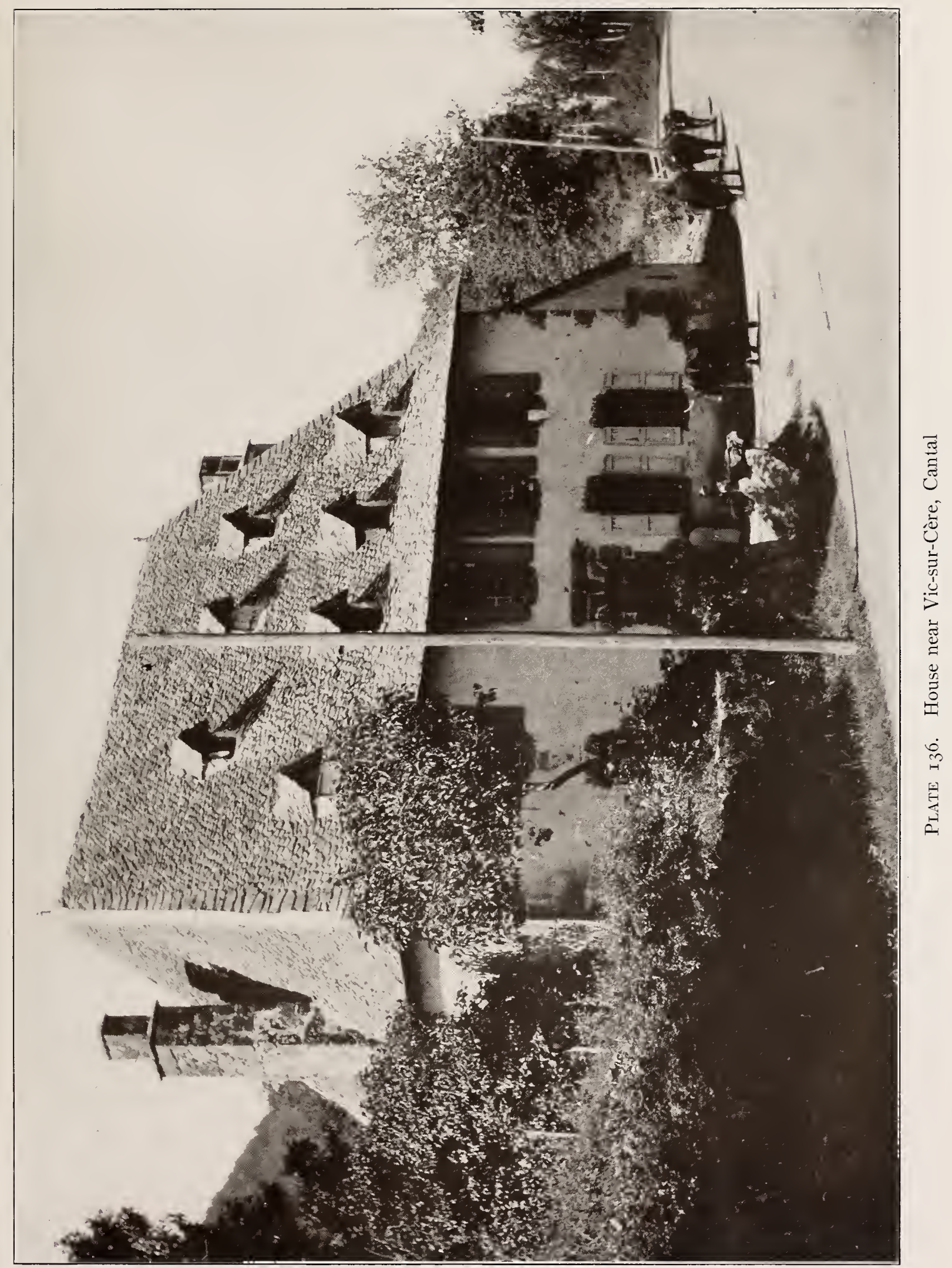





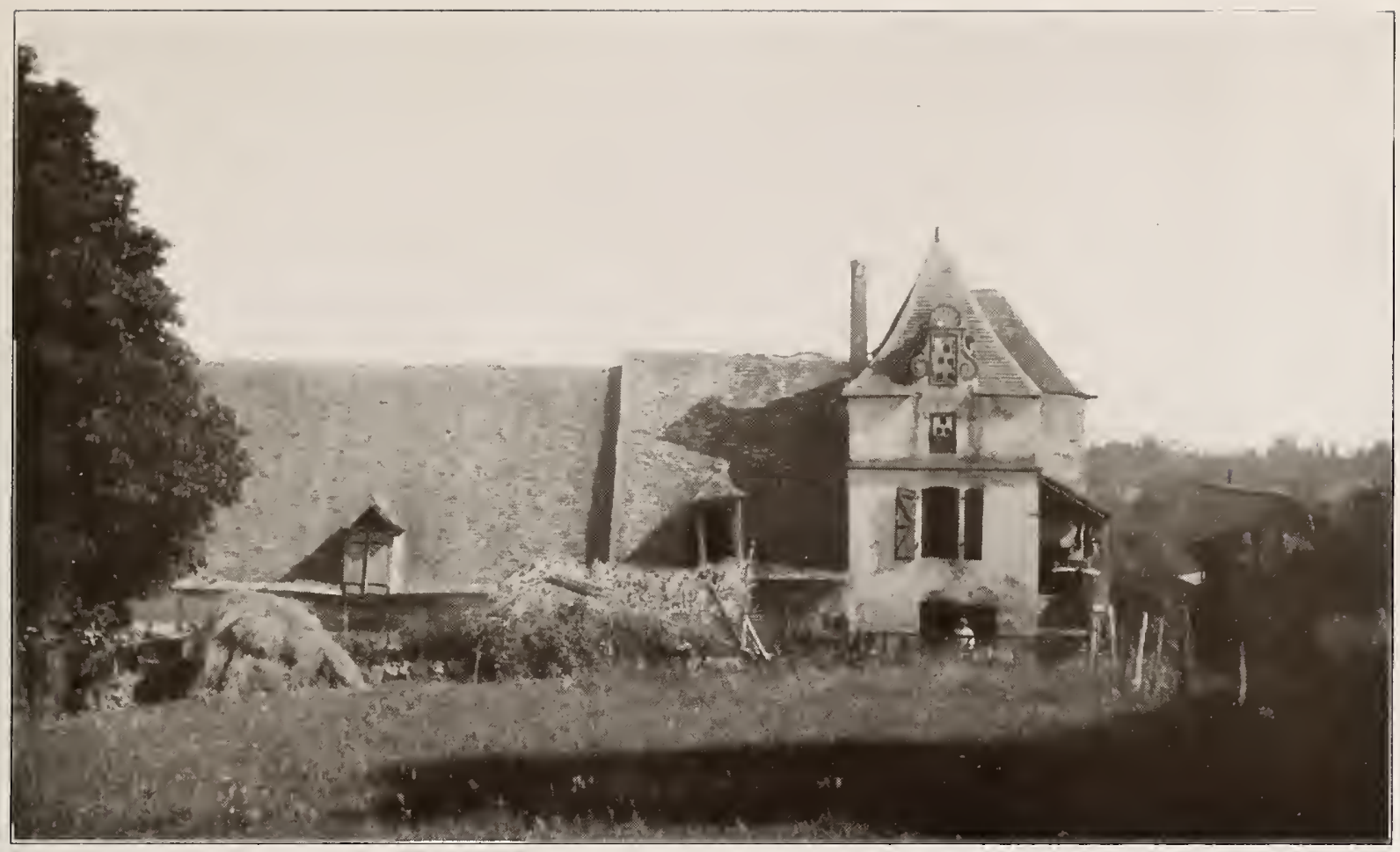

Plate 137. Farm near Gourdon, Lot

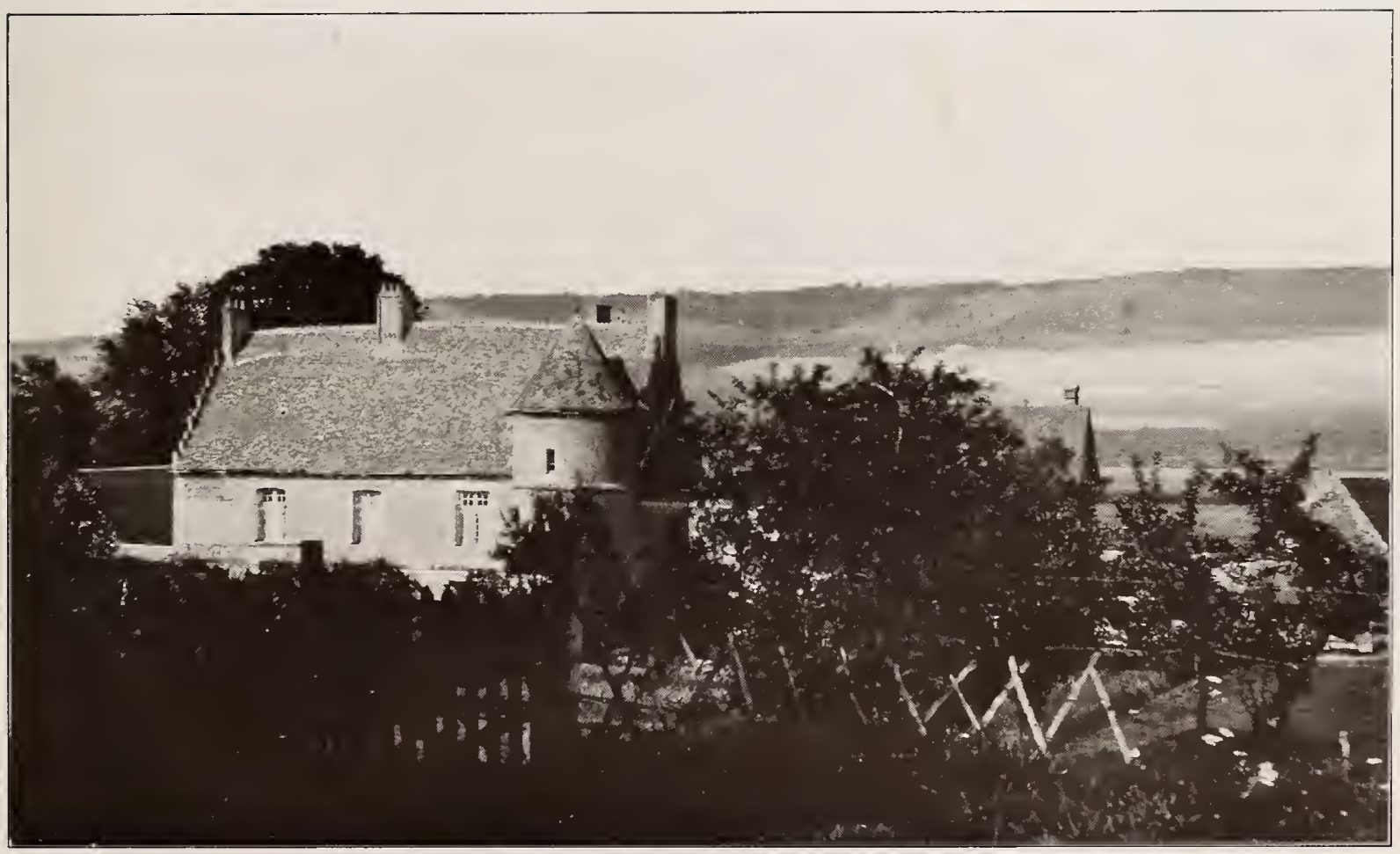

Plate I38. Manoir Duval, near Freulleville, Seine-Inférieure 


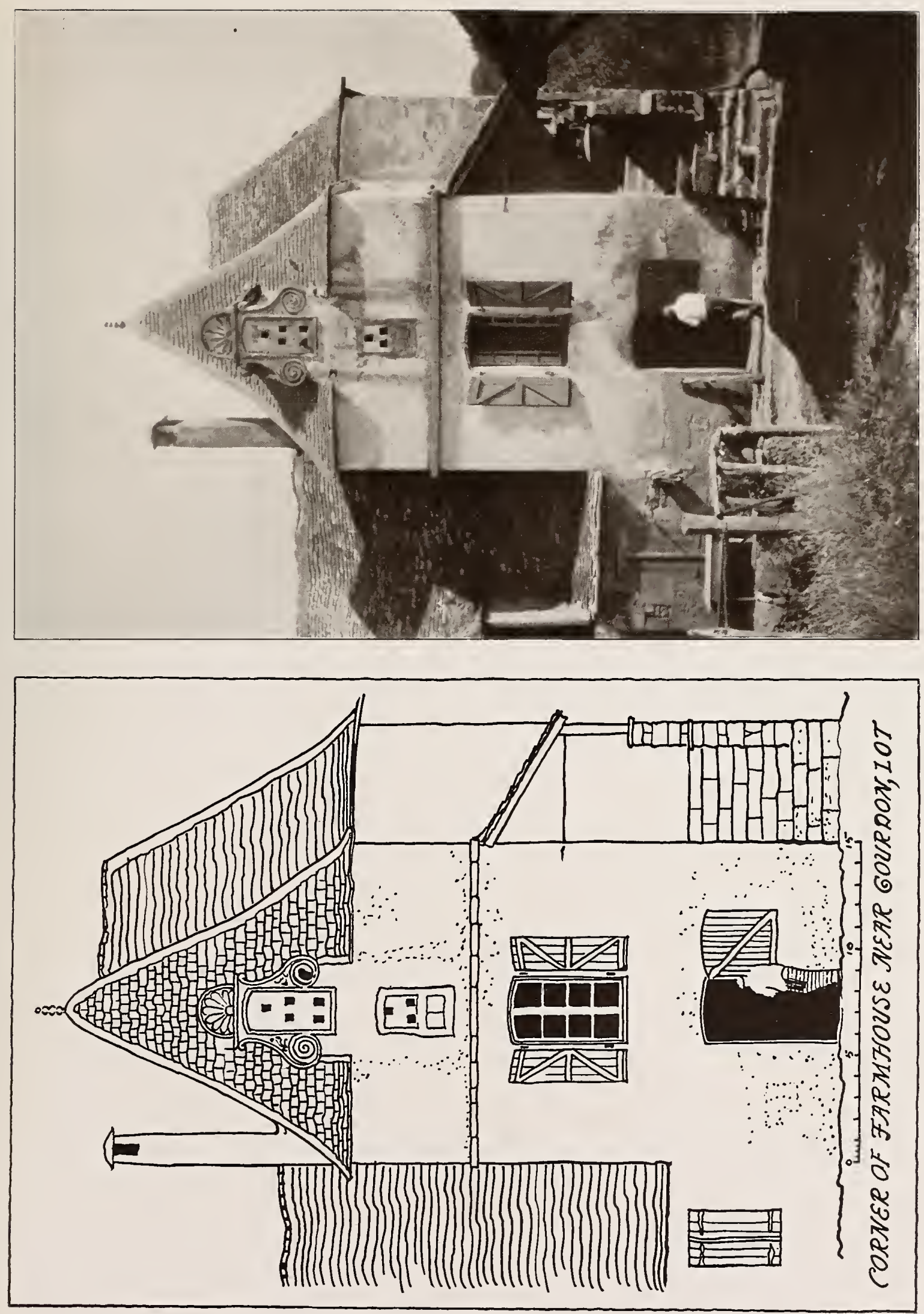

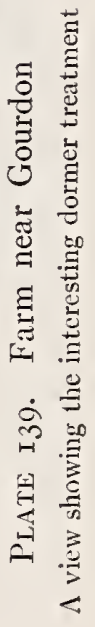





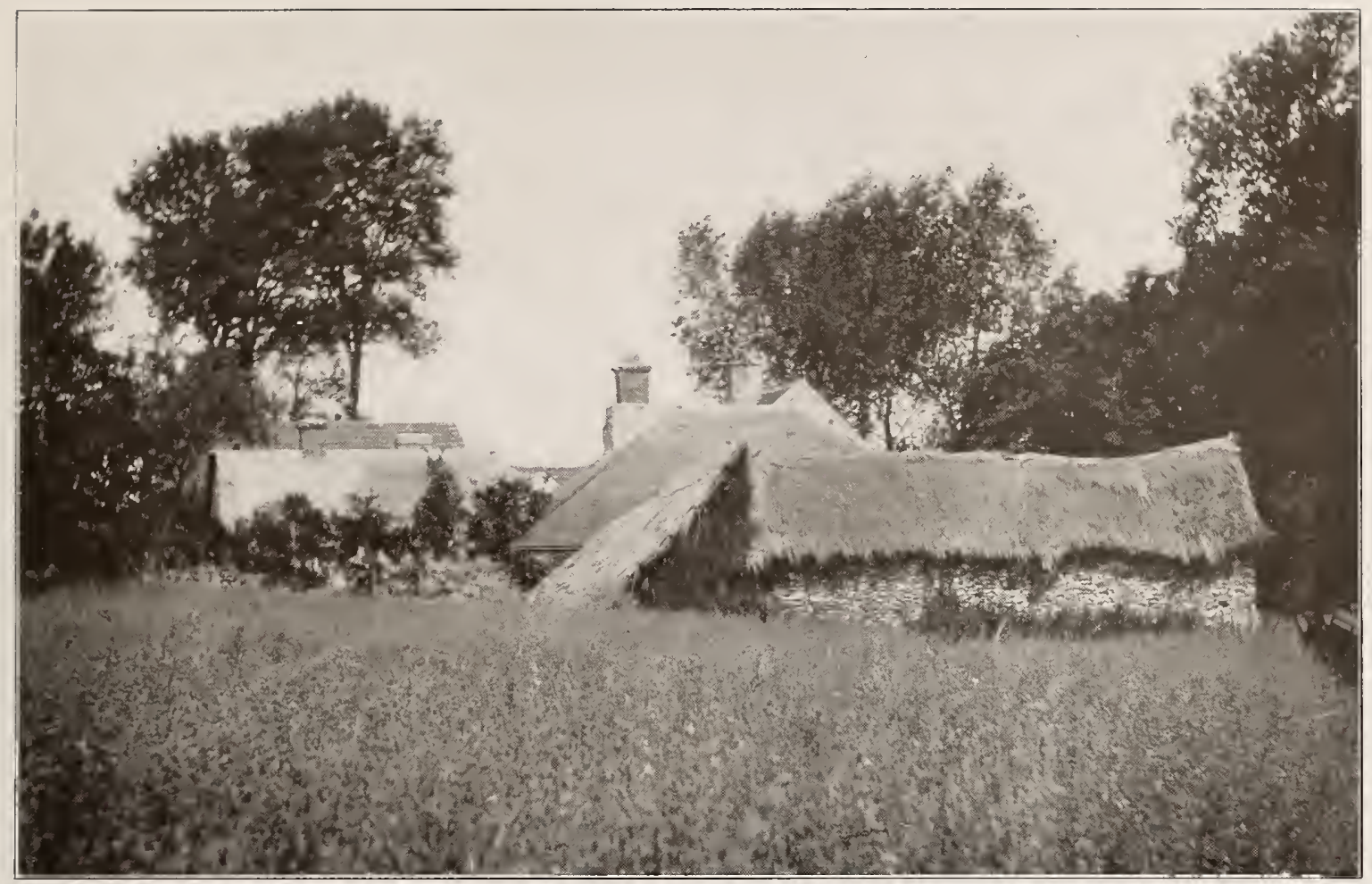

Plate I40. Farm group near Rambouillet, Seine-et-Oise

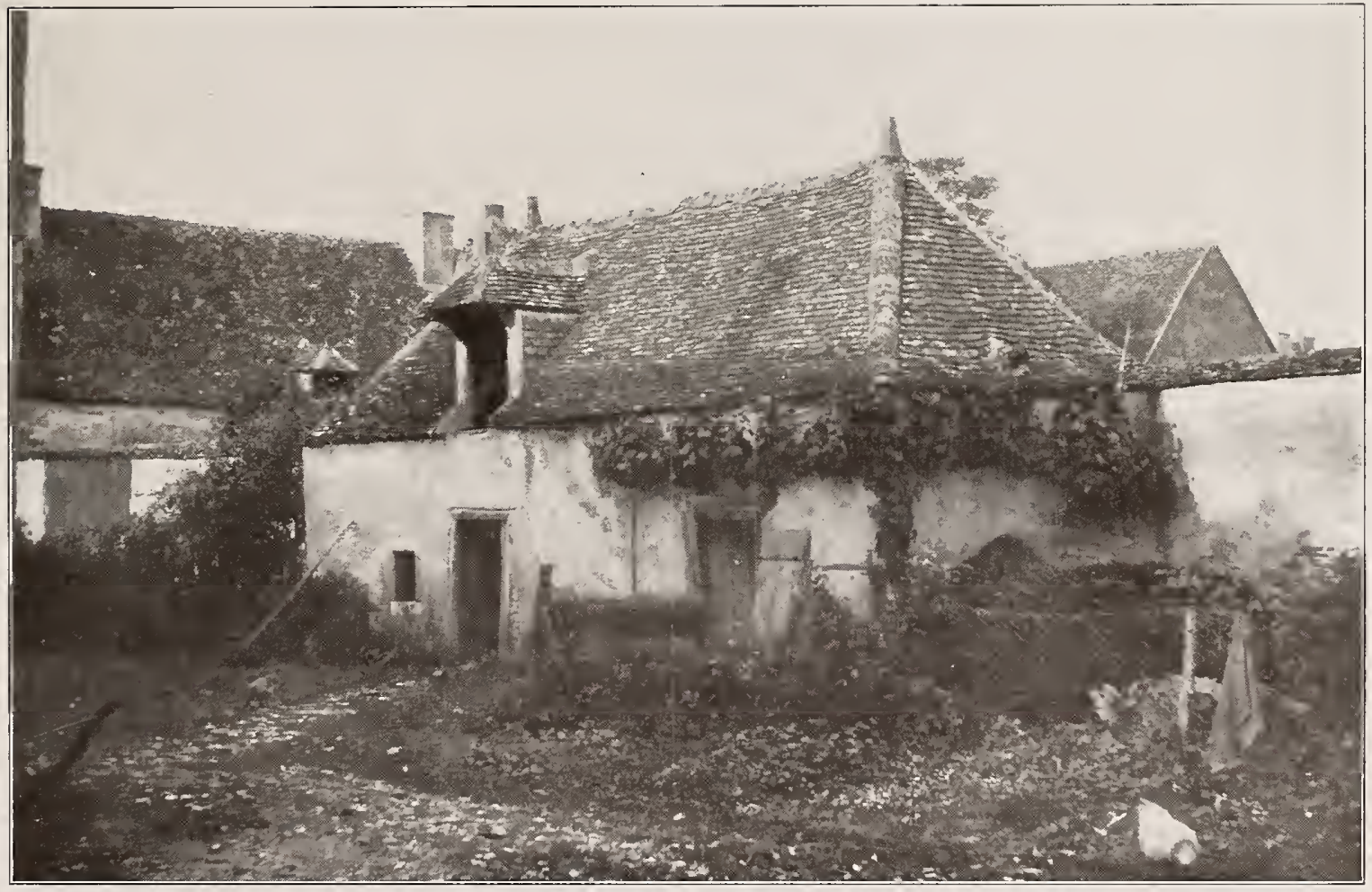

Plate I4I. Stable yard near Demigny, Saône-et-Loire 



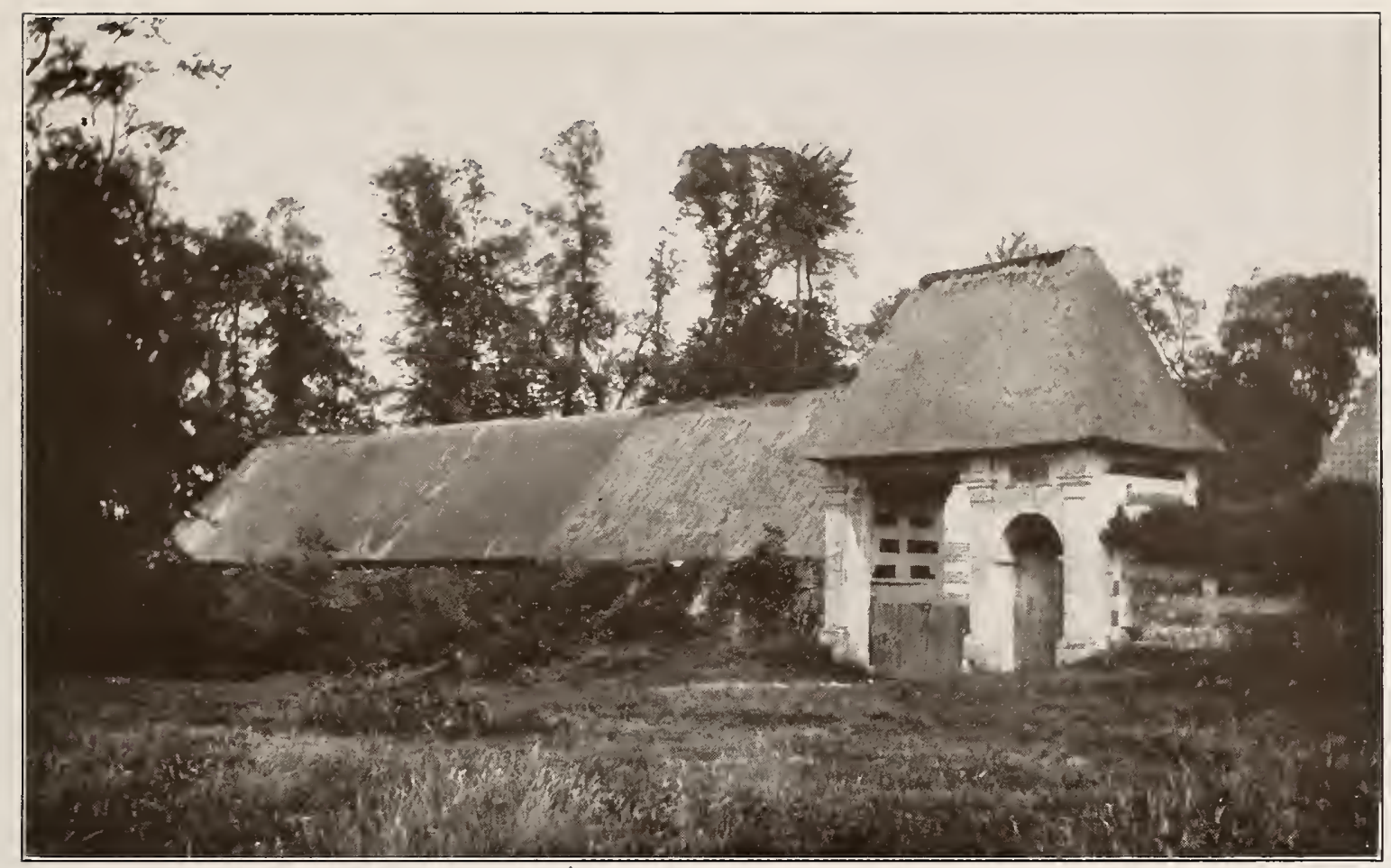

Plate I42. Farm near La Remuée, Seine-Inférieure

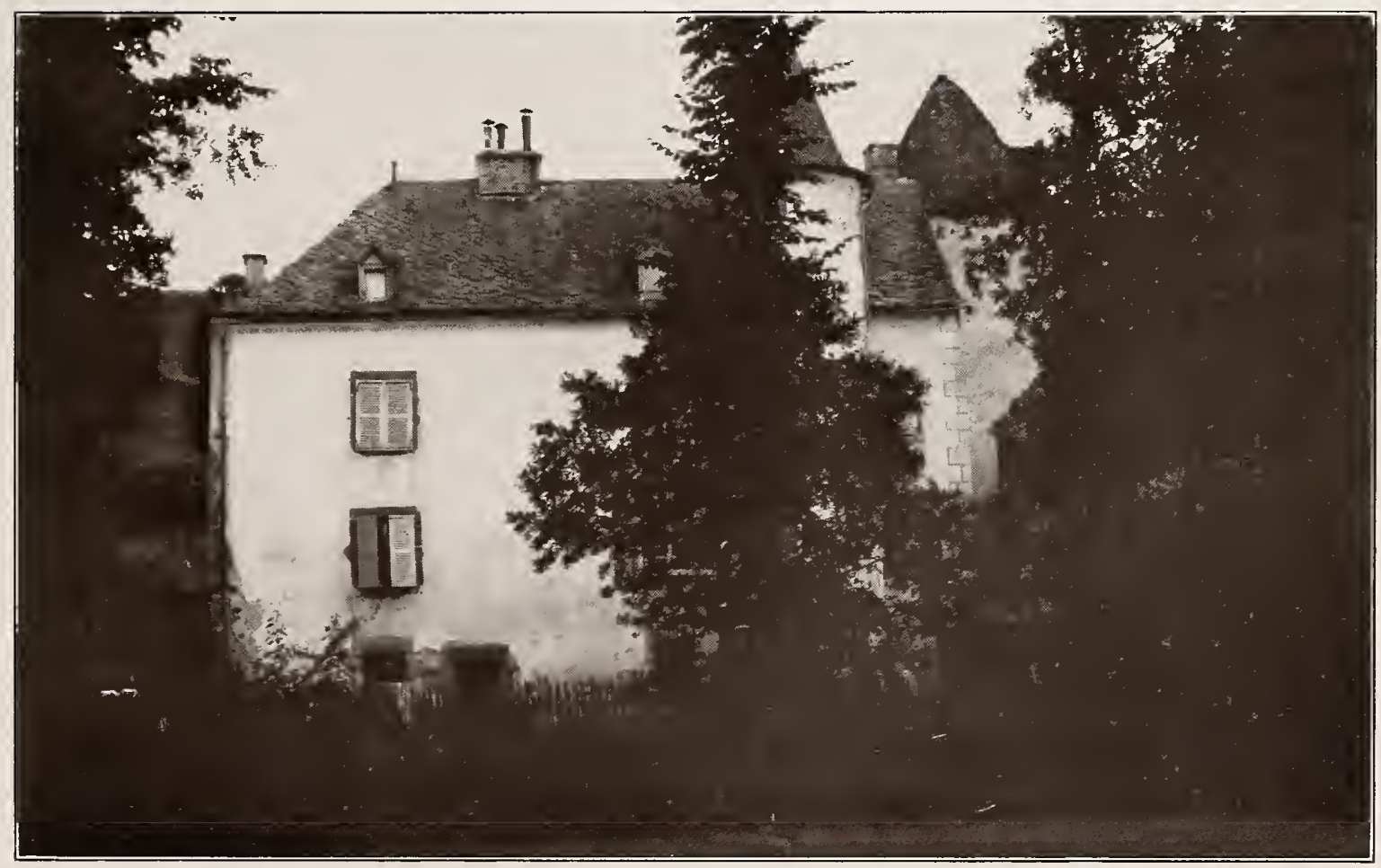

Plate I43. Mill near Murat, Cantal 



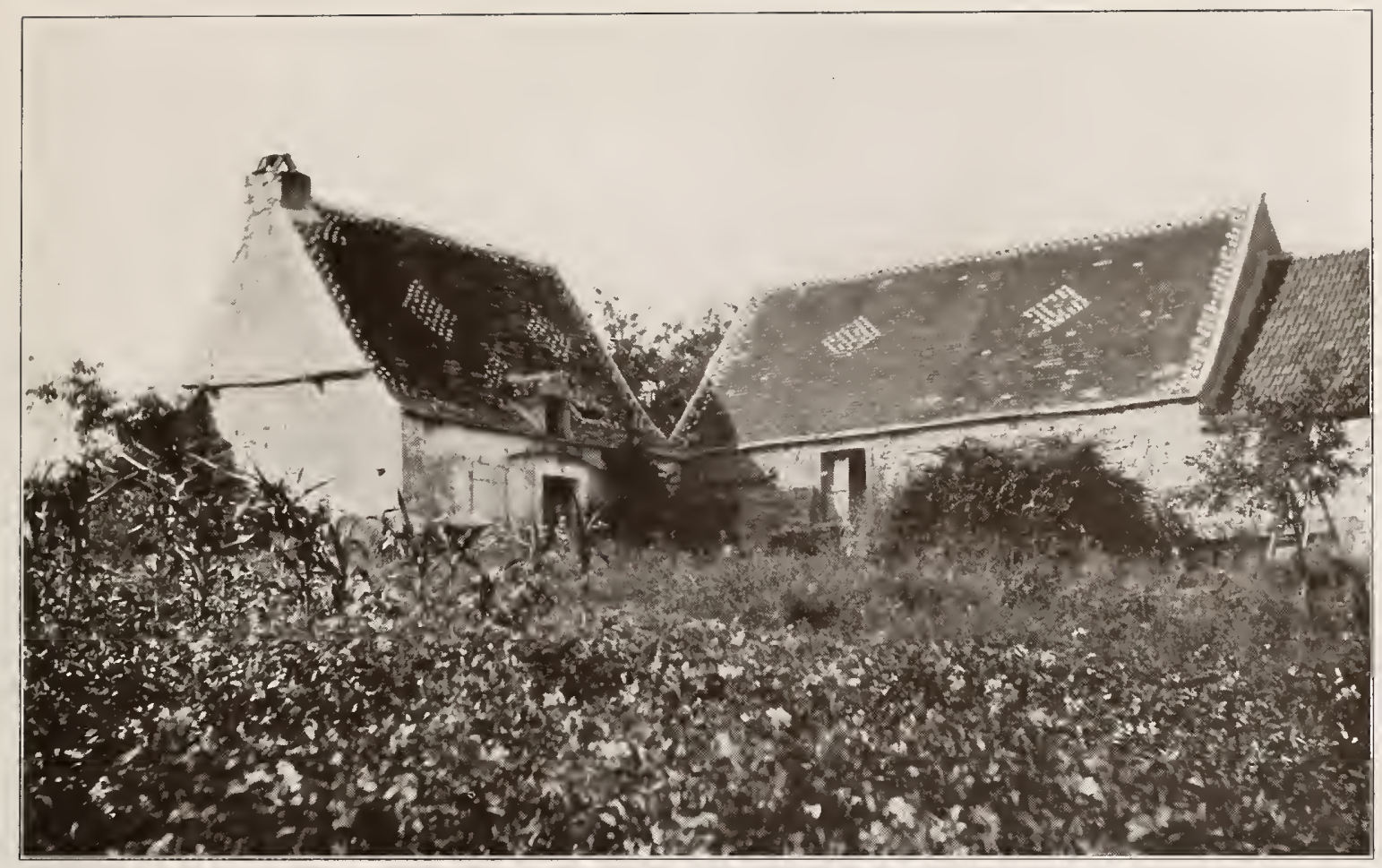

Plate I44. Farm near Domme, Dordogne

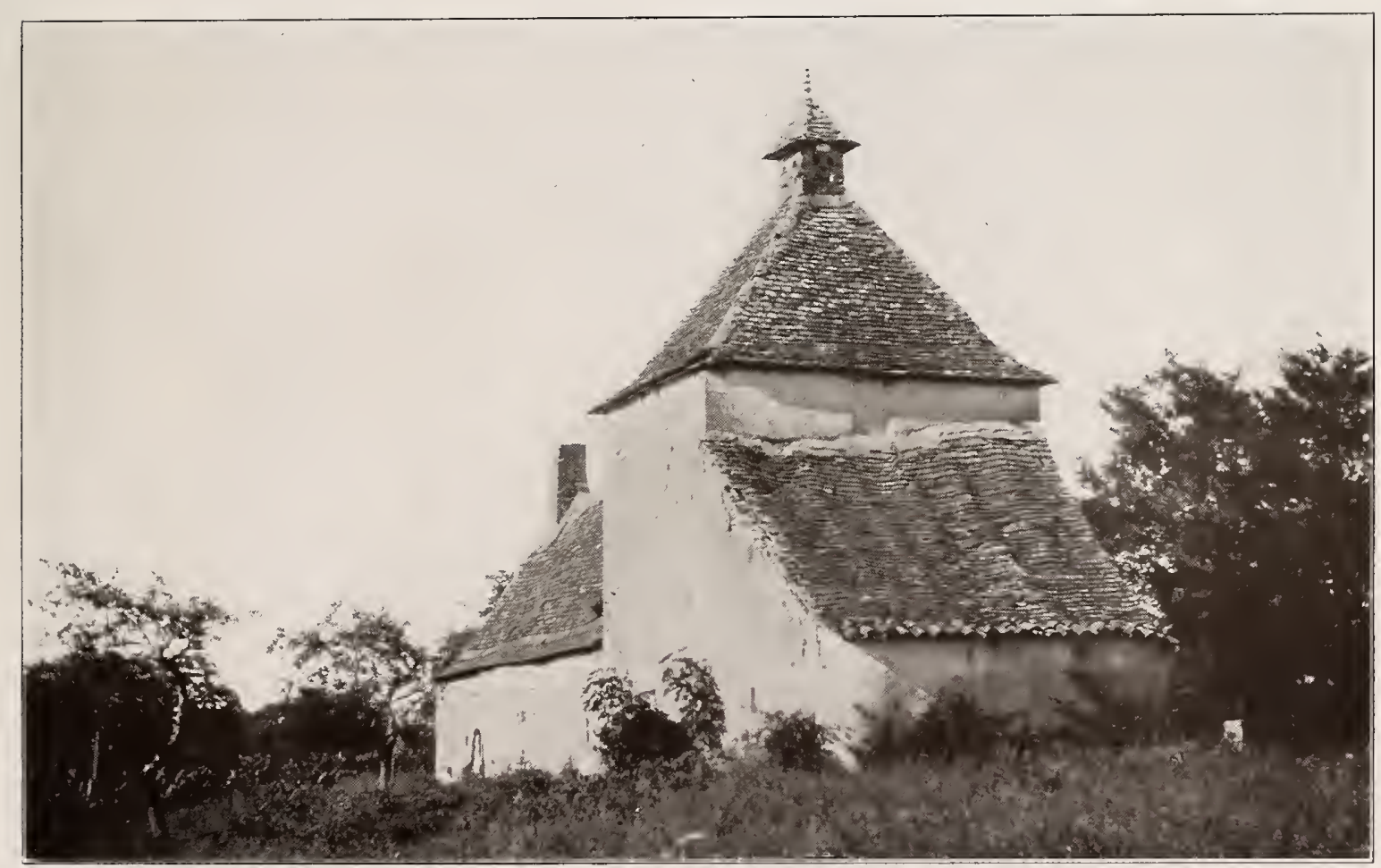

Plate I45. Farm group near Gourdon, Lot 



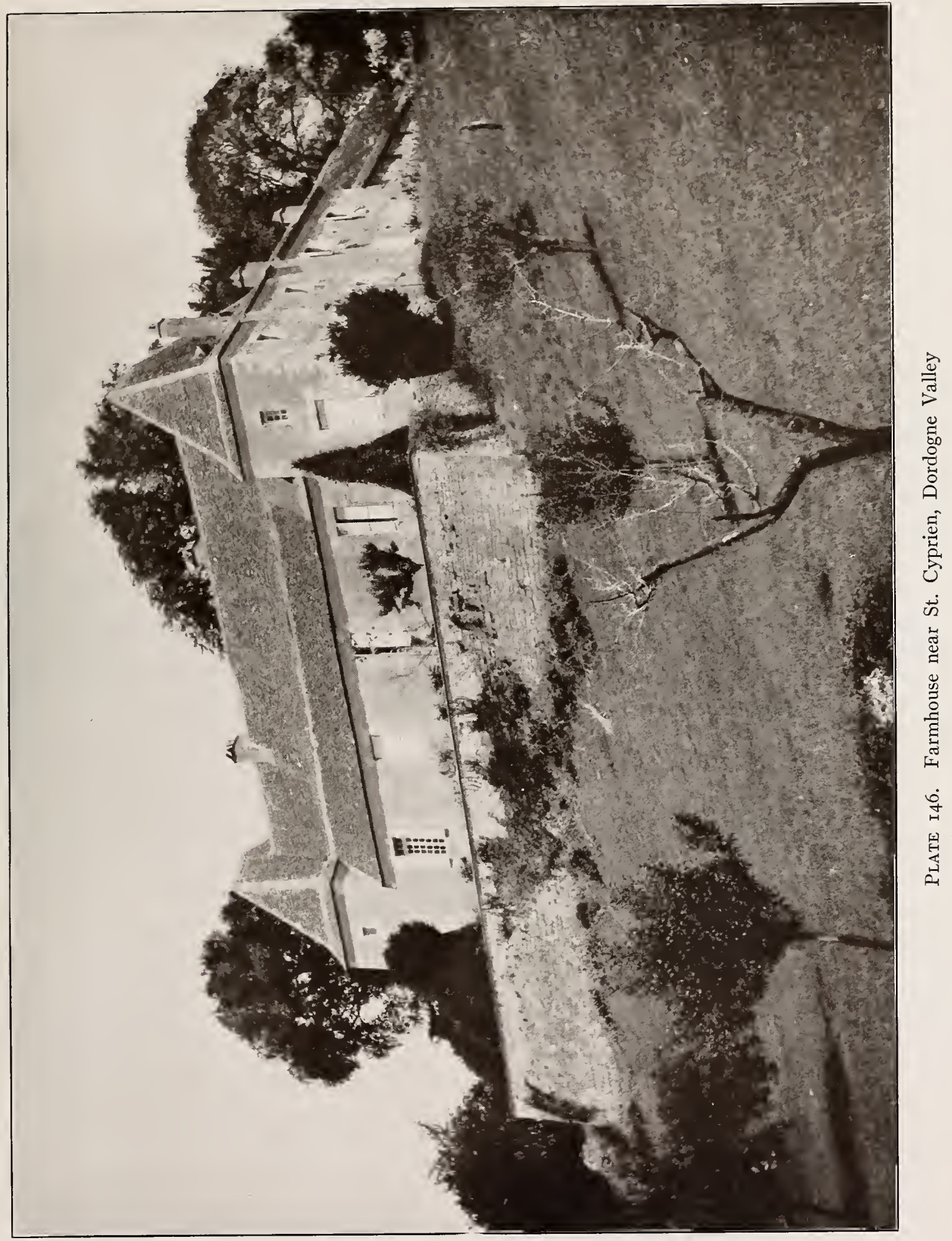





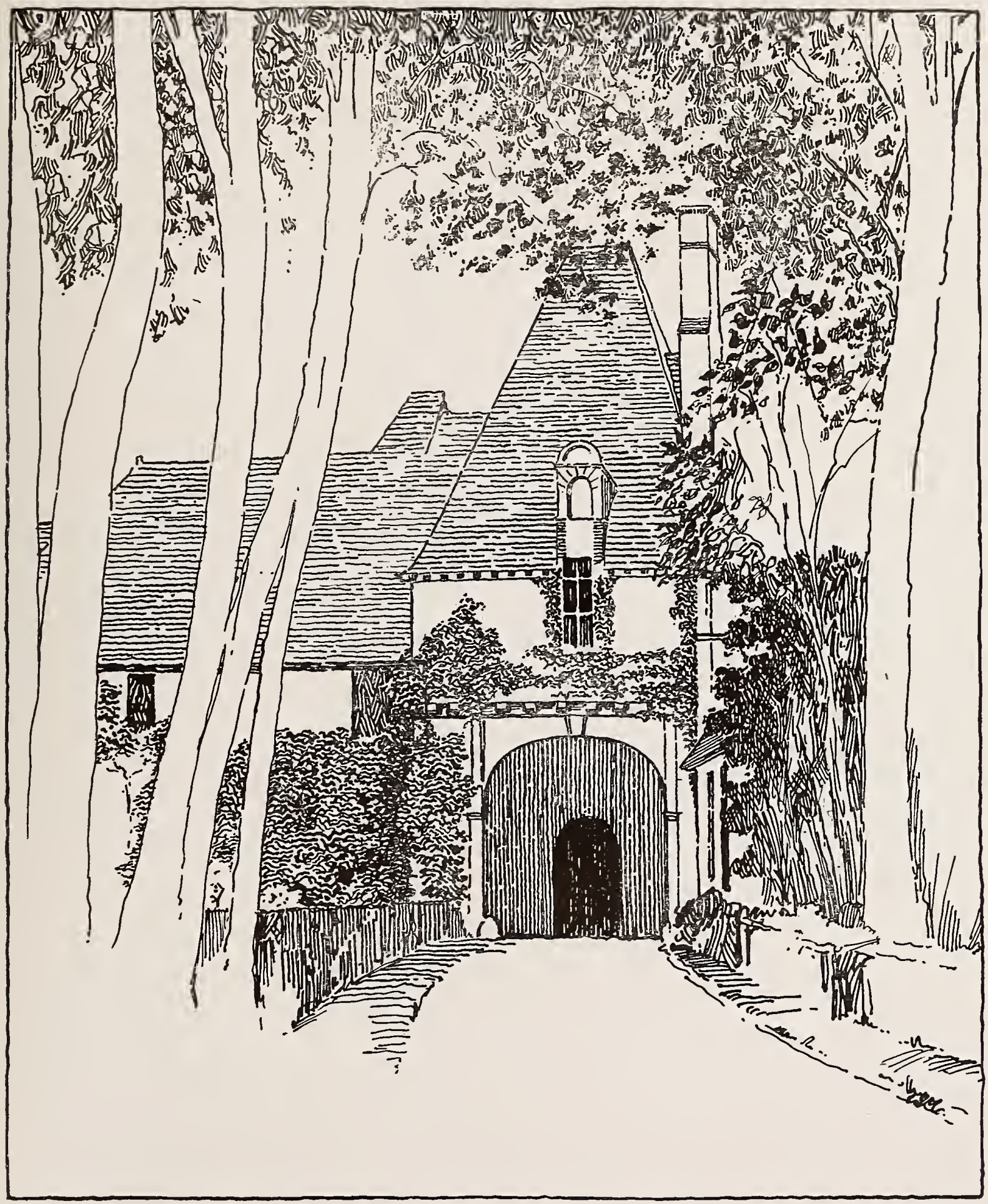

Plate I47. Manor at Vaucelles, Calvados 



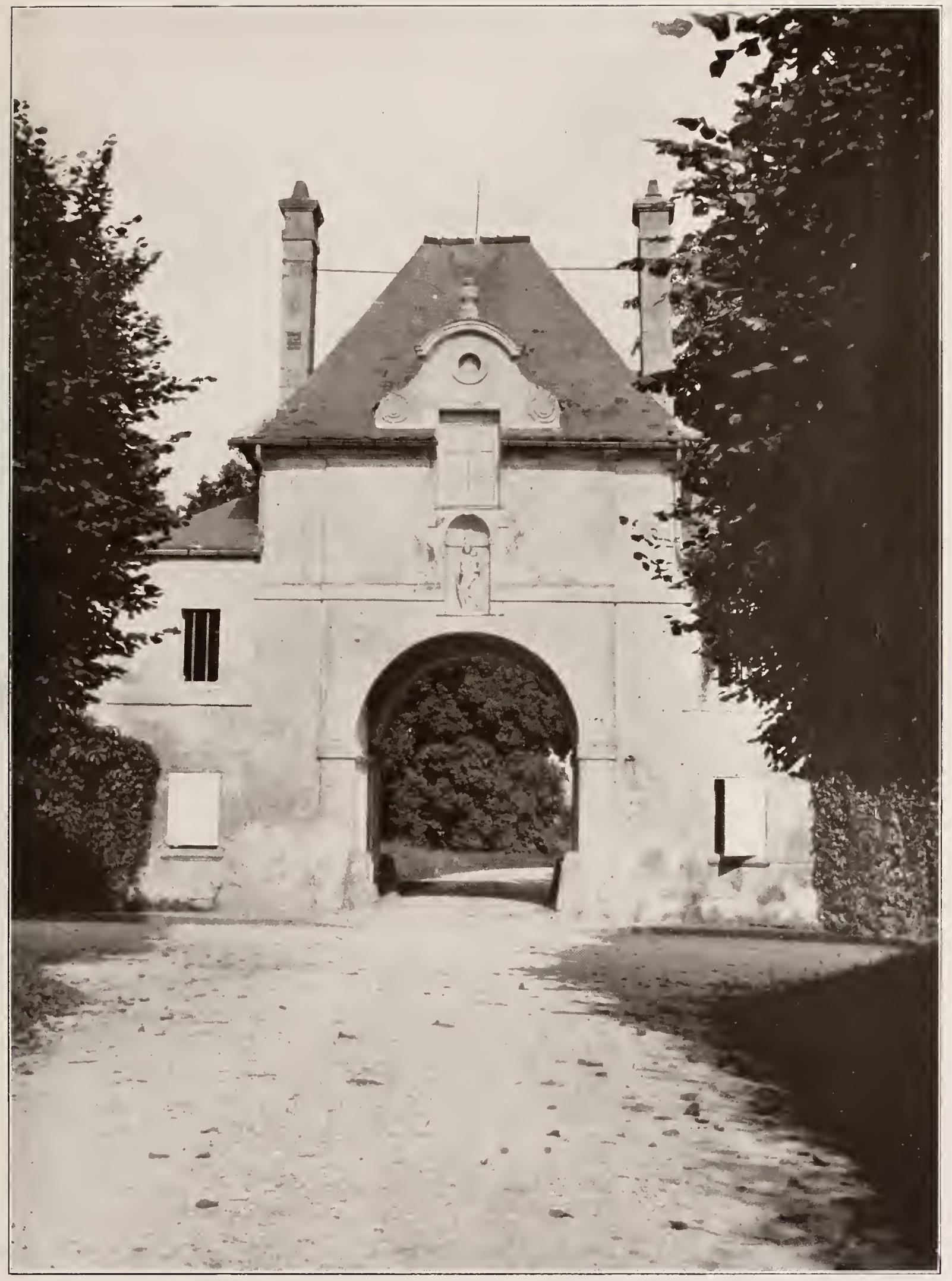

Plate I48. Gatehouse of Château de Royalhen, South Compiègne 



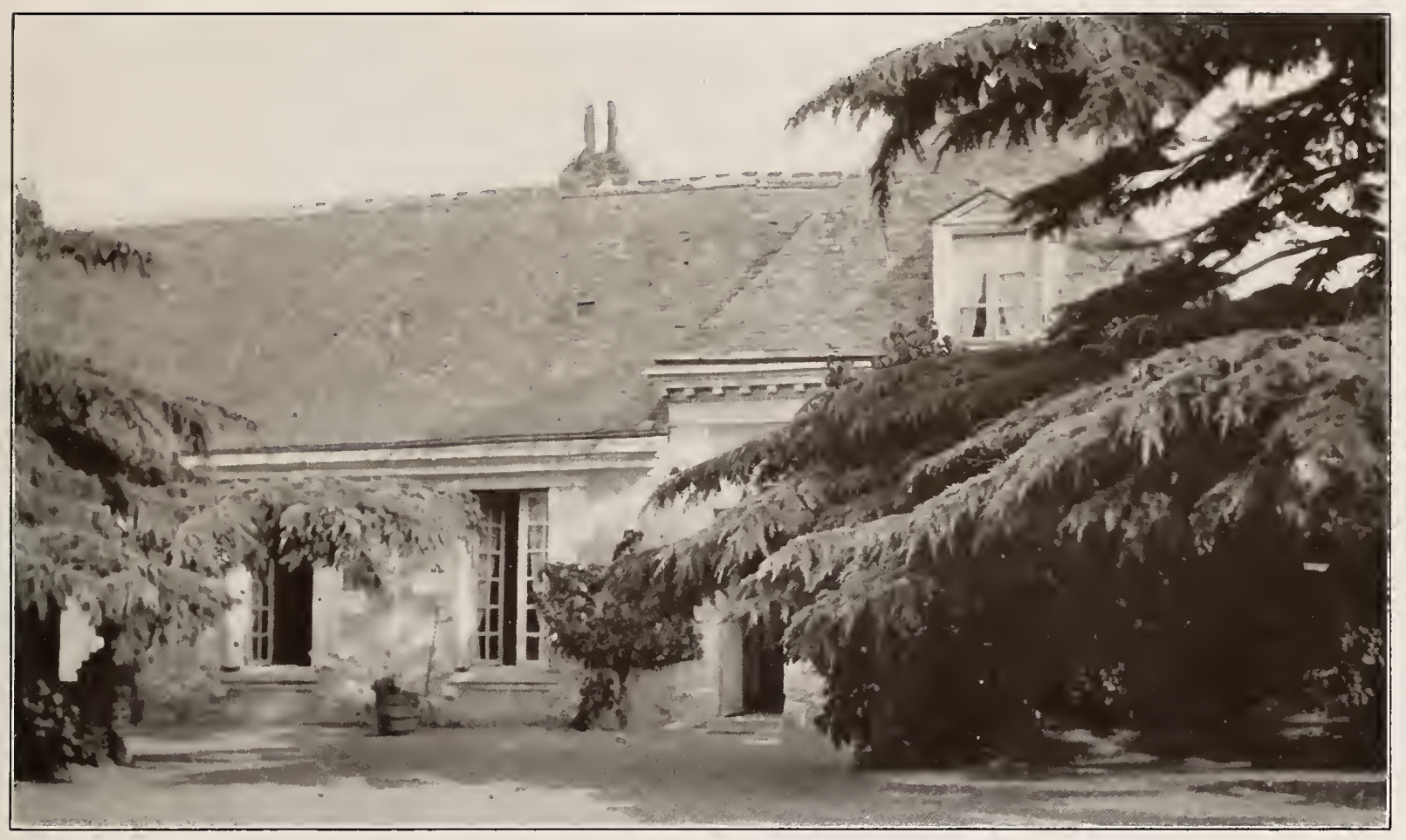

Plate I49. House at St. Symphories, Tours

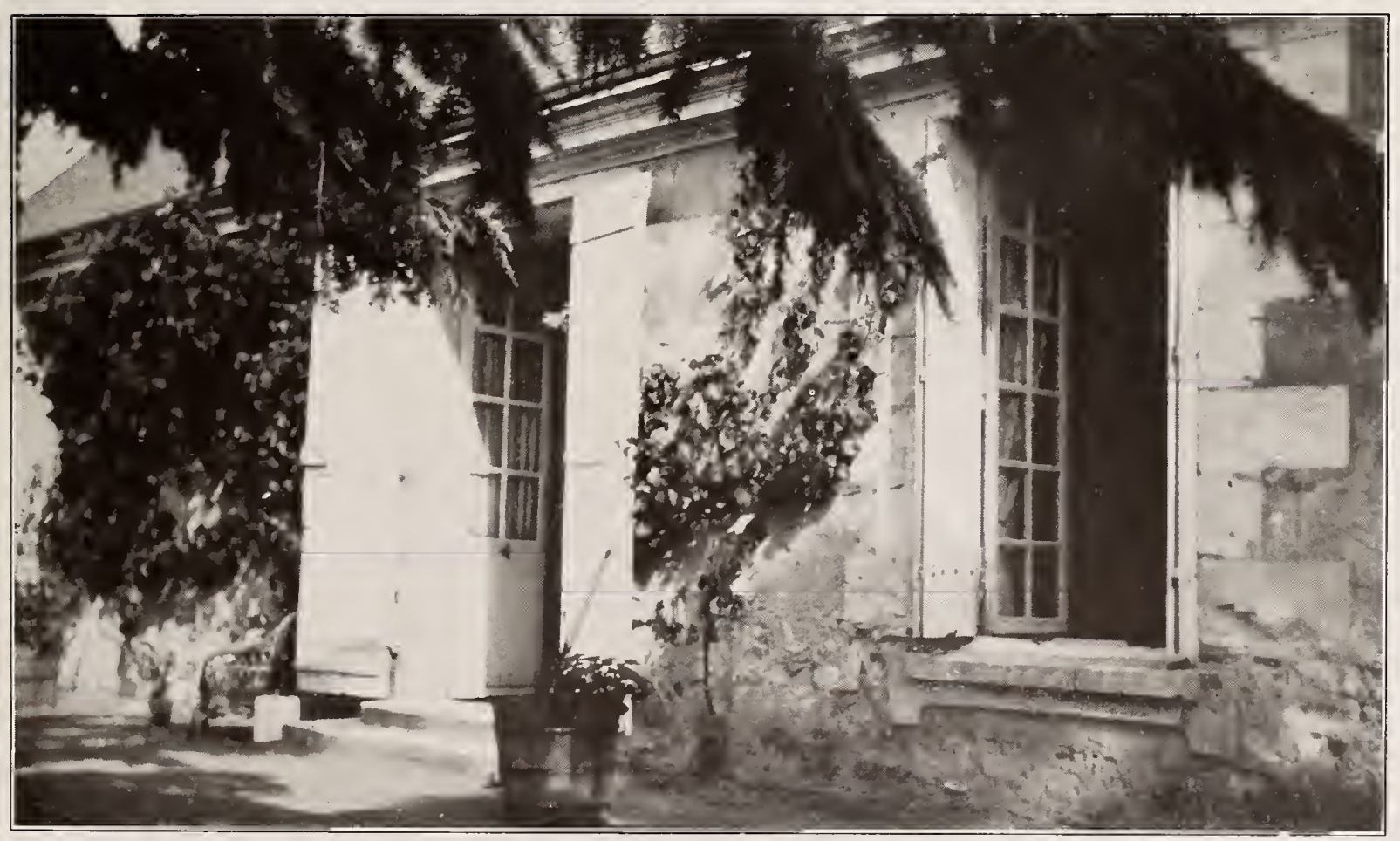

Plate 150. House at St. Symphories, Tours 



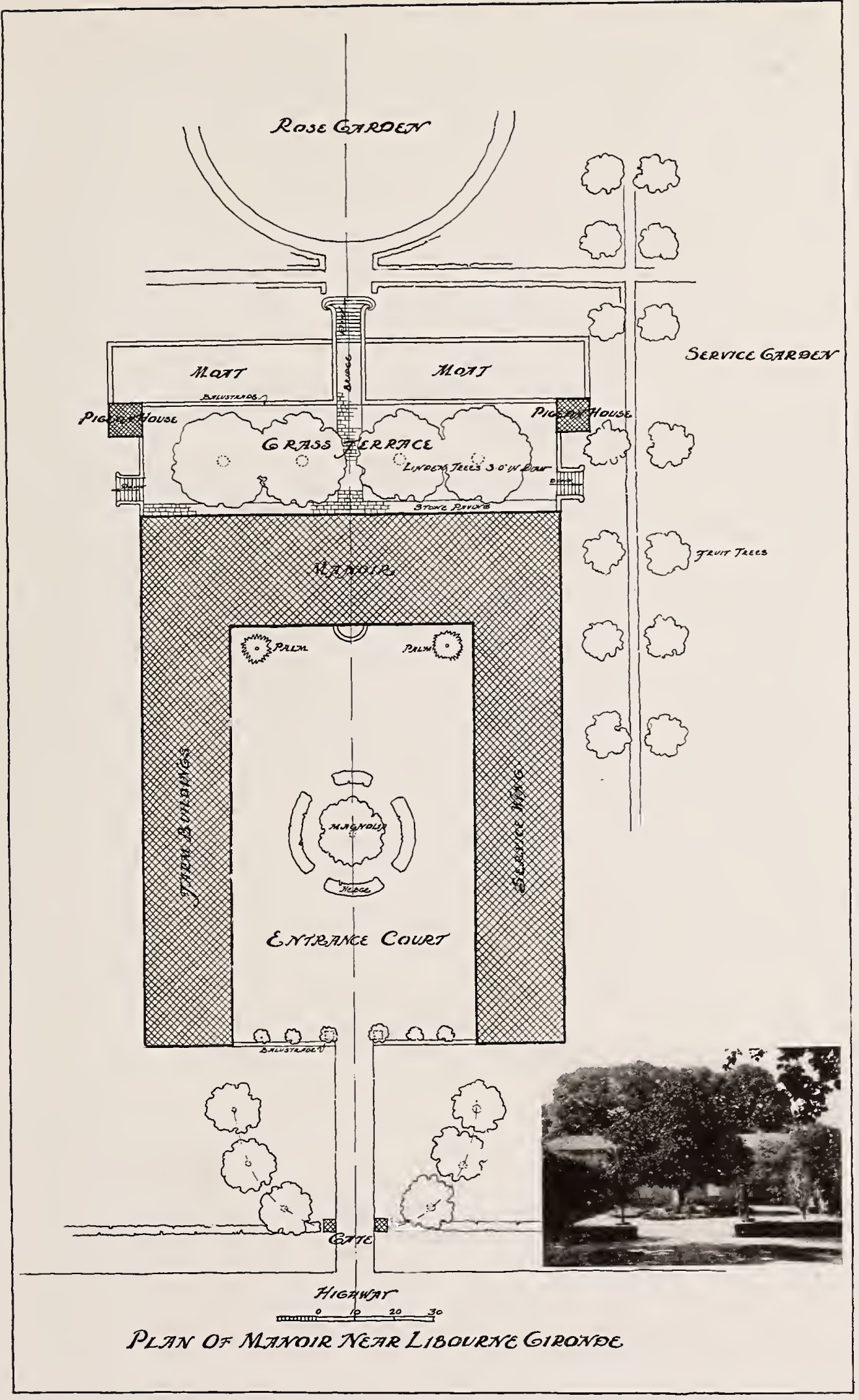

Plate I5I. Plan of manor near Libourne, Gironde 



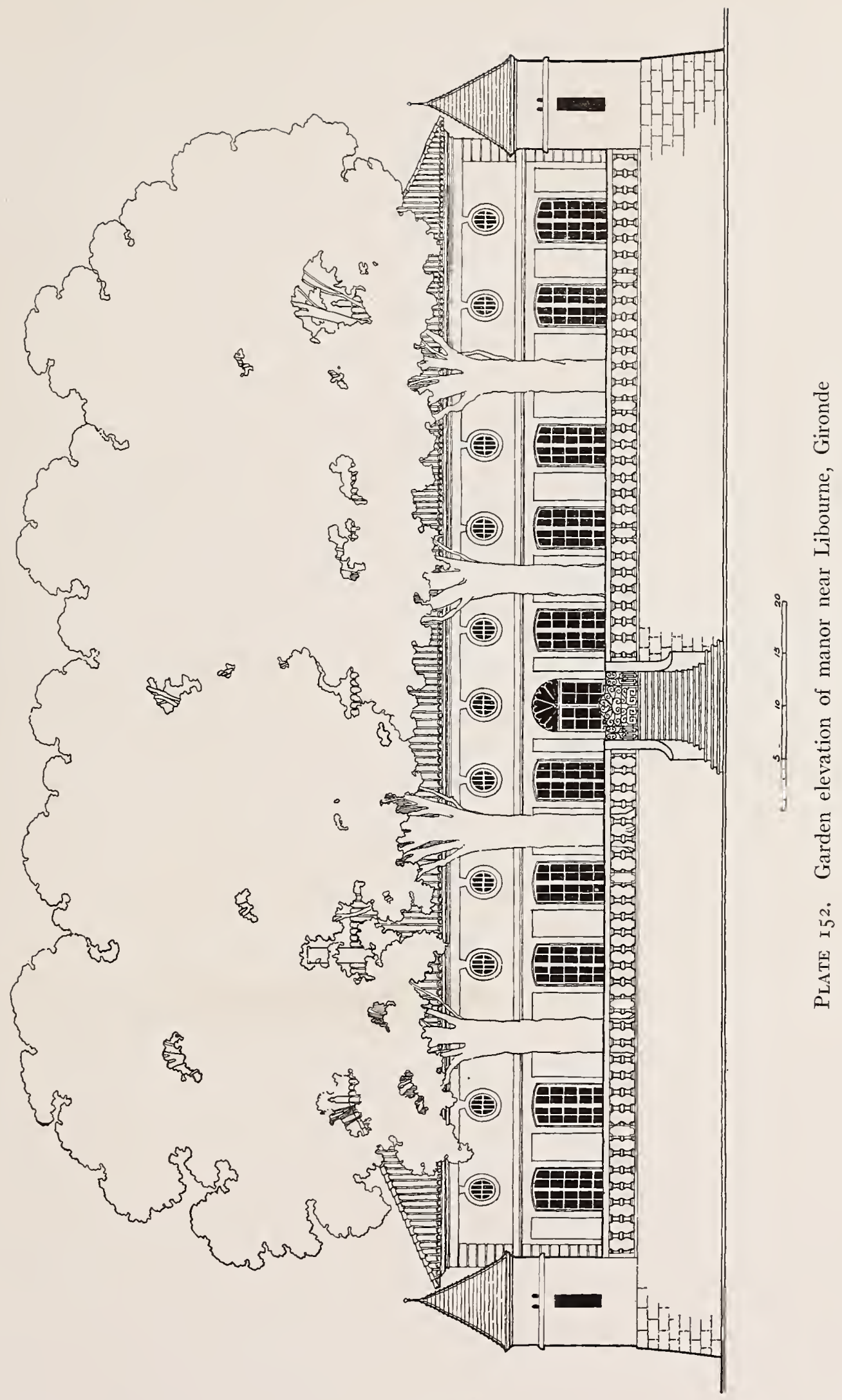





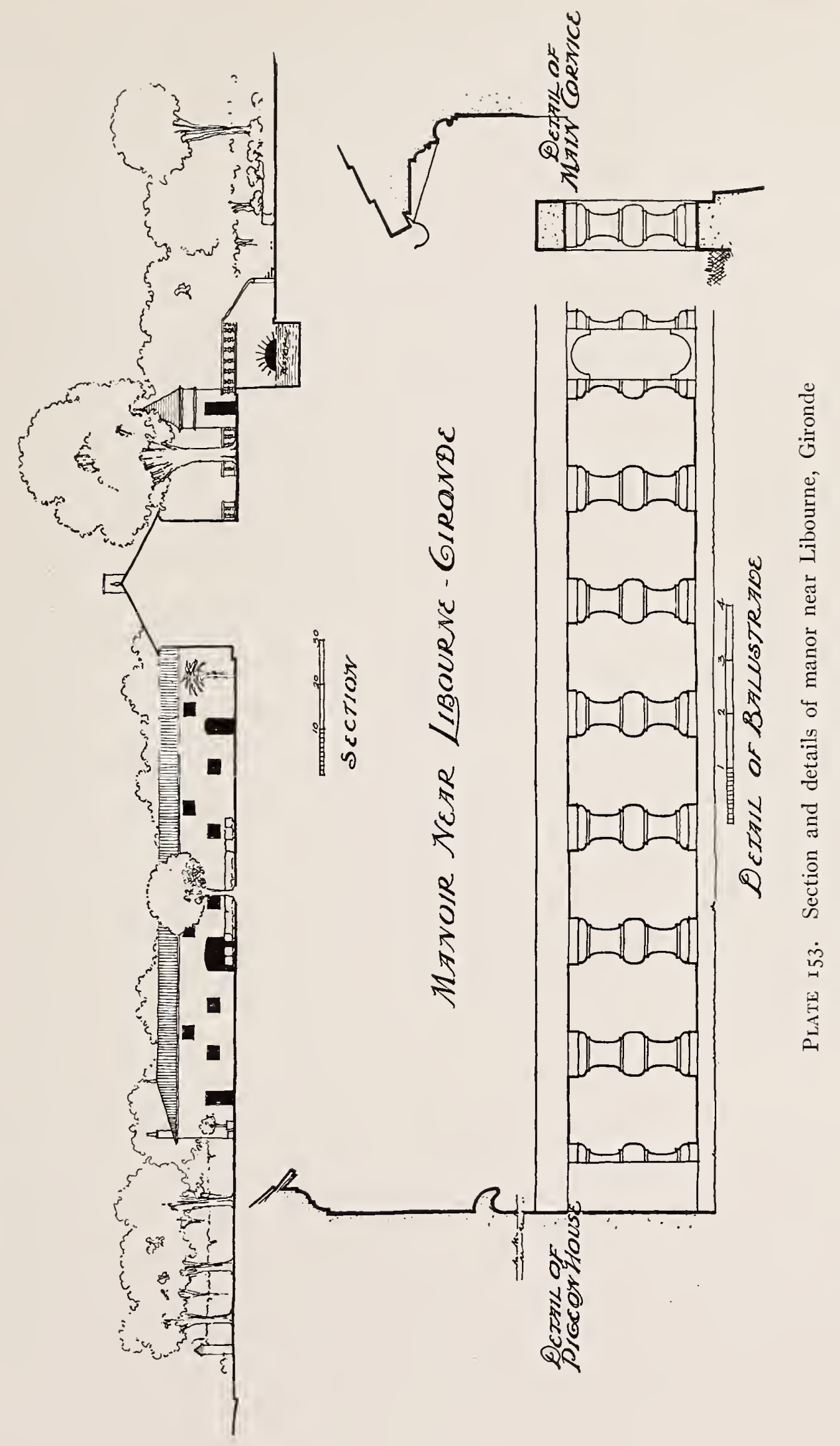





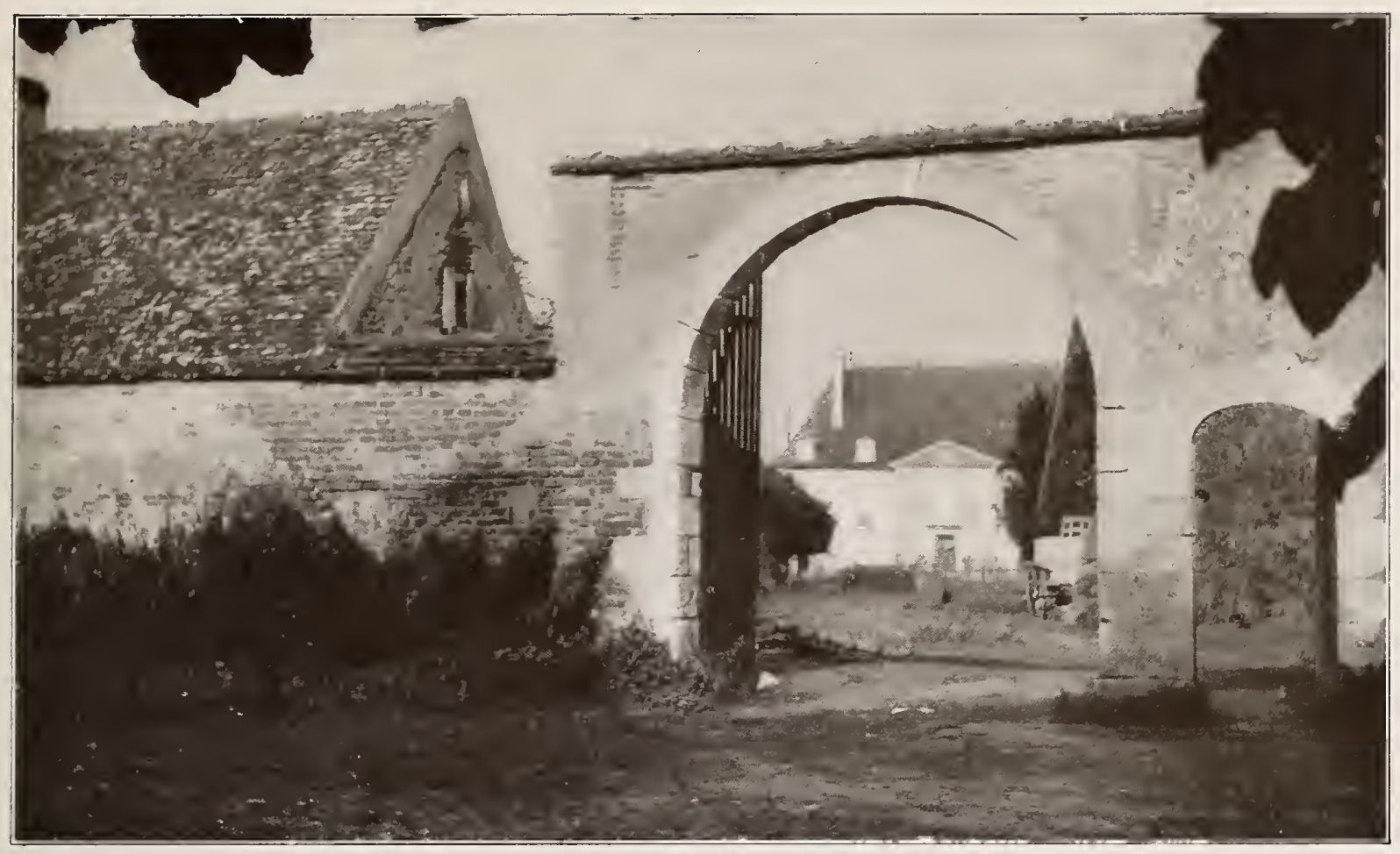

Plate 554. Farm entrance, manor near Demigny, Saône-et-Loire

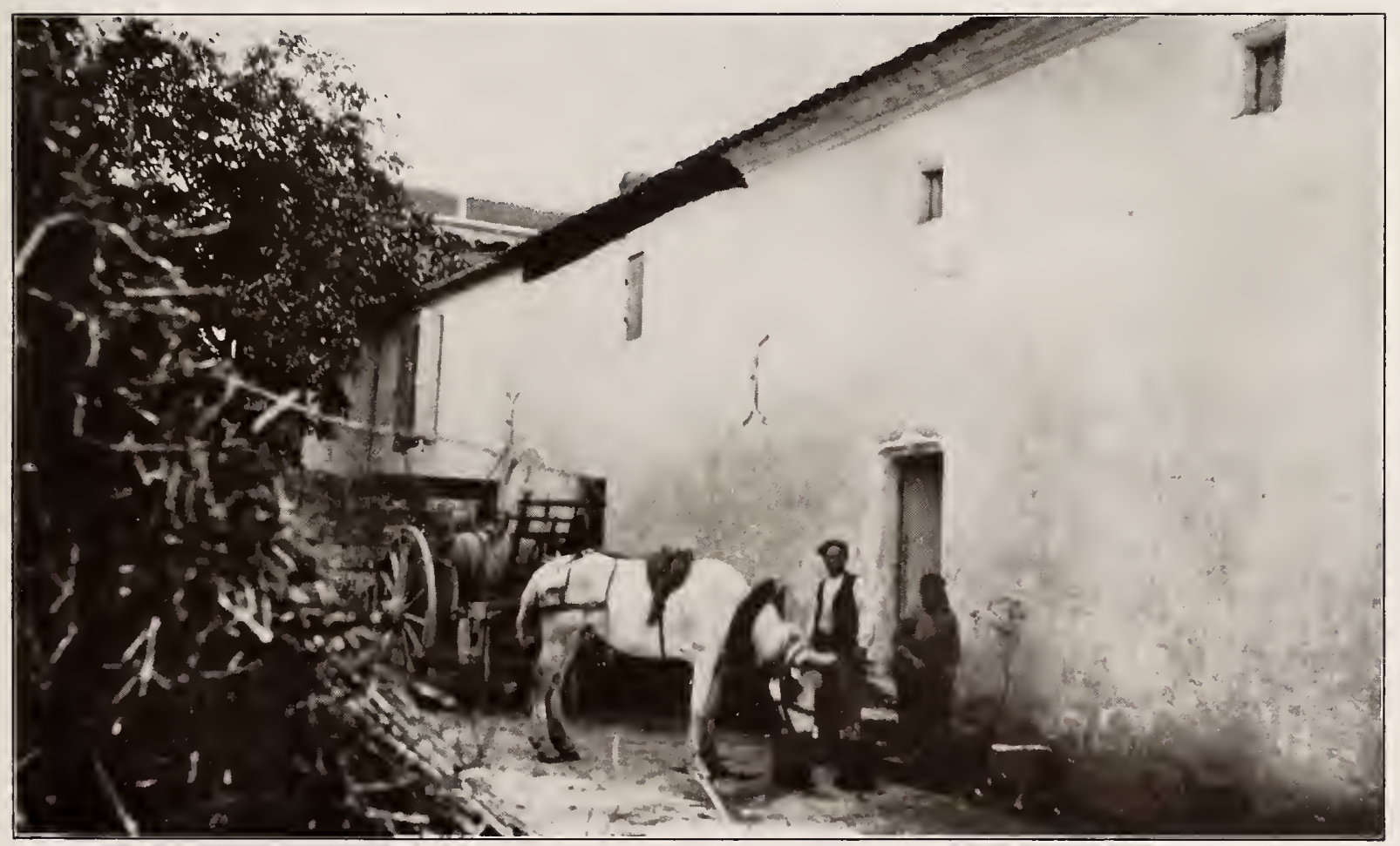

Plate ${ }^{5} 55$. Stable near St. Emilion, Gironde 



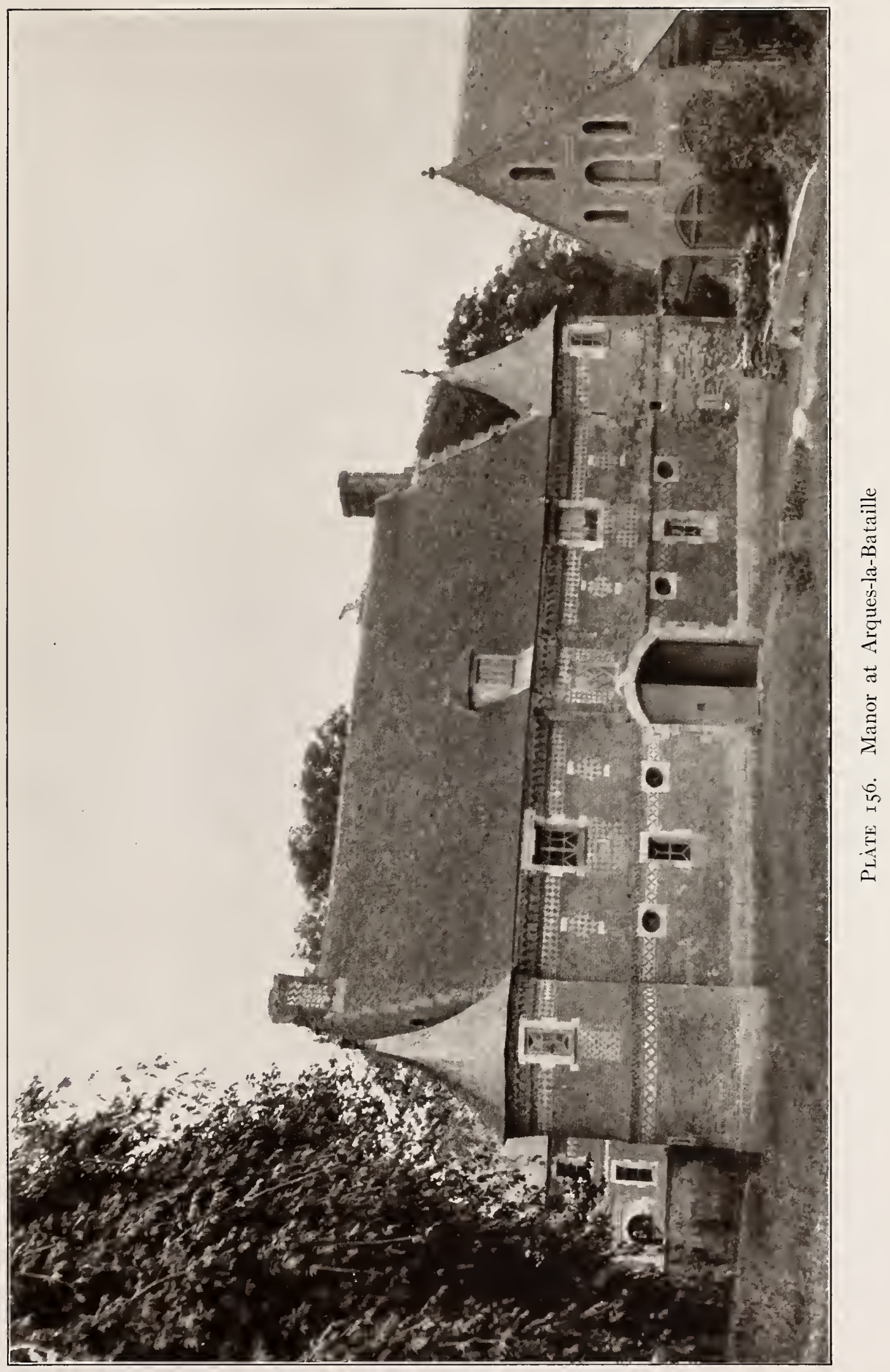





\section{E T A I L S}

Among the miscellaneous details which present the most interest are gateways, of which there are found chiefly two varieties - the large gateway or pavillion which usually forms the entrance to the farmyard or court of a manor or large farm group, and the smaller garden gateway, not intended for the passage of vehicles. There are included several examples of each. Plates I69, I73, and I74 are examples of the entrances to farmyard or court, and Plates I68, I70, I80, and I 8 I are good examples of the types of garden gates. The bold moulding in the gate illustrated on Plate $I 80$ is in harmony with the adjacent rubble wall, and the split pediment, undoubtedly for planting, is of interest. We were very much pleased with the discovery of the thatched farm entrance on Plates I57 and I74, which is such an unusual and altogether charming combination. The gateway shown on Plate I73 illustrates the horizontal striped treatment of brick and stone, typical of Normandy. The massive stone gate-posts forming the entrance to the court of Château St. Georges on Plate I83, tremendous in scale and of bold and unusual detail, have an impressiveness that a designer of to-day would find hard to originate.

Plate I68, a carved stone Renaissance gateway, suggestive of Italian design, represents the more elaborate garden design, while the gates on Plates I8I and $\mathbf{1} 82$ illustrate a bolder, simpler style of less pretentious gardens. There are several excellent gateways on the terraces of Château Brécy, the one shown on Plate I 70 being at the end of the ascending terraces on axis with the house and opening out from the uppermost garden wall to the farm lands beyond.

Besides the gateways, interesting details are doorways, pigeon-houses, wellheads, and such occasional details as the balustrade at Billom with its use of masques and crisp balusters. The pigeon-house seems to have been an almost indispensable part of a farm group, being invariably a picturesque feature, distinct by itself of each farm court. The circular pigeon-house at La Grande Verrière on Plate $15^{8}$ has an unusual curved flight of stone steps supported by a stone column, while the one at the Manoir Duval shows a rather elaborate brick corbelled cornice and stocky solid proportion. Both of these are circular in plan, one of stucco and the other of brick, while Plate r6o shows an example of an octagonal cut stone tower, with a conical tile roof, which changes again to an octagonal-shaped base below a round cupola. 



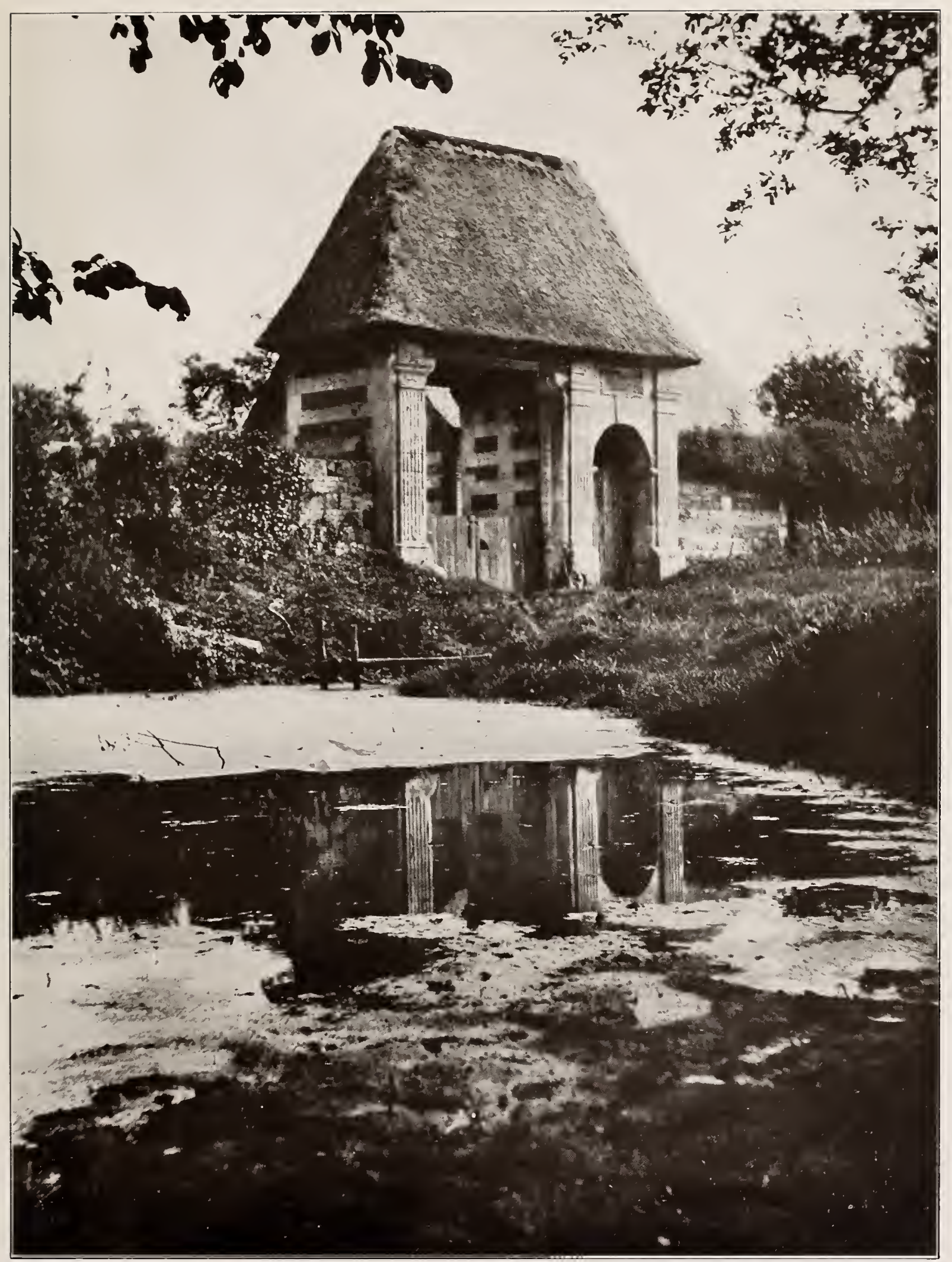

Plate 157. Farm-gate near La Remuée, Seine-Inférieure 


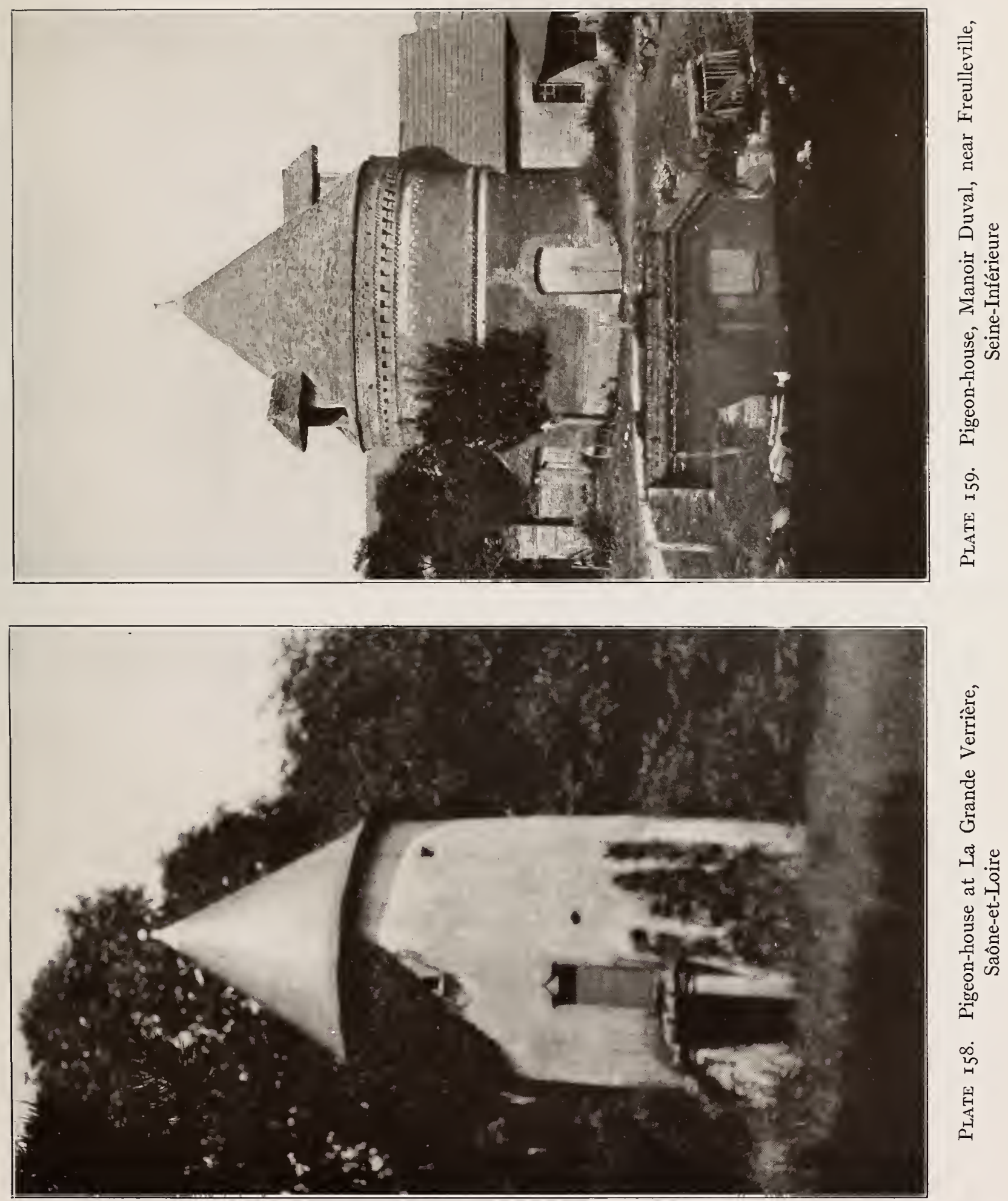

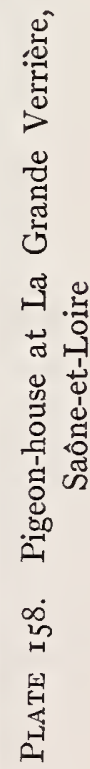





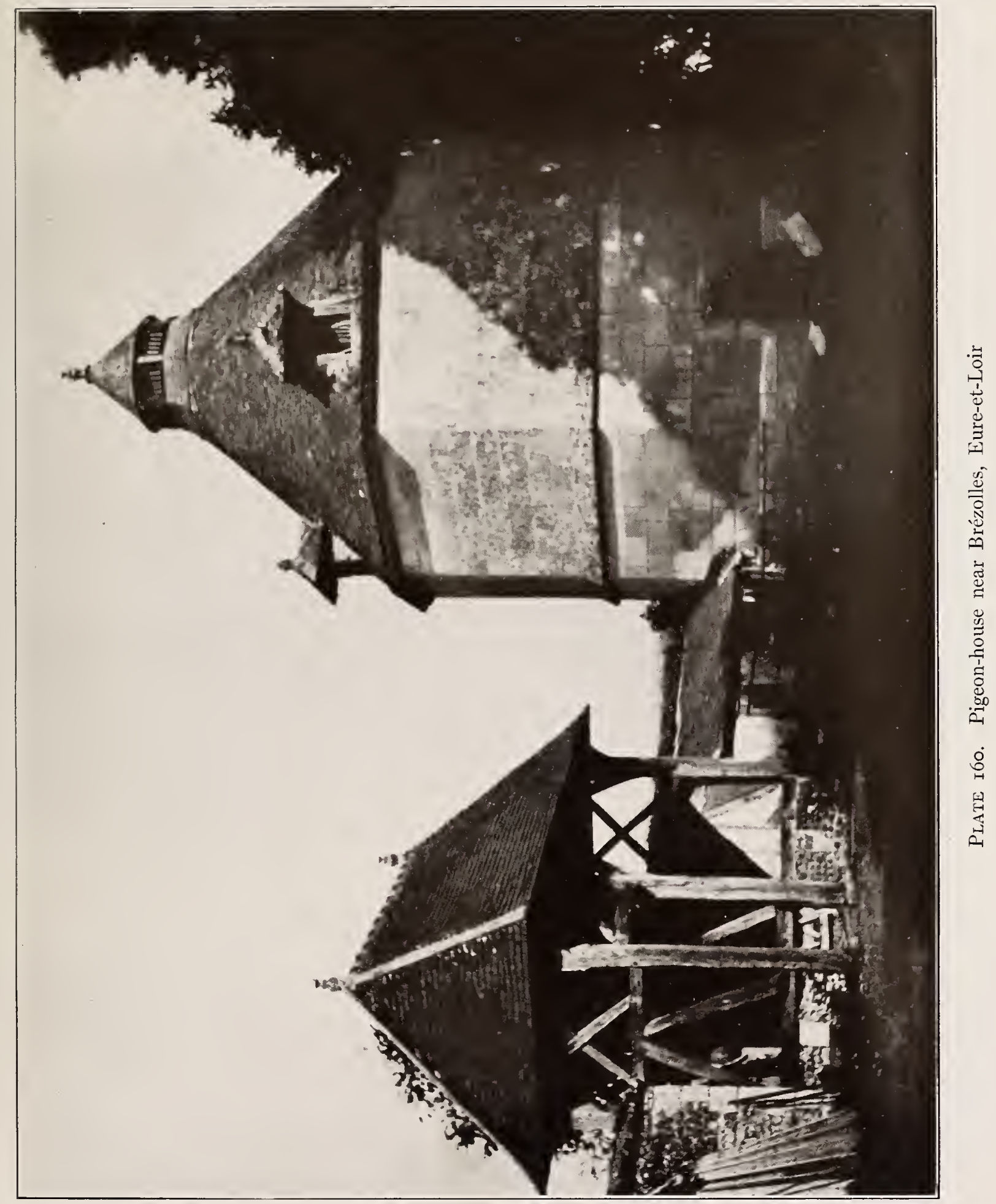





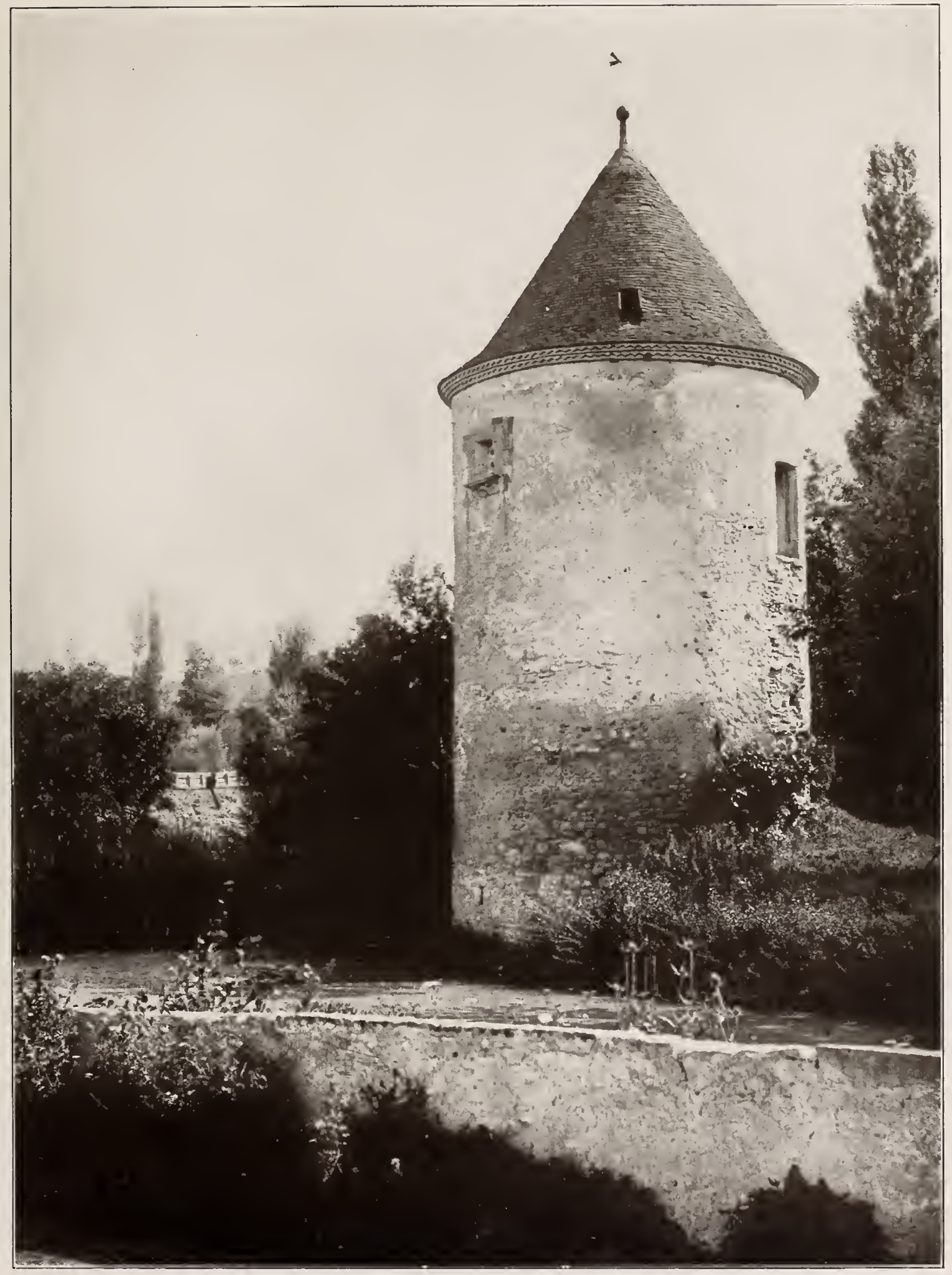

Plate i6r. Pigeon-house near Chartres 



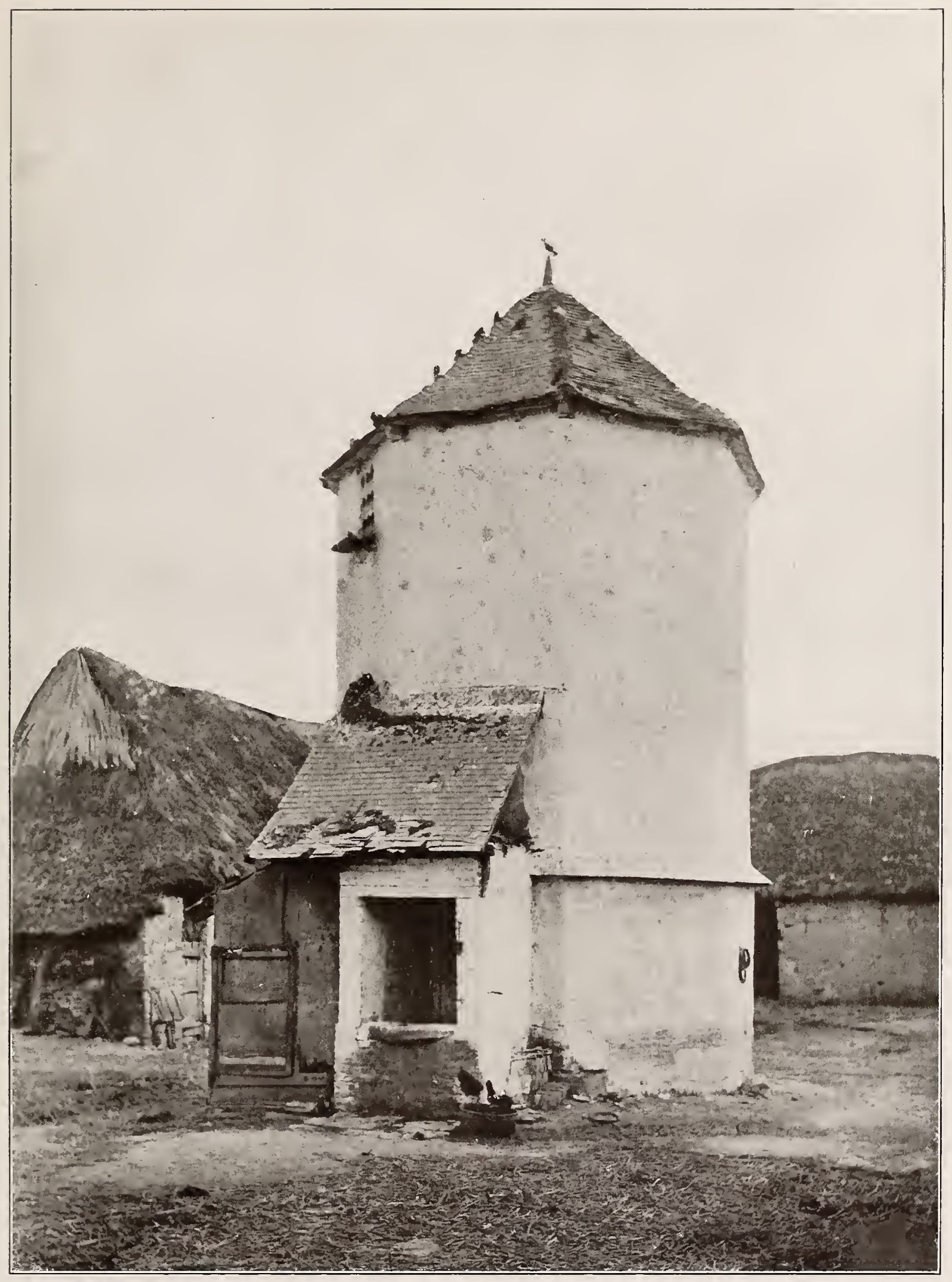

Plate 162. An octagonal pigeon-house 



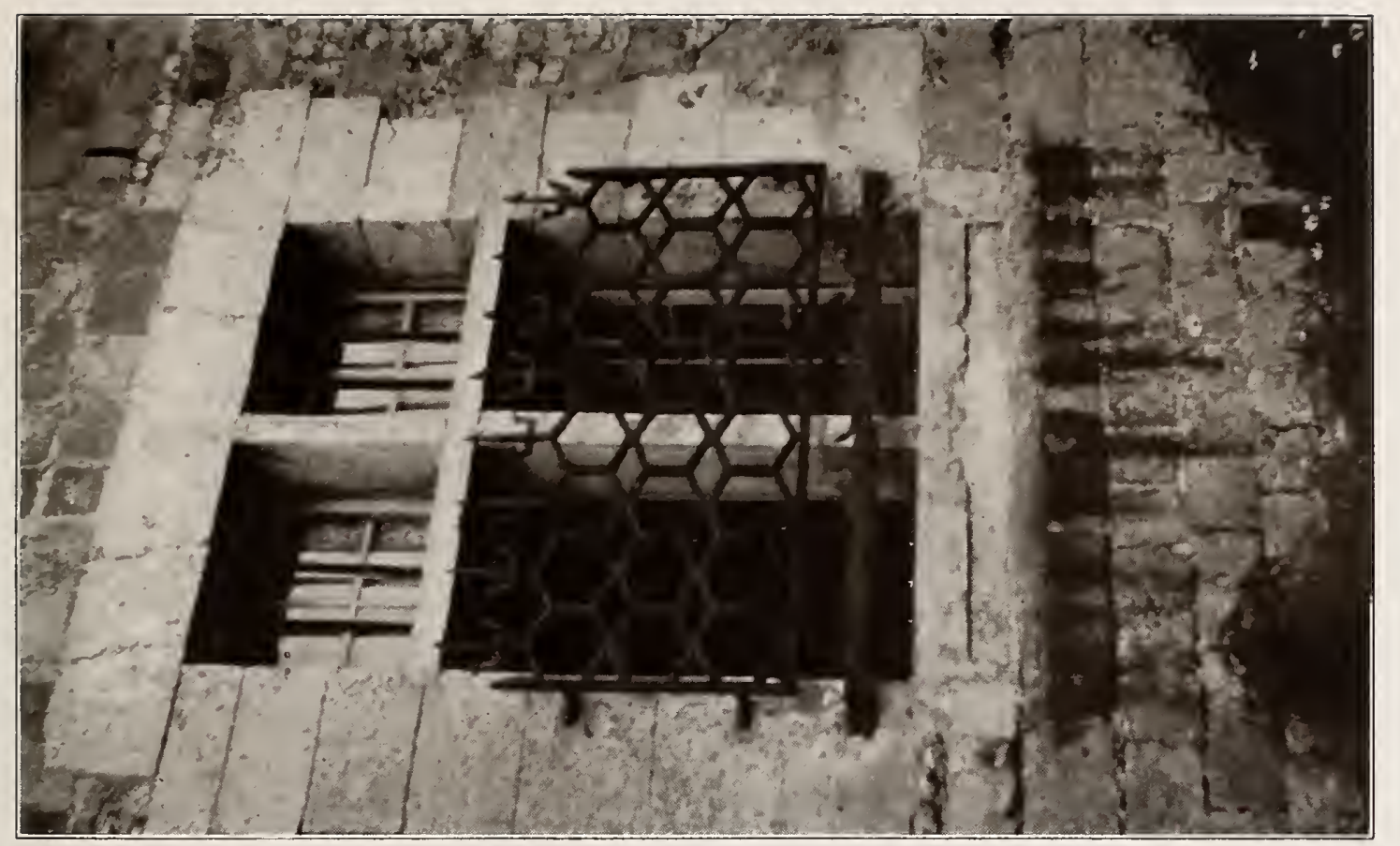

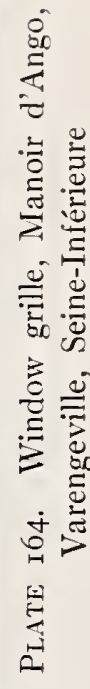

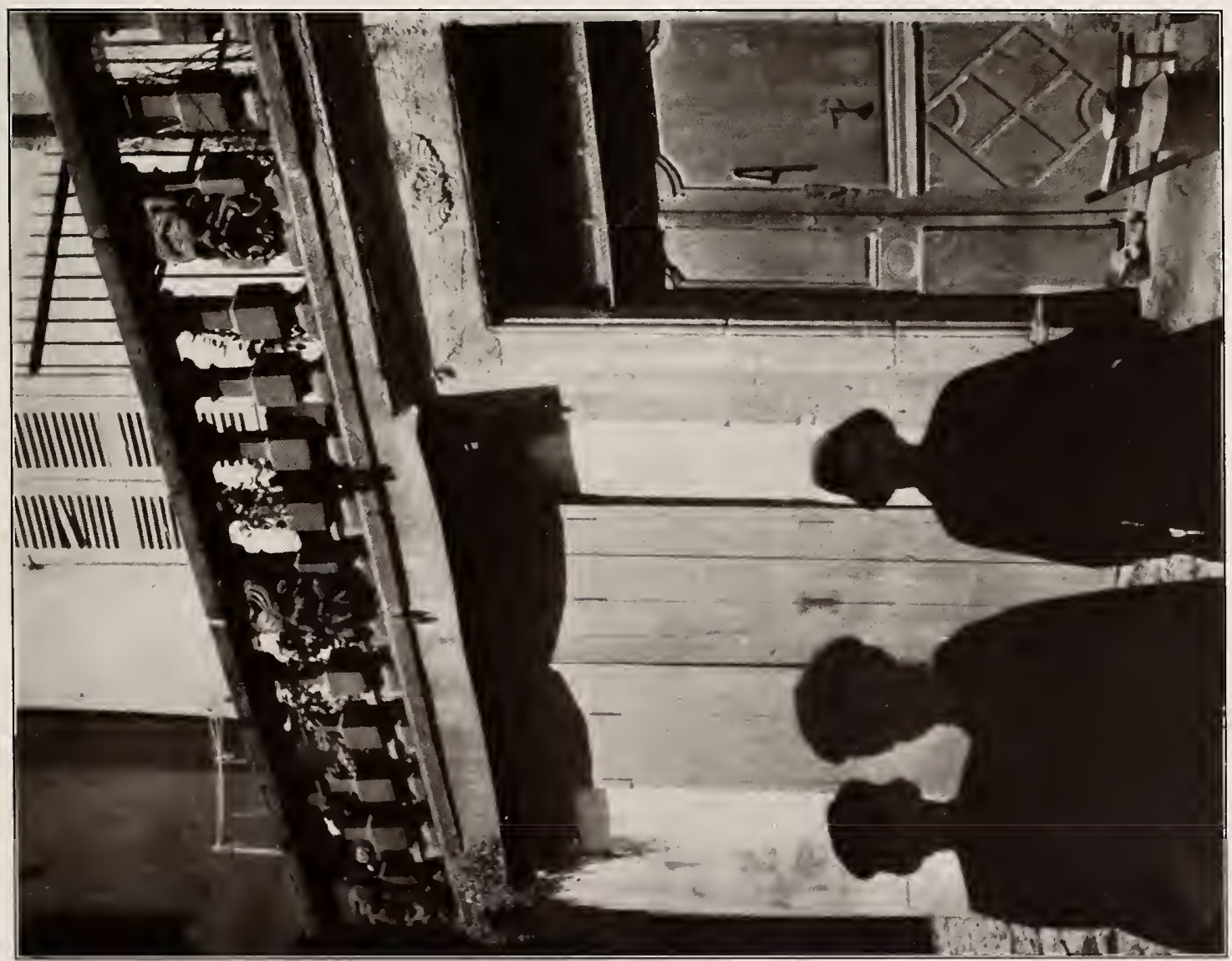

艺 



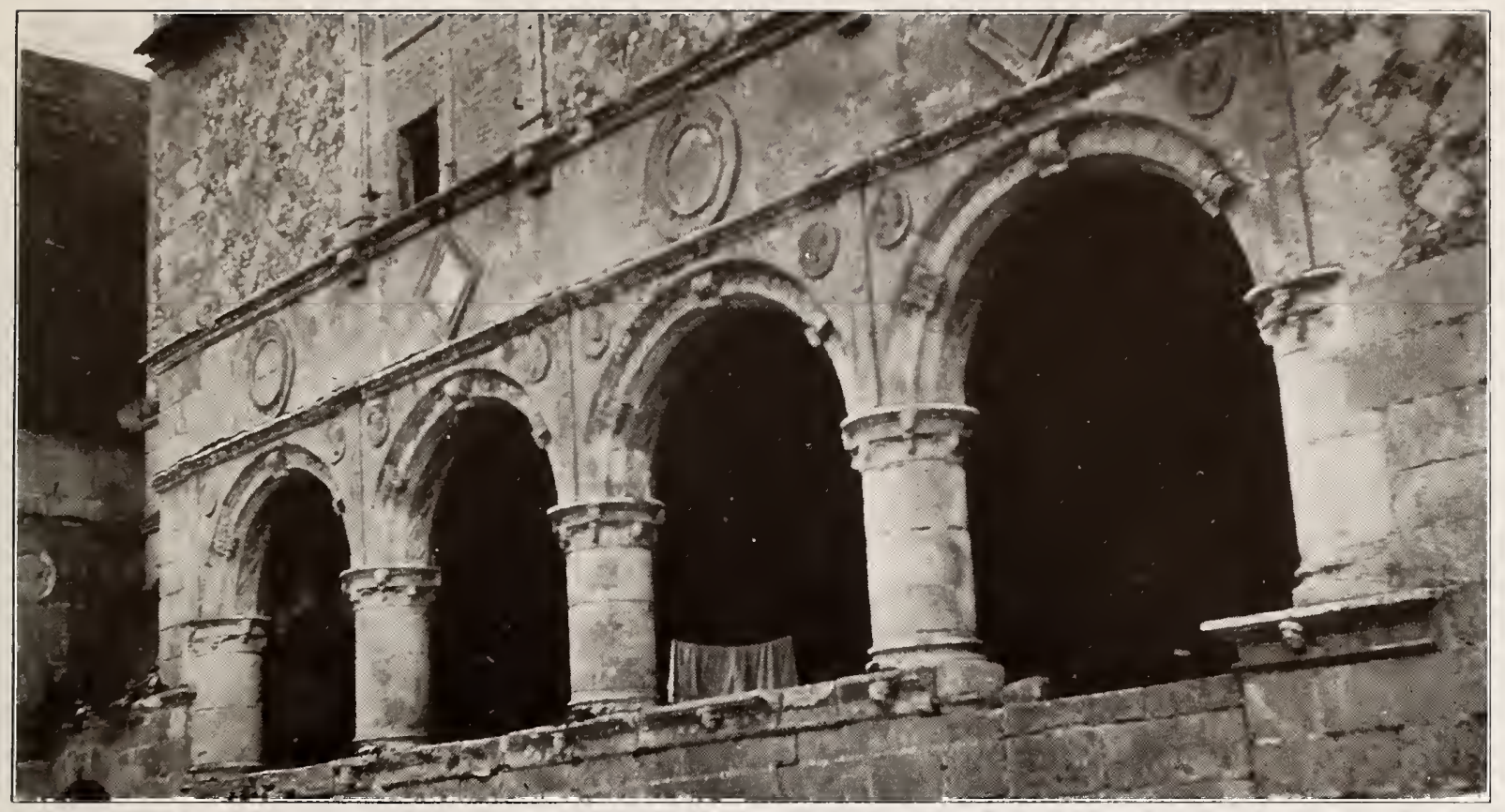

Plate 165. Loggia, Manoir d'Ango, Varengeville, Seine Inférieure

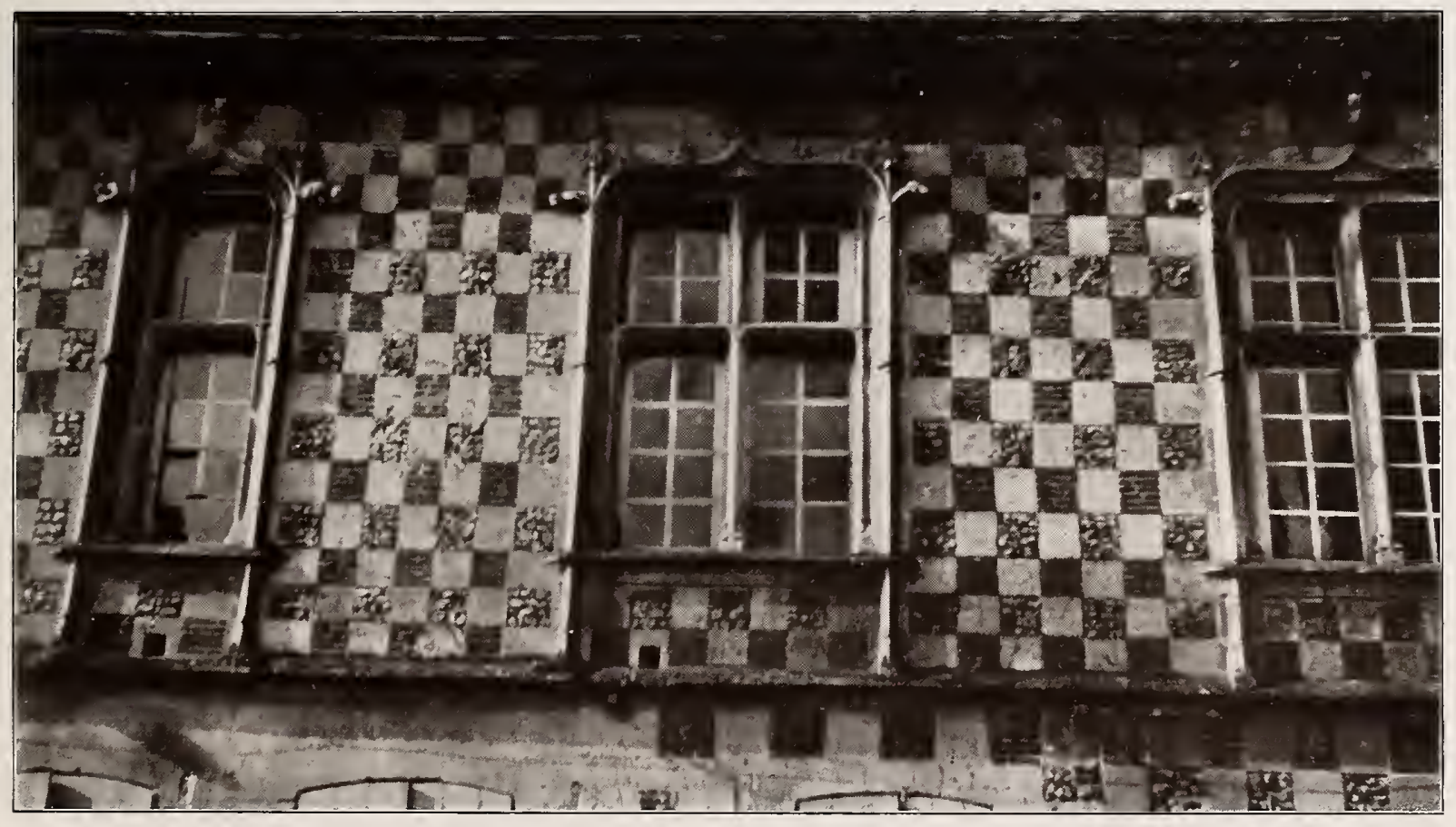

Plate r66. Detail, house at Verneuil, Eure 



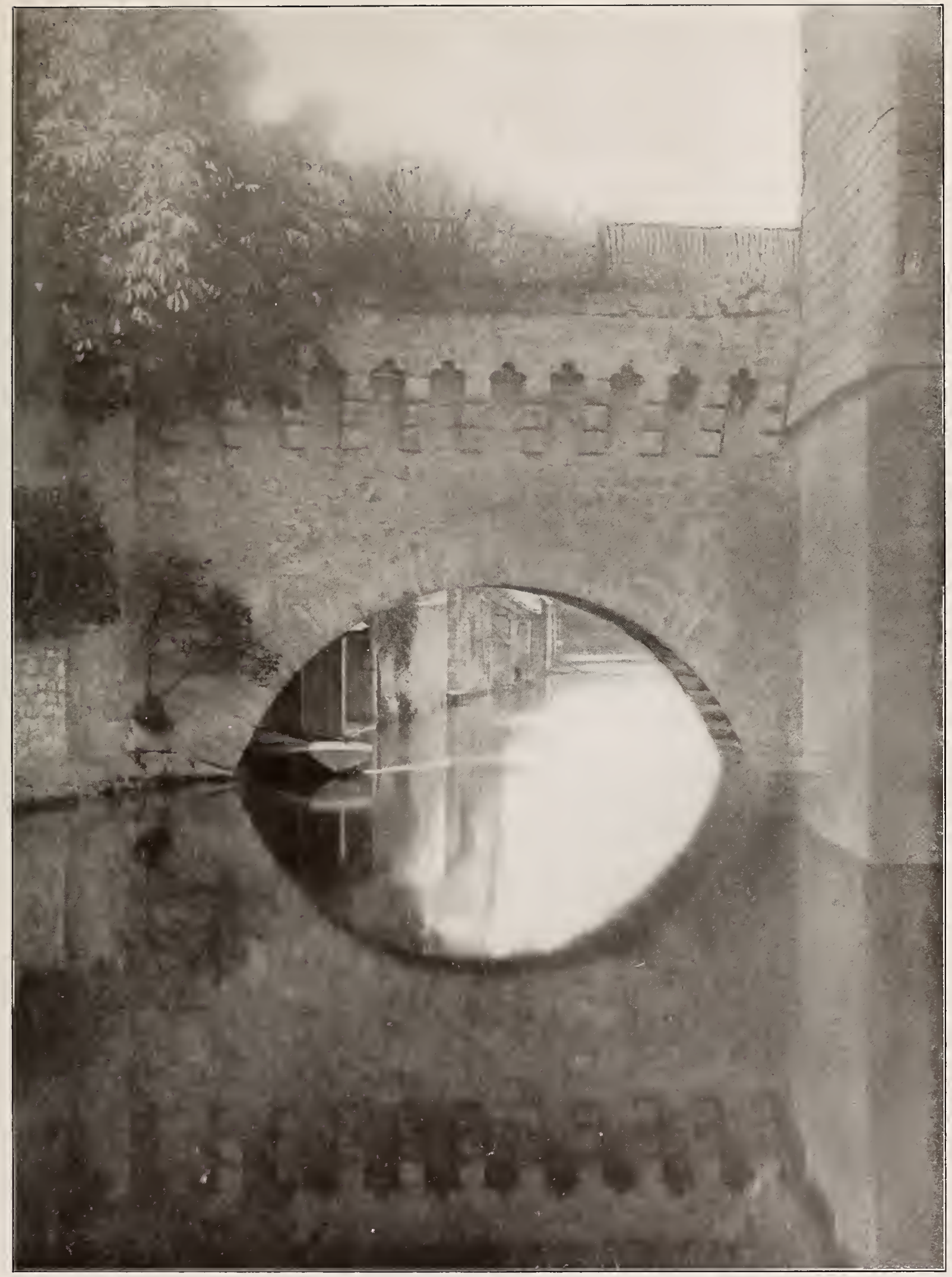

Plate 167. Bridge at Vendôme, Loir-et-Cher

$25 \mathrm{I}$ 



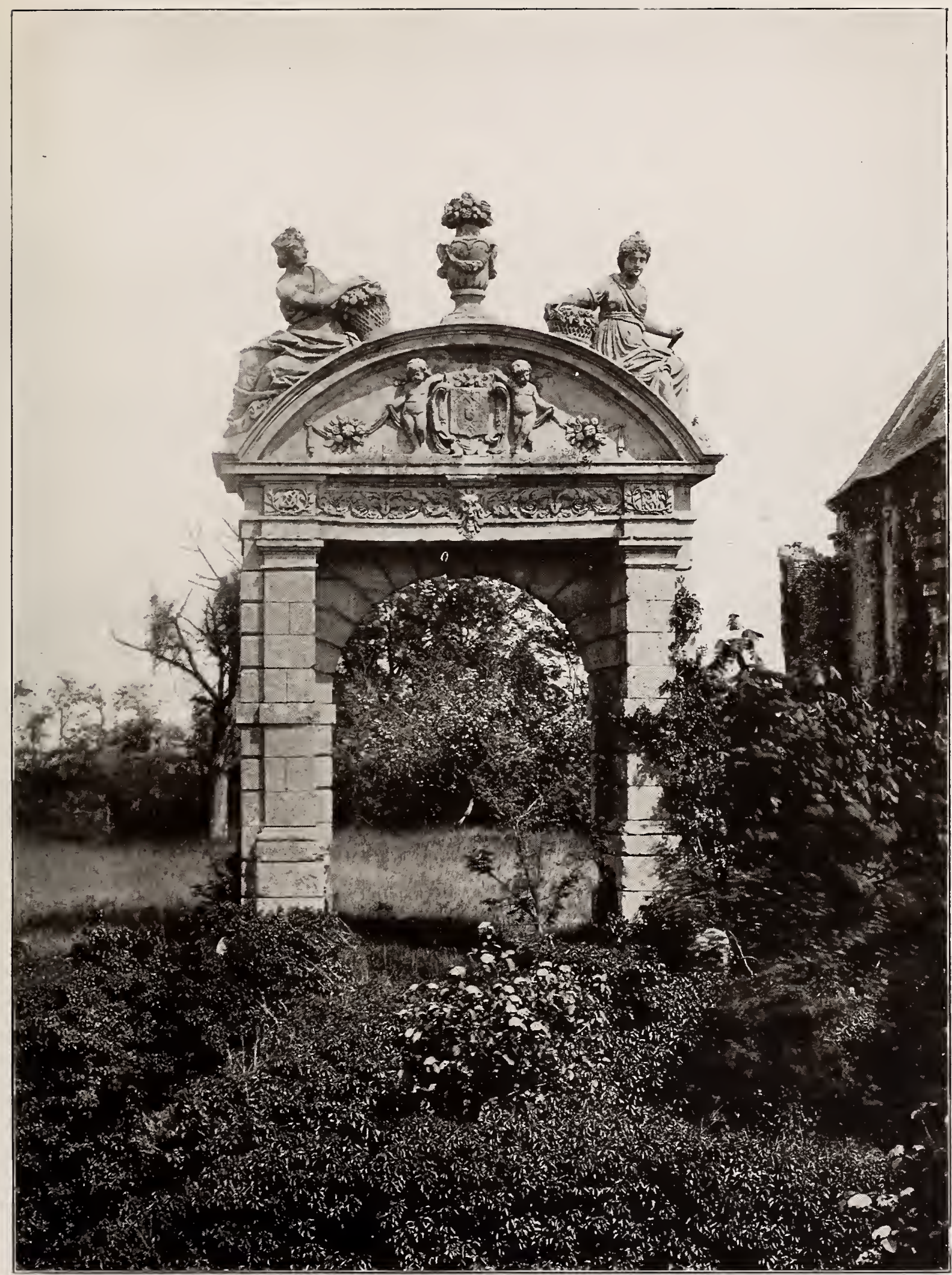

Plate i68. Garden-gate, Château de Sorel, Dreux, Eure 



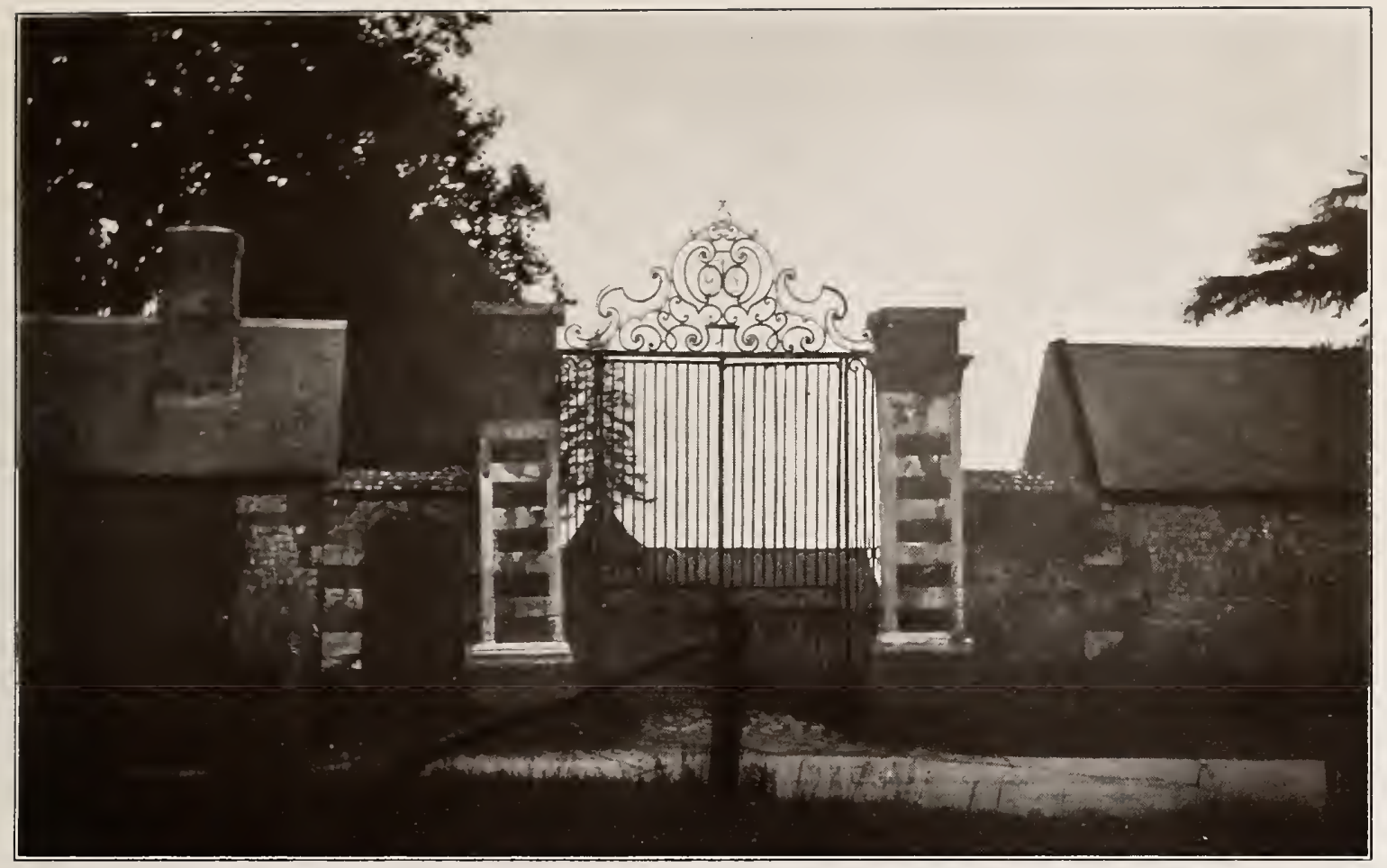

PLATE i69. Farm gate near St. Jean-de-Follerville, Seine-Inférieure

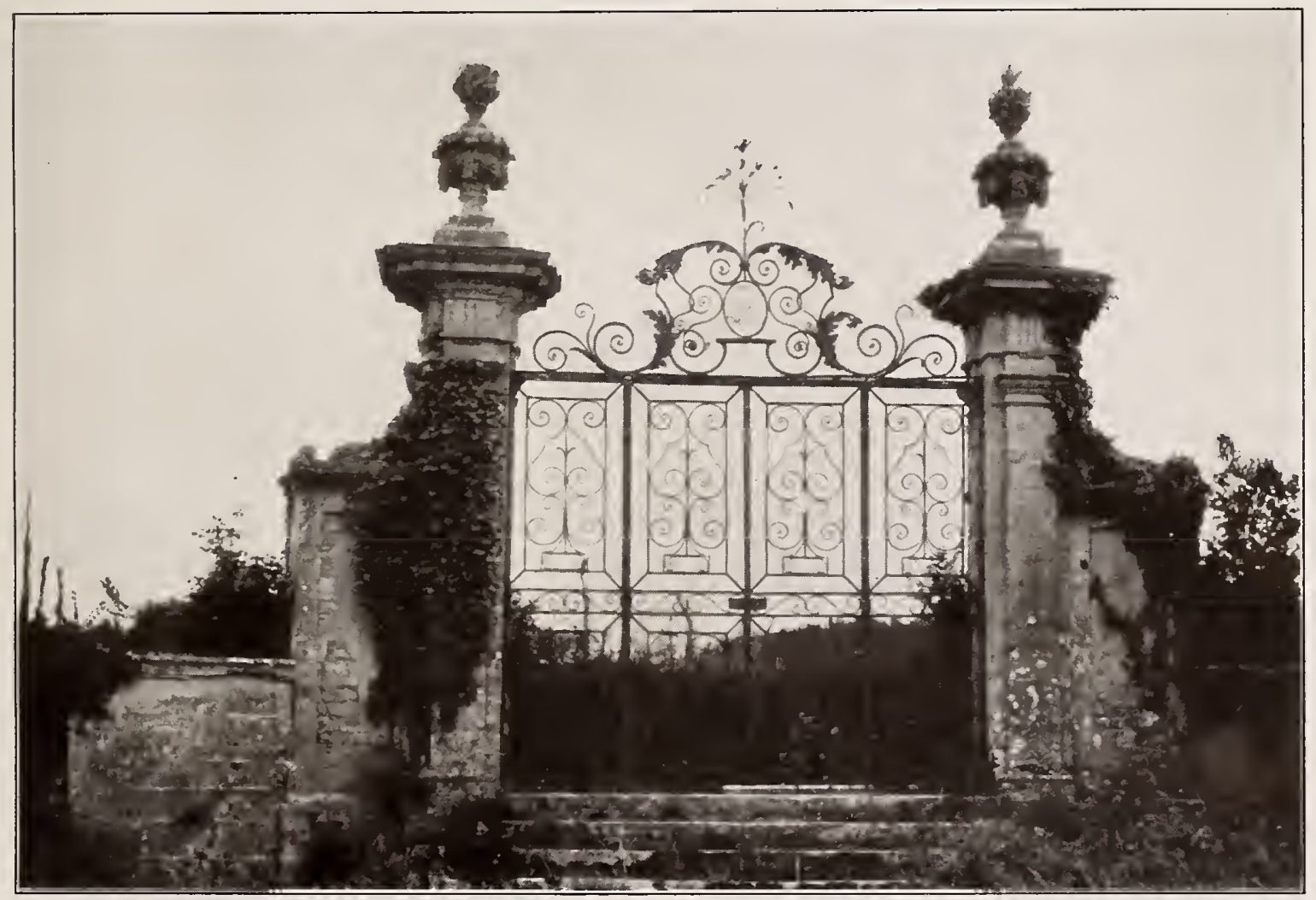

Plate I70. Gate from garden to farm, Château de Brécy, near Bayeux 



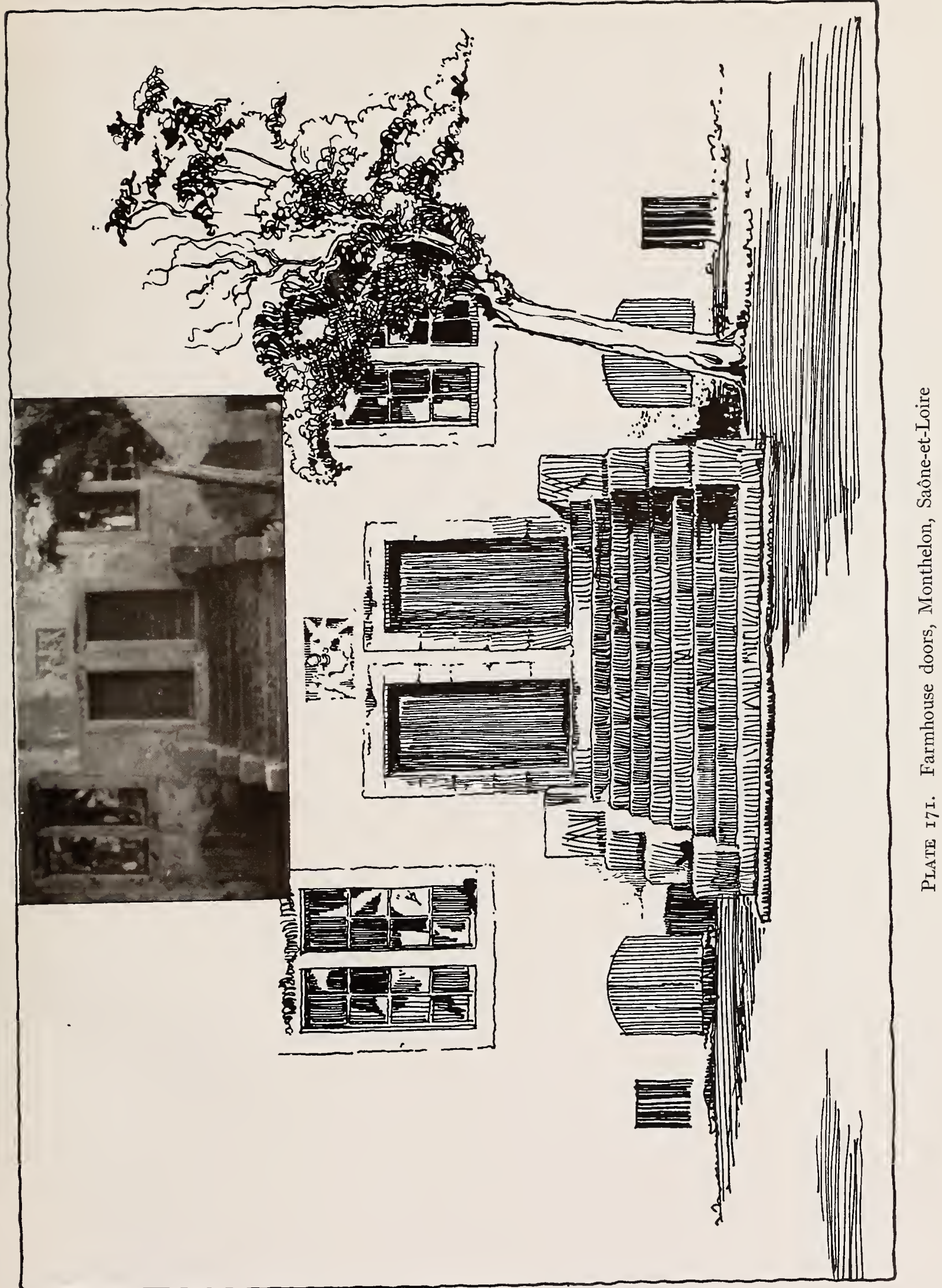





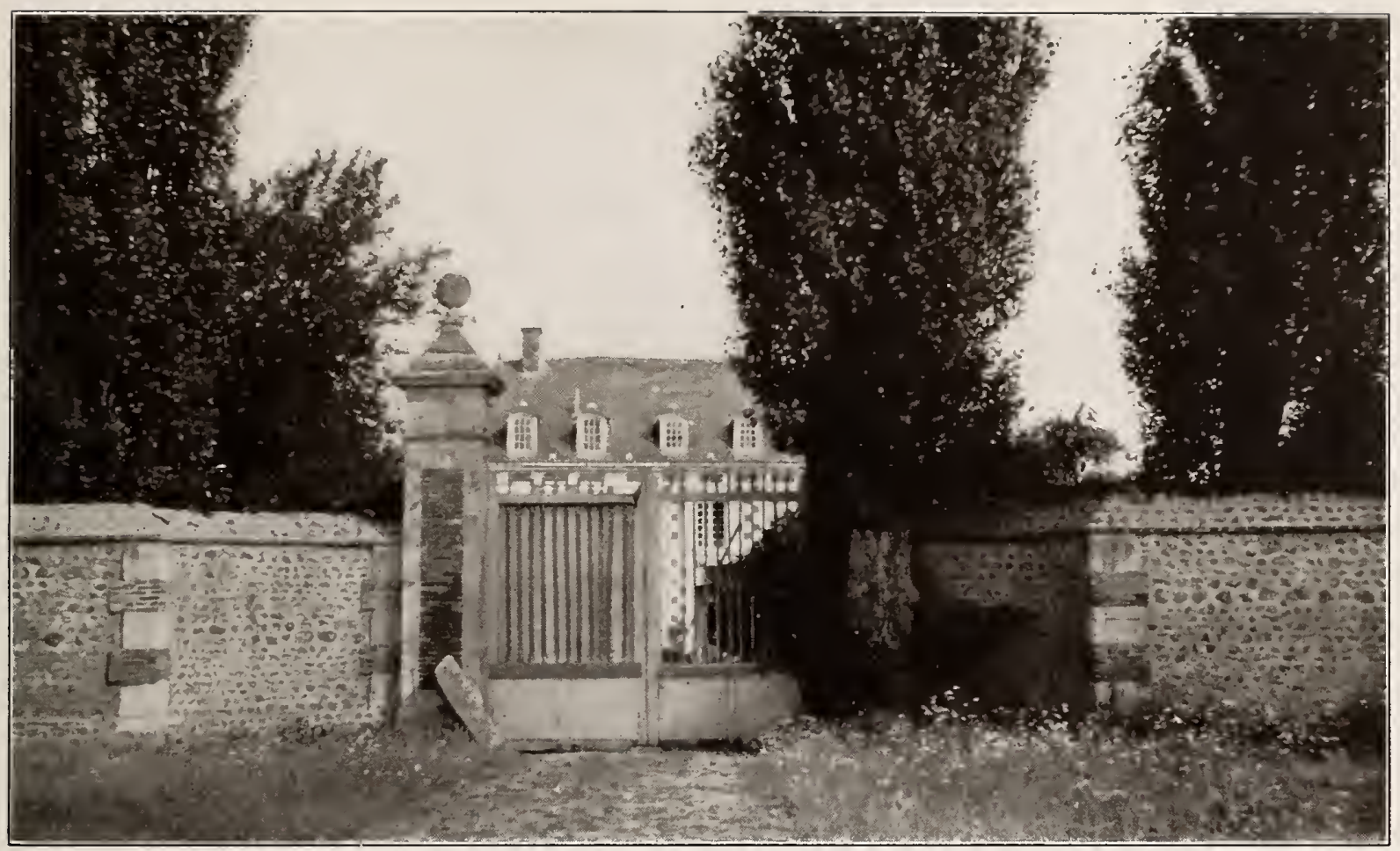

Plate i72. Gate near Evreux, Eure

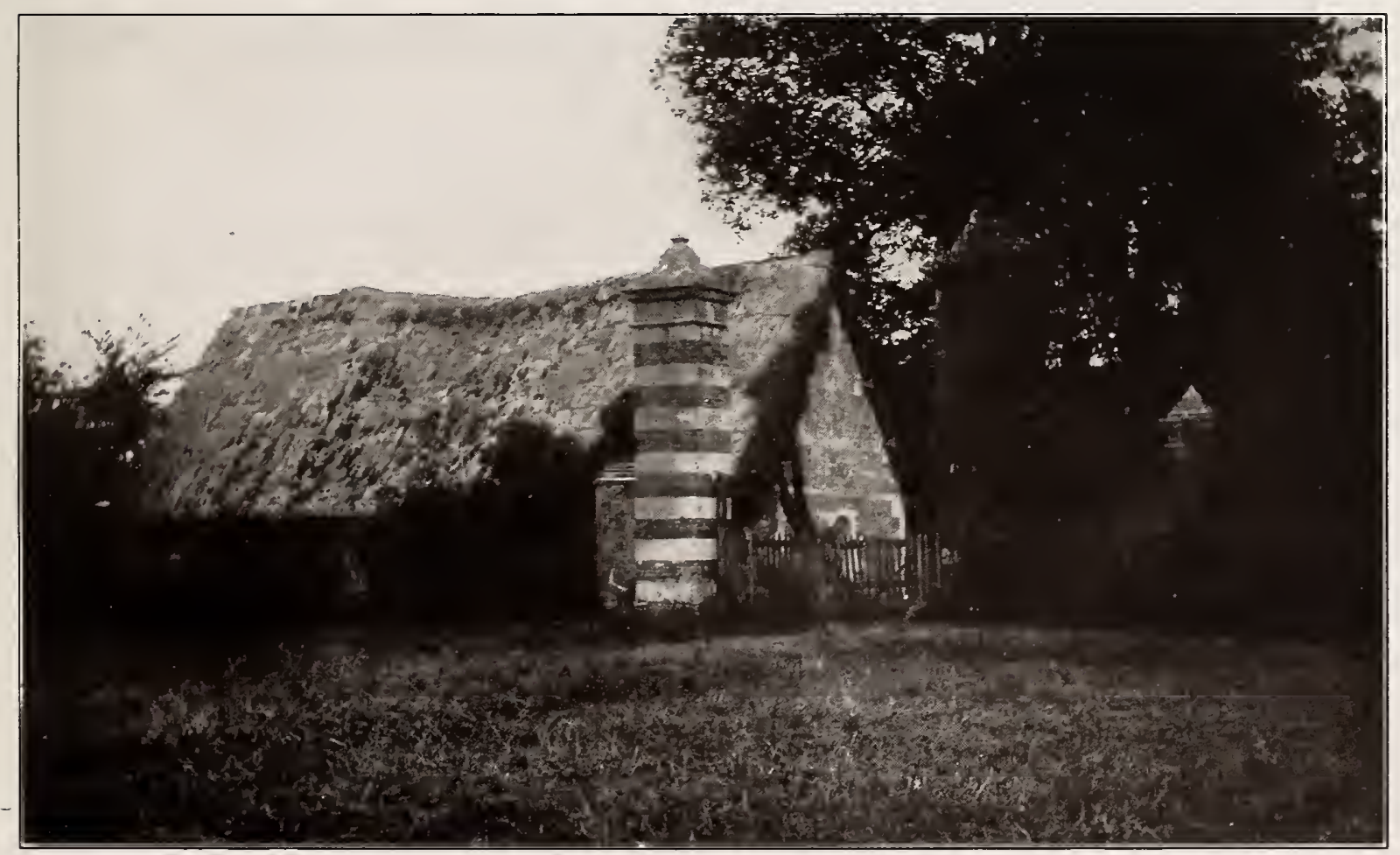

Plate i 73. Farm-gate near St. Jean-de-Follerville, Seine-Inférieure 



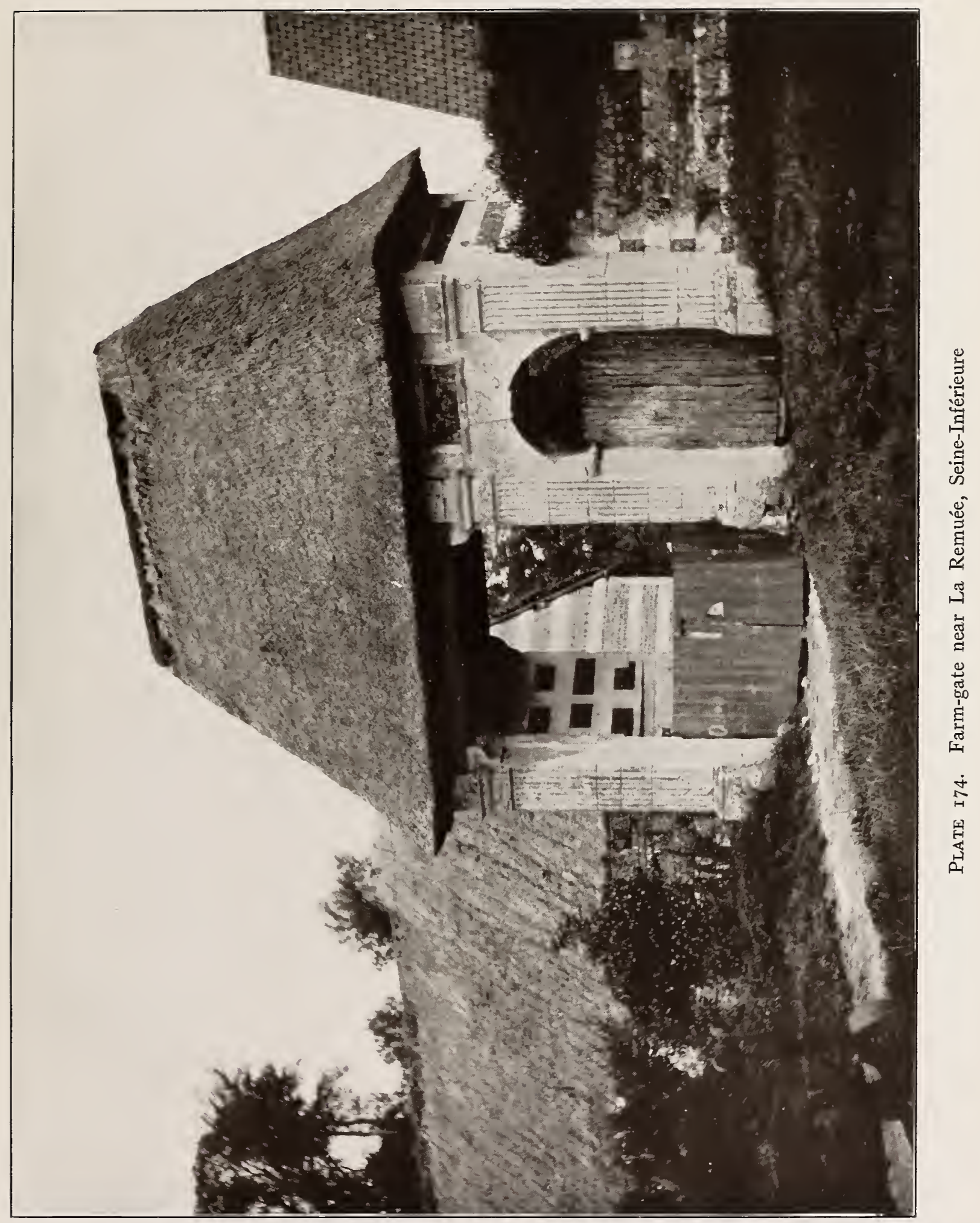





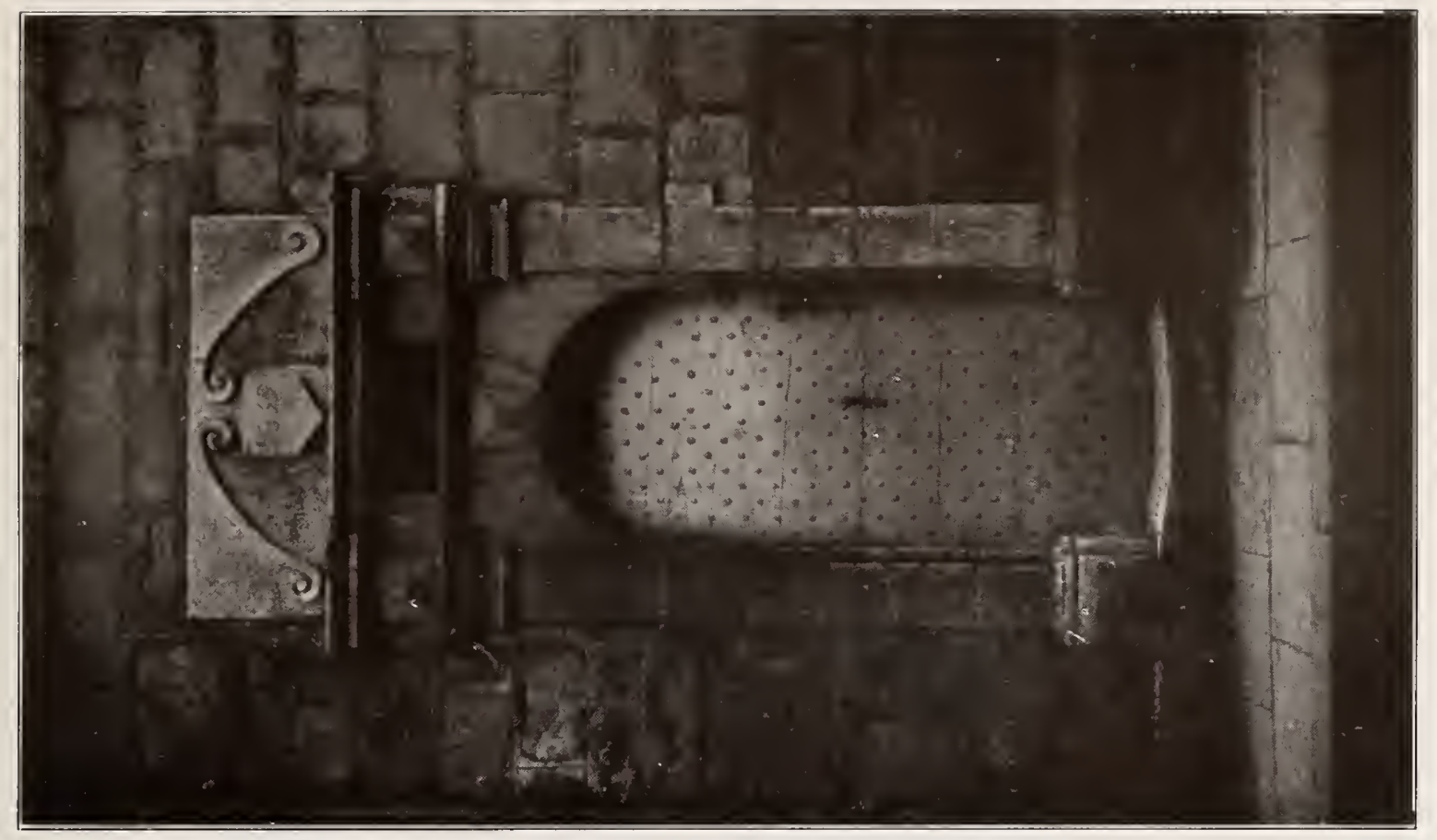

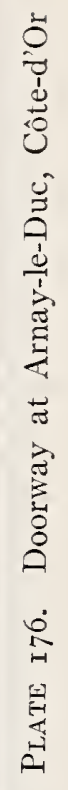

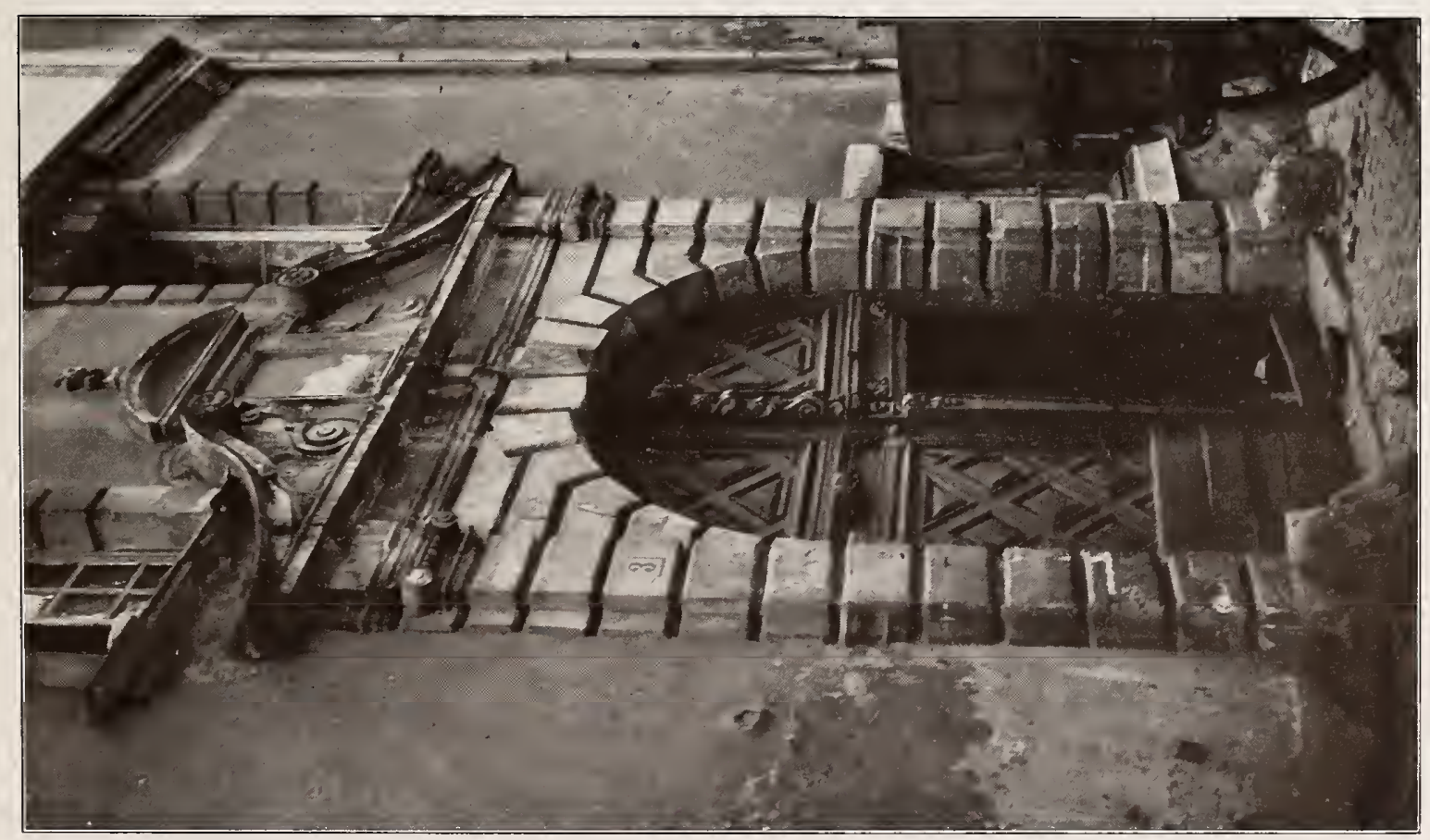

 



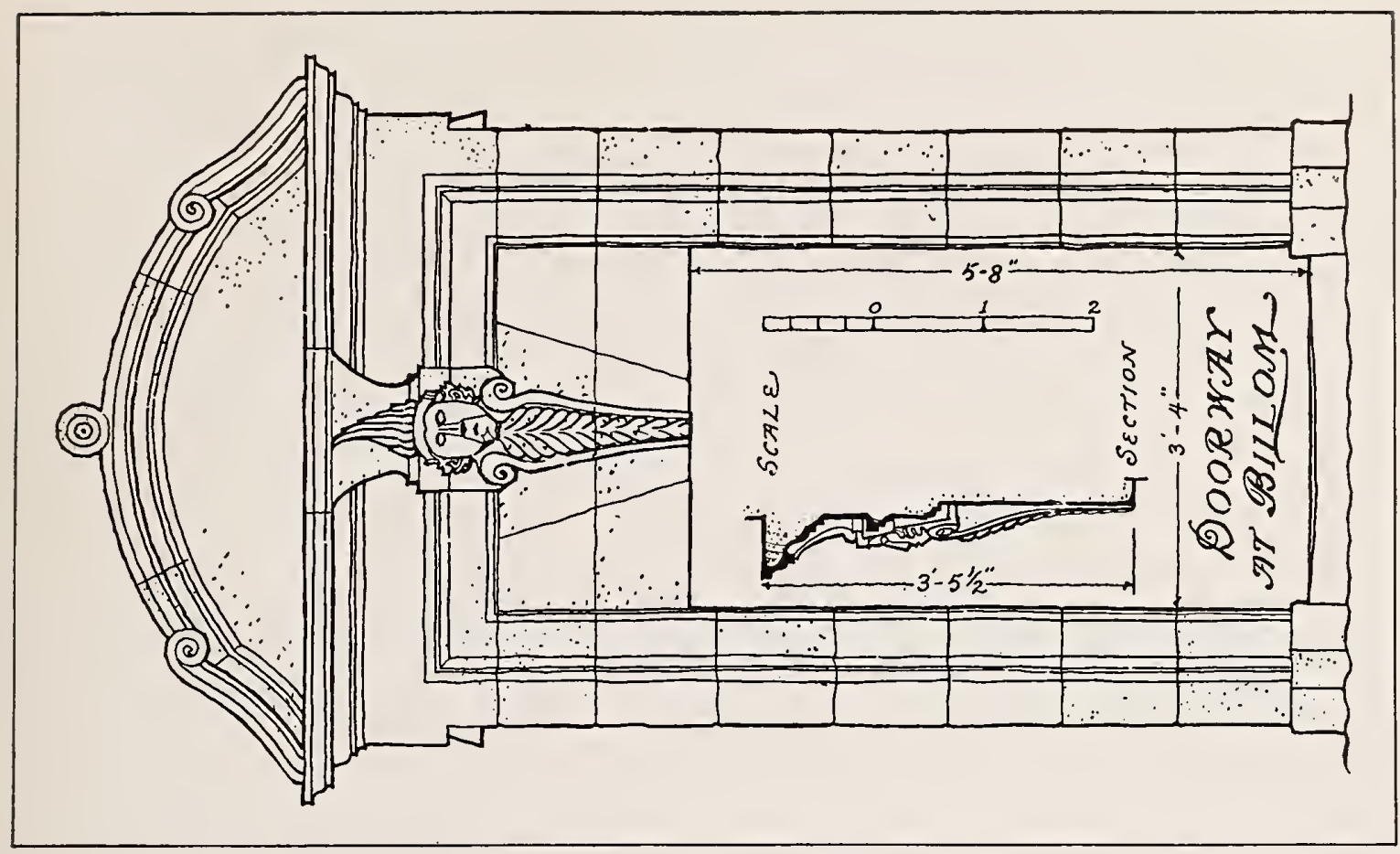

है

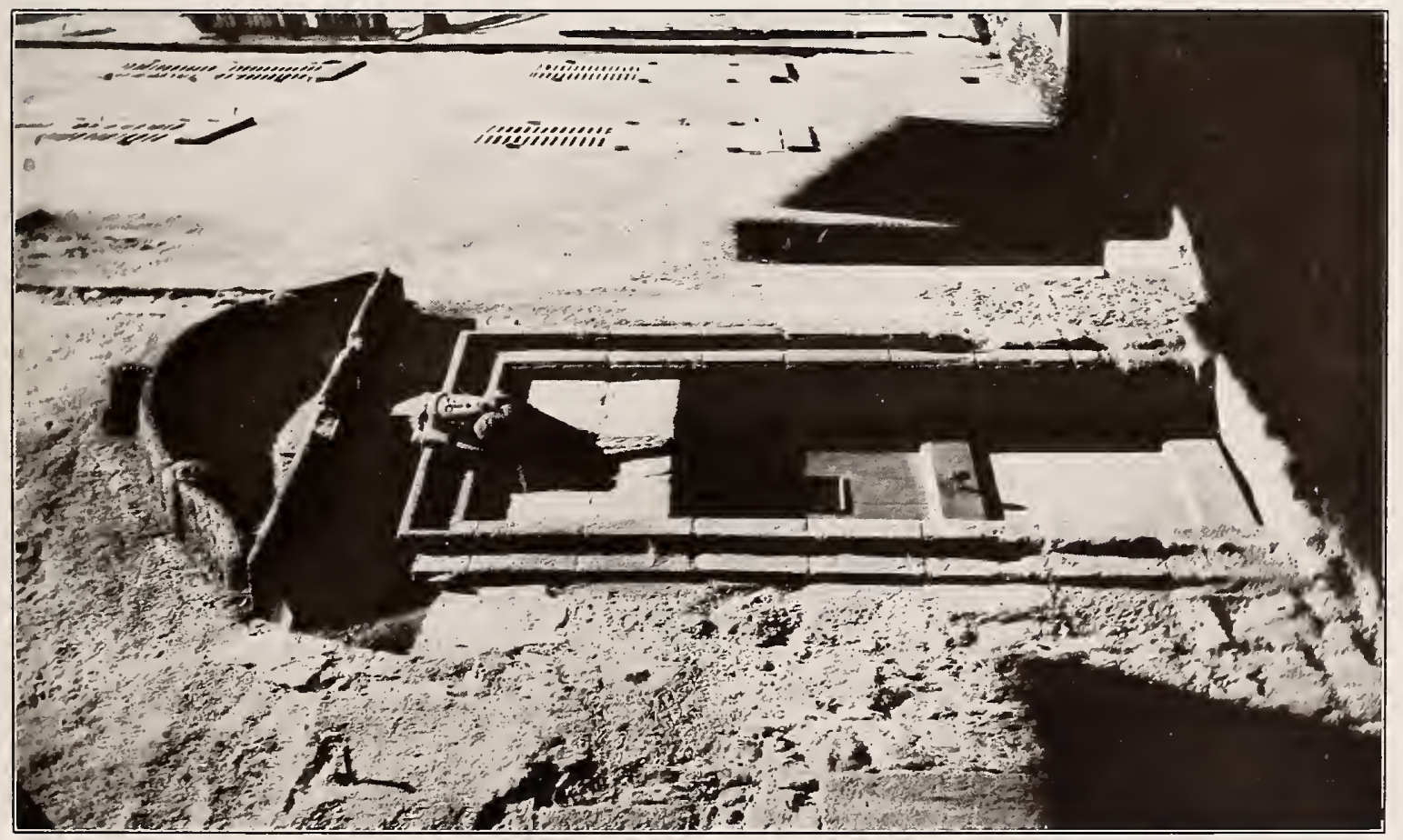





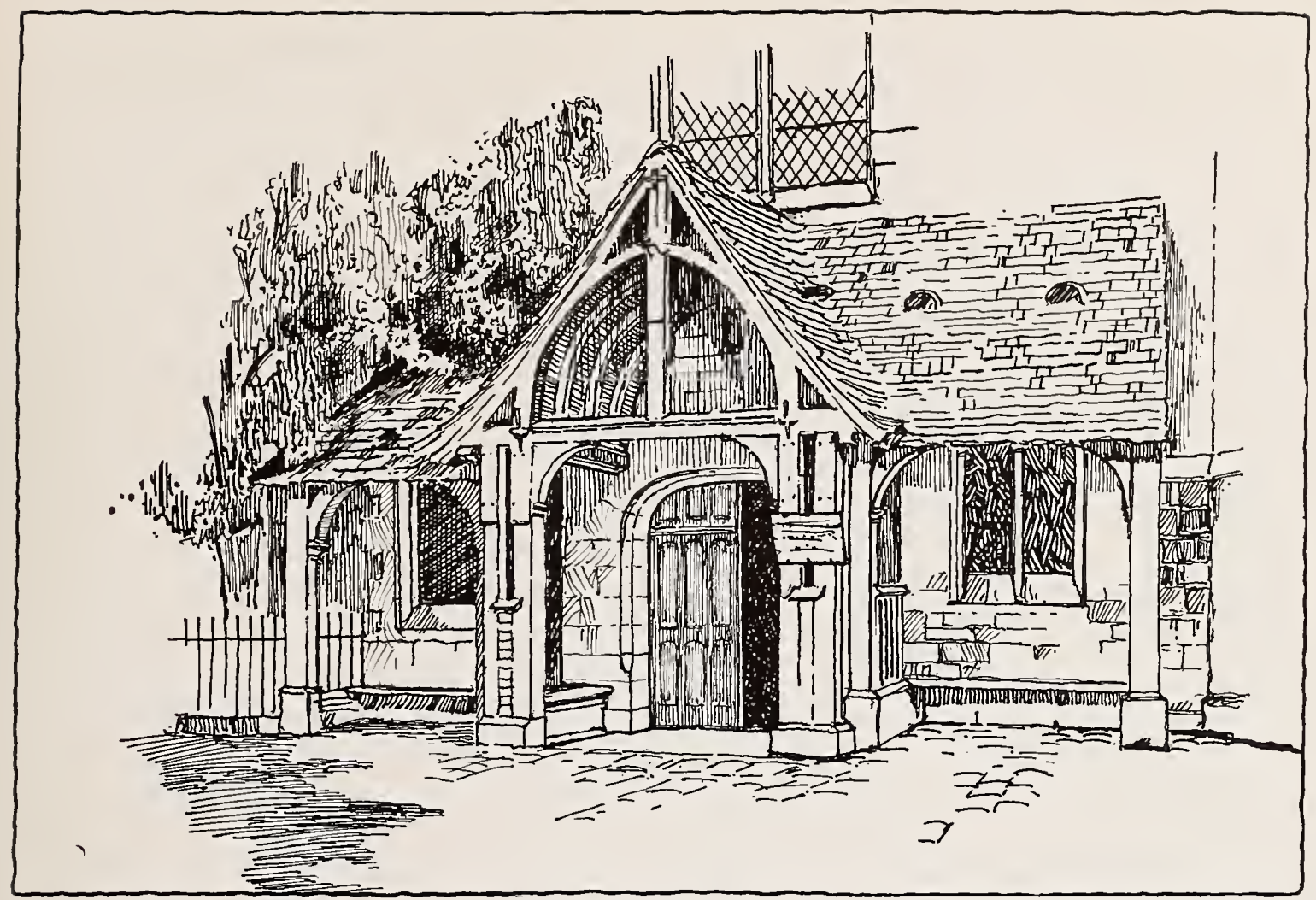

Plate 178. Church entrance at Honfleur, Seine-Inférieure

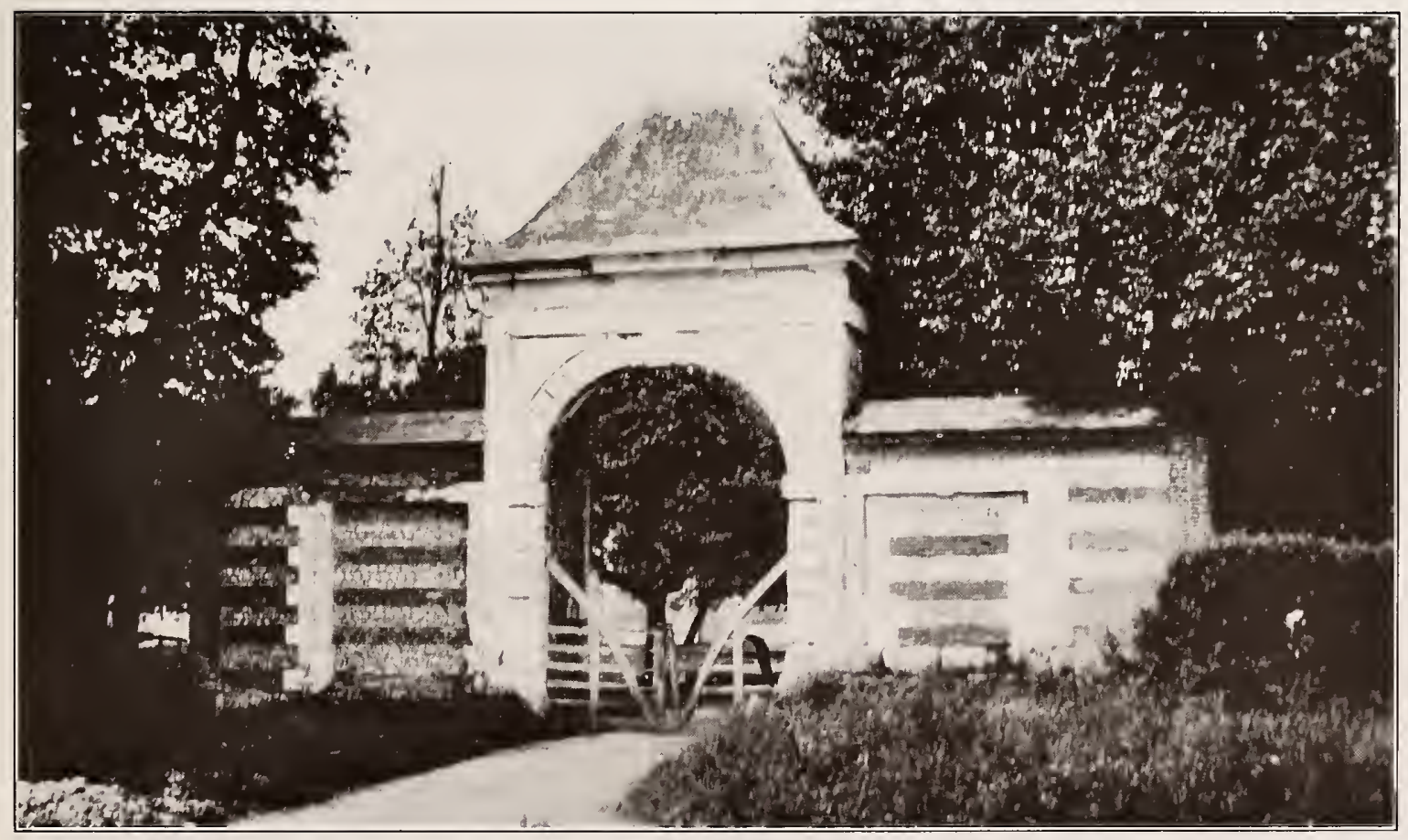

Plate i79. Farm entrance near Lintot, Seine-Inférieure 



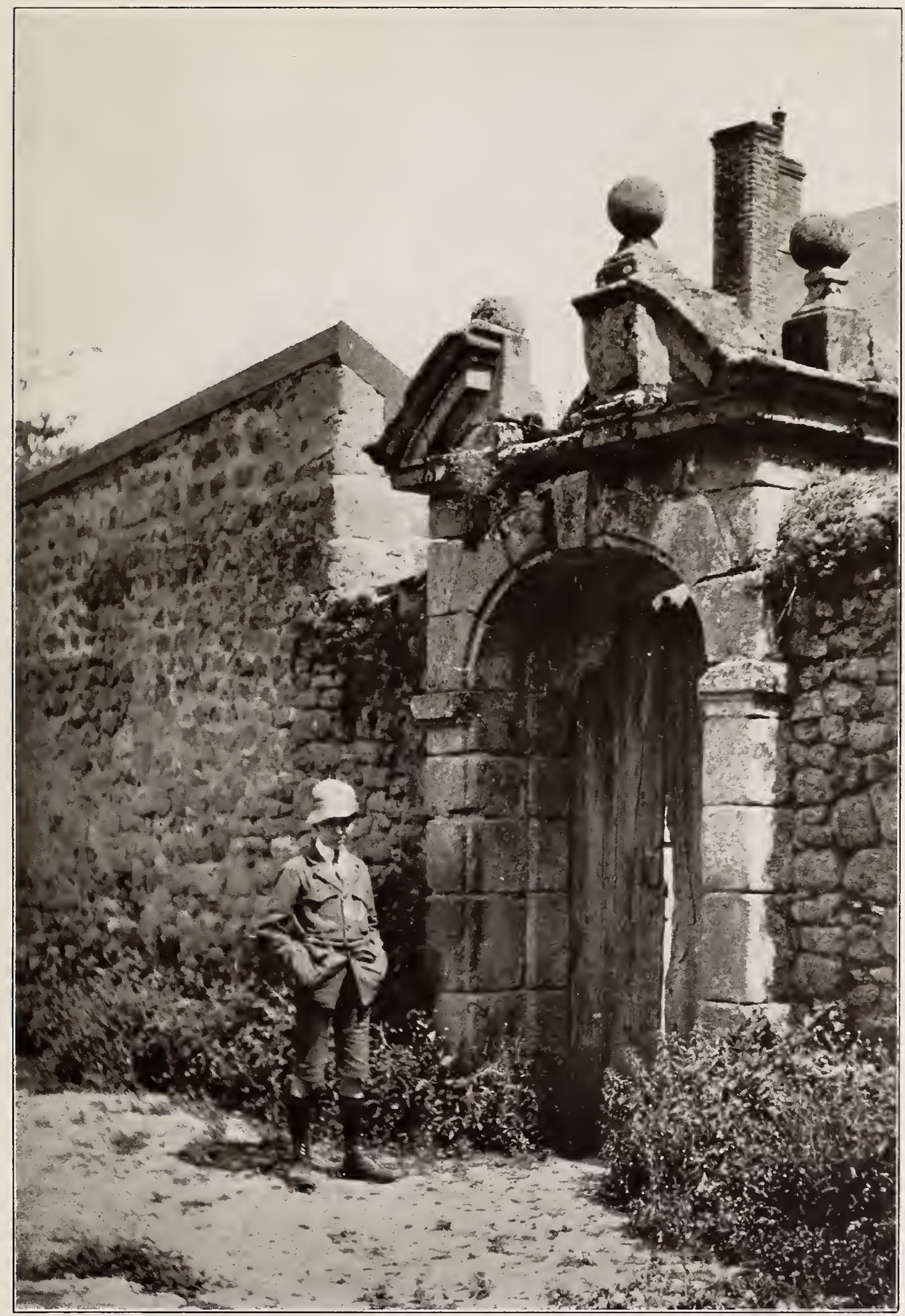

Plate 180. Detail of stone garden-gate of house at Brion, Saône-et-Loire 



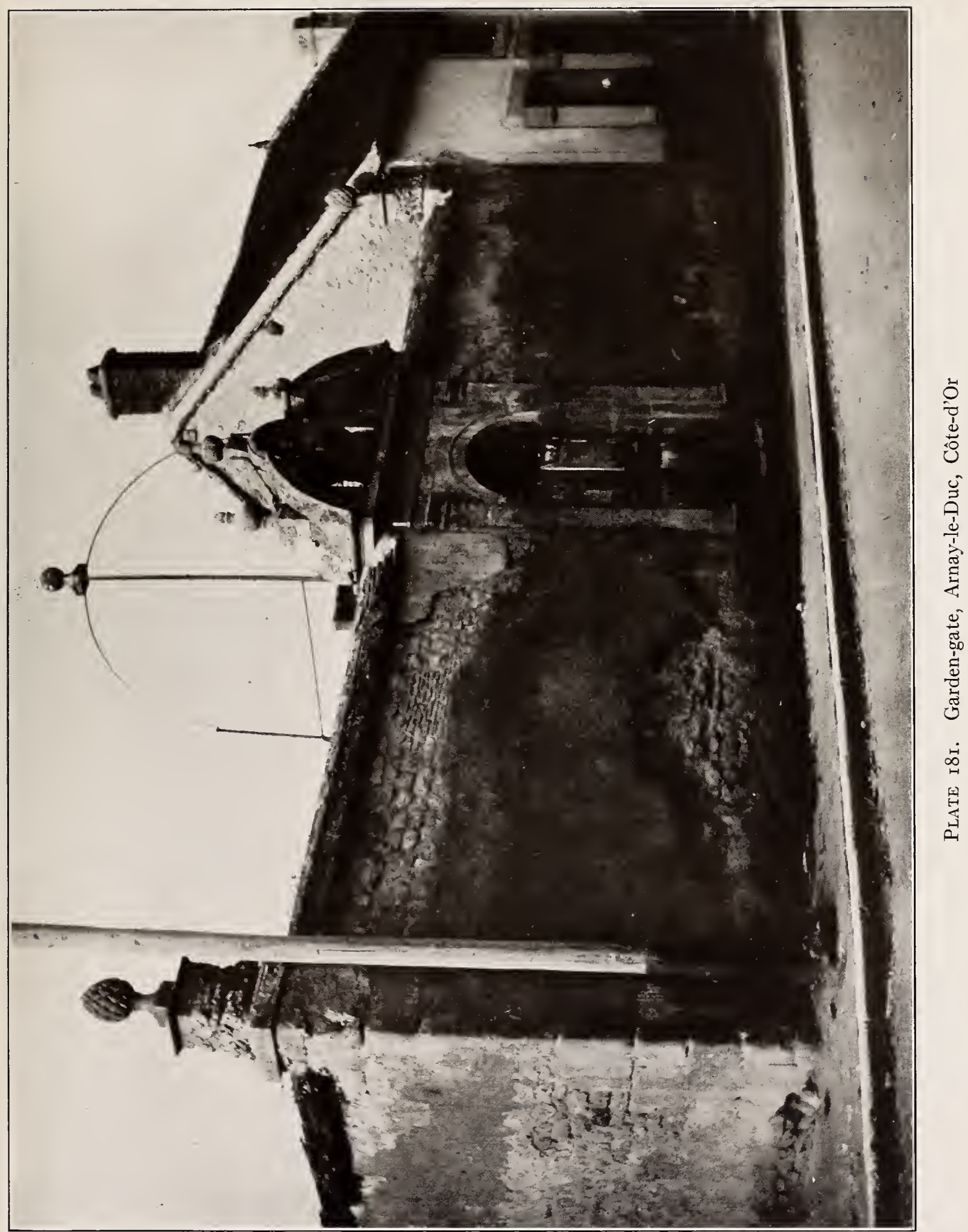





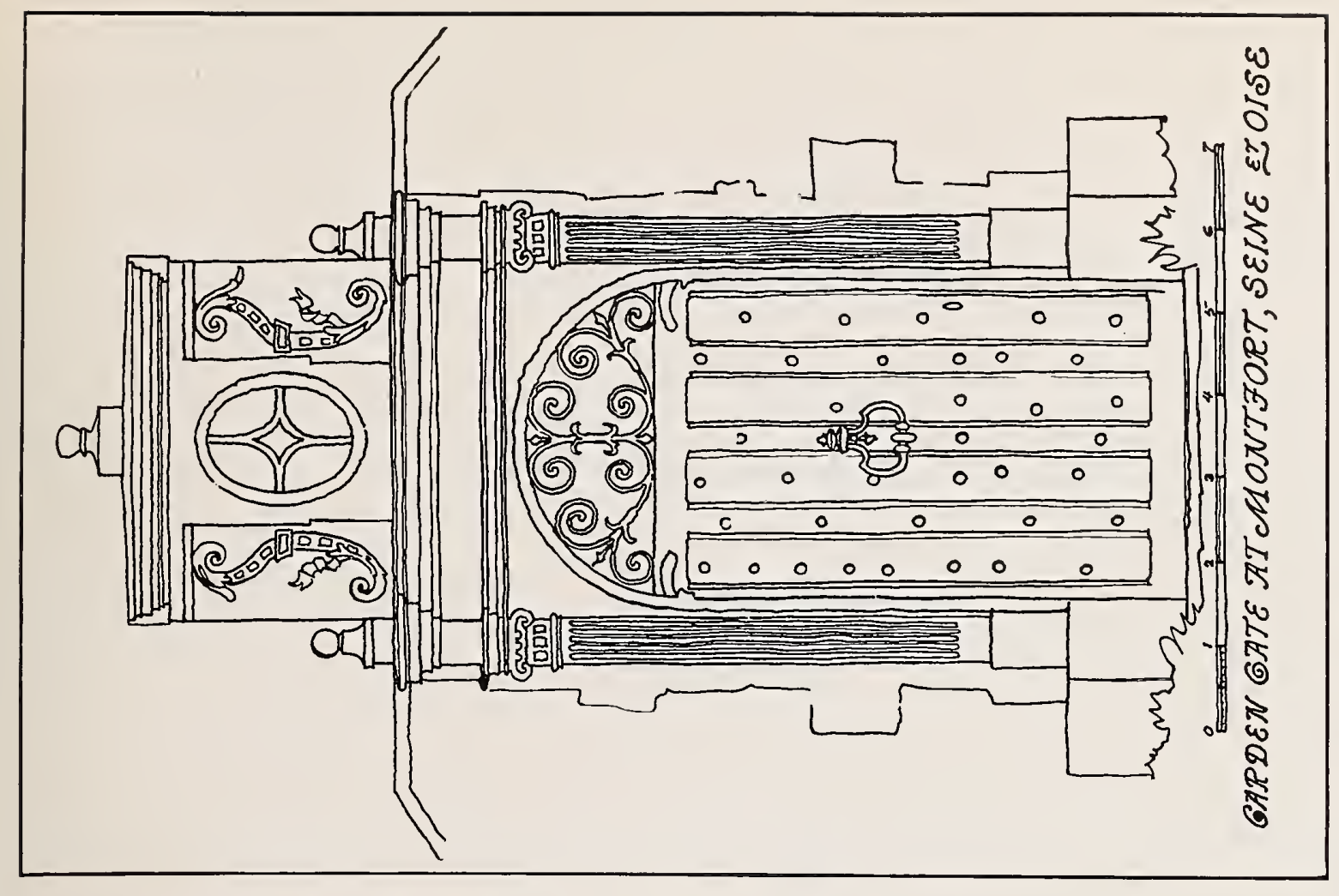



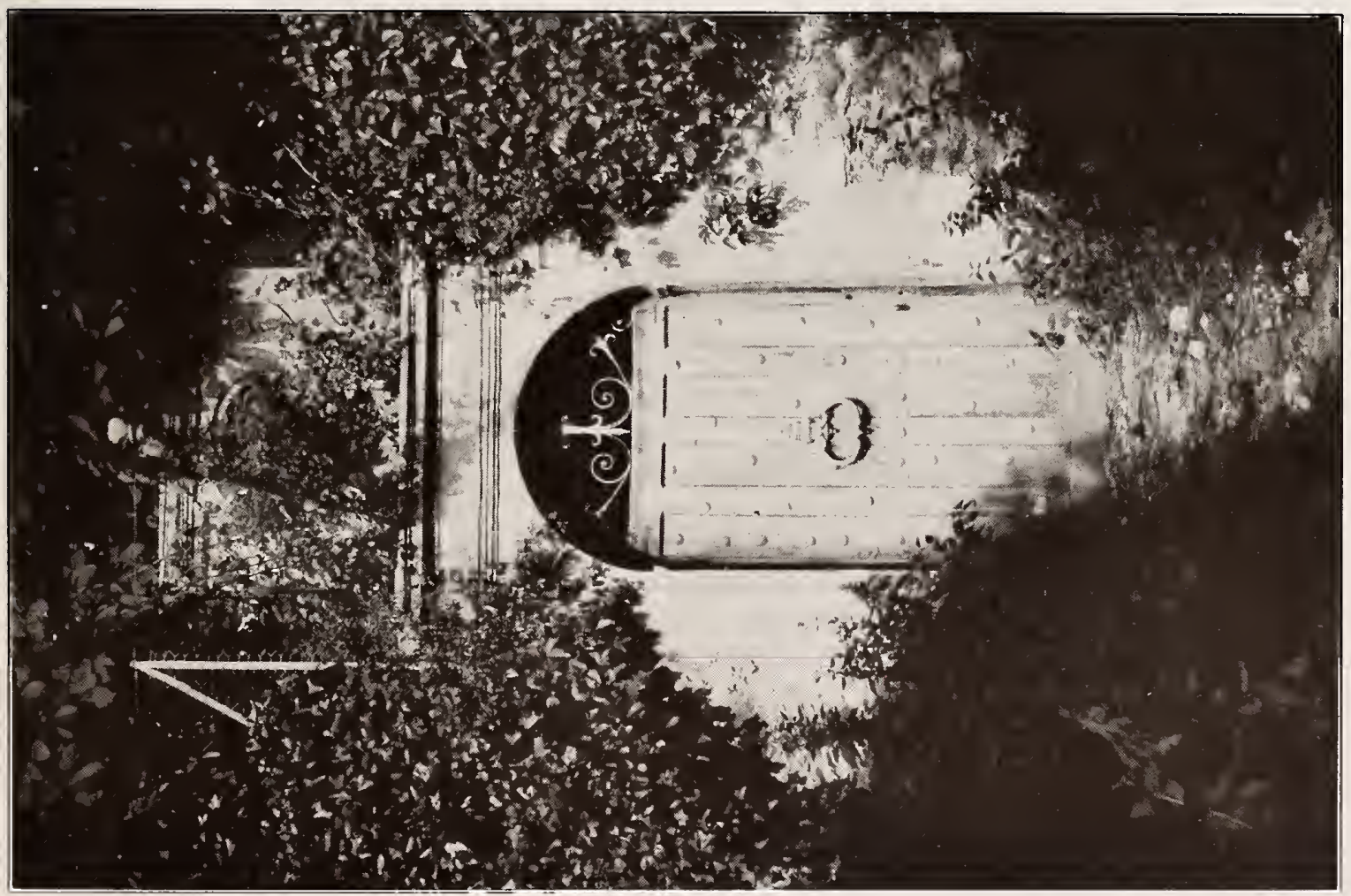





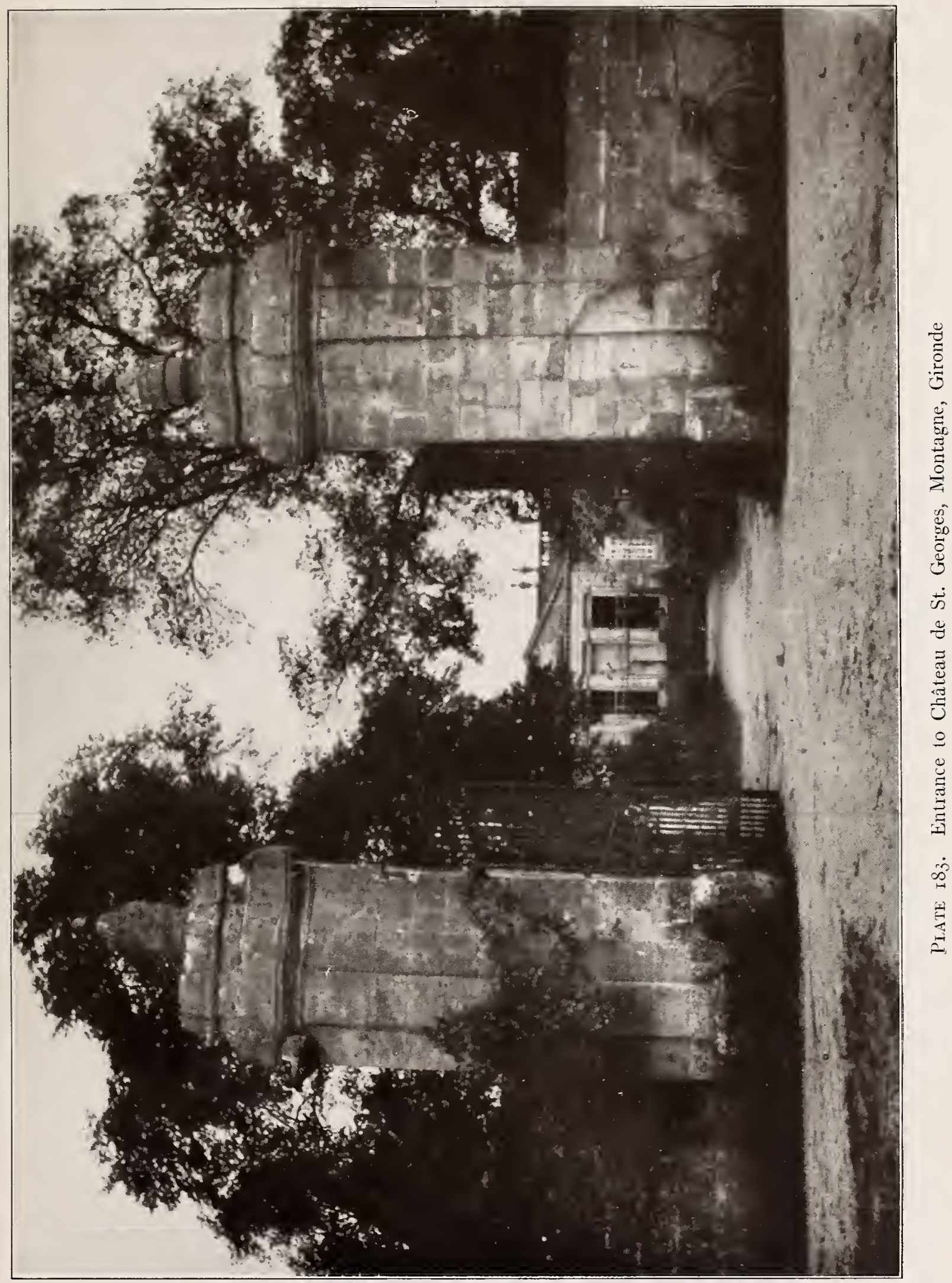




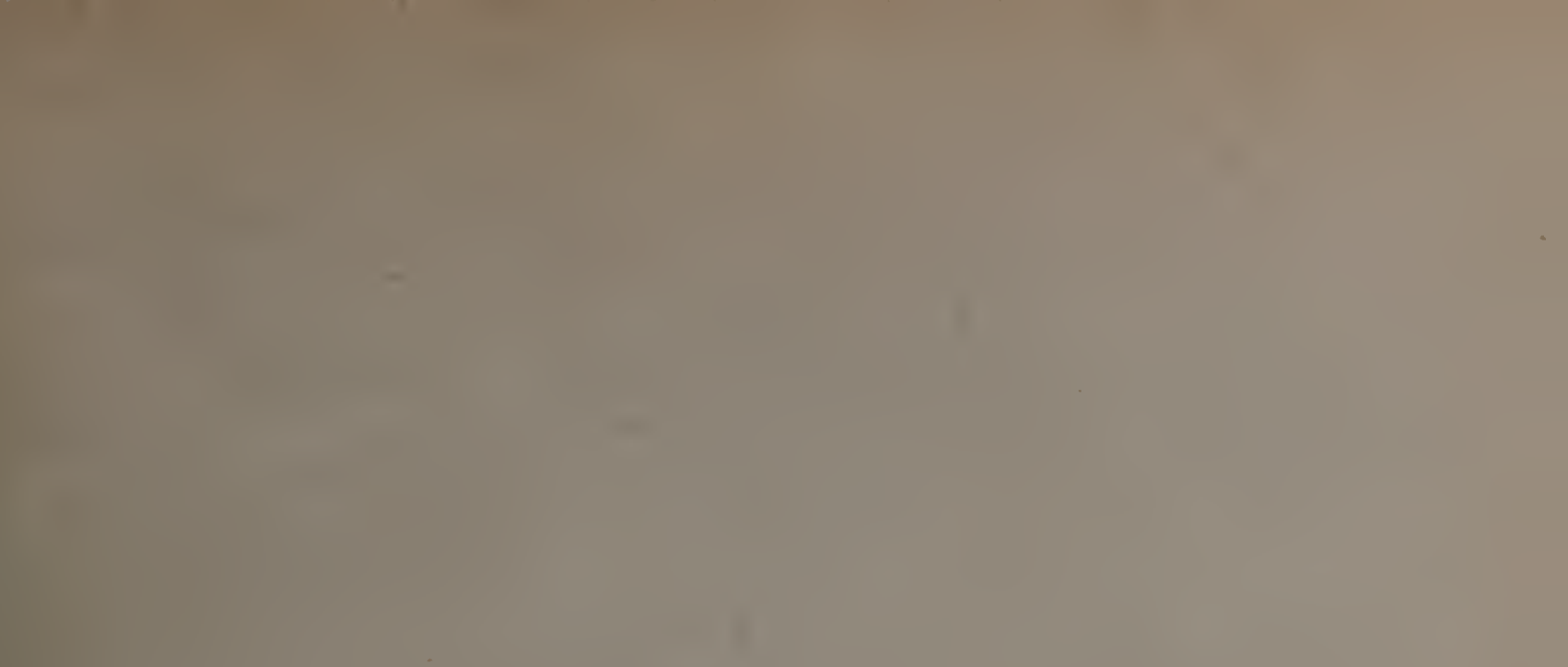

1

7

$\frac{1}{4}+\frac{1}{4}=$

1

나난

$-1=$ 


